University of Louisville

ThinkIR: The University of Louisville's Institutional Repository

Electronic Theses and Dissertations

$12-2018$

\title{
Frederic Lindley Morgan : gentleman architect and reluctant modernist.
}

Lisa Grace Carpenter

University of Louisville

Follow this and additional works at: https://ir.library.louisville.edu/etd

Part of the Architectural History and Criticism Commons

\section{Recommended Citation}

Carpenter, Lisa Grace, "Frederic Lindley Morgan : gentleman architect and reluctant modernist." (2018). Electronic Theses and Dissertations. Paper 3071.

https://doi.org/10.18297/etd/3071

This Doctoral Dissertation is brought to you for free and open access by ThinkIR: The University of Louisville's Institutional Repository. It has been accepted for inclusion in Electronic Theses and Dissertations by an authorized administrator of ThinkIR: The University of Louisville's Institutional Repository. This title appears here courtesy of the author, who has retained all other copyrights. For more information, please contact thinkir@louisville.edu. 
FREDERIC LINDLEY MORGAN: GENTLEMAN ARCHITECT AND RELUCTANT MODERNIST

\author{
By \\ Lisa Grace Carpenter \\ B.A., University of Kentucky, 1992 \\ M.A., University of Louisville, 1996 \\ M.A.T., University of the Cumberlands, 2013
}

\author{
A Dissertation \\ Submitted to the Faculty of the \\ College of Arts and Sciences \\ in Partial Fulfillment of the Requirements \\ for the Degree of
}

Doctor of Philosophy in Art History

\author{
Department of Art History \\ University of Louisville \\ Louisville, Kentucky
}

December 2018 

FREDERIC LINDLEY MORGAN: GENTLEMAN ARCHITECT AND RELUCTANT MODERNIST

\section{By}

Lisa Grace Carpenter

B.A., University of Kentucky, 1992

M.A., University of Louisville, 1996

M.A.T., University of the Cumberlands, 2013

A Dissertation Approved on

December 7, 2018

by the Following Dissertation Committee:

Dr. Rod Miller, Co-Chair

Dr. Christopher Fulton, Co-Chair

Dr. Stephanie Maloney

Dr. Thomas Owen

Mr. Glen Buckner, AIA 


\section{ACKNOWLEDGMENTS}

The author offers her sincere gratitude to Mary Margaret Bell and the Jefferson County Public School Archivists, The Margaret Bridwell Art Librarians, Janice Blair, the University of Louisville Ekstrom Library Special Collections Librarians, Mike Basham at The Louisville Collegiate School, Marty Perry at the Kentucky Heritage Council, Johnna Picco at the Filson Historical Society, and the Louisville Metro Housing Authority.

Special thanks to Winfrey Blackburn for sharing his files and to Dr. William Morgan for his endless patience and unwaivering encouragement to his former student. The author is forever indebted to Dr. Rod Miller for agreeing to serve as dissertation advisor. Much gratitude goes to the Allen R. Hite Art Institute at the University of Louisville for allowing the author to complete her dissertation after a long hiatus, and for awarding her the Morgan fund to finance her education.

To Stephen Pudlo and our four beautiful children for their patience and

understanding throughout this lengthy project. To Jack, Dorothy and Grace-always with me in spirit, and wonderful role models. 


\section{ABSTRACT \\ FREDERICK LINDLEY MORGAN: GENTLEMAN ARCHITECT AND RELUCTANT MODERNIST}

\section{Lisa Grace Carpenter}

December 7, 2018

Frederic Lindley Morgan, a major architect in Louisville, Kentucky, was born in Loda, Illinois in 1889. Morgan, in partnerships with other architects throughout his career, designed a variety of projects including homes, schools, churches, commercial buildings and even an airport. Morgan worked up until he died, in 1970, in Louisville.

What makes Mr. Morgan's work distinctive is not the timelessness of his designs, nor the fact he was dubbed "Louisville's society architect," nor his lengthy 50 plus year career. Morgan had the ability to take his training, in combination with his talent and savvy business sense, and work successfully in a variety of styles - from Classic Revival to Modern. He associated himself with many aspects of the architectural process such as the floor plans, renderings, specifications, interior and exterior finishes, and even furnishings upon occasion. His expertise in Historic Renovation and Preservation involved him in projects such as Old Fort Harrod reconstruction in Harrodsburg, Kentucky, and the renovation of the Locust Grove plantation.

In addition to documenting Morgan's early life and education, major projects such as schools, churches, libraries and clubs, plus a catalogue of his works, other issues will be examined. The impetus behind some of his designs, how they fit into the larger 
scheme of American architecture in the 1900s, and what gives them timeless appeal are also analyzed. 
TABLE OF CONTENTS

PAGE

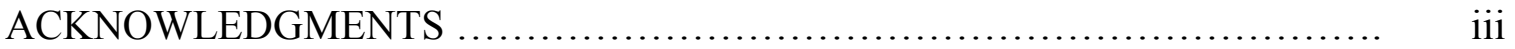

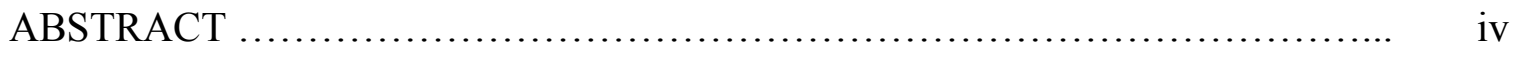

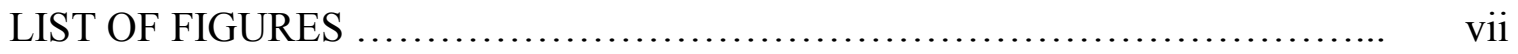

CHAPTER

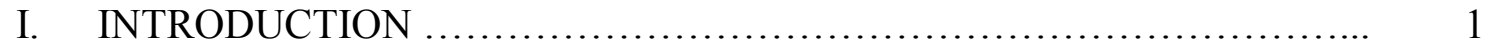

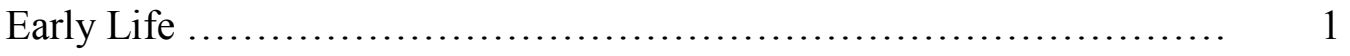

Louisville Years .............................................. 4

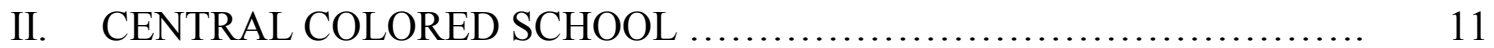

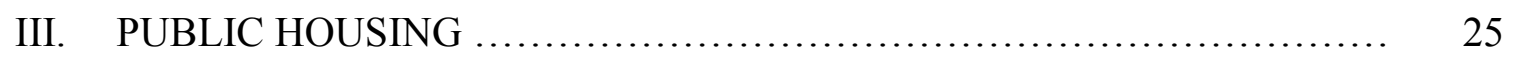

IV. NEW DEMANDS IN EDUCATION: LIBRARY FOR THE UNIVERSITY

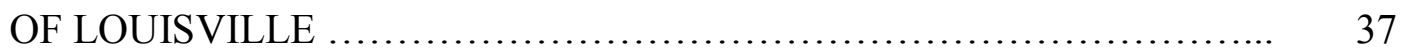

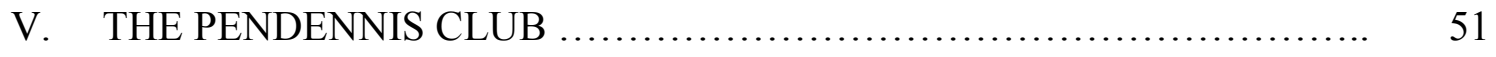

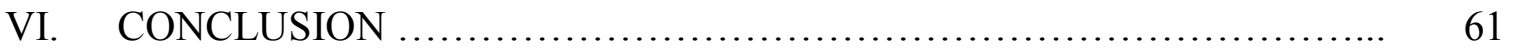

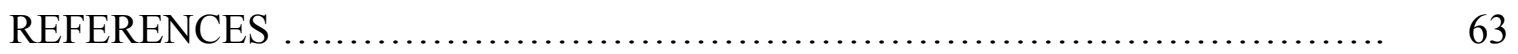

APPENDIX I: CATALOG OF MORGAN WORKS $\ldots \ldots \ldots \ldots \ldots \ldots \ldots \ldots \ldots \ldots \ldots . \ldots \ldots$

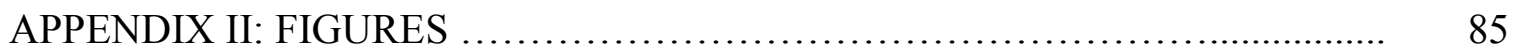

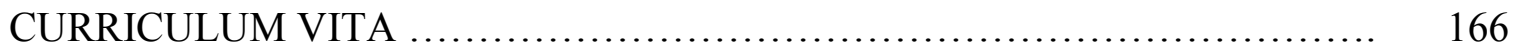




\section{LIST OF FIGURES}

FIGURE PAGE

1. Frederic Lindley Morgan ......................................... 85

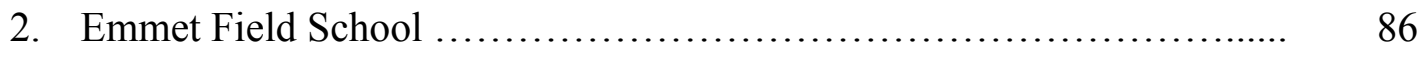

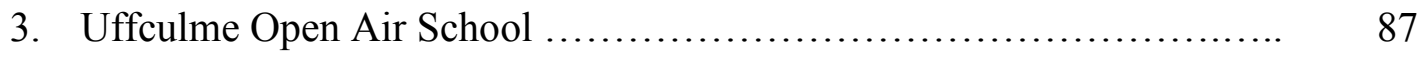

4. Louisville Male High School .................................. 88

5. DuPont Manual High School .................................. 89

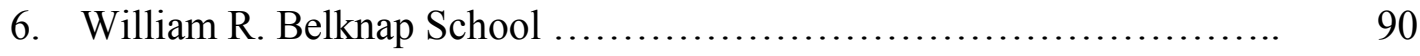

7. Doorknob Detail, William R. Belknap School ...................... 91

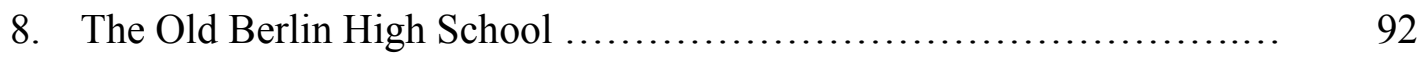

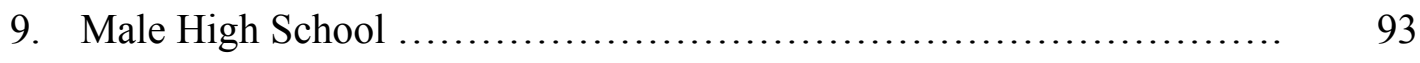

10. New Central Colored School .................................... 94

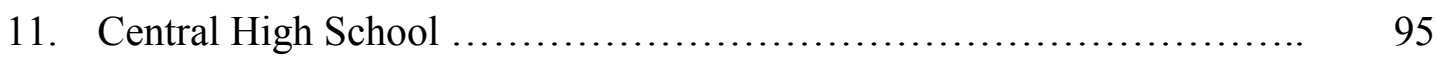

12. Central High School ........................................... 96

13. Louisville Collegiate School .................................. 97

14. Louisville Collegiate School ................................... 98

15. Louisville Collegiate School $\ldots \ldots \ldots \ldots \ldots \ldots \ldots \ldots \ldots \ldots \ldots \ldots \ldots \ldots \ldots . \ldots \ldots$

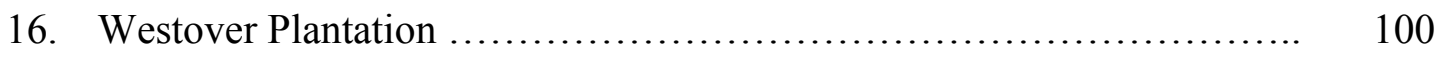

17. Derby House .............................................. 101

18. J. B. McFerran School addition ................................ 102 


\section{LIST OF FIGURES (continued)}

FIGURE

PAGE

19. J. B. McFerran School ......................................... 103

20. Kester Street Elementary School ................................ 104

21. Typical 1950s School ......................................... 105

22. Industrial Revolution Housing ................................ 106

23. New York Boarding House in 1889 .............................. 107

24. Housing at 731 Marshall Street ................................ 108

25. Clarksdale Housing Birds-Eye View ............................ 109

26. Clarksdale Housing Project .................................. 110

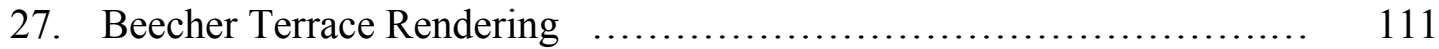

28. Beecher Terrace Overview ..................................... 112

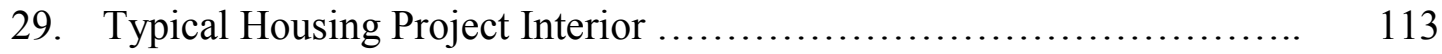

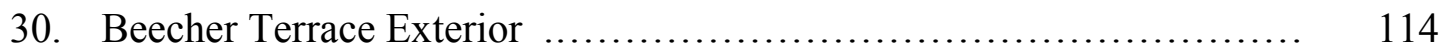

31. Beecher Terrace Elevation ..................................... 115

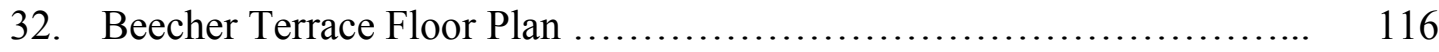

33. Techwood Homes ................................................. 117

34. Tasker Homes ................................................. 118

35. Pruitt-Igoe Housing Project ................................... 119

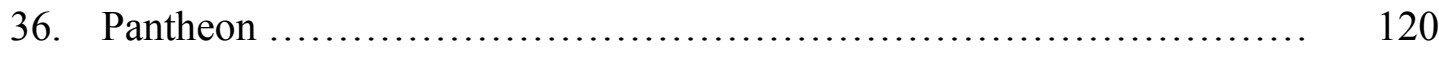

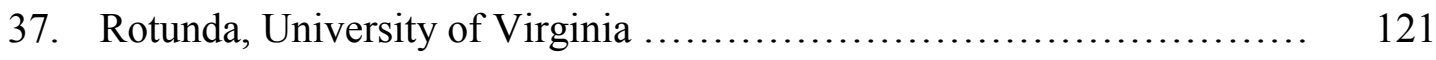

38. Villa Rotunda (Villa Capra) ...................................... 122

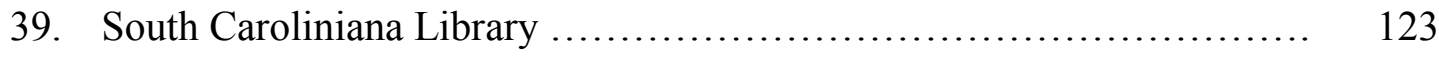




\section{LIST OF FIGURES (continued)}

\section{FIGURE}

PAGE

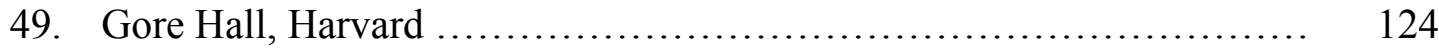

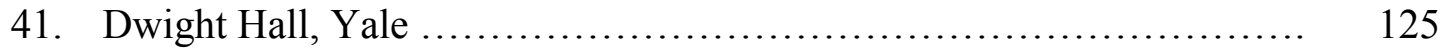

42. King's College Chapel, Cambridge ............................... 126

43. Administration Building, University of Louisville ................... 127

44. Monticello ...................................................... 128

45. Law Library, Columbia University ............................... 129

46. Gould Memorial Library ..................................... 130

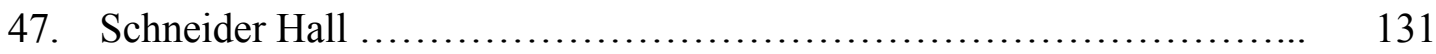

48. Schneider Hall ................................................... 132

49. Schneider Hall ............................................... 133

50. Schneider Hall ............................................... 134

51. Schneider Hall ............................................... 135

52. Lee Terminal ............................................... 136

53. Methodist Episcopal Hospital .................................. 137

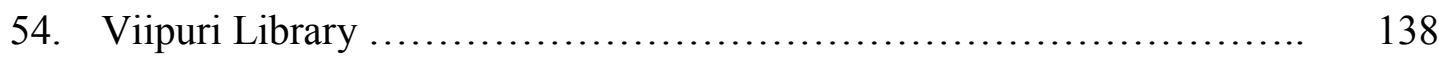

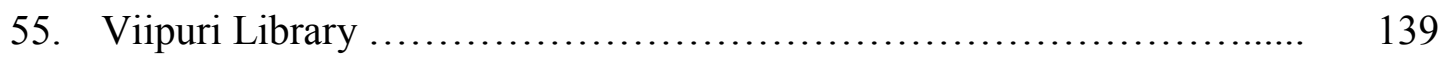

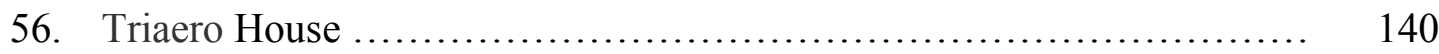

57. Hunt-Belknap Residence ....................................... 141

58. Pendennis Club .............................................. 142

59. Pendennis Club ............................................ 143

60. Pendennis Club ................................................. 144 


\section{LIST OF FIGURES (continued)}

FIGURE

PAGE

61. Pendennis Club ............................................. 145

62. Pendennis Club ............................................... 146

63. Pendennis Club .............................................. 147

64. Pendennis Club ................................................ 148

65. Pendennis Club ............................................... 149

66. Pendennis Club ............................................... 150

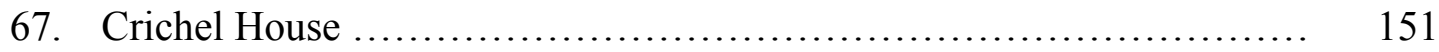

68. Pendennis Club ........................................... 152

69. Pendennis Club ................................................. 153

70. Pendennis Club............................................... 154

71. Pendennis Club............................................... 155

72. Pendennis Club................................................ 156

73. Pendennis Club............................................... 157

74. Pendennis Club.............................................. 158

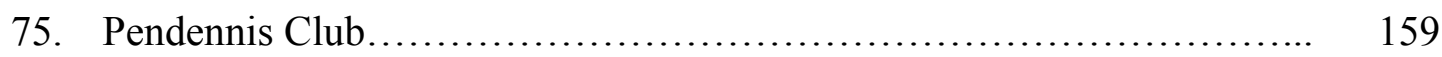

76. Columbia Club ................................................ 160

77. Knickerbocker Club .......................................... 161

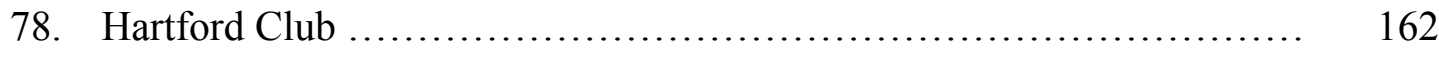

79. Schuster Building ........................................... 163

80. New Alumni Chapel .......................................... 164

81. Church at Old Sturbridge Village $\ldots \ldots \ldots \ldots \ldots \ldots \ldots \ldots \ldots \ldots \ldots \ldots \ldots \ldots \ldots \ldots$ 


\section{CHAPTER I}

\section{INTRODUCTION}

When one strolls the grounds of the Drumanard estate, situated on 50 sprawling acres outside of Louisville, Kentucky, images of a time gone by come to mind. Built in the 1920s, one can imagine the lavish parties held at this glorious venue. The architect of the 10,000 square-foot home, Frederic Lindley Morgan, was Louisville's society architect, welcomed into the elitist social group of the river town's chosen few. One would imagine that he was born and bred into this social niche, as so many were, since he had so many loyal client friends. The man, though, still keeps his public guessing, almost a half a century after his passing, as his life and his work were a series of contrasts.

\section{$\underline{\text { Early Life }}$}

Born in the sleepy Midwest town of Loda, Illinois in 1889, Frederic Lindley Morgan would have had limited architecture experiences in his youth. His exposures would have included the vernacular architecture of his town, books, and journals. Had he been fortunate enough to visit Chicago, he would have witnessed a rapid building program with firms like Burnham and Root and Adler and Sullivan leading the way.

When as a young man studying at the University of Illinois, he was immersed in a traditional program modeled after the Beaux-Arts methodology. His love of traditional

designs, meticulous attention to details, and uncompromising standards of quality, began 
at the place he would later call his alma mater. This is evident even in his early plans for a library. Following graduation in 1913, Morgan embarked on a prolonged architectural tour of Europe (England, France, and Italy) with a group of his fellow University comrades. ${ }^{1}$ The tour guide was his professor, Newton Alonso Wells (1852-1923). An American painter, Wells completed four murals at the University of Illinois. ${ }^{2}$ The university was so impressed with him personally and professionally that they hired him as a professor of Architectural Decoration. Beloved by his students, they dedicated their first architectural journal to him, of which Morgan was a staff member. ${ }^{3}$ The relationship between the professor and student would prove influential. Morgan developed a professional reputation in his renderings and detailed sketches, some of which are still accessible through his notes and drawings he donated to the University of Louisville. ${ }^{4,5}$

In 1915, Louisville architect Earl Henry contacted the University of Illinois looking for a draftsman. Home from Europe, Morgan took the position and relocated. Under Henry's tutelage, he designed instructional buildings for about two years, as the former was under contract with the Jefferson County School Board. ${ }^{6}$ This was the naissance of a long and profitable career in institutional architecture.

One of the projects most likely worked on during his first tenure with Henry was the Louisville Male High School (1915). Established in 1856 as a preparatory school for

\footnotetext{
${ }^{1}$ The time frame for the tour is given as three months in some sources and eighteen months in others.

${ }^{2}$ www.archives.syr.edu/collections/fac-staff/sua_wella_n.htm.

${ }^{3}$ University of Illinois Architectural Journal.

${ }^{4}$ Frederic Lindley Morgan file, American Institute of Architects, letter dated 22 Sept 1948 from Fred Elswick to Jury of AIA fellows. Elswick states "I have known Fred for twenty-two years. Back in our post-youth of artistic inspiration and professional ambition as a furtherance of our education, we went on outdoor sketching expeditions. Fred, to my envy, could apply to smooth paper ... a few lines . . and gain the ultimate by "representation without pictorialization, as taught by the recognized delineators of that era." ${ }^{5}$ University of Louisville Frederic Lindley Morgan archives in Art Library special collections.

${ }^{6}$ American School Board Journal, vol. 60, p. 76.
} 
young men, there have been four building sites constructed to date for the school. The one during Henry's tenure served as the school's home for over 75 years. ${ }^{7}$

Around the inception of World War I, Morgan lived and worked in Detroit. The documentation of many of the service records for the Great War have been destroyed, hence the only form located was the exemption from service due to caregiving responsibilities for his mother. ${ }^{8,9}$ This immunity allowed Morgan to work for two different firms while in Detroit. The first was similar to the position he held with Earl Henry, designing institutional buildings for the Detroit Board of Education's architectural firm, Malcolmson and Higginbotham. ${ }^{10}$

Morgan's next career endeavor landed him as a draftsman at the Detroit firm of Smith, Hinchman, and Grylls, one of the oldest architectural firms still operating in the United States. ${ }^{11}$ By 1906, the firm had achieved recognition not only for its architecture, but also for its cutting-edge engineering department noted for experimentation with contemporary materials. Morgan stayed at the firm, which boasted 270 employees, for almost three years, through the close of the First World War. The valuable experience Morgan garnered from Smith, Hinchman, and Grylls would show its visible presence in his selection of methods and materials throughout his career.

A permanent move to Kentucky took place in 1919, when Earl Henry contacted him to join the firm Henry had established with Hugh Nevin. Morgan's role would be as

\footnotetext{
7 "Louisville Male High School" Encyclopedia of Louisville, p. 558.

${ }^{8}$ Some autobiographical information written for Who's Who and other like publications claim service in the Army.

${ }^{9}$ Frederic Lindley Morgan World War I service application.

${ }^{10}$ Between 1895 and 1923 , this firm is noted for designing approximately $75 \%$ of the educational buildings located in Detroit. Some of their more notable commissions included buildings on the college campuses of Wayne State University (1895), East Michigan University (1896), and the University of Michigan (1905). See www.wikipedia.com.

${ }^{11}$ Sheldon Smith opened the firm in 1855. See Michigan Modern.
} 
designer. A few months after he began working, Earl Henry passed away unexpectedly. Morgan was promoted to full partner in the firm where he would remain until his death. Hugh Lloyd Nevin (1876-1969) began his career as a plumbing and heating contractor. ${ }^{12}$ Nevin then attended law school. After passing the Kentucky Bar Exam, he decided to work as an architect. His company "Nevin Homes" profited from his strength in networking and promotion. His connections with the Presbyterian Church and Centre College would prove very rewarding for the firm. ${ }^{13}$ Morgan, with his creativity and skill, and Nevin, with his business savvy and marketing knowledge, proved a successful working relationship, and would remain business partners until Nevin's retirement in 1965.

\section{Louisville Years}

When Morgan relocated to Louisville, the city was in the midst of growth and expansion. In Cities in the Commonwealth, the author states, "By 1885 an estimated 22,000 operatives worked in some 1,300 manufacturing establishments and annually produced goods valued at $\$ 50$ million. Pork packing, tobacco manufacturing, and whiskey distilling remained the city's leading industries ...." ${ }^{14}$ Louisville's proximity to both the Ohio River and the railways made it an ideal locale for industry.

Fortunately, for Morgan, the 1920s brought financial stability. His mother passed away in 1919. As an only child, he received an inheritance that would assist in providing a comfortable lifestyle for the remainder of his life. Morgan's father, who died in 1895,

\footnotetext{
${ }^{12}$ Fellow architect Stratton O. Hammon nicknamed Nevin "the Plumber." Taped interview between Sam Thomas and Julie Weber Nopper (8-21-1995) from Sam Thomas Files, University of Louisville archives. ${ }^{13}$ According to Sam Thomas, in Cherokee Triangle, Nevin was a "trustee of Centre College, president of the Pendennis and Juniper Clubs, a church deacon and elder ... (and) had the necessary connections to make the firm successful," p. 77.

${ }^{14}$ Allen Share, Cities in the Commonwealth, p. 76.
} 
was a pharmacist in Loda, Illinois. When Maud Morgan's estate was settled, Morgan inherited the pharmacy building in Loda, plus property in Champaign County, Illinois. ${ }^{15}$ Fellow Louisville architect Stratton O. Hammon (1904-1997), would later comment on him as a

timid little man but stubborn and determined. He was the only architect that I knew who had an independent income and thus did not have to rely so completely, as did others, on the fees he received from his clients. He used this advantage to "Jockey" his clients into accepting most of his ideas rather than their own, and this was all to the good. ${ }^{16}$

Morgan was building a reputation for himself as a talented architect. The bonds that he forged during his younger days with Louisville's wealthy elite would prove to be profitable for him, and he remained a popular houseguest at social gatherings and events. In the History of Kentucky (1922) entry on Morgan, it states "although young in years, he has advanced far in his profession and a winning personality has drawn him to a large circle of steadfast friends."17

Professionally, Morgan applied and was approved for membership into the Kentucky Chapter of the American Institute of Architects in 1921, of which he would remain a member until his death. His nomination form stated

Ever since the death of Earl Henry, Fred has been the firm member responsible for the design of their work. Fred is himself an excellent draftsman, equally adept in pencil or color. All designs, whether for large or small work originate on his board in sketch form before they are turned over to the drafting room for working drawings. ${ }^{18}$

In the early 1920s, the firm designed a string of churches in the Kentuckiana area and beyond. Nevin and Morgan were both members of Highland Presbyterian Church in

\footnotetext{
${ }^{15}$ Estate papers of Maud Lindley. Frank Lindley, Maud's brother and an attorney, handled the estate.

${ }^{16}$ Stratton Hammon, "The Story of a House," 1989, p. 2. Unpublished Paper.

${ }^{17}$ History of Kentucky, Volume IV, p. 718, entry on Frederic Lindley Morgan.

${ }^{18}$ AIA Nomination form for Fellowship by Chapter From, 16 September 1948, pp. 2-3.
} 
Louisville, and the firm would complete many church designs, additions, and renovations over the next 40 years, many of them Presbyterian, and many traditional in design.

In the mid-1920s, Morgan would embark on a project that many consider his swan song. Founded in 1881, the Pendennis Club is a private social club exclusively for men, located in downtown Louisville. Still in operation today, the façade looks very similar to when it was first constructed. Architect Stratton Hammon called the Pendennis Club "one of the two finest twentieth century buildings in Kentucky."19

In 1920, Herman Wischmeyer (1875-1945) joined the firm and stayed for eight years. ${ }^{20}$ An article published in the Courier-Journal in 1922 discussed how architectural firms were the busiest in their history. The article stated that

the firm of Nevin, Wischmeyer, and Morgan had an unprecedented amount of work on hand. It has been preparing plans for nine churches, the New Home Telephone Company Branch Exchange, new Barracks for the Kentucky Military Institute in Lyndon, an addition to the Negro Girls High School in Louisville, various construction projects for the State Board of Charities and Corrections, and designs for the A. T. Hert Memorial Bridge. ${ }^{21}$

By this time had also developed a reputation as a historic preservation/restoration expert. In 1925 he was appointed chairman of the Kentucky Chapter of the American Institute of Architects' committee established to survey the state's historic architecture. ${ }^{22}$ In 1927, Morgan played a principal role in the recreation of Fort Harrod, in Harrodsburg, Kentucky, at Old Fort Harrod State Park. A drawing by W.W. Stephenson, a politician from Kentucky, Harrodsburg native, and founder of the Harrodsburg Historical Society, served as the inspiration for Morgan's plan and renderings. The important role of Fort

\footnotetext{
${ }^{19}$ See Stratton Hammon, "The Story of a House," p. 1.

${ }^{20}$ Wischmeyer left the firm to join William Arrasmith. Wischmeyer, Arrasmith, and Louisville architect Fred Elswick (joined firm in 1936) would design the notorious Greyhound Bus terminals. See Frank E. Wrenick, The Streamline Era Greyhound Terminal, p. 53.

${ }^{21}$ The Courier-Journal, Sunday, 11 June 1922, p. 37.

${ }^{22}$ Notes from Sam Thomas lecture on Frederic Lindley Morgan, Filson Club Historical Society, 24 September 1995, p. 3.
} 
Harrod was twofold: to serve as the visual representation of the Kentucky frontier in the 1700 s, and to commemorate the hardships the settlers endured to establish the community that evolved into Harrodsburg. ${ }^{23}$

Several more restorations and historical reconstructions would land on Morgan's drafting board throughout his career, including President Zachary Taylor's boyhood home, 'Springfield,' President Lincoln's parents' home, and the Georgian Locust Grove plantation, which went through a major renovation/restoration in the 1960s. Morgan was the supervisor of the project and prepared working drawings for the reconstruction. ${ }^{24}$

$$
\text { Around } 1930 \text { architect Joseph Hyde Kolbrook }{ }^{25} \text { (1891-1976) partnered with }
$$

Nevin and Morgan. His tenure would last about a decade and a half. The J. B. Speed Art Museum in Louisville held a showcase of local architects' work from February 1-15, 1931. The exhibition consisted of boards with blueprints and renderings of recent and more notable commissions. This was a positive way to generate interest in the trade during lean years, since the building boom of the mid-1920s had come to a standstill. The firm of Nevin, Morgan, and Kolbrook's impressive display included four residences, two schools, and the Fort Harrod project. ${ }^{26}$

In 1933, President Roosevelt's New Deal enacted the Works Progress Administration (WPA) to employ many of those left jobless by the Great Depression. An agency under the WPA was the Historic American Buildings Survey (HABS). Morgan was appointed to the District Advisory Committee in 1934. Ever the preservationist at

\footnotetext{
${ }^{23}$ Sam Thomas Files, U of Louisville archives; www.parks.ky.gov; www.kyhistory.pastperfectonline.com. ${ }^{24}$ Grove Gazette, Winter 2007, "Morgan, considered Kentucky's foremost designer in Georgian Revival and Federal styles, prepared the restoration drawings and supervised the work at Locust Grove."

${ }^{25}$ Nee Joseph Hyde Kaltenbach.

${ }^{26}$ The J. B. Speed Memorial Museum, Louisville, Kentucky Exhibition by Architects of Louisville, Kentucky, 1-15 February 1931, Exhibition Catalogue.
} 
heart, he was quoted in a newspaper asserting "a most decided interest is developing in both old homes and old business buildings."27

The mid- to late-1930s saw the US economy begin to bounce back from the Great Depression. In Makers of Modern Architecture, author Martin Filler concludes even now, an architect still needs a client before a project can proceed. . . I see a recurrent theme ... of the decisive role that personality, character, and temperament play in shaping architectural careers. Larger forces beyond the control of any person - the economy, war, nationalism, political instability, natural disasters - determine cycles of construction as much as anything else. Yet the ways in which an architect, even the most creatively endowed, is able to cope with external pressures can make all the difference. ${ }^{28}$

Frederic was wise enough to apply his talents to any job he was offered, which is one reason why his catalogue of works is so large. He was noted for his talent in residential architecture, of which he designed at least 75 homes during his career. The bulk of these were completed from the 1920s to the 1940s. Renovations and additions took place in the years following, or some patrons simply moved and had Morgan build them something new. By the close of the Second World War, the traditional styles of Morgan's youth were considered old-fashioned and outdated. The Modern Movementwith its new choice of materials, styles, and specifications - was here to stay.

Fortunately, Morgan was adept in designing in the Modern Style and had completed several commissions, beginning in the late 1920s. His days at Smith, Hinchman, and Grylls and the experience he gained in using new materials paid off. The James Dabney Laboratory (Jones-Dabney Company) was built in 1935 not far from the Portland area of Louisville. This stark white Art Deco building "might be the very first site-built, slip-formed poured concrete building in the United States. The unique façade

\footnotetext{
${ }^{27}$ Sam Thomas lecture, FIlson Club Historical Society, 24 September 1995, p. 3.

${ }^{28}$ Martin Filler. Makers of Modern Architecture. New York: New York Review of Books, 2007, p. xvi.
} 
is notable for a streamlined profile, curved corners and accents, and horizontally-oriented windows. ${ }^{29}$ Another Modern structure is the WHAS Radio Transmitter Building, completed by the firm in 1928. This Classic Revival structure contains elements of Art Deco and Egyptian Revival. Unfortunately, for him, this myriad of styles resulted in a choppy finished project, and not nearly as successful architecturally as some of his other works. Morgan's firm, though, would continue with Modern commissions throughout the rest of his career. The architect, though, never lost his traditional roots.

Walter Creese (1919-2002), Professor Emeritus at the University of Illinois who taught at the University of Louisville early in his career, penned a letter to Professor William Morgan in $1994 .{ }^{30} \mathrm{He}$ wrote:

On being an urbaniste, Fred once pointed out to me that he had done the reinforced concrete parking garage for Stewart's downtown store: "They thought I couldn't do it because it was too utilitarian, unaesthetic!" For a long while after I'd ask people if they knew Fred had done the garage, and they'd say "no." Fred was quite a person - modest, careful, and conscientious, and a real lover of the arts. Early on I thought I had discovered an eighteenth century Louisville house that wasn't in the books. I asked him at the Arts Club one evening whether he knew the house, that might be eighteenth century, and he began to laugh, as he had designed it. ${ }^{31}$

Morgan practiced architecture until the end of his life in 1970, at the age of 81.

The majority of his architectural peer group had retired, passed away, or both. He was fortunate to be able to do what he loved, and left a legacy behind that would allow future generations to gain an appreciation of the arts and architecture.

Almost 50 years after his passing, Frederic Lindley Morgan still keeps his audience guessing, as his works were a series of contrasts. He is best remembered for his

\footnotetext{
${ }^{29}$ See www.brokensidewalk.com/2015/jones-dabneybuilding. Unfortunately, this architectural gem is in danger of being razed.

${ }^{30}$ Professor Emeritus William Morgan (1944- ) was Professor of Architectural History at the University of Louisville for 25 years.

${ }^{31}$ Letter from Walter Creese to William Morgan (1944- ), dated 14 May 1994.
} 
traditional designs yet completed a number of significant commissions in the Modern Style. He designed homes for Louisville's social elite yet also worked on the city's public housing projects. He designed one of Louisville's prestigious private schools yet began his career working on public school projects, including the Louisville Colored School. He designed a Modern Library for the University of Louisville yet collaborated on one of the most revered traditional buildings on the same campus decades earlier. He left the bulk of his estate to the University of Louisville, not his alma mater the University of Illinois, when he passed away, so as to endow an architectural college. His greatest gift to present and future generations, though, is his extensive catalog of works, which serve as a testimony to his talent and hard work. 


\section{CHAPTER II}

\section{CENTRAL COLORED SCHOOL}

"Laundry is the only thing that should be separated by color."

--Author Unknown

Earl Henry, a University of Illinois grad who practiced architecture in Louisville, wrote his alma mater looking for a draughtsman. Morgan, back from his European tour and in need of employment, was recommended for the position and relocated to the River City. Although not the most exciting job for the new graduate, it was steady work and good experience. Furthermore, Henry and his partner Brinton Davis had secured a contract with the Louisville Board of Education to build seven schools before $1915 .^{32}$ Morgan was hired at the tail end of the contract and had a hand in the Emmet Field School (1913-1915), the Belknap School (1913-1915) and sections of the Louisville Boys High School (1913-1915).

All projects have their challenges. Educational mandates have been written and revised since they were first put into action and standards are constantly changing. "Schools are influenced by political and social movements, new technologies and trends, the growing awareness of what makes us learn better and thus our notions of what makes

\footnotetext{
32 Jonathan Jeffery. "Brinton Beauregard Davis." The Louisville Encyclopedia, 2001, Lexington: UP of
} Kentucky. 
a great school are constantly shifting and adapting to new ideas." 33 Morgan was hired for his capability in drafting and rendering, along with his familiarity with new methods and materials as a result of his work for the Detroit School Board.

One reason for the need for new educational buildings was the mushrooming population of Louisville in the early twentieth century. After the child labor laws were put into place after 1900, the children who might have previously been laboring on farms or in factories now had a chance to gain a free public education. ${ }^{34}$ Regulations restricting youth under the age of sixteen from employment were passed, and states that manufactured products utilizing child labor were taxed an extra ten percent. ${ }^{35,36}$ Those who were involved in the design and specifications of educational buildings had to place the highest priority on ventilation, heating, air quality, and lighting. The ultimate objective was "safety, permanence and endurance" ${ }^{37}$ while accommodating as many students as possible.

Prior to the close of the nineteenth century, the interior of school buildings bore similar resemblances to factories — somber, crowded, and with poor ventilation. ${ }^{38}$ The exteriors displayed elements of regional architecture, which was also determined by the

\footnotetext{
${ }^{33}$ A History of School Design and Its Indoor Environmental Standards, 1900 to Today, p. 3.

34"Concerns about Kentucky's high level of illiteracy and poverty led to the 1912 legislative provision which mandated attendance for all school children from age 6 to age 16. Progressive educators and lawmakers were deeply worried about the impact of both an undereducated workforce on the state's economy and culture, and about the welfare of small children who were compelled to take employment outside of the home." See Rachel Kennedy and Cynthia Johnson, Kentucky Historic Schools Survey: An Examination of the History and Condition of Kentucky's Older Schools, Kentucky Heritage Council, 2002. ${ }^{35}$ For more information on child labor, see High D. Hindman, Child Labor: An American History. New York: Routledge, 2015.

${ }^{36}$ Before 1908, most students finished their schooling after completing the sixth grade. This mandate instigated the establishment of at least one high school per country by 1910. See Historic American Buildings Survey, p.21.

${ }^{37}$ See A History of School Design and Its Indoor Environmental Standards, 1900 to Today, p. 3.

${ }^{38}$ See A History of School Design and Its Indoor Environmental Standards, 1900 to Today, p. 4.
} 
wealth of the area and the budget for the building. After the school reforms were

enacted, and

prior to 1930 , thoughtfulness and resources went into their construction. Artwork was often crafted into the buildings. Their heavy wall mass served as energy saving insulation. There was always a focus on fresh air and daylight, with high ceilings and large windows. These were some of the first American buildings to incorporate fresh air-enhancing ductwork. The builders seemed to understand the advantages of fresh air, full-spectrum lighting and energy efficiency. Traditional building products were wood, rock and glass. The buildings were usually several stories high, allowing for a more modest footprint and greater window space, with more natural fresh air and less opportunity for roofing failure, water penetration and consequent mold contamination of the ambient air. ${ }^{39}$

Morgan's firm was at the cusp of these innovations, providing the newest and safest technology for students.

Perhaps these technical improvements and aesthetic details to the post 1900 school buildings were a result of more architects receiving training and/or architecture degrees. The formal study of past buildings' failure and successes, along with a deeper understanding of how systems worked in conjunction with one another, led to a higher value placed on these buildings not only for the children that would study inside but also for aesthetic and technological impacts. There were other reasons behind the creation of the new school buildings. Donovan, in School Architecture, wrote that

there is nothing more impressive or hopeful in American democracy than the devotion of the people to education... Unconsciously the spirit has been to represent truly this national devotion to education in the architecture of public schools. One of the important functions of school architecture is to sell education to the public. This is accomplished by making attractive that side of education which the public sees most. ${ }^{40}$

Henry made a very wise decision by hiring Morgan. One of Morgan's strengths was his drawing and rendering ability. It is interesting to note that Henry allowed his

\footnotetext{
${ }^{39}$ See Renaissance of the American School Building, p. 9.

${ }^{40}$ John Joseph Donovan et al., School Architecture, New York: MacMillan, 1921.
} 
new hire the important task of executing the renderings, even with Henry's guidance, as that is such a vital piece of information when communicating with a client. All three buildings that young Morgan rendered shared similarities in the materials from which they were constructed, primarily brick and limestone. ${ }^{41}$ But there were significant differences. In contrast to the Belknap School and the Louisville Boys High School, the Emmet Field School (1913-1915) was a single-story building, unique to the Crescent Hill Area in Louisville. The single story was implemented due to easy egress in case of fire. ${ }^{42}$ The elegant rendering composed by Morgan's hand had to be scaled down when built due to budgetary concerns. The school has a somewhat plain façade as compared to the others Henry built. Still in operation today and renamed Field Elementary, it went through a major renovation beginning in the late 1960s and is barely recognizable as the project Morgan drew.

The Emmet Field School in plan and scope was a bit of an anomaly for an elementary school in Louisville at the time. Perhaps Morgan was reminiscing about his tour of Europe and what he saw when visiting. The Uffculme Open Air School in Birmingham, England (1911) was a one-story plan resembling a box with movable windows for better ventilation. Morgan's repository contains file after file of magazine photos collected over the years. He clearly made a point to be in the know of what was going on in the architectural world. It was not beyond him to take an idea such as Uffculme and put his own spin on it, complete with traditional details.

The Field School project proved to be successful. In a letter dated June 3, 1920, the head of the Board of Education of Louisville, Superintendent O. L. Reid, penned to a

\footnotetext{
${ }^{41}$ See M. A. Allgeier, "Louisville Male High School," NRNF, pp. 3-4.

${ }^{42}$ Martha Elson, "Field Elementary Celebrates $100^{\text {th }}$ Anniversary," The Courier-Journal, 9 May 2015.
} 
Mr. H. H. Harris that "our Emmet Field School now consists of eight classrooms, combination auditorium and gymnasium, office, rest rooms, etc. The basement is devoted to the lunch room, play rooms, and heating plant. We consider it a most satisfactory building."43 The cost of building the school was $\$ 89,781.94$, and it opened in September 1915.

The Louisville Boys High School, one of the first educational institutions established in the city, relocated twice before it moved to its home on the corner of Brook and Breckenridge Streets in 1915, where it stayed until 1991. ${ }^{44}$ The school has a rich history, having begun its operations in 1856 as "High School" as the first high school west of the Allegheny Mountains. Known by the name of The University of Public Schools of Louisville since 1860, it granted Bachelor of Arts degrees until 1913. Renamed Louisville Male High School in the 1920s, it opened its doors to both sexes in 1952. ${ }^{45}$ With the design of this school, Henry (and Morgan), referenced past historical architecture. The impressive front entrance looks to Bramhill House, Hampshire, England (1605-1612) with only slight alterations. Charlton House, Greenwich, England (1607) was the inspiration for the rest of the building, with a different scale but the same $\operatorname{massing}{ }^{46}$

Another impressive academic edifice in Louisville shares some similar features with Louisville Boys High School. Dupont Manual High School, in Old Louisville, constructed in 1933, shares the similar imposing façade with Collegiate Gothic elements

\footnotetext{
${ }^{43}$ Letter from O. L. Reid to Mr. H. H. Harris, dated 3 June 1920. From a file on Field Elementary, located in the Jefferson County Public School Archives.

${ }^{44}$ The first home of the Louisville Boys High School was the former Louisville Medical Institute Building, which would later house Central High School.

${ }^{45}$ See "Louisville Male High School" entry in the Louisville Encyclopedia.

${ }^{46}$ M. A. Allgeier, "Louisville Male High School," National Register of Historic Places Inventory Nomination Form, p. 3.
} 
and limestone details. Although it is U-shaped in plan and contains an imposing multistoried entrance, the architect was clearly looking to past architecture for inspiration. ${ }^{47}$ This proves that Morgan was not alone in looking at past historical references to create new works.

The Belknap School, another Morgan collaboration, was fashioned using an Mshaped plan. The two-story structure sits on an elevated basement. What makes this building interesting is not the ordinary design — it is the architect's minute attention to detail. This was the last of the seven schools built by Henry with the school bond, and the last of the three that Morgan contributed to. We do not know if the master was influencing the hiree or vice versa but the latter seems likely as Morgan was a stickler for intricacy throughout his career. Researcher M. A. Allgeier, who prepared the Kentucky Historic Resources Inventory form on the school, identified the building as "containing some of the finest terra cotta ${ }^{48}$ detailing found on any building in Louisville. The tapestry-like panels contain three-dimensional foliate motifs of outstanding quality."49 The stone tympanum, enclosing the front entrance, contains an image of a lamp hovering over an open book with the words "Lux et Veritas." The windows contain mullions in varying patterns. There is a polygonal smokestack extending from the top of the building containing some of the same repetitive elements. Tapestry-like banding and brickwork are found throughout the exterior of the building.

\footnotetext{
${ }^{47}$ For more information on Dupont Manual High School, see M. A. Allgeier, "Old Louisville Residential District," National Register of Historic Places Inventory-Nomination Form, 1984.

${ }^{48}$ The material is assumed to be unglazed terra cotta but has never been confirmed.

${ }^{49}$ M. A. Allgeier, "William R. Belknap School," Kentucky Historic Resources Inventory, 1982.
} 
A letter from the school dated May 12, 1961, states that "The cost of the original building consisting of eight classrooms was $\$ 84,059.00 . "{ }^{50}$ The school received its name from a prominent Louisville businessman, William R. Belknap. Among its other notable design features, the school enjoys the distinction of having all of the brass door-knobs implanted with the bust of Mr. Belknap. Most likely these were donated by the Belknap Hardware Company, a firm with which Mr. Belknap was connected. ${ }^{51}$

A building that shares some similarities with the Belknap School is the Old Berlin High School (1918), located in Berlin, Wisconsin. According to researcher Danielle Euer, "Typical of Collegiate Gothic school buildings from the 1920s, the Berlin High School features tower-like bays that mark the building entrances, a shaped parapet line that includes projecting ornament, Tudor-arched entry surrounds, shield designs and sculptural relief detailing composed of tracery-like ornament and arches that frame recessed stone panels." ${ }^{52}$ Like Belknap School it is a two-story building on a raised basement. The scale and massing of the two institutions are very similar, although the exterior details are dissimilar. It appears that the architects were referencing the same epochs of history for their inspirations. As seen with Louisville Dupont Manual High School, the trend was for architects to reference past history when creating their designs. Perhaps this gave the buildings validity in a country that was about a century and a half years strong, as compared with the storied architectural pasts of the European counterparts.

\footnotetext{
${ }^{50}$ Letter dated 12 May 121961 from William R. Belknap School to Mr. Charles E. Sanders, Director, Division of Research, Records, and Information.

${ }^{51}$ Letter dated 12 May 1961 from William R. Belknap School to Mr. Charles E. Sanders, Director, Division of Research, Records, and Information.

${ }^{52}$ Danielle Euer, "The Old Berlin High School," National Register Nomination Form, 2016. p. 17.
} 
The Louisville Boys High School and the Belknap School both contained elements of Collegiate Gothic structures in design and massing. These buildings are typical of the school architecture being constructed in the United States at the time. This preoccupation with the Gothic style developed during the Middle Ages. Created for more than just aesthetic pleasure when its Revival was popularized beginning in the 1800 s, it inspired truth, honesty, and ethics in structures connected with religion, law, and academia. ${ }^{53}$ The style surged in popularity and became more mainstreamed through the beginning of the twentieth century. Both Henry and Morgan received Beaux-Arts training at the University of Illinois. Architects were using their traditionalist training yet tempering their styles (as with the Collegiate Gothic), still looking to the past for inspiration but inserting elements to put their own insignia on designs.

There is a pattern of continuity seen in the buildings Morgan designed during Henry's School Board contract. Emmet Field School is the exception with the one-story plan. With the others, brick and limestone are the predominant materials, with decorative accents of other materials used on the corners, around the windows, and above the doors. The accents are reflective of some other style such as Neo-Jacobean, Elizabethan, Romanesque, or even Craftsman. The buildings rely heavily on symmetry, using strong projections of horizontals and verticals for visual effects and to break up the monotony of the façades. Many of the buildings have historical inspirations, particularly from English Manor homes.

After the death of Earl Henry, the newly-formed firm of Nevin, Morgan, and Wischmeyer received their own contract from the Jefferson County Board of Education

${ }^{53}$ Emma Cogan, "Characteristics of the Collegiate Gothic Styles." https://www.loyola.edu/academics/history/architecture/glossary 
in 1922 to build an addition for the Louisville Central Colored School. The School had a long history in the city of Louisville, and had been relocated several times, mainly due to its growing enrollment, refocusing of its original mission statement, and low prioritization in the district due to the race of its student population.

When Morgan's firm accepted the contract, the school was ironically located in a building once occupied by the Louisville Boys High School. ${ }^{54}$ The building, constructed by City Engineer John Stirewalt, opened in 1845 and cost $\$ 14,000 .{ }^{55}$ In A History of Louisville Central High School 1882-1982, it describes the building as "severely simple in architectural lines. A portico topped by four huge square stone pillars reached to the third floor at the Chestnut Street entrance. An enormous hemispherical dome, which surmounted the three-story structure, was removed some years after the Civil War." ${ }^{56}$

Morgan's firm was hired to add an annex to the building complex with a budget of $\$ 125,000 .{ }^{57}$ The first level of the addition was to contain a gymnasium with showers, an auditorium with a stage, and a kitchen and cafeteria. The second level would house ten classrooms and some science labs. There was also to be some remodeling on parts of the existing building. The construction materials, brick and stucco, would match that of the existing building. ${ }^{58}$

Unfortunately, the addition was plagued with problems from the time it opened. In A History of Louisville Central High School 1882-1982, the author argues that, "the annex was so uncomfortably cold in the winter months that gas heaters were installed in

\footnotetext{
${ }^{54}$ The Louisville Boys High School (aka Male High School) was in residence in the building from 17 April 1856 to 1898. See Thelma Cayne Tilford-Weathers, A History of Louisville Central High School 1882 1982.

${ }^{55}$ Harold S Keeling, "History of Public Secondary Education in Louisville," Master of Arts Thesis U of Louisville, 1943.

${ }^{56}$ Tilford-Weathers, A History of Louisville Central High School 1882-1982, p 7.

57 "Negro High School Plans Go Out Today," The Courier-Journal, 7 July 1922, p. 14.

58 "Negro High School Plans Go Out Today," The Courier-Journal, 7 July 1922, p. 14.
} 
each room. They were inadequate, emitting more fumes than heat. Years later it was discovered that, through error, the valve to blow in heat from the Board of Education building (part of the pre-existing annex) had not been turned on." 59 The old building continued to fall apart. Central moved into new quarters in 1952 and the annex was used as storage for the Main Library in Louisville and then remained vacant for several years until it was demolished in 1974.

Central Colored School was not the type of commission where Morgan was given free reign to showcase his talents. Although Morgan was a proponent of the preservation of older structures, stucco became popular in the 1920s due to its inexpensive cost, not its durability. When the cost dipped, so did the quality. The other schools were primarily brick and limestone - Central was brick and stucco. While their Caucasian peers were attending new, impressive public collegiate-style high schools, the African American students at Central were given a "remodeled building taken over from the whites." 60 Morgan's design for the building reflects a desire to integrate into the existing annex with restrained Classical Revival elements on a two-story rectangle. Was he subliminally echoing the school system's desire for the Central students to fit into a system not created for their individual needs? None of the elaborate details of Belknap or Louisville Boys High are anywhere to be found. Porticos and pilasters are what he used for exterior ornamentation and they are so minimal that they are easily missed if not examining it closely.

Morgan was able to handle many different types of architectural projects with varying budgets and needs. Initially, Hugh Nevin was the main businessman of the firm

\footnotetext{
${ }^{59}$ Tilford-Weathers, A History of Louisville Central High School 1882-1982, p. 8.

${ }^{60}$ The Crisis magazine, October 1916, p. 299.
} 
as he had the social connections. That would soon change as Morgan became integrated into Louisville society. Not long after the completion of the Central Colored School Project, Morgan was approached to design a private educational institution. The Louisville Collegiate School, a private college preparatory school for girls, occupied a house in Downtown Louisville for a decade before a benefactor purchased land on Glenmary Avenue to allow for construction of a bigger and more impressive structure. ${ }^{61}$ Morgan was the principal in this project; his hand is evident throughout in the traditional designs and fine details. The structure remains in pristine condition, even approaching its centennial—a testimony to the architect's high standards of quality and the school's commitment to its preservation.

The initial budget for this project was $\$ 100,000$ from fundraising from private donors with a matching donation of $\$ 100,000$ from the Speed family. Fortunately for Morgan, the project turned out to be ongoing as other buildings were added by the firm over the years. Morgan was in his element, designing a school for the children of Louisville's social elite. Many of those same parents ran in his social circle and would later commission him to design their personal residences.

The school opened its doors in its present location in 1926. The Colonial Revival building, situated on an acre of land, was founded on the ideals of "the importance of a school smaller than the public schools of Louisville, where more intensive training would be possible in small classes, and college preparatory work might be one of the chief purposes." 62

\footnotetext{
${ }^{61}$ Samuel W. Thomas, Cherokee Triangle: A History of the Heart of the Highlands. Louisville: Cherokee Triangle Association, 2003. p. 138.

${ }^{62}$ The Courier-Journal. 29 November 1925, p. 8; The Courier-Journal, 22 November 1926, p. 30.
} 
The Courier-Journal stated that

the building will be of American Georgian Architecture, and will be constructed of red brick with stone trimming. Fireproof materials are to be used wherever possible. ... The interior and exterior details will be of special patterns. The unusual features of the school will include an auditorium and a dining room unit. In the auditorium wing there will be a promenade, cloakrooms, dressing rooms, a stage with a curtain, and the dining room with its kitchen and pantry. ${ }^{63}$

The exterior façade contains many typical Georgian elements such as design

symmetry, a hipped roof with dormers (a nod to Christopher Wren), a broken pediment

over the main entrance, and eight-over-eight double-hung sash windows. There are decorative stone headers over the windows. The red brick building is trimmed in traditional white around the windows and the door. The entrance has white double doors with a transom window over the top. White pilasters flank either side of the doors, nestled between vertically painted brickwork. A decorative cupola with windows reaches upwards from the center of the roof, between the matching chimney stacks at either end.

Morgan was clearly looking at historic examples of Georgian Architecture for his inspiration. His trove of images of magazine and book clippings saved over the years serve as validation. His use of the architectural elements and how he incorporated them successfully further support his understanding. Two houses that may have played a part in his designs were the Westover Plantation, Charles City, Virginia (c. 1730) and the Derby House, Salem, Massachusetts (1762). With Westover, we see similarities in the prominence of the front entrance, the symmetry of the building, and the windows. The Derby House may have influenced Morgan with the dormers, the chimneys, and the windows.

Morgan would later take on a school project which he would design in the Modern style. Nearly thirty years later than Collegiate, in 1954, Nevin and Morgan

${ }^{63}$ The Courier-Journal, 7 March 1926, p. 77. 
received the contract to put an addition on the John B. McFerran School at Cypress and Hill Streets in Louisville. The total project would cost $\$ 203,543.00$ and include 12 classrooms and a cafeteria. ${ }^{64}$ Morgan was 65 years old. The original building dated to 1914 and was built in the Classic Revival style. Typical of institutional architecture of the 1950s, the new building emphasized strong horizontal lines with a flat roof. Many of the school buildings erected during the post-war era were single story, but Morgan had to link this building to the original one with a passageway, which could be why there were two levels. The school boards at the time were less concerned with aesthetics and more focused on educating the large number of children born during the post-war baby boom, who became school age in the 1950s. The construction materials were cheaper-Morgan used concrete and steel. The roof was built-up pitch and gravel. This school was not airconditioned, unlike many of the newer buildings. Fluorescent lighting, fire alarms, and a sound system were included. Gone were the beautiful wood and marble floors of earlier days - the floors in the McFerran addition were constructed from asphalt. The windows were factory produced with aluminum frames. In Designing Schools, the author asserts that "by the mid-twentieth century, the concern was more about creating environmentally controlled, flexible, child-centered spaces and environments in which students could effectively learn." 65

Although the McFerran addition would not be something that Morgan would be remembered for, it is notable that the now senior citizen was still able to work, produce, and keep up with the latest ideas. He was referencing some of the Modern Masters, such

\footnotetext{
64 "Board Gets Bids of \$204,543 on McFerran School Addition," The Courier-Journal, 26 February 1954, p. 35.

65 Julie Willis, "Architecture in the School in the Twentieth Century," Designing Schools: Space, Place, and Pedagogy, New York: Routledge, 2017, p. 1.
} 
as Richard Neutra's Kester Avenue Elementary School (1949) Sherman Oaks, California, a strong influence on post-war school architecture. We see Morgan the businessman prevail over Morgan the architect with the McFerran School addition. Either way, he got the job completed and was able to pay his bills. 


\section{CHAPTER III \\ PUBLIC HOUSING}

"I'll plan anything a man wants, from a cathedral to a chicken coop. That's the way I make my living."

--Henry Hobson Richardson

The impetus for public housing in America may have been spawned by the Industrial Revolution in England. Cities were built near water, allowing for the transport of goods by boat. The machines in factories were powered by water and steam, before the widespread use of electricity, which also necessitated a location in the city. With the rise of the factory came a need for workers that lived in proximity, allowing them to labor for extended hours each day without lengthy commutes. The conditions of these residences (and the factories) were less than agreeable, to say the least, and most would be considered slums by today's standards. Some factory owners also were the proprietors of these dwellings, too stingy to invest their profits into the living comforts of their workers.

After public exposure of the barely-habitable conditions in England's industrial areas due to disease, infestation, and high mortality rates, reform efforts were made. There had been outbreaks of tuberculosis, cholera, smallpox, and typhoid fever. The 
water sources for the poor were contaminated and there were piles of waste and sewage infesting the overcrowded damp and dirty shanties where the lower classes were living. ${ }^{66}$ This was hardly the Garden City envisioned by Sir Ebenezer Howard (1850-1928). ${ }^{67}$ The government of England stepped in to help around the time of World War I, primarily due to the need for soldiers' lodgment after returning home from battle. The Addison Act of 1919, from which the phrase "homes fit for heroes" was coined, spurred on a rapid building program in England for the working class that was subsidized by the British government. ${ }^{68}$ These living quarters were larger and had access to a green space. ${ }^{69}$

By today's standards, the words 'public housing' quite often evokes the mental images of slums filled with run-down buildings and rampant crime. Journalist Roger Lewis believes "we should take a cue from Europe, where countries like Denmark and Austria build "social housing." Social housing is public housing, but only in the sense that it is government-financed. It is not-for-profit. European social housing is subsidized yet serves middle-class as well as low-income households, thereby avoiding many of the socioeconomic issues associated with America's public housing. ${ }^{70 "}$

Morgan would have been familiar with the housing situations in Europe from his extended travels abroad in the early teens. When he was visiting, England was on the tipping point of change; he still would have been exposed to the slum residue from the Industrial Revolution. Many of Europe's biggest reform concepts, such as social housing,

\footnotetext{
${ }^{66}$ See Edwin Chadwick, The Sanitary Condition of the Labouring Population, 1842.

${ }^{67}$ See Howard, Ebenezer, To-morrow: A Peaceful Path to Real Reform, 1898, or Garden Cities of Tomorrow, reissue, 1902.

68

ww.parliament.uk/about/livingheritage/transformingsociety/towncountry/towns/overview/councilhousing/ ${ }^{69}$ Unfortunately, the English government was only able to construct about half of the intended 500,000 units due to lack of funds. For more information see socialhousinghistory.org.uk/timeline-events/addisonact/

${ }^{70}$ Roger K. Lewis, "Let's go from 'public housing' to 'social housing,"' The Washington Post, 3 May 2013.
} 
were not enacted until after World War I. Morgan, though, was keen on International Architecture and other trends, as evidenced by his evolving designs throughout his career. He would have kept himself abreast on what was being built in Europe through magazines and journals.

The United States had many problems with its housing system. Even though it did not have the storied history of its European counterparts, the population continued to surge and citizens needed a place to call home. Poverty seemed to be concentrated in pockets of cities with larger expanding populations and manufacturing centers, and there were no established laws for building conditions. It is only when these slum areas were exposed publicly, with records kept on illness and mortality rates, that amendments were attempted and codes were enacted to try to ensure safer and more sanitary living conditions.

New York City was the first major metropolitan area in America to undergo any sort of reform with the passing of a tenement reform law in 1901. In 1910, the National Housing Association was formed, which had representation from all over the United States and parts of Canada. Individual cities began to pass their own regulations, and by 1918 Louisville, Kentucky, had a tenement housing law of its own. ${ }^{71}$

The city of Louisville, Kentucky, was facing its own set of challenges by the 1930s. Residents lost their jobs, their homes, and their savings in a matter of minutes when the Stock Market crashed in 1929. President Roosevelt's administration enacted the New Deal, beginning in 1933, which provided government-funded programs such as the Works Progress Administration, Social Security, and federally funded housing and

\footnotetext{
${ }^{71}$ For more information on the history of tenement housing reform, see Robert W. de Forest, "A Brief History of the Housing Movement in America," The Annals of the American Academy of Political and Social Science, vol. 51, Housing and Town Planning, 1914, pp. 8-16.
} 
mortgage programs. These housing projects were frowned upon due to the low-income status of the tenants; however, African Americans were turned down for mortgages. ${ }^{72}$ Author Hollenbeck wrote in 1940 that "health regulations now in effect such as the Housing Law, Building Code, and Zoning Ordinance will largely prevent the future creation of such deplorable conditions as now exist in the Negro sections. Alley dwellings may no longer be built, the density of population is subject to close supervision and sufficient open spaces must be preserved around dwelling to insure adequate ventilation. $^{73}$

The same issues occurring in Louisville, as in the rest of the United States after the Great Depression, included a growing population and a shortage of housing. After the stock market crash and the failure of the banks, businesses could not apply for the loans to build new properties as they had in the past, and most independent businesses did not have the stored capital or the incentive to build, especially when the client could not afford to pay rent. The housing areas that had fallen into disrepair were far too hopeless to be rebuilt and too hazardous for the current residents to stay. These residents had to have a place to live, so the government stepped in with the New Deal and other federal loan programs to support building mass units of low-income housing. This would also give employment to the individuals used to construct these buildings that had struggled to get by for the past several years. It seemed like a win-win solution at the time, but maybe not for all parties involved.

Segregation in the Louisville area traces its history to before the Civil War. There was a substantial population of free blacks by the $1840 \mathrm{~s}$, but they too encountered

\footnotetext{
${ }^{72}$ Roger K. Lewis, "Let's go from 'public housing' to 'social housing,"' The Washington Post, 3 May 2013.

${ }^{73}$ Howard Hollenbeck, A Housing Project in Louisville:Its Social Interpretation: A Study of College Court. Master's Thesis U of Louisville, 1940, p. 32.
} 
discrimination and limited freedoms with voting rights and education. The slave population in the city hit 10,000 before the Civil War, and by 1900, Louisville had the seventh highest population of blacks in the United States. ${ }^{74}$ Louisville remained largely segregated and as in, Making Louisville Home for Us All states, "A 'color line' created two separate worlds according to race, and in that separate and unequal world, discrimination, poverty, poor housing, crime and police brutality became commonplace. ${ }^{175}$

The white population desired to live a stone's throw away from where the blacks were residing. They wanted to be close enough where they could try to maintain some sort of control or dominance, but far enough away to not live on the same block. Making Louisville Home for Us All uses the term "layer cake" housing to describe what was going on. ${ }^{76}$ The black community bonded together and created its own support system, largely through churches and community centers. Although housing segregation was ruled as unconstitutional on November 5, 1917, the invisible lines between the black and white communities remained evident as time passed ${ }^{77}$. Von Hoffman states that

officials attempting to integrate existing public housing or locate new projects in outlying neighborhoods encountered stiff, sometimes violent, resistance. In response, housing authorities chose to situate most family projects in the slums. Public housing became associated with the inner city, impoverished dependency, African Americans, and crime. The design of projects as separate environments - a legacy of the idealism of the 1930s - and their monumental institution-like quality... underscored the role of public housing developments as stigmatized warehouses for the poor. ${ }^{78}$

\footnotetext{
${ }^{74}$ University of Louisville Anne Braden Institute for Social Justice Research. Making Louisville Home for Us All: A 20-year Action Plan for Fair Housing. 2013.

${ }^{75}$ Ibid., p.14.

${ }^{76}$ Ibid., p.13.

${ }^{77}$ Ibid.

${ }^{78}$ See von Hoffman, p. 436.
} 
As compared to the city's Caucasian residents, Louisville's black populations were not the utmost priority when designing areas for them to live. From location selection to quality of materials, their needs were usually at the bottom of the list in the first half of the twentieth century, partially because the decision makers were white. There are ongoing debates as to whether the more affluent white population gradually moved east from the city to escape the crime and decreasing property values they blamed on Blacks. One reason could be the development of the superhighways and suburbia, which escalated after World War II. Furthermore, another issue is the often overlooked Flood of 1937 and its impact on the city. Families were displaced for many weeks. Many abandoned their homes and relocated to higher areas, too fearful to remain in close proximity to the Ohio River.

Louisville's Mayor in 1939, Joseph D. Scholtz was quoted saying permanence coupled with low construction cost is the key note of this housing development in the East End and West End projects. While civic and aesthetic features have been given due weight, these projects have been considered in cold, hard dollars-and-cents figures by the commission and the architects. ${ }^{79}$

He even penned his own article in the Sunday newspaper, titled "Scholtz Sees Beecher Terrace as Great Step for Negro Race." In the article, he pontificates about how elated he was that the public housing project was erected under his administration, and that it "will be a great contribution towards the uplift of the Negro race in Louisville." ${ }^{18}$

Nevin, Morgan, and Kolbrook, in partnership with the Affiliated Architects of Brinton B. Davis, E. T. Wagner, Colley \& Hartstern, and Joseph \& Joseph were contracted to design the public housing project nicknamed the 'East End Housing Project'

\footnotetext{
79 "Housing for Poorest-Paid, Mayor's Idea," The Courier-Journal, 14 May 1939, p. 40.

${ }^{80}$ Joseph D. Scholtz, "Scholtz Sees Beecher Terrace As Great Step for Negro Race," The Courier-Journal, 9 June 1940.
} 
in the late 1930s for low-income white families. ${ }^{81}$ The site was to be located in the Phoenix Hill section of Eastern Downtown Louisville, chosen because the land was peppered with dilapidated houses. A nearby locale, also in Phoenix Hill, was selected as locale for a high-rise for indigent and disabled elderly residents as a companion project, to be named "Dosker Manor," completed in the 1960s. A sister "West End Clearance Project," Beecher Terrace, was also being erected by Nevin, Morgan, and Kolbrook with the Allied Architects (Colley \& Harstern, D. X. Murphy \& Bro., Inc., Arthur G. Tafel, Ossian P. Ward, and Wischmeyer, Arrasmith, \& Elswick) on slum-cleared tracts further west of the city to house black tenants. ${ }^{82}$

The first two public housing projects in Louisville, Kentucky, opened in 1937. College Court was a place for African Americans to live, while the LaSalle Place was erected to house only whites. ${ }^{83}$ "In 1940 two more complexes, Clarksdale and Beecher Terrace, were built as urban slum clearance projects. The four complexes were placed under the jurisdiction of the newly created Louisville Municipal Housing Commission, which later became the Housing Authority of Louisville." ${ }^{84}$ One reason for erecting large-scale housing units, as opposed to single-family dwellings, was for the governmentsubsidized loans. ${ }^{85}$ The process of building these segregated dwellings, most often in duality, remained ongoing after World War II. ${ }^{86}$

\footnotetext{
81 "Work is Under Way on 31 of the 59 Buildings in East End Housing Project," The Courier-Journal, 14 May 1939, p. 40.

${ }^{82}$ It is interesting to note that Wischmeyer and Elswick were both previous partners with Nevin and Morgan.

${ }^{83}$ Margaret Merrick, "Public Housing," The Encyclopedia of Louisville. Uof Kentucky P, 2001, p. 734.

${ }^{84}$ Ibid., p. 734.

${ }^{85}$ See Hollenbeck, p. 35.

${ }^{86}$ University of Louisville Anne Braden Institute for Social Justice Research., Making Louisville Home for Us All: A 20-year Action Plan for Fair Housing, 2013.
} 
Frederic Morgan would have been familiar with the housing movement in Europe after his travels and his study of architectural journals. To say that Morgan was an expert in public housing would be a stretch — he was more comfortable designing single-family residences for Louisville's social elite. His architectural knowledge and skill set were advanced enough that he could adapt his talents to projects that were not considered his forte. Financially he was too savvy to turn down a commission. The Allied Architects partnership, of which Morgan's firm was a part of, was paid a fee of $\$ 139,046.00$ for their services. It is interesting to note that only Morgan's firm was involved in allied partnerships in both the West End and East End housing projects.

The East End project, named Clarksdale, would cover twelve city blocks, and have 58 apartment units, each 2 or 3 stories in height, for a cost of $\$ 5,000,000$. It was the largest housing unit built in the state of Kentucky. There would also be an administration building, along with 3-, 4-, and 5-room units to house 786 families. Central parking would be provided, along with multiple play areas, storage, and a community laundry facility. Each unit would come with amenities such as steam heat, indoor plumbing facilities, a stove and a refrigerator. ${ }^{87}$ The façade, from the artist's sketch, had a very regimented and European feel to it—plain, stark, sans ornamentation, very symmetrical, and reminiscent of the Bauhaus architecture movement.

Beecher Terrace Housing Project (West End project), constructed six months after Clarksdale began, contained 808 units with 59 total buildings, covering 31.4 acres. Similar to its sister project in look and feel, the total cost of the project was

\footnotetext{
${ }^{87}$ See "Work is Under Way on 31 of the 59 Buildings in East End Housing Project," The Courier-Journal, 14 May 1939, p. 40.
} 
$\$ 4,448,169.00$, as compared to $\$ 4,598,515.00$ at Clarksdale. ${ }^{88}$ Although the Clarksdale units were slightly larger in size, the real difference between the two complexes was the skin color of its residents.

Morgan's hand is evident in the drawing of the Beecher project, the only existing elevation of either housing project. The beautiful rendering, complete with shadows on a building nestled between shrubs and trees, makes even the unadorned, cold, International Style influenced building look appealing. The building's usage is not evident from the picture — it could be anything — a school, a factory, or even a government building. Perhaps that was one of the appeals of Modernism. There were eight different variations of the same unit, altered because of their floor plan size and the location of mechanicals. The buildings were comprised of concrete foundations, brick exteriors with concrete steps, and a stone stringcourse on the façade. A similarly styled housing project which could have influenced Morgan was Techwood Homes, in Atlanta, Georgia, which, completed in 1936, was the first public housing project built in the United States. Another similar, although even simpler in design, low-rent housing project was Tasker Homes, Philadelphia, Pennsylvania completed in 1940. All the buildings share the simple brick construction with block-like massing, strong horizontals and flat roofs.

Scholar Alexander von Hoffman believes that "In the 1930s, idealistic reformers attempted to create a vast public housing program using modern architectural design. Instead they created a distinctive look that would later stigmatize its occupants." ${ }^{89}$ The architects were attempting to create a new design for America--simple, sleek, and

\footnotetext{
${ }^{88}$ Housing Authority of Louisville, Public Housing in Louisville, Kentucky, rev. 1 Dec. 1972, pp. 8-9.

${ }^{89}$ Alexander Von Hoffman, "High Ambitions: The Past and Future of American Low-Income Housing Policy," Housing Policy Debate, vol. 7, issue 3, p. 423.
} 
European inspired. ${ }^{90}$ Many idealist architects carried inflated egos and believed they could change the world with their designs. Author Teresa Almeida contends that

Le Corbusier (1887-1965) was so sure of architecture's role in social transformation that he proclaimed "Architecture or Revolution." The irony of this optimistic belief in design is that his legacy has been blamed for one of history's most ill-conceived and socially detrimental housing plans and projects - the lowincome housing projects in post-War America. ${ }^{91}$

Morgan would never work on another housing project during his career. His

style, though, was evolving with the times. His designs stayed current with the architectural trends in the United States, unless the client specified otherwise, and he continued to work in the Modern style using in vogue materials such as steel and concrete. Most of his Modern designs were only average in creativity and design. It must be noted that Morgan was designing for a conservative Midwestern town. If he had taken a leap of faith and tried to fashion a Pruitt-Igoe, for example, it would have been catastrophic from the start. ${ }^{92}$ The scale of Beecher and Clarksdale was human enough to be approachable and livable in a small river town such as Louisville, Kentucky, even if the facades were unfriendly.

Unfortunately, the good intentions of the housing projects in Louisville and other cities in the United States were outweighed by the negative aftermath. Von Hoffman contends that

social problems also plagued the public housing program. In the 1930s, the clientele ... was working-class families who had adjusted to city life and were seldom recent immigrants. In the late 1940s, conservatives in Congress and the federal housing authority pushed through a federal policy of evicting families

\footnotetext{
${ }^{90}$ Professor emeritus and Pulitzer Prize nominated author Will Morgan asserted that once the Clarksdale Housing project was completed, the rooflines had to be changed as they bore similarities to housing programs in Nazi Germany.

${ }^{91}$ Teresa Almeida, "Le Corbusier: How a Utopian Vision Became Pathological in Practice," Orange Ticker, 5 March 2013, pp. 1-2.

92 The population of St. Louis, Missouri, the location of Pruitt-Igoe, in 1950 was 816,048. The population of Louisville, Kentucky, in 1950 was 576,900. See www.demographia.com.
} 
whose income exceeded poverty-level ceilings ... which excluded many stable and upwardly mobile tenants. ${ }^{93}$

Why were Clarksdale and Beecher Terrace housing projects failures? Was it because they were neglected after they were built? Were their tenants' needs ignored by the government because of their poverty? Architectural critic Peter Blake argues that the idealisms of Modernism, as seen in the housing projects of Le Corbusier and Mies van der Rohe, failed because they served as symbols and not livable spaces. ${ }^{94}$ Critic Jacques Tati disputed that the Modern Houses are over planned and, again, unlivable. ${ }^{95}$ Although good arguments, a more logical answer for Louisville, Kentucky, could be that the residents were poor, and the projects were created to clear slums. The residents now had indoor plumbing, appliances, heat, and roofs over their heads. All their basic needs were being met, as far as the government was concerned, so once again they were put at the bottom of the social welfare system. Many of the residents of Clarksdale were families of veterans, and eventually moved to single family homes via the GI Bill. There were long waiting lists for families to get a unit at Beecher Terrace, partially because many banks would not lend money to black applicants. Over time, residents of both complexes were primarily African American. It would take more than changing locations to break the cycle of poverty for most of the inhabitants. Once the projects began to fall into disrepair, crime and drugs infiltrated and it was too late. ${ }^{96}$ The housing project had taken its residents prisoners and their chances of breaking out were very slim.

\footnotetext{
${ }^{93}$ See von Hoffman, pp. 435-36.

${ }^{94}$ See people.com/archive/whats-wrong-with-modern-architecture-plenty-says-critic-peter-blake-vol-8-no$11 /$.

${ }^{95}$ www.thecinessential.com/mon-oncle/critique-of-modern-architecture/.

${ }^{96}$ University of Louisville Anne Braden Institute for Social Justice Research, Making Louisville Home for Us All: A 20-year Action Plan for Fair Housing, 2013, p. 13.
} 
Fortunately, over sixty plus years later, the mindset of low-income housing is changing for the better. Architect Branden Klayko, who wrote a blog on architecture called Broken Sidewalk, looked toward a brighter future, stating

housing projects are what we're replacing. The Old Clarksdale Homes were torn down to create the mixed-use, mixed-income Liberty Green development. While the building does have sub-market rate apartments, it is part of a new approach to public housing called scattered site development where small numbers of units occur all throughout the city. This is a new housing development in a beautiful new building that is one of the most contextually sensitive in Louisville. Apparently 801 East Broadway (part of Liberty Green) blends in so well with its historic surroundings, Wave 3 (news channel) thought it was a renovation. ${ }^{97}$

Regrettably, a different fate has fared for Beecher Terrace. Still in operation, the slum clearance solution intended to resolve a health hazard has evolved into one. Rundown, with broken windows, some which are boarded, the area is riddled with rampant crime, drugs, and squalor. The residents, most of whom are black, have become prisoners of a cycle of poverty, and have nowhere else to go. It seems that their location, on the West cusp of Downtown Louisville, has been forgotten or is being ignored. The solution intended to "uplift" the Negro race, per Mayor Scholtz in 1940, garners only negative news coverage nearly 80 years later.

${ }^{97}$ Branden Klayko, "What Is a Housing Project?," Broken Sidewalk, 19 January 2017, pp. 1-2. 


\section{CHAPTER IV}

\section{NEW DEMANDS IN EDUCATION: LIBRARY FOR THE UNIVERSITY}

\section{OF LOUISVILLE}

"A University is just a group of buildings gathered around a library." --Shelby Foote

In early America, a library was considered a sacred space, second only to a place of worship. In fact, the first libraries were called "parish libraries" because they were affiliated with churches. ${ }^{98}$ These centers of knowledge were treasures for those who could read but could not afford to purchase books. A library, though, is so much more than just a building to store and display books and periodicals. It is a community space. It is a place for the educated and the underserved. It has no barriers - all are welcome no matter what race, nationality, gender, or religion. It is a safe place, a place for those who are seeking. Even with the computer age, the internet, and the surge in print media, its popularity has not waned. As of 2017, there are more public libraries in the United States than there are Starbucks coffee shops. ${ }^{99}$

As more and more Americans began to have access to education, these centers of knowledge began to emerge in American collegiate architecture. Pre-Revolutionary War,

\footnotetext{
${ }^{98}$ www.sturgislibrary.org/history/oldest-library/

${ }^{99}$ Sadie Trombetta, "7 Reasons Libraries are Essential, Now More than Ever," Bustle, 20 March 2017. www.bustle.com
} 
and afterwards, the paltry stacks of books at the university were usually found shelved in a corner in the chapel building. Students' access to the library was restricted or forbidden. ${ }^{100}$ Divinity schools often considered secular reading trivial. ${ }^{101}$ After a series of educational reform movements around the turn of the Eighteenth Century, Thomas Jefferson, in collaboration with Benjamin Latrobe, set a new precedent for integrating library design into campus architecture with his plan for the University of Virginia (18221826). ${ }^{102}$ His Pantheon-inspired rotunda, under the influence of Andrea Palladio (15081580), was created to house the university's collection of books, and included spaces for lectures, meetings, and study, and religious worship. ${ }^{103}$ Nearly 200 years later, it stands forefront as the centerpiece on the storied Virginia campus. Over time other universities slowly began to follow Jefferson's lead, not only with more grandiose designs but also with the hiring of professionals to draw the plans, which confirms that more importance was being placed on these structures. Other early libraries include the Robert Mills designed Greek Revival South Caroliniana Library at South Carolina College (1840). ${ }^{104}$ Harvard College hired Richard Bond for their Gore Hall (1838-41). Not to be upstaged by Harvard, Yale College contracted Henry Austin for the Yale Library (1846). ${ }^{105}$ The libraries of the latter two are English Gothic revival in plan and ornamentation, inspired by King's College Chapel at Cambridge University, England (1446-1515). ${ }^{106}$ Jefferson's timeless and pleasing designs, though, would serve as inspiration for other collegiate

\footnotetext{
${ }^{100}$ See Dale Allen Gyure for history of early libraries and their development.

${ }^{101}$ Ibid.

102 alumni.virginia.edu/learn/2012/08/27/how-jeffersons-misinterpretation-led-to-his-masterpiece-the-lawnof-the-university-of-virginia/

${ }^{103}$ Jefferson's style of architecture, though, would serve as inspiration for other collegiate libraries towards the end of the nineteenth century up until the Second World War.

${ }^{104}$ South Carolina College is now the University of South Carolina.

105 Yale College became Yale University in 1864.

106 "Gore Hall, 1838-1913-A lost Harvard Landmark, The Road to Parnassus, 10 Jan 2015.

www.roadtoparnassus.blogspot.com
} 
libraries towards the end of the nineteenth century up until the Second World War, when the International Style became prevalent. This style was ushered in by the publications of Nikolaus Pevsner's books and Siegfried Gideon's lectures, the reaction to the European housing and the industrialization movements, and the usage of new materials that were cheaper, mass produced, and more efficient. ${ }^{107}$

With the advent of educational reforms after the American Civil War, the library began to take on a more important role in education. Author Dale Allen Gyure asserts that there was a development of large, prominent libraries, centrally located and intended to symbolize the "heart of the university." ${ }^{108}$ Not only a place for the educated, the library became a beacon for educational ideals and the buildings were reflections of the hopes and dreams of an American society and culture that was starting to come into its own identity. These new buildings were designed by architects who, by looking at the past, were able to give rise to styles that glanced towards a future of a country that was approaching its first centennial. They were laying the foundation of an American style, not only with library design, but all facets of architecture. Gyure writes that "between the 1880s and the onset of World War II, a growing number of architects and planners were inspired by Jefferson's University of Virginia, Beaux-Arts pedagogy, and the City Beautiful movement to create a new generation of library buildings that provided striking visual symbols for the modern university." ${ }^{109}$

\footnotetext{
${ }^{107}$ See publishing.cdlib.org/ucpressebooks/view?docId=ft7c60084k\&chunk.id=d0e511\&toc.depth=1\&toc.id=d0e5 $11 \&$ brand $=$ ucpress

${ }^{108}$ Dale Allen Gyure, "The Heart of the University: A History of the Library as an Architectural Symbol of American Higher Education," Winterthur Portfolio, vol. 42, no.2/3 (2008), p. 107.

${ }^{109}$ Ibid., p. 117.
} 
In 1928, the Allied Architects Association of Kentucky, of which Frederic Morgan was a member, designed the Classically influenced Administration Building on the campus of the University of Louisville. ${ }^{110}$ Sarah McNabb wrote that "this group of prominent local architects, whose identity and membership were apparently fluid during the short period they served the university prior to the crash of 1929 , conceived a grandiose Baroque-planned campus outfitted with mainly American Georgian-inspired buildings." 111 The campus architecture that was being designed up until World War II was considered a tribute to learning and higher education. It was thought that an academy of high education should have examples of well-designed architecture for the sake of knowledge and prestige. It was meant to inspire the student, to elevate him or her to new levels of learning and provide a space that was not only functional but aesthetically pleasing. The Administration Building displays elements of Andrea Palladio in its Classical columns adorning its portico, and its round dome reminiscent of Jefferson's Monticello in Virginia, with roots in the Roman Pantheon. ${ }^{12}$ Architects McKim, Mead, and White, with their libraries designed for New York University (1893) and Columbia University (1897) also may have served as inspiration for the Louisville Allied Architects, as they shared similar elements in plan, massing, and design.

It was determined, though, that the Allied plan would no longer meet the needs of the University of Louisville. There were many extenuating factors, including the stock market crash, the widening and changing of traffic routes around campus, re-purposing of buildings, and a university that was growing in leaps and bounds in its enrollment,

\footnotetext{
${ }^{110}$ Other members of the alliance included W. E. Glossop, Arthur G. Tafel, Herman Wischmeyer, Fred Erhart, James J. Gaffney, Ossian P. Ward, Joseph Baldoz, J. C. Murphy, Carl Epping, and Oscar W. Holmes.

${ }^{111}$ Sarah McNabb, "A History of Campus Planning at the University of Louisville," Master's Thesis. ${ }^{112}$ Ibid.
} 
academic departments, and athletics. The university hired Jens Larson in the latter part of the 1930 s to create a new plan for the Belknap campus. ${ }^{113}$ His plan had roots in the classical tradition of architecture, which was his forte.

Jens Frederick Larson was an architect who specialized in collegiate campus design, with an unwavering loyalty to the Georgian and Georgian Revival styles, even when they were considered out of style. He served as the architect-in-residence for Dartmouth College from 1919-1947, and is most well remembered for his designs for Baker Library (1928) and Tuck Hall (1930). ${ }^{114}$ He also planned buildings for Colby College, the Institute for Advanced Study, the City University of Paris, and Wake Forest University. ${ }^{115}$ The University of Louisville erected two buildings under Lawson's plan: the J. B. Speed Engineering School (1940) and the Law School Building (1939).

When World War II broke out, many projects were put on hold. After the war, partially through the support of the G.I. Bill, enrollment once again soared at the university (and nationwide) and the subject of campus expansion arose. The economy was booming post-war, factories were humming, and Americans had cash to spend. The university wanted its campus to reflect a modern, cutting-edge research and educational facility burgeoning with the latest technology. Walter Creese (1919-2002), an ivy-league educated architectural historian who taught both art and architectural history at the University of Louisville from 1946-1958, headed up a committee appointed by the president of the university to review the Larson plan in 1949. Creese was in favor of a

\footnotetext{
${ }^{113}$ There was also an unidentified campus plan that was circulating circa 1933-1935. None of the buildings from that plan were ever constructed. See Sarah McNabb's thesis for more information.

${ }_{114}^{114}$ www.dartmouth.edu.

115 See Rod Miller, "Jens Frederic Larson and American Collegiate Gothic Architecture," Doctoral Dissertation U of Louisville, 1998.
} 
plan that looked towards the future, was modern in style, and dismissed the traditional buildings on campus as outmoded. ${ }^{116}$ He most probably was echoing the sentiments of one of the pioneers of the Modern Movement, Walter Gropius, who proclaimed, "How can we expect our students to become bold and fearless in thought and action if we encase them in sentimental shrines feigning a culture which has long since disappeared?"117

According to Sarah McNabb, "Committee members saw three reasons to investigate the modern style of architecture: 1. Flexibility of design 2. Experimental individualism of the architects and buildin3. Keeping our buildings in tempo with current political, social, and economic changes."118 Education was now for the masses, and many felt that the buildings had to be practical and user-friendly. A 1947 report issued by President Truman on higher education "proposed that every American should be educated to the best of his or her abilities. The commission additionally viewed higher education as "an instrument of social transition" rather than a mental and moral training program."119

Architectural historian Rod Miller argued that "the University of Louisville, choosing not to follow the Larson plan, instead constructed what has become standard fare for most state universities and colleges: incoherent planning in a pastiche of styles." ${ }^{120}$ To dispute Dr. Miller, inconsistent changes can be expected with shifts in leadership, trends, advances in materials, cost factors, etc., especially with state-funded

\footnotetext{
116 Sarah McNabb, Master's Thesis. p. 30.

117 explorebostonhistory.org/items/show/4 . Gropius was chair of architecture at Harvard in 1950.

118 Ibid, p. 31.

119 Dale Allen Gyure, "The Heart of the University: A History of the Library as an Architectural Symbol of American Higher Education," Winterthur Portfolio, vol. 42, no.2/3, 2008, p. 125.

${ }^{120}$ Rod Miller, , "Jens Frederic Larson and American Collegiate Gothic Architecture," Doctoral Dissertation U of Louisville, 1998, p. 57.
} 
colleges and universities. In his 1954 Report on Belknap Campus, Walter Creese contended that the availability of space, site selection and the environment (built and unbuilt), the automobile, trees and landscaping, and amenities were all important to consider when planning for a building as critical to a university as a library. ${ }^{121}$

The committee was able to work out the details of the location, and, in 1952, a $\$ 2,000,000$ bond was voted upon and issued for a new library for the University of Louisville. (The final cost of the job was $\$ 1,800,000$ ). ${ }^{122}$ The architectural firm of O'Connor and Kilham of New York was selected for the job, with Nevin and Morgan as the local associate architects. ${ }^{123}$

The partnership of O'Connor and Kilham, Jr., completed many notable commissions throughout their career. These included the Firestone Library at Princeton University, a two-story addition to the Metropolitan Museum of Art, the Avery Memorial Art Museum, as well as other collegiate structures and commercial ventures. ${ }^{124}$

The construction on the University Library began in 1955, was completed the next year and dedicated July $17,1957 .{ }^{125}$ The architects constructed a three-dimensional model to complement their plans for the building and outlined their phases of the design process, highlighting their problem-solving abilities. ${ }^{126}$ The library building serves as a bridge between the older segments of campus, and the stark, Brutalist Bingham Humanities Building to the North and Postmodern buildings such as Belknap Academic

\footnotetext{
${ }^{121}$ Walter Creese, Report on Belknap Campus, University of Louisville. February, 1954.

${ }^{122}$ Ibid.

${ }^{123}$ Incidentally, Nevin and Morgan were to begin a project of adding the Satterwhite Wing to the Speed Museum on the university's campus in 1953.

124 "Robert B. O'Connor, Architect, Dies at 97," The New York Times, 17 November 1993.

${ }^{125}$ Gail Gilbert, "University of Louisville Library," National Register of Historic Places Nomination Form, 2012.

${ }^{126}$ Creighton Gilbert, O'Connor and Kilham, Architects at Work, Exhibition Catalog, Allen R. Hite Institute, University of Louisville, 1954.
} 
Classroom Building and the Shumaker Research Building to its East and Northeast, respectively. Unfortunately, these bungling ogres are dwarfing Schneider Hall, which is falling into neglect with crumbling flagstone steps and mosaic tiles bleeding from its exterior soffits. Schneider Hall looks tired, as it approaches its Seventy-Fifth Anniversary. The porcelain panels on two sides of the building are faded, the iron railing rusted, and the paint is flaking and chipping. ${ }^{127}$

This Mid-Century Modern library oozes Americana with its modular system of construction tracing its roots back to the factory and the skyscraper. ${ }^{128}$ Although the foundation of the 71,000 square foot, rectangular two-story structure is fashioned from concrete, the walls are constructed from brick, glass, aluminum, and Alabama limestone. Gail Gilbert described the building thusly:

the main façade faces west, its windowless wall has two expanses, one of Alabama limestone and the other of red brick, broken up and linked by a glassenclosed lobby leading to a flagstone terrace. ${ }^{129}$ Two sets of broad steps lead to a lower terrace and then to sidewalks. The north and east walls have windows above wide panels that were originally blue porcelain enamel. At the west end of the north façade is a patio, the entrance to which is from a large room used for public lectures. The south wall is mostly glass with two courses of small porcelain panels. ${ }^{130}$

One of Morgan's strengths was the ability to look at what other well-known architects were designing at the time and utilize some of their ideas. Schneider Hall displays the influence of other Mid-Century buildings designed by some of the pioneers of the Modern movement. The Vyborg Library, built by Alvar Aalto in Vyborg, Russia

\footnotetext{
${ }^{127}$ The time has come for some sprucing up.

${ }^{128}$ Walter Creese, "A Library Like a Supermarket," The Courier-Journal Magazine, February 1957, p. 14. ${ }^{129}$ Gail Gilbert was head librarian at the U of L Art Library for many years. She wrote the National Register Nomination Form for Schneider Hall in 2012. When the Ekstrom Library was opened, Schneider Hall became the Allen Hite Art Institute, and the library became the art library. It still serves that same purpose in 2018.

${ }^{130}$ Gail Gilbert, "University of Louisville Library," National Register of Historic Places Nomination Form, 2012, pp. 3-4.
} 
(1927-1935), shares similarities with Schneider by using wood interior finishes and organic materials in conjunction with stucco, concrete, steel, and other man-made finishes. The strong horizontal shape of Vyborg, further accented by a top row of windows clustered in series of four, is softened by sunken reading rooms and round skylights on the interiors. The concrete horizontal box at the front entrance welcomes with a wall of glass doors and windows. ${ }^{131}$ Morgan clearly was aware of this structure as there are too many similarities for it just to be coincidental. The fluidity of Vyborg produced a more successful composition, as compared to Schneider, whose assemblage of rooms and choppy methods of egress resulted in a maze-like structure,

Another structure Morgan would have been familiar with is Triaero, the Bruce Goff designed house in Louisville, Kentucky (1940-42). The cantilevered triangular roof covers the living space, accented by two limestone retaining walls. Goff used different types of wood and glass, in combination with steel, to achieve his floating effect. This house is a more creative example of Mid-Century modern, yet the use of the natural materials and the white cantilevered entrance of Schneider and the effort to create a visual palette of creativity at every angle is similar..$^{132}$

Around the same time Morgan was working on the library, he was also working on other sizable commissions using elements of the Modern Style. When Morgan was left to his own devices to design large projects in the Modern Style, his weaknesses are apparent. Two of these works included the Lee Terminal at the Standiford Field Airport (1947-50) and the Methodist Evangelical Hospital (1957), both in Louisville. Neither building was very exciting, nor were considered 'high style.' Morgan clearly understands

\footnotetext{
${ }^{131}$ Michael Trencher, Alvar Aalto Guide. New York: Princeton Architectural Press, 1996, p. 28.

132 www.sah-archipedia.org/buildings/KY-01-111-0054.
} 
the technical use of cutting-edge materials, but aesthetically misses the mark. The Lee Terminal was a stacked three-story brick building with rows of rectangular two-pane windows surrounded by plain casings. A stone cantilevered awning hung above the triple glass door opening on the first floor. Attached to the front, the words "Lee Terminal Standiford Field" affirm the building's name and purpose. ${ }^{133}$

Methodist Evangelical Hospital was constructed in downtown Louisville- the second Methodist Hospital Morgan designed in Louisville in less than a ten-year period (the first one was never built). This multi-storied horizontal structure intersects with another facet of the same building project. A strong multi-storied vertical with three rectangular windows across highlights that junction. From that center projects a cantilevered concrete portico for automobiles to drop off patients while shielding them from the elements. Although functional and stripped of ornamentation, two tenets of Modernism, the building comes across as uninspiring and boring.

Walter Creese, with his mission to place the university at the forefront of technology and materials hired Aladar Olgyay (1910-1963) as an environmental consultant to analyze the plans and make professional recommendations. He suggested installing 73 degree tubular skylights on the library's west wall, and fixed teakwood and aluminum louvers to give solar and heat protection on the south wall. ${ }^{134}$ The louvers proved to be grossly inefficient, with the windows too hot for comfort in summer and too frigid in the winter. It is interesting to note that Creese focuses so much on the external elements of the library that he fails to mention anything about the educational goals of the new space, how the students would react to it, and if it was an environment conducive to

\footnotetext{
133 The Lee Terminal was razed to make way for a bigger airport.

${ }^{134}$ Ibid., p. 4.
} 
learning and research. Author Gyure writes that "after World War II, new government and academic policies influenced dramatically rising enrollments and broadened curricula, which, combined with a cultural shift to modernist architecture, produced a new type of library building that emphasized function over monumentality." ${ }^{135}$ Function, though, does not ensure comfort, productivity, or even longevity. ${ }^{136}$

On a different note, we see the hand of Morgan evident in the interiors of the library, which strove to use as many materials native to the Kentucky region as possible. ${ }^{137}$ American stage designer and Yale professor Donald Oenslager (1922-1982) served as advisor for the interiors. ${ }^{138}$ Morgan participated in amateur theater, and was a stickler for details, so the two most probably worked very well together on the project. Morgan was used to taking control of all facets of his projects, and it was not uncommon for him to specify interior finishes, hardware, architectural details, and even custom furniture designs. Careful planning incorporated details such as woodwork from Kentucky trees throughout the principal areas of the library. A charter for the city of Louisville, signed by Thomas Jefferson, was showcased in the lobby. Philip Rimmler (1930-2016) of New York created an inlaid curved marquetry panel from Kentucky trees, showcased in the main lobby, replicating a 1779 map of the city of Louisville. The spatial solution of the library provided for 600 patrons and 400,000 books. Spaces were allotted for reading rooms, student browsing (a new concept at the time), listening rooms,

\footnotetext{
${ }^{135}$ Dale Allen Gyure, "The Heart of the University: A History of the Library as an Architectural Symbol of American Higher Education," Winterthur Portfolio, vol. 42, no.2/3, 2008, pp.107-32.

${ }^{136}$ Did Creese promote the Modernist approach to the new library design for publicity for himself or the university? He left to teach at the University of Illinois in 1958 , just one year after the library opened its doors.

${ }^{137}$ We see this similarity with the Bruce Goff Designed house in Louisville.

${ }^{138}$ Donald Oenslager papers and designs, New York Public Library Archives and Manuscripts. www.nypl.org/the/21772.
} 
reception spaces, an auditorium and reference areas. The Robert Worth Bingham room, in the bowels of the building, housed books gifted from the benefactor's private collection. John Urbain (1920-2009), art director at Phillip Morris Tobacco Company in Louisville from 1953-1970, designed a stained glass head of Minerva inset in the North wall of glass. ${ }^{139}$

Walter Creese boasted that the building was truly American because it "used a supermarket method of collecting books from open shelves." ${ }^{140}$ Here he is equating libraries with factories, advocating for the machine, which adds an impersonal element to the project. Morgan was wise enough — by this time he was in his early sixties - to use his talents and training to complete the designs without confining himself to one style of architecture. Perhaps that was his secret to such a long a robust career. Although his talents were designing traditional spaces, he had the artistic ability to be able to take any style of architecture and make it his own.

The University of Louisville, in a proposal published by the University in 1952, declared that "more is involved [in a library] than the mere physical housing of books. To be friendly to man and to nature a library cannot be stiff, it cannot be formal, forbidding, or stylized. It must be easy to get into, more fun to be in, more replete with the amenities of modern living habits. Full use must be made of color, of comfortable furniture and pleasing materials in such a measure as to produce a satisfactory building to study in, to work in and to live in."141 This is very disturbing on many levels. Clearly the university was trying to sell the idea of a new library to the public. People do not, and

\footnotetext{
${ }^{139}$ Minerva is the Roman goddess of wisdom and knowledge, which the university used as one of its emblems, beginning in 1849. See Margaret Bridwell, "The University of Louisville Library," University of Louisville Library Handbook, 1971. For more information on John Urbain see www.johnurbain.webs.com. ${ }^{140}$ Walter Creese, "A Library like a Supermarket," The Courier-Journal Magazine, February 1957, p. 14. 141 "Proposal for Modern Library for the University of Louisville," 1 October 1952, p. 4.
} 
should not, live in the library. It is a place to learn, not a place to have fun. If the space is too comfortable the students will fall asleep studying. The library was created to give access to information and learning materials. Walter Creese echoed the sentiments of the proposal when he stated "if there is a moral to be gained from the new library it will be found somewhere in the idea that modern architecture carries the potential to improve itself into something pre-eminently human and humane if given half the chance." ${ }^{142}$ This statement by Creese completely contradicts itself. The tenets of the Modern movement eliminate all ornamentation of the past and strip a building down to its bones so that it emits truth and honesty. The purpose of the building is evident. The cold, Modern style takes away the human element and concerns itself with the purpose. Creese is trying to personify something that is man-made into something human, which is impossible.

Schneider Hall, unfortunately, has not fared well over time. After the university's enrollment continued to surge, the space was outgrown as soon as the late 1970 s. The brutalist Ekstrom library opened its doors on August 28, 1981, and now houses the marquetry map and the charter for the university. ${ }^{143}$ The former university library was renamed Schneider Hall and now houses the Margaret M. Bridwell Art Library, classrooms, art studios, and a student gallery. Only a few remnants from the former space remain after a major remodeling in $1987 .{ }^{144}$ Once hailed as cutting edge, many consider the building outdated and quirky, and have no appreciation for its historical impact on the university's campus. Frederic Morgan's legacy, however, continues to live

\footnotetext{
${ }^{142}$ Walter Creese, "A Library Like a Supermarket," The Courier-Journal Magazine, February 1957, p. 18. ${ }^{143}$ www.louisville.edu/library/ekstrom.

${ }^{144}$ www.rowlanddesign.com/expertise/exhibit/schneider-hall.
} 
on in the building with his repository of personal papers in the special collections room in the Art Library. 


\section{CHAPTER V}

\section{THE PENDENNIS CLUB OF LOUISVILLE}

"Beauty is produced by the pleasing appearance and good taste of the whole."

--Marcus Vitruvius

"Male social clubs" often evoke images of groups of men in smoking jackets in hazy paneled rooms, clustered together in comfortable chairs fraternizing and playing cards. The male-only social club has its naissance in England. Legend has it that it began in the London coffee houses in the 1700 s, and eventually permeated the rest of the island. ${ }^{145}$ The idea soon escalated and male-only social clubs were created for a plethora of reasons - some were exclusive, some social, and others political. Victorian society tried to justify membership, stating that it kept men happier when they had a place to get their wits together. In "London Club's in the Nineteenth Century," the author argues that .. c clubs are not altogether so bad a thing for family-men. They act as conductors to the storms sometimes hovering in the air. The man, forced to remain at home, and vent his crossness on his wife and children, is a much worse animal to bear than the man who grumbles his way to Pall Mall (the location of a club), and, not daring to swear at the club servants, or knock about the club furniture, becomes socialized into decency. ${ }^{146}$

To house these various clubs required buildings that could accommodate their growing memberships, which peaked in the Nineteenth Century. The more grandiose and

\footnotetext{
145 "London Clubs in the Nineteenth Century." www.avictorian.com/london_clubs.html. ${ }^{146}$ Ibid..
} 
wealthier clubs, based in London, had expansive buildings built, or remodeled, to meet their diverse needs. There were rooms for fine dining, playing games, smoking, and socializing. Wealthier clubs commissioned well-known architects to design their buildings. The Reform Club of London, established in 1836, selected architect Sir Charles Barry to design their structure after a competition. The Italianate exterior, inspired by the Farnese Palace (1541) in Rome, is nonreflective of the political mission of the club's members. The simplicity of the Portland stone minimizes the Classical aedicula detailing over the bay windows crossing the front on each of the three levels. Barry displays his confidence in his style with his attention to details, giving the club a timeless appeal. The interior, lavishly ornate with gilding, marble (both real and faux) of many colors, and oversized mirrors, exudes wealth and privilege. The grand staircase ascends to meet the full height atrium, crowned by a crystal mosaic ceiling. The prismed lights highlight an emblem in the floor. The richly stained woodwork, ornate chandeliers, and stately portraits throughout nod to the history of wealth and privilege of a time gone by. ${ }^{147}$

Across the Pacific, in America, the Union Club began in New York City in 1836. Former mayor of New York Philip Hone and his well-connected friends " invited two hundred and fifty 'gentlemen of social distinction' to join the new club ... which would be similar in its plan and regulations to the great clubs of London, which give a tone and character to the society of the London metropolis." ${ }^{148}$ The membership eventually expanded to 400, which became the standard cap for membership across the United

\footnotetext{
${ }^{147}$ www.reformclub.com

148 James Nevius, "The Rise and Fall of New York City’s Private Social Clubs," 17 June 2015. www.nycurbed.com
} 
States. ${ }^{149}$ The club movement in America did not escalate until after the Civil War, during the Gilded Age (1870s-1890) and the Progressive Era (1890-1920). Private social men's clubs were created for all types of shared interests-university clubs for the educated, political clubs, artist and intellectual clubs, immigrant clubs, etc. If a group felt excluded from a club, they would often start their own, such as the Harmonie Club, started by German Jewish immigrants denied membership into the Union Club. ${ }^{150}$

In Chicago, for example, black Americans formed their own social clubs, which grew out of burial societies formed after the close of the Civil War to help ease costs for funeral plots. These clubs were also primarily exclusive by gender, but also had their own regulations as far as skin color, social position and educational level. The club members participated in the same activities as the white clubs-socializing and playing cards. $^{151}$

There were other activities taking place in the clubs that were not as wholesome as chatting about business, mutual interests, or fine dining. Author Amanda Fiegl argues that "supper clubs were what a Chicago Tribune article from October 20, 1899 defined as "where the pampered sons of fortune meet Bohemians upon a common level and engage in revelry—where fools are duped and criminals are bred." Places that advertised themselves as where "both ladies and gentlemen of the theatrical and kindred professions could find rest and recreation after their evening's exertions." 152 She elaborates that "in 1900, mentions of supper clubs were often included in the New York Times' page

\footnotetext{
${ }^{149}$ Ibid.

${ }^{150} \mathrm{Ibid}$. It is interesting to note that on the Harmonie Club's website, none of this information is mentioned. It states that the club was formed due to mutual interests of the members in singing and other activities, hence the name. See www.harmonieclub.org.

${ }^{151}$ Janita Poe, "Role of Social Clubs Changes with Times," 9 February 1994. www.chicagotribune.com.

${ }^{152}$ Amanda Fiegl, "Supper Clubs Without Depravity," 9 November 2010. www.smithsonianmag.com.
} 
headlined: 'Some Happenings in Good Society.' But during the days of Prohibition, 'supper clubs' seem to have become another name for a speakeasy."153

No matter what was occurring behind the scenes, the popularity of private social clubs grew to include organizations in forty- seven states. In Louisville, Kentucky, the Pendennis Club was established in downtown Louisville in 1881 as an exclusive, all white-male club for socializing and business. ${ }^{154}$ Several influential Louisville businessmen were involved in its inception, and initially dubbed it the "Calumet Club." The name "Pendennis" was suggested after a William Thackeray novel, The History of Pendennis. ${ }^{155}$ Needing a space to call its own, the club moved twice before purchasing the former home of W. R. Belknap (1811-1889), the founder of Belknap Hardware and Manufacturing Company. ${ }^{156}$ The home was purchased for $\$ 30,000$ in $1883 .{ }^{157}$ Located at 332 West Walnut Street in Louisville, Abraham Dagworthy Hunt, the home's original owner, commissioned an unknown architect to build the house. Historian Sam Thomas, in The Architectural History of Louisville, described the home as a

five-bay, brick residence with quoins at the corners and also outlining a slightly projecting central pavilion topped by a flat pedimented gable. The stuccoed front façade was not scored, accentuating the elaborate window frame detail. The windows were mammoth compared to the door, which had a huge transom of glass squares, all set behind Corinthian columns in antis. He (Hunt) lived in the house but a week before selling it to John Bell and taking a trip to Europe. ${ }^{158}$

\footnotetext{
${ }^{153}$ Ibid.

${ }^{154}$ Black and Jewish men were barred from joining the club. That policy was changed towards the end of the twentieth century and now welcomes all races, creeds, and genders. See Jo Ferguson, "Pendennis Club," Encyclopedia of Louisville, Lexington: UP of Kentucky, 2001.

${ }^{155}$ Joanne Weeter, unpublished paper submitted as classwork for Goucher College.

${ }^{156}$ William R. Belknap (1849-1914), whom the Belknap School was named after, is the son of William B. Belknap, and became president of Belknap Hardware after his father died.

${ }^{157}$ Pendennis Club Pamphlet. 1928.

${ }^{158}$ Samuel W. Thomas, The Architectural Histoory of Louisville 1778-1900. Louisville: George Rogers Clark Press, 2009, p. 122.
} 
The club, once again needing more room due to increasing membership, contracted architects McDonald and Dodd of Louisville to add a three-bay addition to the existing structure in 1909 , for a cost of $\$ 50,000 .{ }^{159}$ This addition would only serve the needs of the club for about a decade. By the 1920s, the subject of expansion arose again. It was decided that the club would hire the firm of Nevin, Wischmeyer, and Morgan to design and build a new, almost 80,000 square foot building for a cost of $\$ 1,000,000 .{ }^{160}$ Nevin, a member of the club, handled most of the business negotiations between the two parties. The building's new address was 218 West Walnut Street, about a block from their former location.

The National Register of Historic Places Registration Form describes the 1928

structure as

a three-story, Georgian Revival structure of brick and Indiana limestone with a rectangular plan, a low-pitched, hipped roof, and a front porch. The walls, chimneys, and roof balustrade are made of brick, the terrace, porte-cochere, pilasters, and other decorative details are constructed of Indiana limestone, and the foundation is composed of reinforced concrete. A balustrade surrounds the front terrace with a shallow, iron balcony above the simple stone arched entrance. A central arrangement of windows separated by four stone pilasters with Corinthian capitals rises from the second story behind the balcony. The windows have arches of brick with stone keystones. The wide stone entablature includes an architrave, frieze, and a cornice that is emphasized with dentils and brackets. The entablature is capped with a balustrade that surrounds the roof. The interior of the Club was inspired from original Georgian and Adam buildings. The 3rd floor ballroom was patterned after a room in Crichel House in Dorset, England. ${ }^{161}$

\footnotetext{
${ }^{159}$ Edward J. Mehren, ed., Engineering Record, Building Record and Sanitary Engineer, vol. 59, 6 March 1909, p. 39.

160 "Pendennis New Home to be One of Finest in Country," The Courier-Journal, 29 November 1927, p. 1.

${ }^{161}$ Christina Mitchell, "Pendennis Club," National Register of Historic Places Registration Form, 2003, p. 5 .
} 
With this project, we see Frederic Morgan at his finest. By utilizing references to historical architecture he skillfully interprets the Georgian and Classic Revival styles and creates one of the finest examples of the style in this region. ${ }^{162}$

Morgan not only devised the floor plan of the club, but also specified the architectural details for the interiors. ${ }^{163}$

The building's primary entrance along Muhammad Ali Boulevard was originally intended for use only by the club's gentlemen members, while the side entrance with its formal porte-cochere was intended for female guests. Aside from the grand third floor ballroom, one large main dining room and nine private dining rooms, the Pendennis features seven card rooms, a billiard room, a library, a writing room, a Rathskeller, a center lounge, and a lady's reception. In addition, the Club's athletic facility features squash courts, which were once a rarity in Louisville. Finishes on the interior of the Pendennis were lavish and included gum, maple, oak, pine, teak, and walnut woods, marble, gilding, and even handblocked Zuber wallpaper. ${ }^{164}$

Worth noting is that the Pendennis Club differs greatly from one of its contemporaries, the Columbia Club, in Indianapolis. Constructed in 1925, the latter structure strands ten stories high in the center of downtown Indianapolis. Although the architects of the building, Rubush and Hunter, used Gothic and Renaissance Revival elements in its details, the façade presents a more contemporary look with its steel and concrete frame. The immense, eye-catching oriel window is main focal point of the limestone façade. ${ }^{165}$ This building, however, presents itself as cold and commercial as compared to the welcoming, domestic feel, of the Pendennis Club.

\footnotetext{
${ }^{162}$ The members of the Club are so proud of their headquarters that very nominal changes have taken place over the years.

${ }^{163}$ Bittners Design Firm of Louisville was hired for the interior design of the project. Morgan most probably was very involved with Bittners in the selections.

${ }^{164}$ Christina Mitchell, "Pendennis Club," National Register of Historic Places Registration Form, 2003, p. 10.

${ }^{165}$ Mary Ellen Gadski, "Columbia Club," National Register of Historic Places Inventory Form, US Department of the Interior, 1983.
} 
The Knickerbocker Club, of New York City, was completed by the architectural firm of Delano and Aldrich in 1915. The architects, clearly looking at past historical styles for inspiration, relied heavily on the Federal style for their designs. One of the major strong points of the elevation is the architects' successful handling of the rectangular massing. The three-story red brick and white trim building has seven tall, vertical double sash windows across the primary two levels, smaller ones on the third level and decreased fenestration in the attic. Their integration of Federal elements such as a roof balustrade, a broken pediment over the Adams-esque main entrance, and classical modillions further add to the traditional treatment of the exterior. ${ }^{166}$

Another historic male social club designed with Georgian elements is the Hartford Club, Hartford, Connecticut. Completed in 1903, the Boston firm of Andrews, Jacques and Rantoul fashioned the Georgian Revival structure from red brick and white trim. Residential in feel, the three-story building has five bays across the front. The windows, accented with limestone details are arched in the central section of the second level. The end windows contain limestone fan medallions above with classical details. The focal point of the façade is the beautifully curved portico accented with six Corinthian columns. Above is an elegant balustrade which draws one's eye to the arched window directly above. ${ }^{167}$

Morgan would have been familiar with the two clubs mentioned above and they could have served as inspiration for his designs. The Pendennis Club, though, was not

\footnotetext{
${ }^{166}$ Ruth Selden-Sturgill, "Knickerbocker Club Building," Landmarks Preservation Commission, 11 September 1979, p. 5.

167 "Hartford Club," National Register of Historic Places Inventory Nomination Form, 1984.
} 
the only nonresidential building that his firm designed in the Classic Revival style. ${ }^{168}$ The Schuster Building (1927), The University of Louisville Administration Building (1928), and the Alumni Chapel at the Southern Baptist Theological Seminary (1950) were also projects for the firm. The 35,000 square foot Schuster Building, located in the Louisville Highlands, was designed to hold mixed-use tenants, which included the Uptown Theatre, apartments, shops, and businesses. ${ }^{169}$ The two-story building, which sits on a corner intersection, is divided into sections. The three-story Uptown Theatre building in the center is highlighted by a cupola, a Georgian traditional element.

The University of Louisville Administration Building (1928) was completed by Morgan with the Allied Architects. It was patterned after Jefferson's designs at Monticello and the University of Virginia. ${ }^{170}$

The landscape architectural firm of Frederick Law Olmsted, who completed the plans for the grounds of the Southern Baptist Theological Seminary, referred Morgan for the Alumni Chapel commission (1950). ${ }^{171}$ This was quite an honor. Morgan had used the firm for many of his projects over the years so the two had a working relationship. Frederick Law Olmsted (1822-1903), the father of landscape architecture, himself had designed the park system for Louisville in 1891, and his reputation was second to none. After his passing, his firm carried on his legacy. Morgan's design for the chapel shows his sensitivity to the setting and to other buildings already on campus, several of which displayed elements of the Georgian style. Typically, Morgan, referencing the past,

\footnotetext{
168 Interest in the style peaked after 1926, with the genesis of the restoration project at Colonial Williamsburg.

${ }^{169}$ www.triposo.com/poi/Schuster_Building.

${ }^{170}$ For more information on the University of Louisville Administration Building, see chapter on University of Louisville Schneider Hall.

${ }^{171}$ www.archives.sbts.edu/the-history-of-the-sbts/our-buildings/alumni-chapel/
} 
designed the Alumni chapel with simplicity and elegance. The church looks very similar in scale and design to the Federated Church of Sturbridge, Massachusetts. The quiet demeanor of the building does not distract from the setting or its sense of purpose.

By the 1960s in America, membership in male social clubs started to die off. This can be attributed to many factors, the first being time. Society today runs at a rapid pace. Many families have both parents that work, or there is only a single parent in the household. The goal after a long day is to go home, make dinner, and get kids to bed. Another reason is that the generation of men who were 'clubbers' were starting to die off. The new generation had other interests. Finally, racial and gender stereotypes made the clubs unattractive to many people. Even when rules were changed so that all races, creeds, and genders were welcome to join, the history and stigma that went along with the clubs turned many off. The Pendennis Club was not without its own controversy. Daniel Lawless, the editor of the digital magazine, Plume, wrote "in 1978, after Ali had won the heavyweight championship an unprecedented third time and was possibly the most recognized man in the world, Louisville renamed Walnut Street, the 'Black Broadway,' Muhammad Ali Boulevard. Shortly thereafter the Pendennis Club, an allwhite, all-male bastion of old-line money and influence that fronted on the newly renamed street, changed its address to an out-of-the-way side door on Second Street."172

The institution of the Pendennis Club has survived conflict and managed to keep open its doors for over a century. New, younger, diversified memberships now enjoy the amenities the club offers. From dining to business networking to elegant social functions, the Pendennis Club prevails as a landmark in the heart of Downtown

${ }^{172}$ Daniel Lawless, Plume, 19 July 2016. www.plumepoetry.com 
Louisville. Because of Frederic Morgan and his firm, the building will continue its classic and timeless appeal for future generations. 


\section{CHAPTER VI}

\section{CONCLUSION}

"In the spirit of this classic tradition I feel sure lies the greatest promise of art [architecture] in the future"

--Frederic Lindley Morgan

Frederic Morgan lived and practiced architecture in Louisville, Kentucky for over half a century, carefully negotiating the architectural and social changes. Morgan designed in both the traditional and modern styles of architecture. To quote Mr. Morgan, "An architect must have classic proportions instilled into him-always in the back of his head." 173

In 1949, Frederic Morgan was one of 28 architects made a Fellow of the American Institute of Architects. His citation read: "An able delineator, he has jealously fostered and ably developed the traditional residential design of his native state, animating and vitalizing it with his own peculiarly fine discrimination." ${ }^{174}$ While he championed good proportions, well-crafted materials, and a respect for history, he was not a form giver or a vocal theorist, like his Modern contemporaries, Walter Gropius or Mies van der Rohe. Frederic Lindley Morgan largely changed the face of public architecture in mid-twentieth-century Louisville. His solid accomplishments in

${ }^{173}$ The Courier-Journal, Sunday, 5 December 1954, p. 107.

174 The Courier-Journal, Sunday, 20 March 1949, p. 55. It is to be noted that Morgan was born in Illinois, so calling Kentucky his native state was an error. 
creating beautiful and useful works of architecture contributed to an enriched architectural landscape and living environment.

In 1968, ten Louisville architects were asked to vote on the best and worst older buildings (built over ten years) in Louisville. The Pendennis Club was hailed as the fourth best building in the city. Conversely, the Lee Terminal at Standiford Field Airport was voted the fourth worst building. ${ }^{175}$ Morgan was able to execute his designs in both the traditional and modern styles. Although he is best remembered for his traditional buildings, his knowledge of materials, ability to stay current with architectural trends, and confidence in his own ability allowed him to keep working in an era when traditional architecture largely fell out of fashion.

Morgan will not be remembered for his Modern designs. He was able to execute the style in a manner acceptable to the client. His heart, though, was that of a traditionalist. His classical designs have rendered a timelessness to them, especially his residential designs. He referenced the past but was able to adapt early American forms to contemporary living. His extensive catalog of works, largely unknown until recently, contribute to the history of Louisville architecture and to a better understanding of the pressures, directions, and values of America in the Twentieth Century.

\footnotetext{
${ }^{175}$ Douglas Nunn, "Architects in Poll Consider Our Older Architecture Superior," The Courier-Journal,
} Sunday, 18 February 1968. p. 80. 


\section{REFERENCES}

Allgeier, M .A. Louisville Male High School. National Register of Historic Places Inventory Nomination Form, 1979, p. 3.

---. Old Louisville Residential District. National Register of Historic Places Inventory Nomination Form, 1984.

---. William R. Belknap School. Kentucky Historic Resources Inventory, 1982.

Almeida, Teresa. "Le Corbusier: How a Utopian Vision Became Pathological in Practice." Orange Ticker, 2013, pp. 1-2.

American School Board Journal, vol. 60, p. 76.

"Architects Honor Morgan for His Residential Designs." The Courier-Journal, Sunday, 20 March 1949, p. 55. www.newspapers.com.

Architects Macomber and Morgan. Grove Gazette, Historic Locust Grove, 2007.

Baker, John Milnes. American House Styles: A Concise Guide. New York: W. W. Norton, 1994.

Baker, Lindsay. A History of School Design and Its Indoor Environmental Standards, 1900 to Today. Washington, DC: National Institute of Building Sciences, 2012, p. 3.

"Board Gets Bids of \$204,543 on McFerran School Addition." The Courier-Journal, 26 February 1954, p. 35.

Bomier, B. Renaissance of the American School Building: A Story of Blending Health, Safety and Environment with American Education. Anoka, MN: Environmental Resource Council, 2014, p. 9.

Bridwell, Margaret. University of Louisville Library Handbook. The University of Louisville Library.

Chadwick, Edwin. The Sanitary Condition of the Labouring Population, 1842.

Clay, Grady. "The Allens Finish Their Dream House-And It Really Is." The CourierJournal, Sunday, 5 December 1954, p. 107. www.newspapers.com 
Cogan, Emma. Characteristics of the Collegiate Gothic Styles. www.loyola.edu/academics/history/architecture/glossary.

Connelley, William Elsey, and E. Merton Coutler. "Frederic Lindley Morgan." History of Kentucky, Volume IV, Kentucky, American Historical Society, 1922.

Creese, Walter. "A Library Like a Supermarket." The Courier-Journal Magazine, February 1957, p. 14.

---. Report on Belknap Campus. University of Louisville, February 1954.

de Forest, Robert W. "A Brief History of the Housing Movement in America." The Annals of the American Academy of Political and Social Science, Housing and Town Planning, vol. 51, 1914, pp. 8-16.

"Designing Nine Churches." The Courier-Journal, Sunday, 11 June 1922, p. 37. www.newspapers.com.

Donald Oenslager papers and designs. New York Public Library Archives and Manuscripts. www.nypl.org/the/21772.

Donovan, John Joseph. School Architecture. New York: MacMillan, 1921.

"Education." The Crisis Magazine: A Record of the Darker Races, October 1916, p. 299.

Elson, Martha. "Field Elementary Celebrates 100th Anniversary." The Courier-Journal, 9 May 2015.

Estate papers of Maud Lindley Morgan.

Euer, Danielle. "The Old Berlin High School." National Register Nomination Form, 2016, p. 17.

Ferguson, Jo. "Pendennis Club." Encyclopedia of Louisville. Lexington: UP of Kentucky, 2001.

Fiegl, Amanda. "Supper Clubs Without Depravity." 9 November 2010. www.smithsonianmag.com.

Filler, Martin. Makers of Modern Architecture. New York: New York Review of Books, 2007, p. xvi.

"Frederick Lindley Morgan." AIA Nomination Form, 16 September 1948, pp. 2-3. www.public.aia.org.

"Frederic Lindley Morgan." World War I service application. www.ancestry.com. 
Gadski, Mary Ellen. "Columbia Club." National Register of Historic Places Inventory Form, US Department of the Interior, 1983.

Gilbert, Creighton. O'Connor and Kilham, Architects at Work. Exhibition Catalog, Allen R. Hite Institute, U of Louisville, 1954.

Gilbert, Gail. "University of Louisville Library." National Register of Historic Places Nomination Form, 2012.

"Gore Hall, 1838-1913—Lost Harvard Landmark." The Road to Parnassus, 10 Jan. 2015. www.roadtoparnassus.blogspot.com.

Gyure, Dale Allen. "The Heart of the University: A History of the Library as an Architectural Symbol of American Higher Education." Winterthur Portfolio, vol. 42, no. 2/3, 2008, p. 107.

Hammon, Stratton. The Story of a House, 1989. Unpublished Paper.

"Hartford Club." National Register of Historic Places Inventory Nomination Form, 1984.

Hindman, High D. Labor: An Child American History. New York: Routledge, 2015.

Hitchcock, Henry-Russell. Architecture: Nineteenth and Twentieth Centuries. New Haven: Yale UP, 1977.

Hollenbeck, Howard. "A Housing Project in Louisville: Its Social Interpretation: A Study of College Court." Master's Thesis U of Louisville, 1940, p. 32.

Housing Authority of Louisville. Public Housing in Louisville, Kentucky. Rev. 1 December 1972, pp. 8-9.

"Housing for Poorest-Paid, Mayor's Idea." The Courier-Journal, 14 May 1939, p. 40.

"Housing Unit Design Gets U.S. Approval." The Courier-Journal, 4 October 1941, p. 13.

Howard, Ebenezer. 1898. To-morrow: A Peaceful Path to Real Reform or Garden Cities of To-morrow, reissue, 1902.

Jeffery, Jonathan. "Brinton Beauregard Davis." The Louisville Encyclopedia. Lexington: UP of Kentucky, 2001.

Keeling, Harold S. "History of Public Secondary Education in Louisville." Master of Arts Thesis, U of Louisville, 1943. 
Kennedy, Rachel, and Cynthia Johnson. Kentucky Historic Schools Survey: An Examination of the History and Condition of Kentucky's Older Schools. Kentucky Heritage Council, 2002.

Klayko, Branden. "What Is a Housing Project?" Broken Sidewalk, 19 January 2017. www.brokensidewalk.com.

Kleber, John,ed. "Louisville Male High School." Encyclopedia of Louisville. Lexington: U of Kentucky P, 2001, p. 558.

Lawless, Daniel. Plume. 19 July 2016. www.plumepoetry.com

Letter from O. L. Reid to Mr. H. H. Harris dated 3 June 1920. From a file on Field Elementary, located in the Jefferson County Public School Archives.

Letter from Walter Creese to William Morgan (1944- ) dated 14 May 1994. Frederic Morgan Files at U of Louisville Art Library.

Letter from William R. Belknap School to Mr. Charles E. Sanders, Director, Division of Research, Records, and Information, dated 12 May 1961.

Lewis, Roger K. "Let's go from 'public housing' to 'social housing."' The Washington Post, 3 May 2013.

"London Clubs in the Nineteenth Century." www.avictorian.com/london_clubs.html

"Louisville Collegiate School." The Courier-Journal, 22 November 1926, p. 30.

McNabb, Sarah. "A History of Campus Planning at the University of Louisville." Master's Thesis U of Louisville, 1999.

Mehren, Edward J., ed. Engineering Record, Building Record and Sanitary. Engineer, no. 59. 6 March 1909, p. 39.

Merrick, Margaret. "Public Housing." The Encyclopedia of Louisville. Lexington: U of Kentucky P, 2001, p. 734.

Miller, Rod. "Jens Frederic Larson and American Collegiate Gothic Architecture." Doctoral Dissertation U of Louisville, 1998.

Mitchell, Christina. "Pendennis Club." National Register of Historic Places Registration Form, 2003, p. 5.

"Negro High School Plans Go Out Today." The Courier-Journal, 7 July 1922, p. 14. 
Nevius, James. "The Rise and Fall of New York City's Private Social Clubs." 17 June 2015. www.nycurbed.com

Nunn, Douglas. "Architects in Poll Consider Our Older Architecture Superior." The Courier-Journal, Sunday, 18 February 1968, p. 80. www.newspapers.com.

Parker, John Henry. A Concise Glossary of Architectural Terms. London: Studio Editions, 1992.

Pendennis Club Pamphlet. 1928.

"Pendennis New Home to be One of Finest in Country." The Courier-Journal, 29 November 1927, p. 1.

"Phone Exchange Contract Awarded." The Courier-Journal, 7 March 1926, p. 77.

Poe, Janita. "Role of Social Clubs Changes with Times." 9 February 1994. www.chicagotribune.com.

"Robert B. O'Connor, Architect, Dies at 97." The New York Times, 17 November 1993.

Sam Thomas Files, University of Louisville Archives.

Sam Thomas Lecture, Filson Club Historical Society, 24 September 1995, p, 3.

Scholtz, Joseph D. "Scholtz Sees Beecher Terrace as Great Step for Negro Race." The Courier-Journal, 9 June 1940.

Selden-Sturgill, Ruth. "Knickerbocker Club Building." Landmarks Preservation Commission, 1979, p. 5.

Share, Allen. Cities in the Commonwealth: Two Centuries of Urban Life in Kentucky. Lexington: UP of Kentucky, 1982, p. 76.

"\$68,000 of $\$ 100,000$ Needed to Match Sum Offered for School Here has been Raised." The Courier-Journal, 29 November 1925, p. 8.

The J. B. Speed Memorial Museum, Louisville, Kentucky. Exhibition by Architects of Louisville, Kentucky. 1-15 February 1931, Exhibition Catalogue.

Thomas, Samuel W. Cherokee Triangle: A History of the Heart of the Highlands. Louisville: Cherokee Triangle Association, 2003, p. 138.

---. The Architectural History of Louisville 1778-1900. Louisville: George Rogers Clark P, 2009, p. 122. 
---. The Village of Anchorage. Anchorage: Anchorage Civic Club, 2004.

Tilford-Weathers, Thelma Cayne. A History of Louisville Central High School 18821982. Louisville: n.p., 1982, p. 7.

Trencher, Michael. Alvar Aalto Guide. New York: Princeton Architectural P, 1996, p. 28.

Trombetta, Sadie. "7 Reasons Libraries are Essential, Now More than Ever." Bustle, 20 March 2017.

University of Illinois Architectural Journal.

University of Louisville Anne Braden Institute for Social Justice Research. Making Louisville Home for Us All: A 20-year Action Plan for Fair Housing. 2013.

Von Hoffman, Alexander. "High Ambitions: The Past and Future of American LowIncome Housing Policy." Housing Policy Debate, 1996, vol. 7, no. 3, p. 423.

Weeter, Joanne. Unpublished paper submitted as classwork for Goucher College.

Willis, Julie. "Architecture in the School in the Twentieth Century." Designing Schools: Space, Place, and Pedagogy. New York: Routledge, 2017, p. 1.

"Work is Under Way on 31 of the 59 Buildings in East End Housing Project." The Courier-Journal, 14 May 1939, p. 40.

Wrenick, Frank E. The Streamline Era Greyhound Terminal: The Architecture of W. S. Arrasmith. Jefferson, NC: Mcfarland, 2011, p. 53.

www.archives.sbts.edu/the-history-of-the-sbst/our-buildings/alumni-chapel/.

www.archives.syr.edu/collections/fac-staff/sua_wella_n.htm.

www.brokensidewalk.com/2015/jones-dabneybuilding.

www.bustle.com.www.dartmouth.edu.

www.demographia.com.

www.harmonieclub.org.

www.johnurbain.webs.com.

www.kyhistry.pastperfectonline.com 
www.louisville.edu/library/ekstrom.

www.parks.ky.gov.

www.parliament.uk/about/livingheritage/transformingsociety/towncountry/towns/ overview/councilhousing/.

www.people.com/archive/whats-wrong-with-modern-architecture-plentysays-critic-peterblack-vol-8-no-11.

www.reformclub.com.

www.rowlanddesign.com/expertise/exhibit/schneider-hall.

www.sah-archipedia.org/buildings/KY-01-111-0054.

www.socialhousinghistory.org.uk/timeline-events/addison-act/.

www.thecinessential.com/mon-oncle/critique-of-modern-architecture/.

www.triposo.com/poi/Schuster_Building. 


\section{APPENDIX I}

\section{CATALOG OF WORKS}

*All dates are approximate

*All buildings are located in the Louisville, KY area, unless noted

\section{$\underline{\text { Educational Institutions }}$}

Emmett Field School (under Henry), 1913-1915,

120 Sacred Heart Lane, Louisville 40206

Belknap School (under Henry), 1913-15, 1800 Sils Avenue, Louisville 40205

Parts of Boys High School (under Henry), 1913-1915,

911 South Brook Street, Louisville 40203

Central Colored School, 1922 Addition/Renovation

Ninth and Chestnut Streets, Louisville 40202

Louisville Collegiate School, 1926,

2427 Glenmary Avenue, Louisville 40204

Harrodsburg High School, 1930,

Harrodsburg, KY

Wiseman Group of Buildings, Centre College, 1939,

Danville, KY

Baptist Women's Missionary Unions Training School, 1940

Centre College Dormitories, 1940, 1967,

Danville, KY

Danville Frye House,

Centre College, Danville, KY

Centre College, Breckinridge Hall (renovation)

Danville, KY 
Weisiger Music and Arts Building (including theater), Centre College, 1954, Danville, KY

University of Louisville, Administration Building "Grawemeyer Hall," 1929, Louisville, KY

University of Louisville, Belknap Gates and Entrance Oval, 1930, Louisville, KY

University of Louisville, Schneider Hall, 1956, Louisville, KY

John B. McFerran School, 1954 Addition, 1900 South Seventh Street, Louisville 40208

\section{Churches}

First Presbyterian Church, 1921 addition, 318 West Kentucky Street, Louisville 40203

First Presbyterian Church, 1922, 185 North Maple Avenue, Covington, VA 24426

Highland Methodist Church, 1922, 1140 Cherokee Road, Louisville 40204

Zion Evangelical Church, 1922, 1310 East Burnett, Louisville 40217

Speed Memorial Church, 1924, 328 US-31, Speed, IN 47172

First Presbyterian Church, 1924, Lebanon, KY

Concordia Lutheran Church, 1925-1930 (Plan by Ralph Adams Cram), 1127 East Broadway, Louisville 40204

Crestwood Methodist Church, 1925?, 7214 Kavanagh Avenue, Crestwood, KY 40014

Highland Presbyterian Church, 1930 remodel/Sunday School addition, 1011 Cherokee Road, Louisville 40204

Strathmoor Presbyterian Church, 1948, 2201 Hawthorne Avenue, Louisville 40205 
St. Francis in the Fields Church, 1948, 6710 Wolf Pen Branch Road, Harrods Creek, KY 40027

New Alumni Chapel, Southern Baptist Theological Seminary, 1949, 2825 Lexington Road, Louisville 40280

Harvey Brown Presbyterian Church, 1952,

311 Browns Lane, Louisville 40207

Second Presbyterian Church, 1957, 3701 Old Brownsboro Road, Louisville 40207

Broadway Baptist Church, 1958, 4000 Brownsboro Road, Louisville 40207

Edenside Christian Church, 1927 Church Tower, 1415 Bardstown Road, Louisville 40204

Audubon Baptist Church?, 1944, 1046 Hess Lane, Louisville 40217

Lulbegrud Church, 1925?, Mt. Sterling, KY

Jeffersontown Presbyterian Church, 1963, 10409 Taylorsville Road, Louisville 40299

Christ Church United Methodist, 1957, 4614 Brownsboro Road, Louisville 40207

First Evangelical Lutheran Church, 1960 educational unit, 417 East Broadway, Louisville 40202

St. Matthews United Methodist Church, 319 Browns Lane, Louisville 40207

St. John's Evangelical Church, Renovations and Addition, 637 East Market Street, Louisville 40202

$\underline{\text { Clubs }}$

Louisville Boat Club, 1921 (Destroyed by Fire), 4200 River Road, Louisville 40207

Pendennis Club, 1928, 218 Muhammad Ali Blvd, Louisville 40202 
River Valley Club, 1930,

4701 River Road, Louisville 40222

Louisville Country Club, 1958 Renovations, ? New outdoor swimming pool, 25 Mockingbird Valley Trail, Louisville 40207

Wynn Stay Club, 1930,

228 West Muhammad Ali Blvd, Louisville 40202

Art Club, 1935

St. Matthews YMCA?, 1955,

Could not confirm it was ever built

Shawnee YMCA?, 1955,

Could not confirm it was ever built

South End Branch YMCA?, 1955, Could not confirm it was ever built

\section{Other Buildings}

A. T. Hert Memorial Bridge, 1922, Cherokee Park, Louisville, KY

Home Telephone Company Holy Angels Academy, 1923

Home Telephone Company Exchange, 1922,

Second and Lee Streets, Louisville, 40208

Schuster Building, 1927,

1500 Bardstown Road, Louisville 40205

WHAS Radio Transmitter Station, 1928,

Taylorsville Road near Jeffersontown, Louisville 40299

William Walker Co., 1929,

603 Fourth Avenue, Louisville 40202

Fort Harrod Restoration based on drawings by W.W. Stephenson, 1931, Harrodsburg, KY

Fort Harrod Mansion Museum, 1932,

Harrodsburg, KY 
Monarch Auto Co., 1938,

Corner of Brook and Broadway, Louisville 40203

Sutcliffe Store, 1938,

225 South Fourth Street, Louisville 40202

Ann Lewis?, 1940

Ardens?, 1941

Shackleton Piano Company, 1947,

Lexington, KY

Shackleton Piano Company?, 1948,

307 West Broadway, Louisville 40202

Herbert F. Boehl Law Office

Lexington, KY

G. Bittner and Sons (Rotary Oildraulic Elevator),

731 East Main Street, Louisville 40202

Porter Paint Company, 1948,

801 South Third Street, Louisville 40203

Stewart's Downtown Parking Garage, 1945,

3rd and Guthrie, Louisville 40203

Kentucky Military Institute (New Barracks), 1922,

Lyndon, KY

Bacon's Department Store, 1951,

3939? Shelbyville Road, Louisville 40207

Presbyterian Seminary Presidents House

Strickland Printing Company, 1926,

Louisville, KY

Lincoln Marriage Temple, 1931 (Relocation/Reconstruction), Pioneer Memorial State Park, Harrodsburg, KY

Old Odd Fellows and Rebecca's Home, 1922, Eminence, KY 
Kosair Crippled Children's Hospital (addition), 1939, 982 Eastern Parkway, Louisville 40217

Lee Terminal, Standiford Field Airport, 1950, 600 Terminal Drive, Louisville 40209

Methodist Evangelical Hospital, 1957, 315 East Broadway, Louisville 40202

Evangelical Hospital, 1927, designed but never built

Shelby and Preston at Eastern Parkway, Louisville 40217

Commonwealth Life Insurance Office, 1960,

Columbus, IN

Cumberland Falls Hotel,

Corbin, KY

Louisville Board of Trade, 1944?, 301 West Main Street, Louisville 40203

National Guard Armory, 1955, Beuchel, KY

Synodical Presbyterian Orphanage of the Southern Church at Anchorage, 1929, Anchorage, KY 40223

Methodist Hospital, 1949, designed but never built Emerson and Dundee, Louisville 40205

King's Daughters Hospital, 1952, Shelbyville, KY

Ephraim McDowell Memorial Hospital, 1945, Danville, KY

W. S. Speed Industries, 1963

Locust Grove Cottage Restoration, 1961-1962, 561 Blankenbaker Lane, Louisville 40207

Harrodsburg Memorial Park, Harrodsburg

Farmington (Restoration?)

3033 Bardstown Road, Louisville 40205 
Independent Life Insurance Co., 1962

Presbyterian Home for Aged Ladies (Renovation), 1948,

Conrad-Caldwell House, 1402 St. James Court, Louisville 40208

Industrial Bank, 1928

Grand Lodge of Kentucky Free and Accepted Masons?

Jones Dabney Company, 1935, 1954,

1495 South Eleventh Street, Louisville 40219

Kaufman-Straus Store (Alterations), 1926, 427 South Fourth Street, Louisville 40202

Kentucky Children's Home Society Complex, 1925, Lyndon, KY 40222

Satterwhite Wing, J. B. Speed Art Museum, 1953, 2035 South Third Street, Louisville 40208

Addition to Shawnee Telephone Exchange, 1950, Louisville

Exchange of Cumberland Telephone and Telegraph Co., 1926, Louisville

Goodwill Industries, 1952 (Addition), 214 South Eighth Street, Louisville 40202

Masonic Office SAR, 1954,

Fourth and Kentucky, Louisville 40203

Puritan Apartment Complex, 1950 (Remodel of Blue Room), 1244 South Fourth Street, Louisville 40203

Citizen Fidelity and Trust Co. (15,000 sq. ft. addition), 1952, Fifth and Jefferson Streets, Louisville 40202

United Furniture Store, 1947, Jackson and Market Streets, Louisville 40203

W. T. Grant Co. Junior Dept Store, 1958, New Albany, IN 
Boyle County Health Unit, 1951,

Boyle County, KY

\section{$\underline{\text { Residences }}$}

Alden, Mr. and Mrs. William, 1933,

440 Lightfoot Road 40207

Allen, Mr. and Mrs. Charles W., 1936?, 4020 Glenview Avenue, Glenview KY 40025

Allen, Mr. and Mrs. Winthrop (Louisa), 1954, 3731 Fairway Lane, Louisville 40207

Almstedt, Florence L., 1930s?, 444 Lightfoot Road, Louisville

Anderson, Carola,

Zorn Avenue, Louisville

Anderson, Mr. Dwight, 1937 ,

2350 Valetta Lane 40205

Baird, Paul,

Green Tree Manor (renovation?)

Ballard, G. Breaux, 1927,

5402 Snow Hill Road, Glenview, KY 40025

Bass, Mr. and Mrs. Albert L., 1929,

420 Mockingbird Hill Road 40207

Bass, Ray

Bayless House "Cross Creek," 1929 Addition

1116 Bellewood Road 40223

Blakely, Gen. C. S., 1939, 4709 Brownsboro Road, Louisville 40207

Bonnie, Mr. and Mrs. Ned

Booker, 1936

Bradshaw, Mr. W. E., 1924 (Additions and Alterations to Residence), Paducah, KY 
Broaddus, Russell, 1935,

3341 Brownsboro Road, Louisville 40207

Bennet, Mr. W. J., 1942,

South 6th Street?

Brown, Mr. W. L. Lyons and Sara, 1937 (extensive renovations after 1937 flood),

"Ashbourne," 6328 Upper River Road, Harrods Creek, KY 40027

Butler, Mr. Thomas L., 1922,

60 Hill Road, Louisville 40204

Callahan, J. M., 1936,

Blankenbaker Lane, Louisville 40207

Cary, Mr. and Mrs. Graddy, 1927,

83 Warrior Road, Louisville 40207

Clay, John Harris, 1937,

Paris, KY

Cochran, Archibald, 1925,

25 Stonebridge Road, Anchorage, KY 40223

Collings, Ben H.,

2200 Newburg Road?

Collis, Mr. and Mrs. John V., 1927

Collis, Mr. and Mrs. John V., 1936,

3740 Upper River Road 40207

Conrad, Mr. Stanley,

2438 Broadmeade Road, Louisville 40205

Cook, Mr. Garnett (Carolyn), 1938, 1966 addition (Cobble Court), 4318 Glenview Ave 40222

Cooper, Mrs. Robin, 1932

Courtenay, James, 1938,

493 Lightfoot Road, Louisville 40207

Courtenay, James Clark, 1927,

12004 Hazelwood Road, Louisville 40223 
Cumnock, Mr. and Mrs. Walter, 1922,

1420 Castlewood Road, Louisville 40204

Dabney, Mr. William C., 1937,

3760 Upper River Road, Louisville 40207

Dixon, Mr. and Mrs. William B. (Matilda), 1925,

2614 Top Hill Road, Louisville 40206

Downing, Mr. John R., 1935,

2217 Cherokee Parkway, Louisville 40204

Dumesnil, Mr. and Mrs. Edward Roland, 1928,

1711 Sulgrave Road, Louisville 40205

Dunkerson, Mr. and Mrs. Casselberry, 1922,

2304 Speed Avenue, Louisville 40205

Durham, Joseph H., 2325 Cherokee Parkway, Louisville 40204

Durham, R. A., 1935,

Eastleigh Subdivision

Felder,

2837 Riedling Drive, Louisville 40206

Fitzhugh, Henry, 1964 remodel,

Wolf Pen Branch Road, Prospect 40059

Frank, Dr. Edward,

3733 Canoe Lane, Louisville 40207

Frazier, Amelia Brown,

2500 Longest Avenue, Louisville 40204?

Fuller Residence

Gibson, Mr. W. C., 1952,

1701 Evergreen Road, Anchorage, KY 40223

Girdler, Walter,

1801 Sulgrave Road, Louisville 40205

Graff, E. Sloane, 1932,

2225 Village Drive, Louisville 40205 
Haggin, Louis Lee II, 1940,

Lexington, $\mathrm{KY}$

Haldeman, Walter, 1933,

3609 Glenview Avenue, Louisville 40222

Haldeman, Bruce, 1927, "Breezehill,"

3760 Upper River Road, Louisville 40207

Hancock, Mr. A. B., 1941,

Lexington, $\mathrm{KY}$

Hanry House, 1922,

Eastern Parkway

Haynie, Mrs. L. M., 1926,

2029 Willow Avenue, Louisville 40204

Henning, James,

Lime Kiln Lane, Louisville 40222

Hermann, Mr. Louis, 1951, ?Door Detail

Heuser, Mr. and Mrs. Henry Sr., 1951, 12 Overbrook Road, Louisville 40207

Hibbs, Jack and Marjorie, 1965 , 5810 Orion Road, Louisville 40222

Hickman, Mrs.

Hill, Mrs.,

969 Cherokee Road?

Hilliard, Mr. Byron '27 (built by Judge Bingham for Robert who never lived in it), 5001 Avish Lane, Harrods Creek, KY 40027

Hogue, Mr. and Mrs. Francis, 1936, 434 Lightfoot Road, Louisville 40207

Ivins, Mr. and Mrs. J. C., 1922, 500 Kenwood, Louisville 40214

Ivins, Mr. and Mrs. J. C., 57 Hill Road, Louisville 40204 
Ivins, Mr. and Mrs. J. C., 1929,

416 Mockingbird Hill Road, Louisville 40207

Jackson Residence, 1929

Kendall, Mrs. Hattie

Knebelcamp, Wathen, 1935,

701 Sunnyside Drive, Louisville 40206

Laird residence

Logan, Mrs. Dulaney, 1943

Lucheto, Angelo,

Lot 14 Trevillian Park

Maclean, Angus,

Mead's Landing Farm, Goshen, KY 40026

Marshall, Mrs. John Sr., 1930 (Renovation?),

Anchorage, KY 40223

McCord, Mrs. John, 1963,

433 Club Lane, Louisville 40207

McElwain, Henry, 1940,

407 Mockingbird Valley Road, Louisville 40207

Milner, B. Hudson, 1938,

2501 Top Hill Road, Louisville 40206

Morrison, Mrs. Christine, 1936

Nevin, Hugh, 1922,

952 Cherokee Road, Louisville 40204

Ogden, Mr. and Mrs. Squire, 1936,

402 Mockingbird Valley Road, Louisville 40207

Oldham, Mr. and Mrs. John (Emily), 1940 (Wing Added), 1823 Ballard Mill Lane, Louisville 40207

Owens, F. W., 1957 
Payne Residence

Peabody, J. R.,

River Hill Road, Louisville 40207

Pearson, Mr. Paul

Porter, Mr. Harry Boone, 1930 (Ridgeley),

7404 Brownsboro Road, Louisville 40241

Potter, Mr. Douglas

Pryor, Mr. and Mrs. W. R., 1929,

539 Garden Drive, Louisville 40206

Reed, Mr. and Mrs. William, 1931,

Mockingbird Valley Road, Louisville 40207

Reutlinger, Mr. and Mrs. Adolf, 1928 (Cardinal Hill?),

2550 Trevilian Way, Louisville 40205

Rodes, Mr. Jack,

1322 Cherokee Road, Louisville 40204

Rodes, Mr. and Mrs. Joe,

2220 Village Drive, Louisville 40205

Rodes, Mr. and Mrs. Joe (Barbara), 1970,

400 Mockingbird Valley Road, Louisville 40207

Ross, Mrs. Charles, 1928 (enlargement of Bayless/Barrett house),

1116 Bellewood Road, Anchorage, KY 40223

Sanford, Eugene, 1964,

Blankenbaker Hill, Louisville 40207

Scheirich, Mr. and Mrs. Henry J., 1957,

10 Overbrook Road, Louisville 40207

Smith, R. Lloyd, 1955,

Crawfordsville, IN

Spalding, Mr. and Mrs. J. Greig, 1940, Warrior Road, Louisville 40207 
Starks, Mr. Frank W., (1929 or 1937?),

37 Hill Road, Louisville 40207

Starks, Franklin Sr.,

23 River Hill Road, Louisville 40207

Stewart, Mrs. J. Edgar,

2525 Ransdall Avenue, Louisville 40204

Stodghill, Mrs.

Sutcliffe Residence, 1930s

Taylor-Oldham-Herr House, 1940 (Colonial Revival Wing Addition), 1823 Ballard Mill Road, Louisville 40207

Thompson, Mr. and Mrs. Frank (Anna Hogue), 1968, 3301 South Rose Island Road, Prospect, KY 40059

Thompson, Mr. and Mrs. Frank B. (Ida Webb), 1929, 502 Lightfoot Road, Louisville 40207

Thompson, Mr. and Mrs. James Pitkin, 1929, 499 Lightfoot Road, Louisville 40207

Times, Courier-Journal Demonstration Home, 1933, 315 Jarvis Lane, Louisville 40207

Todd, Jouett Ross Sr., 1938, 408 Mockingbird Terrace, Louisville 40207

Todd, Jouett Ross Jr., 1964 (Rostrevor), Alta Vista Road, Louisville 40206

Townsend, Dr. H. L.

Troutman, Dr. and Mrs. Woodford B.

Tway, Mr. Robert Chester, 1923 (Plainview Farms), 10235 Timberwood Circle, Louisville 40223

Unidentified House?,

Paris, KY

Van Winkle, Mr. and Mrs. Julian, 1954,

5 Woodhill Road, Louisville 40207 
Wallace, P. M.

Watson, Mr. Alexander Mackenzie, 1929 (Drumenard),

6401 Wolf Pen Branch Road, Prospect, KY 40059

Whayne, Roy C.

Wolfman, Joe, Addition?

Willett, Mr. and Mrs. Roscoe, 1923,

58 Hill Road, Louisville 40204

Henry Gray/Wood, Judge Lorenzo, 1929 (Sherley Mansion, External and internal renovations),

2106 Homewood Drive, Anchorage, KY 40223 


\section{APPENDIX II}

\section{FIGURES}

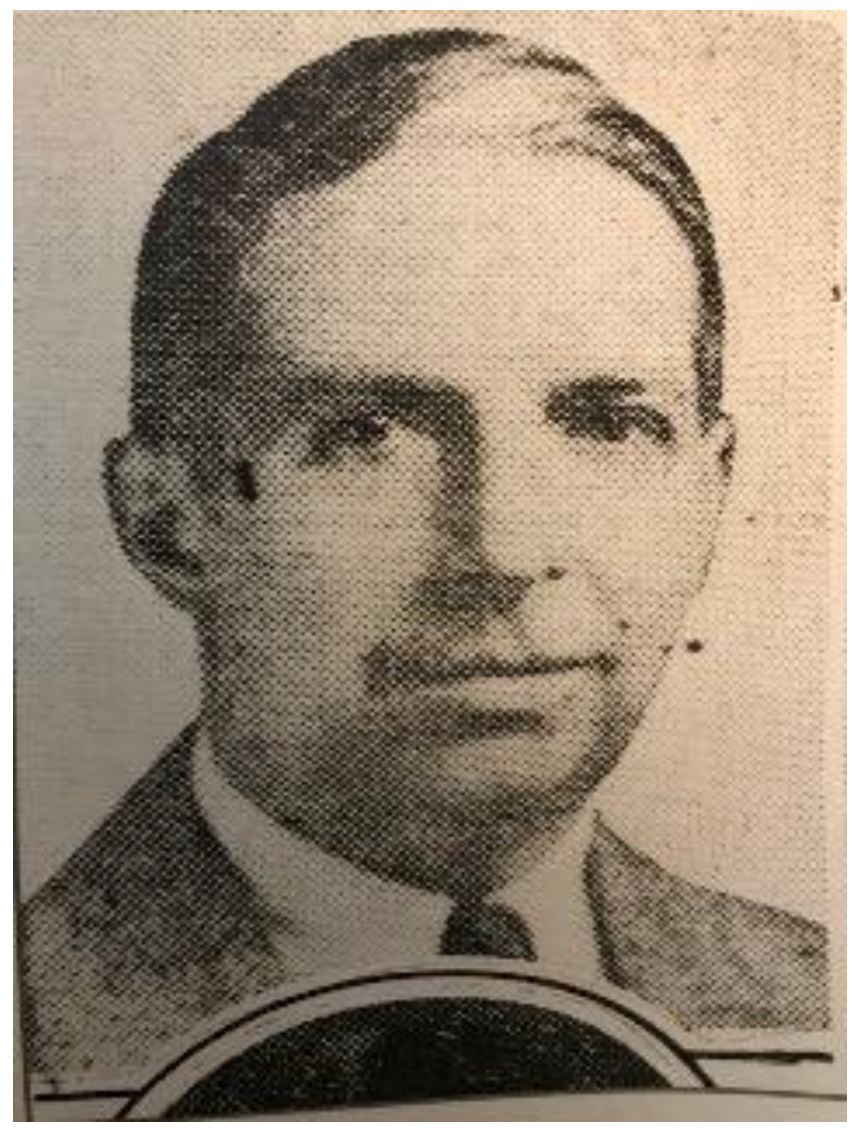

Figure 1. Portrait of Frederic Lindley Morgan. No photo credits given. Published in The Courier-Journal. February 23, 1930. www.newspapers.com. 


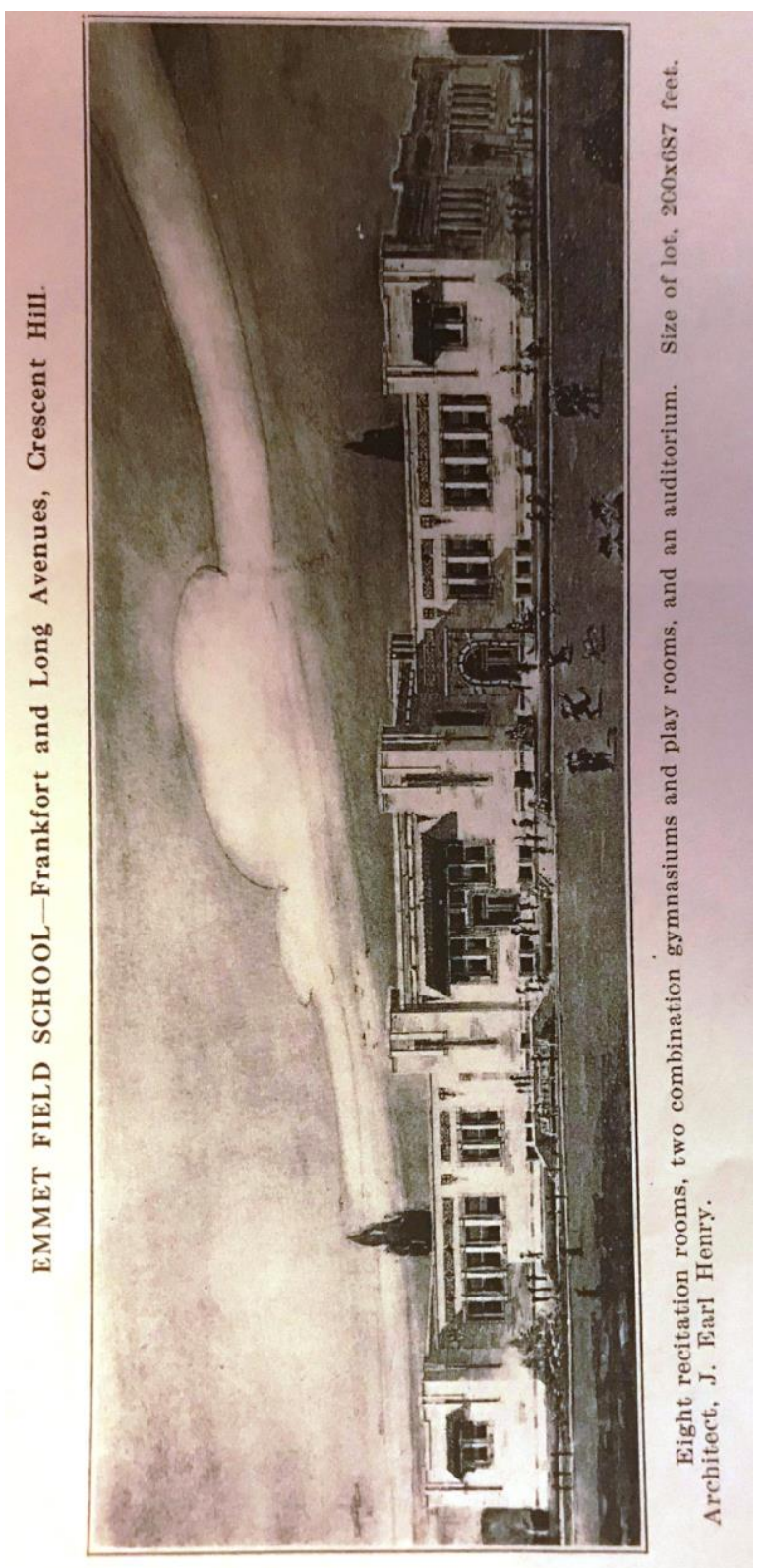

Figure 2. Emmet Field School Rendering. No photo credit given. Jefferson County Public School Archives and Records. 


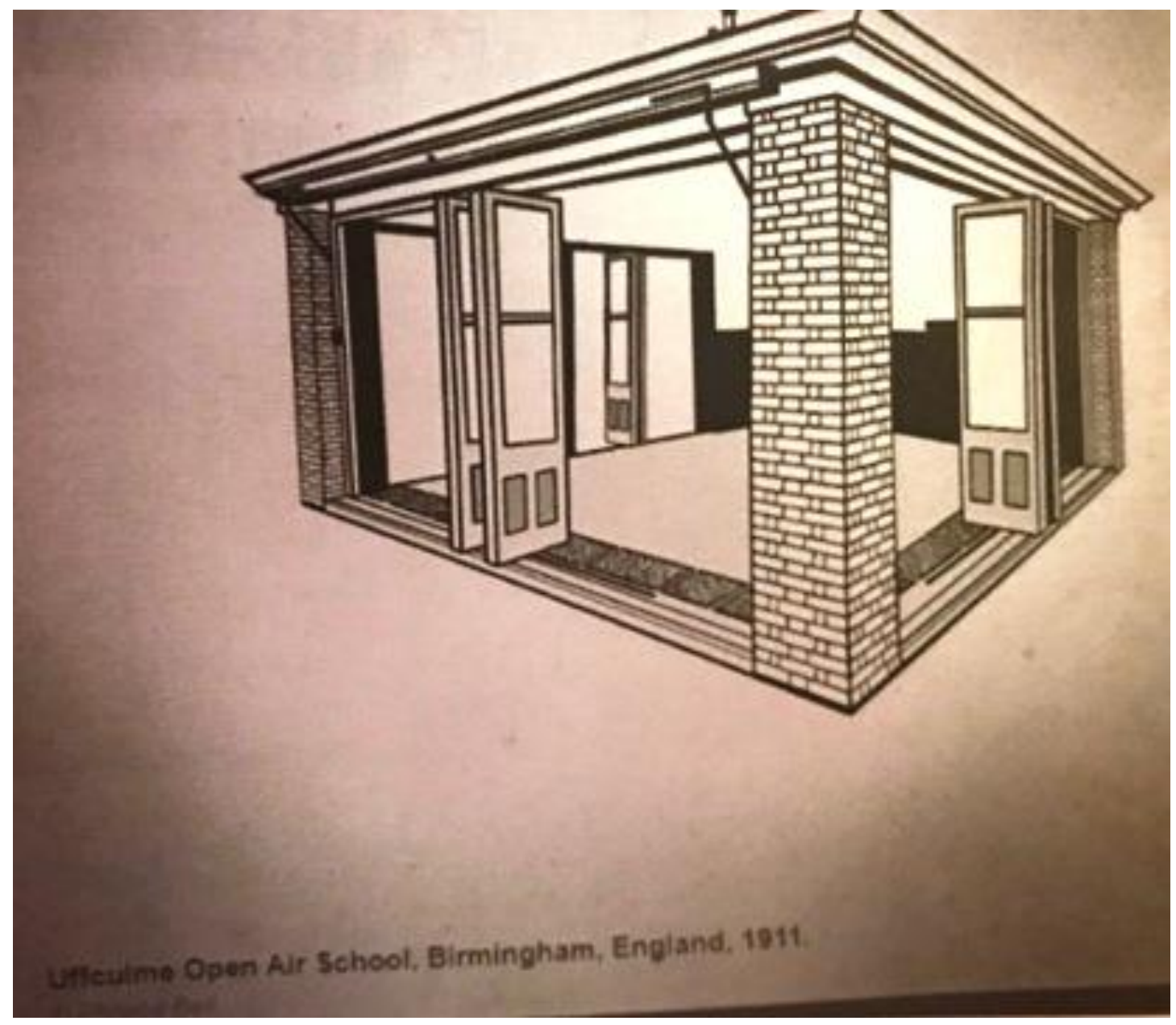

Figure 3. Uffculme Open Air School, Birmingham, England. Phoebe Bell. Published in School Design through the Decades. www.mosaicscience.com. 


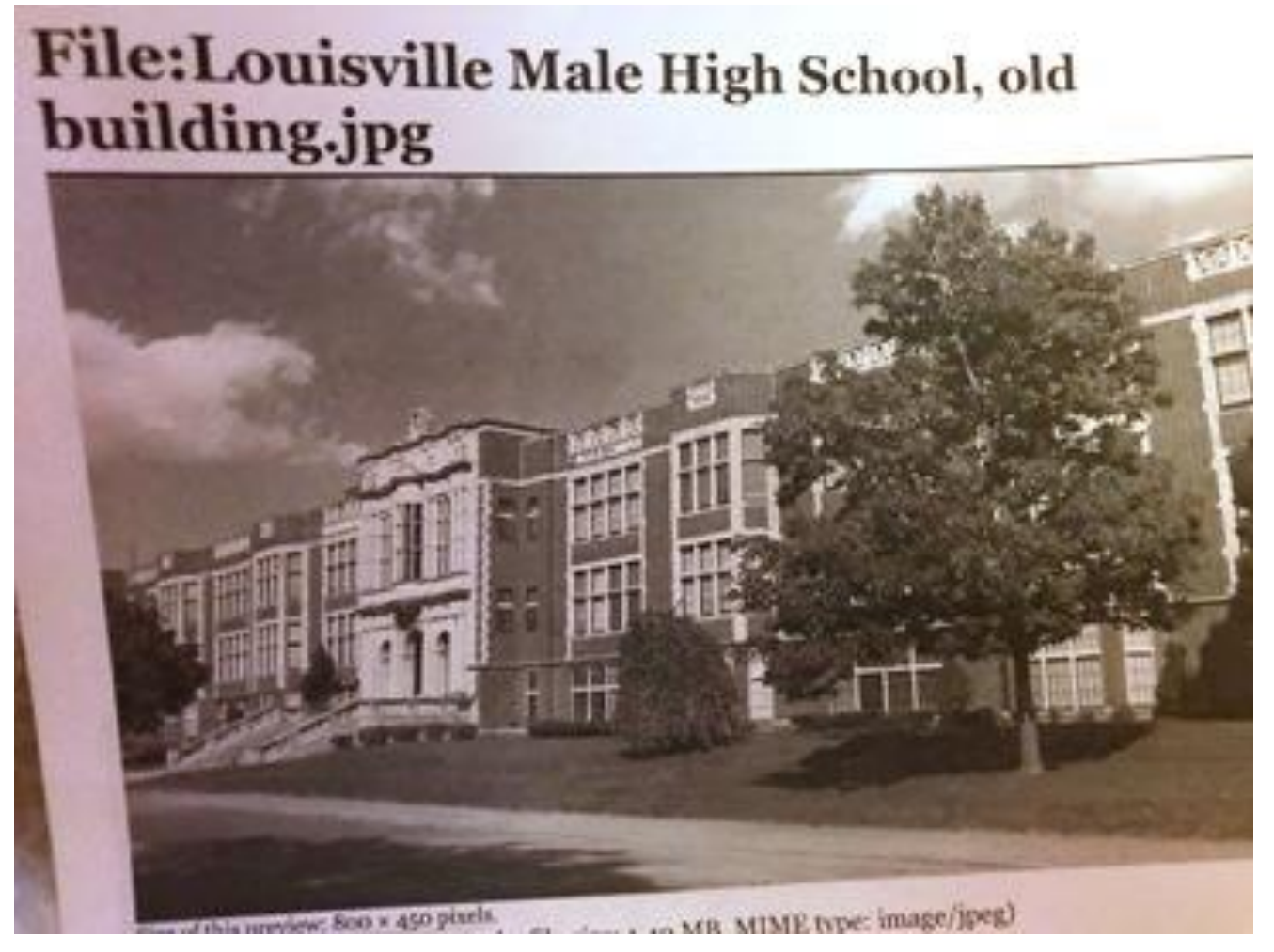

Figure 4. Louisville Male High School. www.nps.gov/assetdetail/NRIS/79001011. 


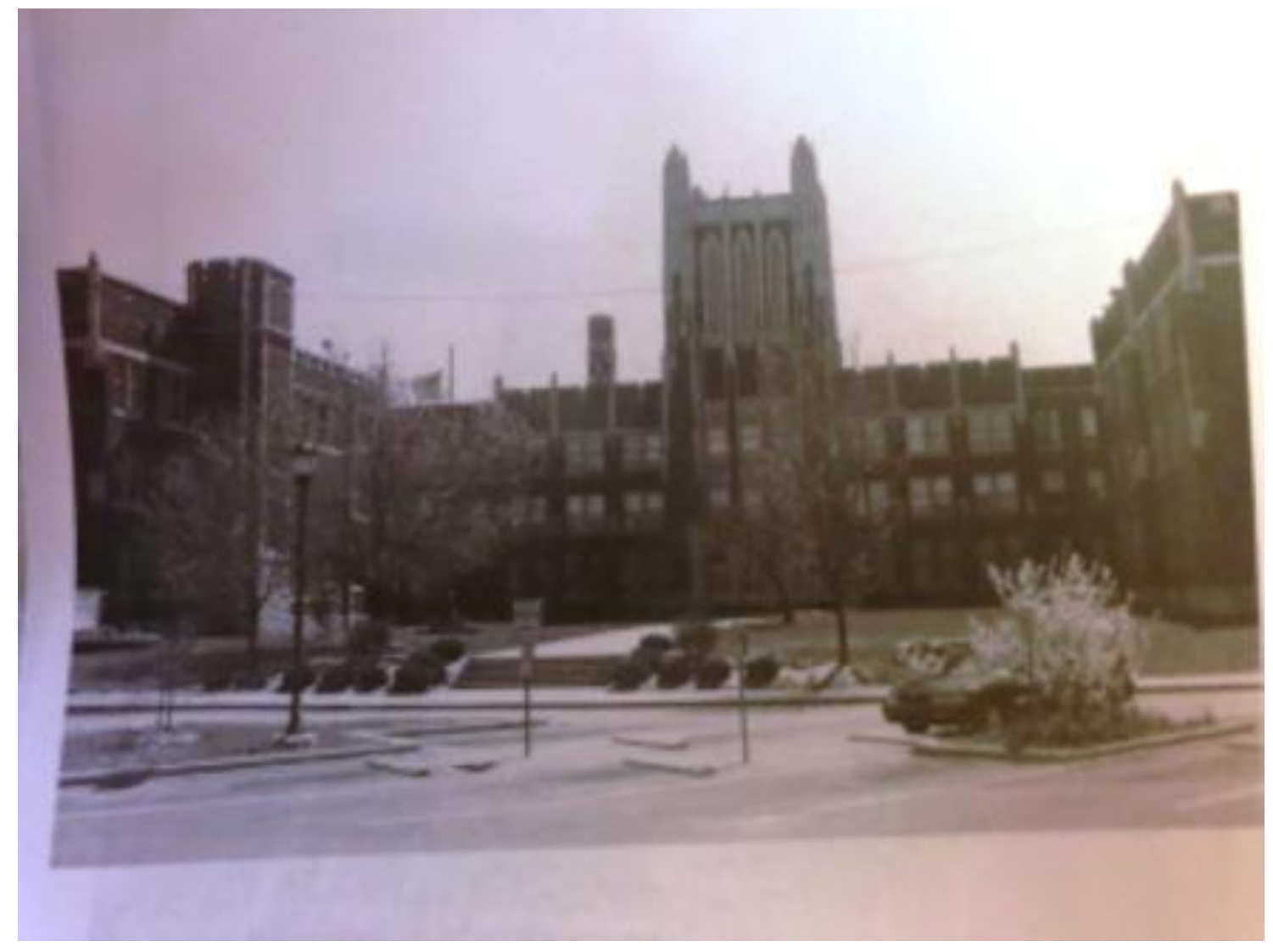

Figure 5. DuPont Manual High School. W. Marsh. en.wikipedia.org/wiki/DuPont_Manual_High_School. 


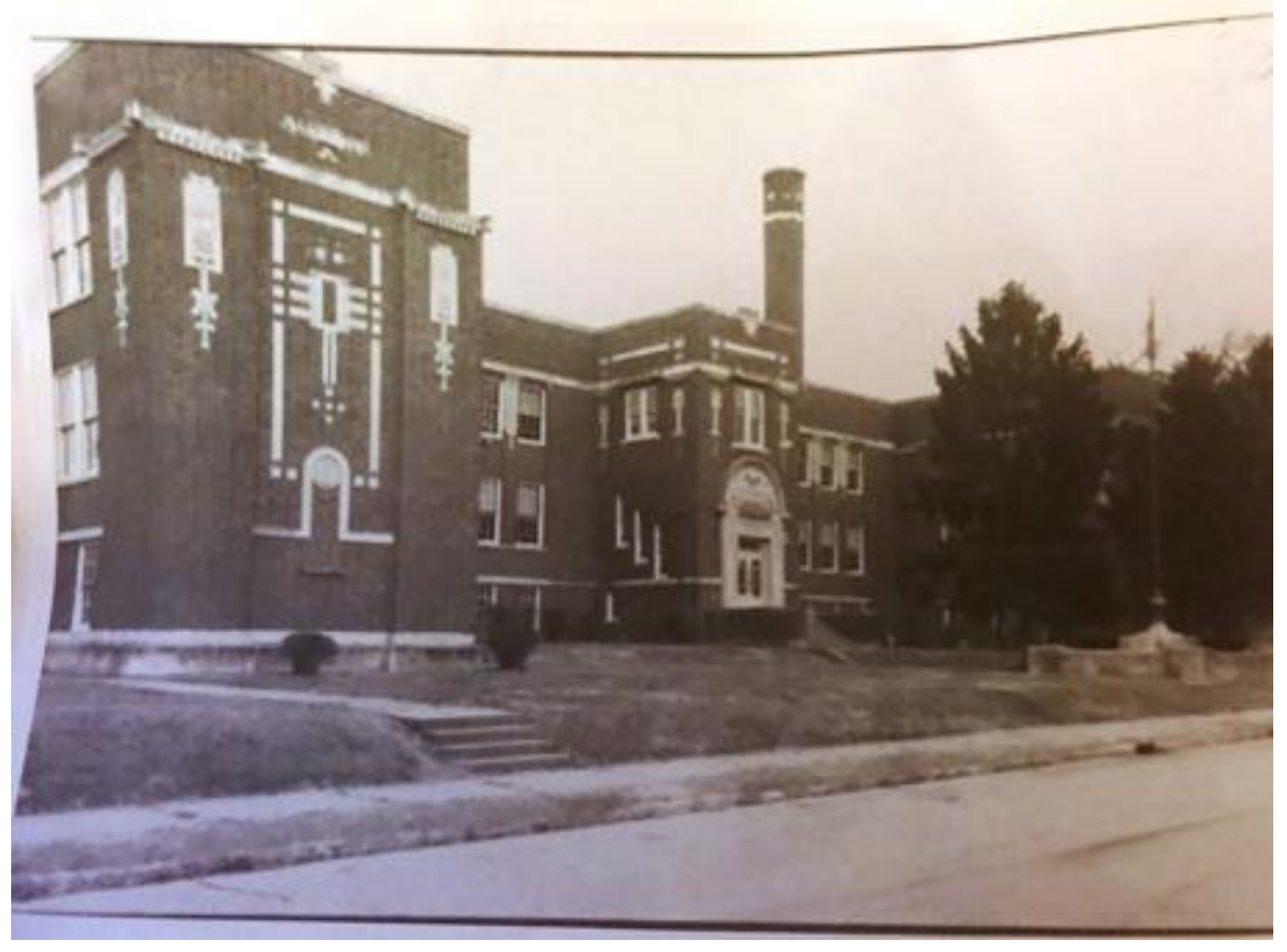

Figure 6. William R. Belknap School. No photo credit given. Jefferson County Public School Archives and Records. 


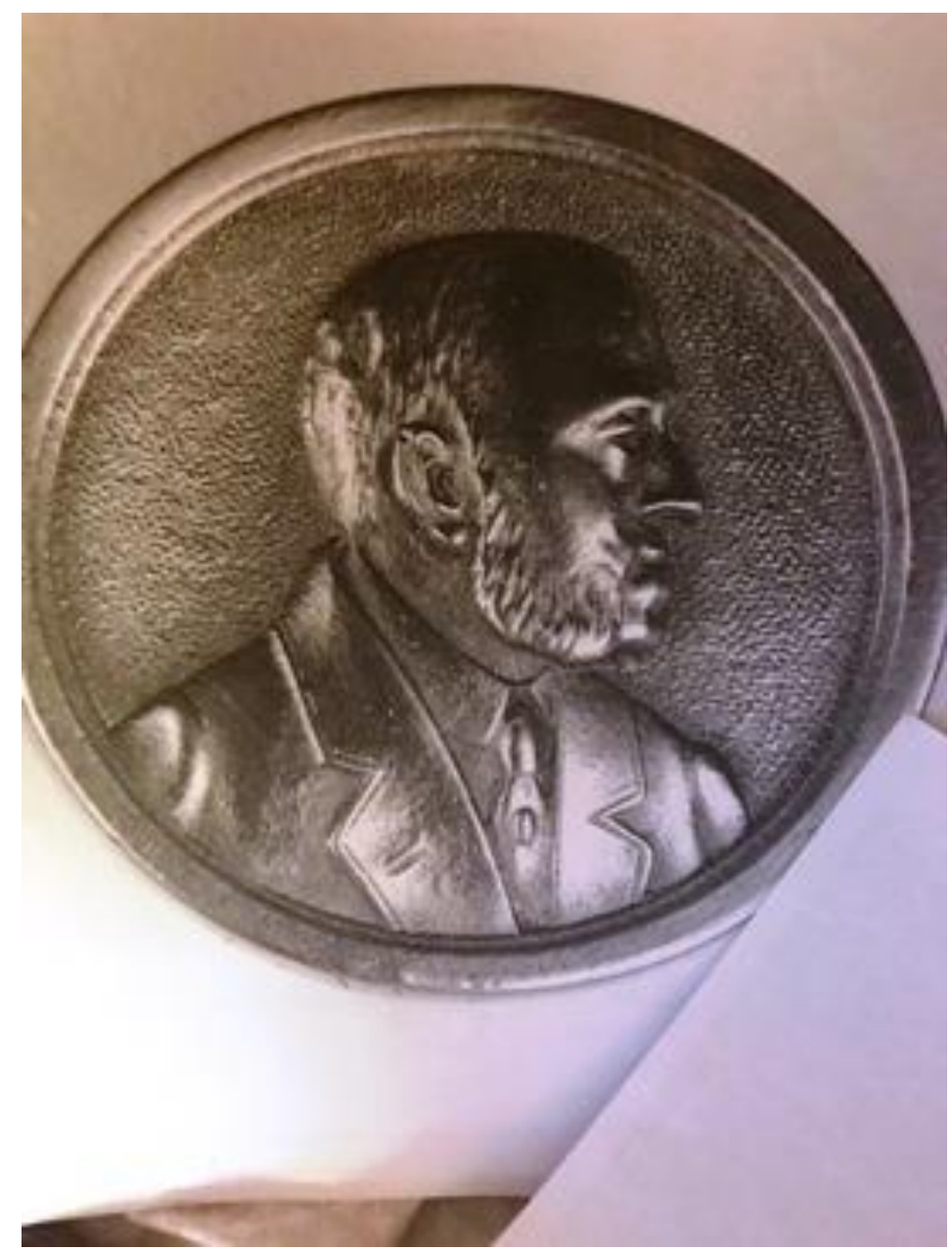

Figure 7. Detail of Doorknob showing profile of William R. Belknap, William R.

Belknap School. No photo credit given. Jefferson County Public School Archives and Records. 


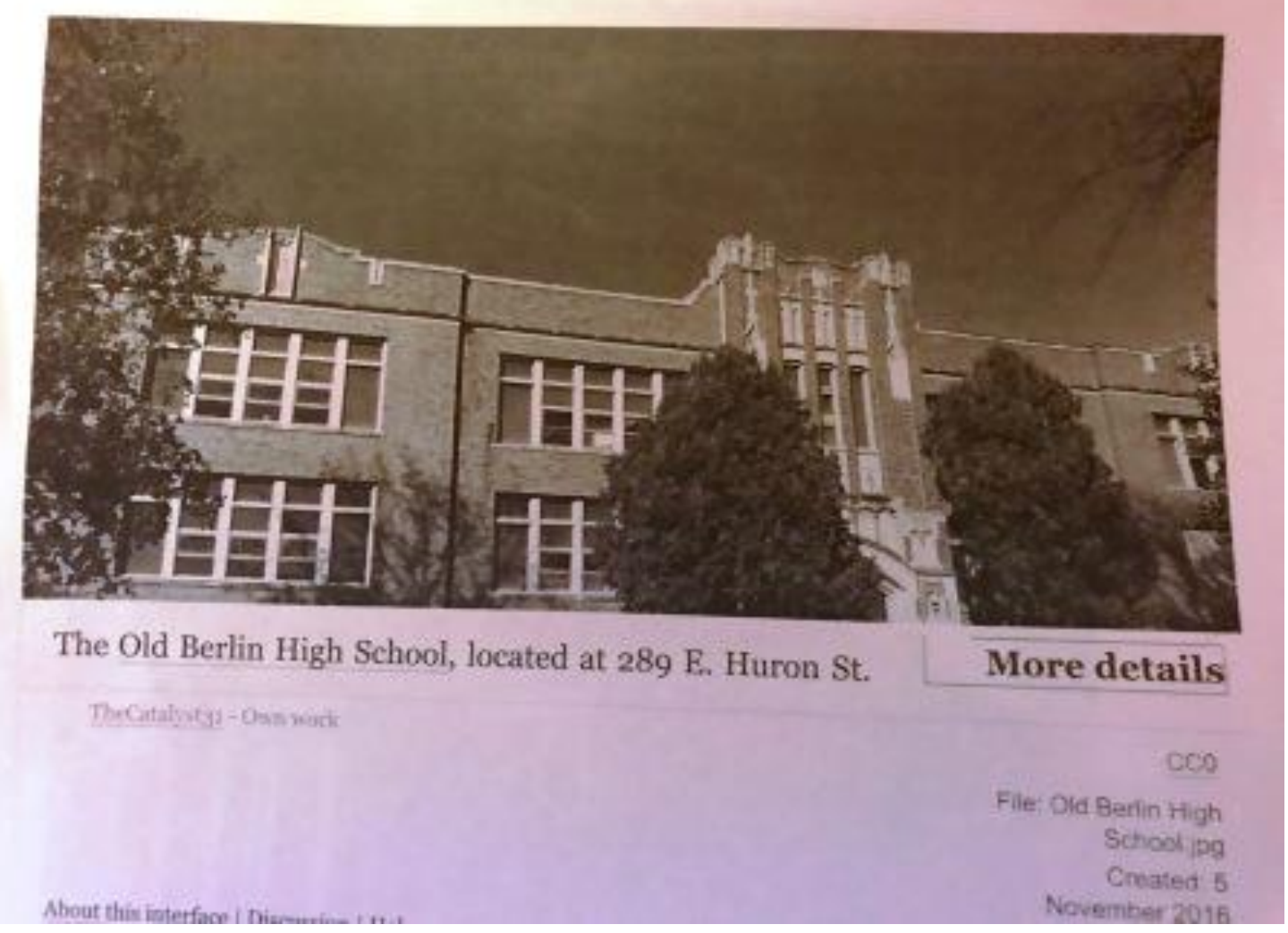

Figure 8. The Old Berlin High School. TheCatalyst31. en.wikipedia.org/wiki/Old_Berlin_High_School\#/media/File:Old_Berlin_High_ School.jpg. 


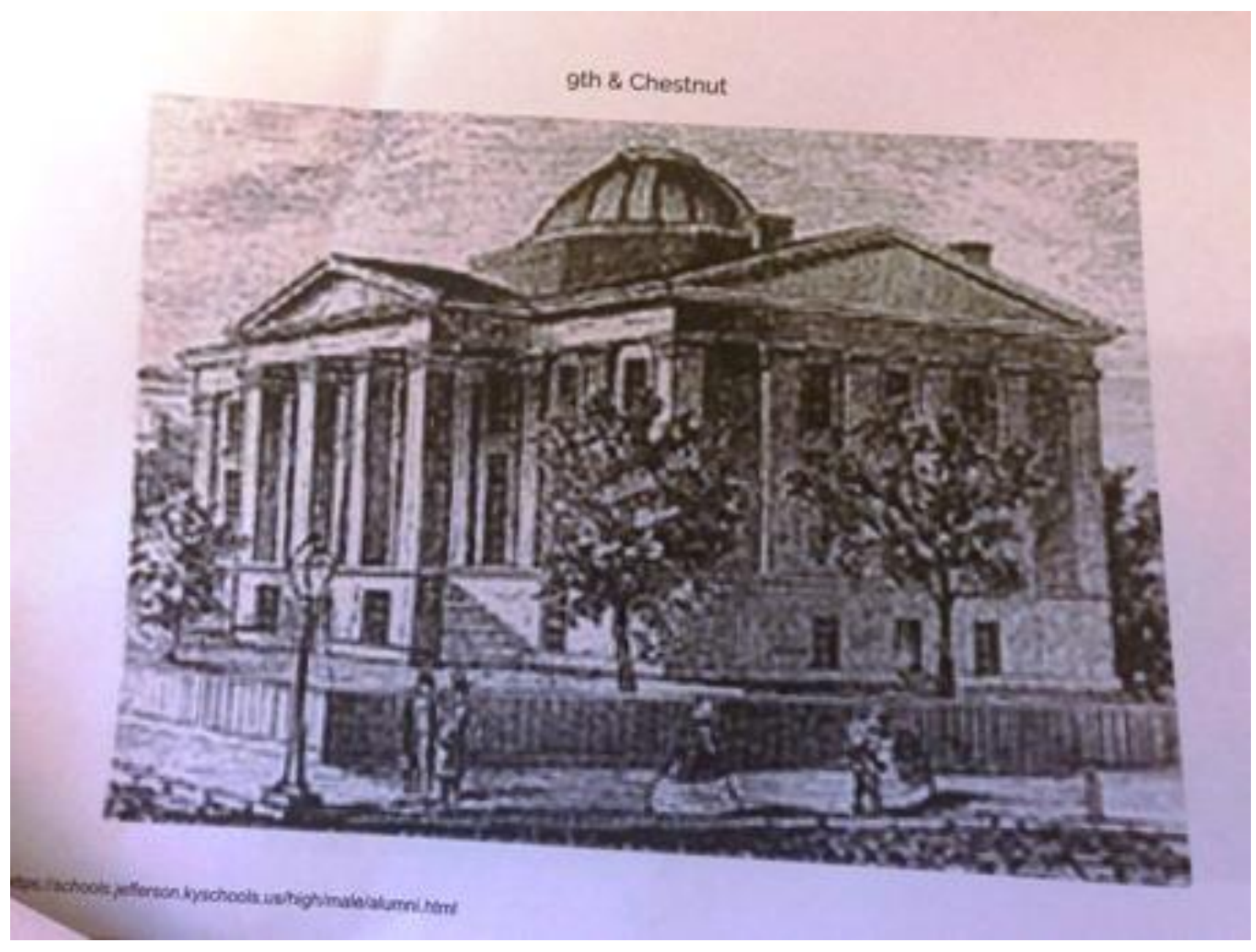

Figure 9. Male High School, $9^{\text {th }}$ and Chestnut Streets. No photo credit given. https://schools.jefferson.kyschools.us/high/male/alumni.html. 


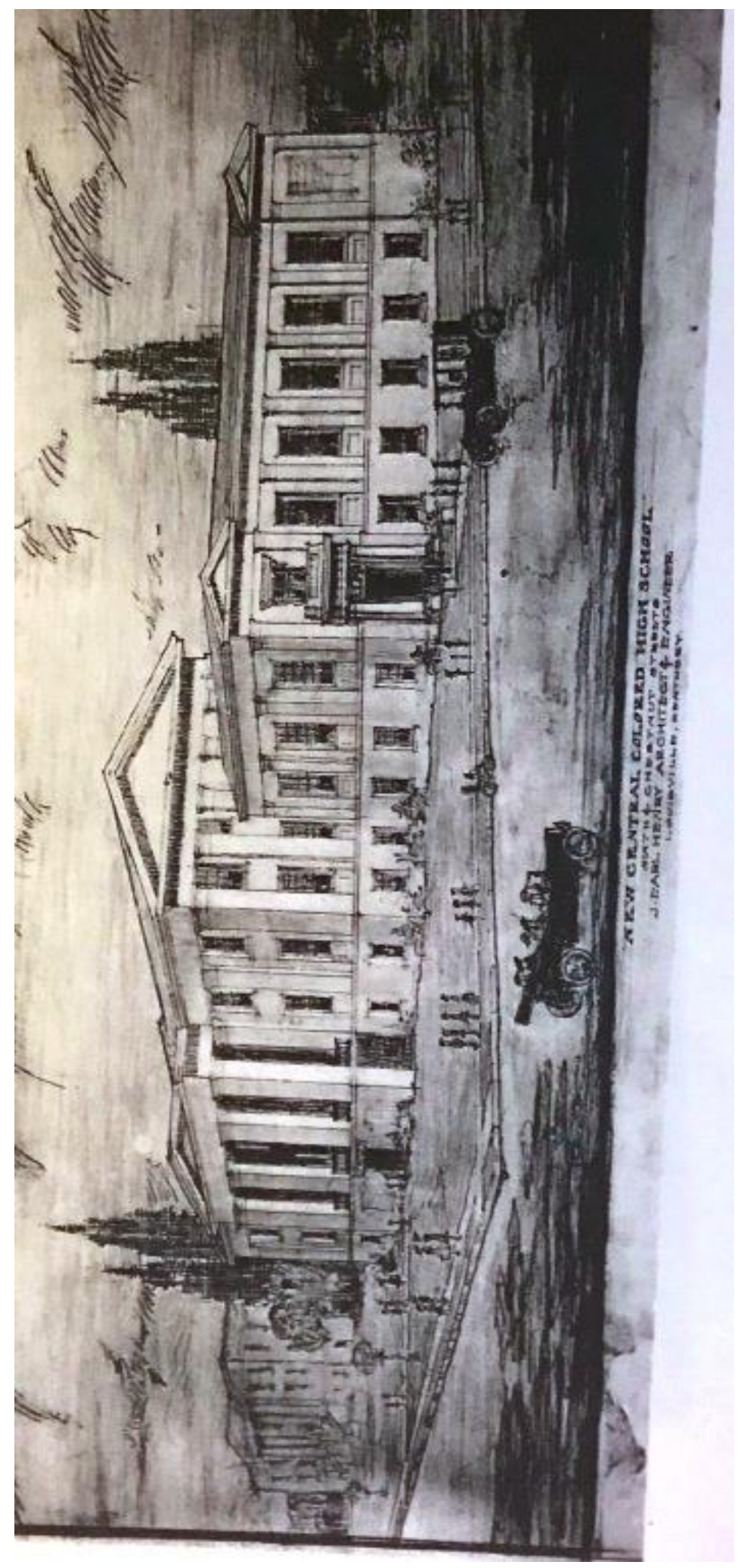

Figure 10. New Central Colored High School Rendering. No photo credit given. Jefferson County Public School Archives and Records. 


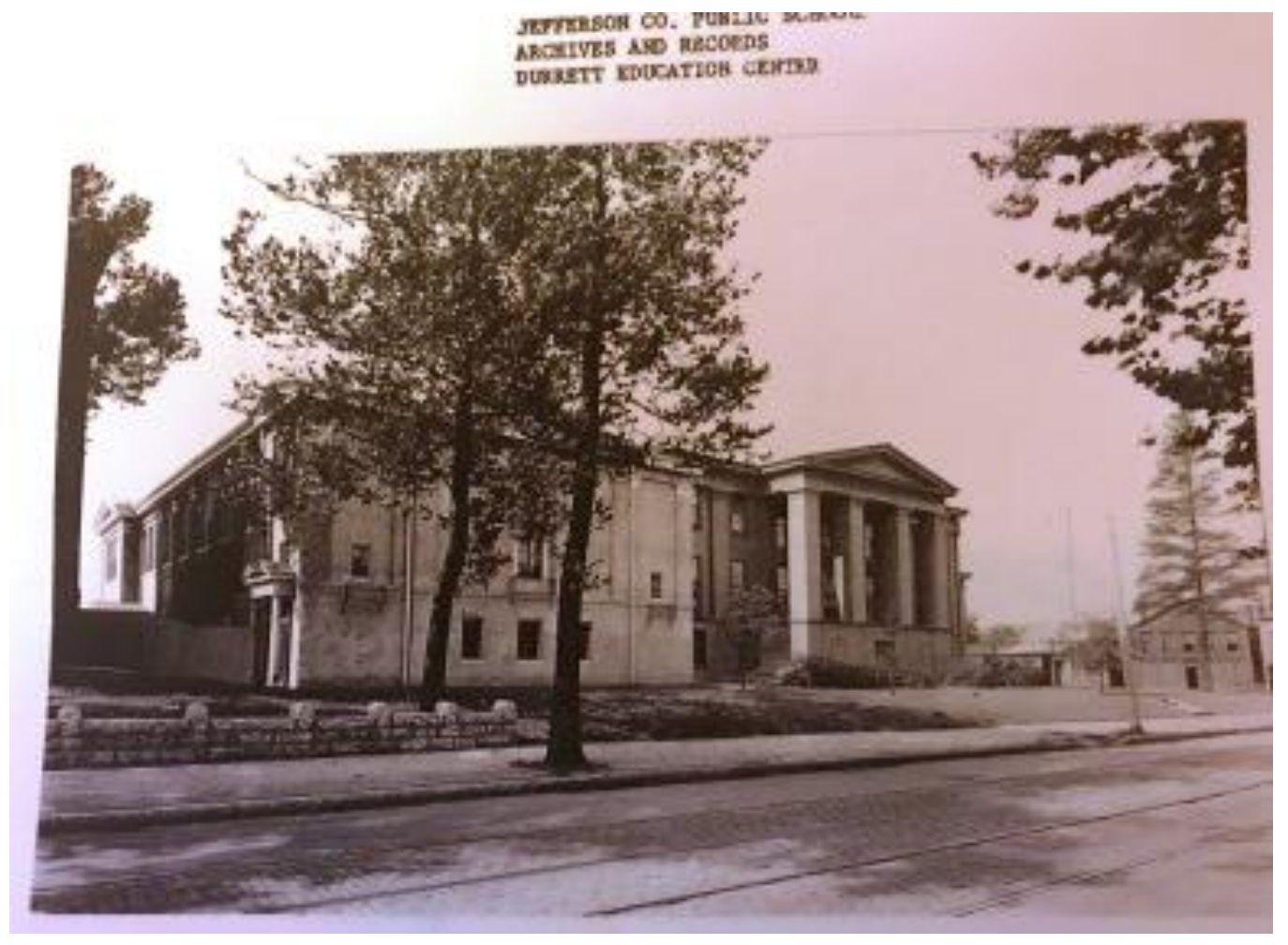

Figure 11. Central High School. No photo credit given. Jefferson County Public School Archives and Records. 


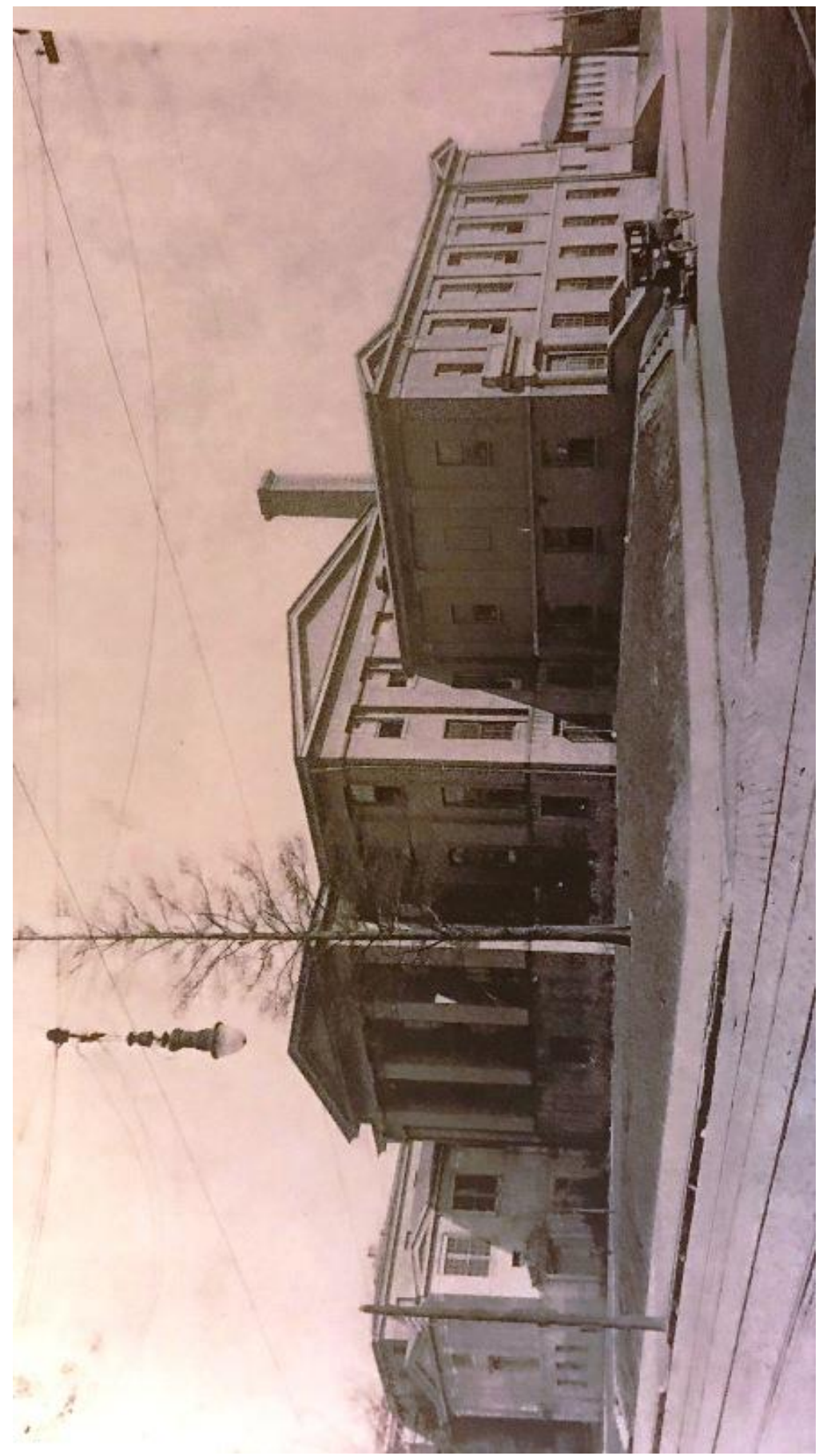

Figure 12. Central High School. No photo credit given. Jefferson County Public School Archives and Records. 


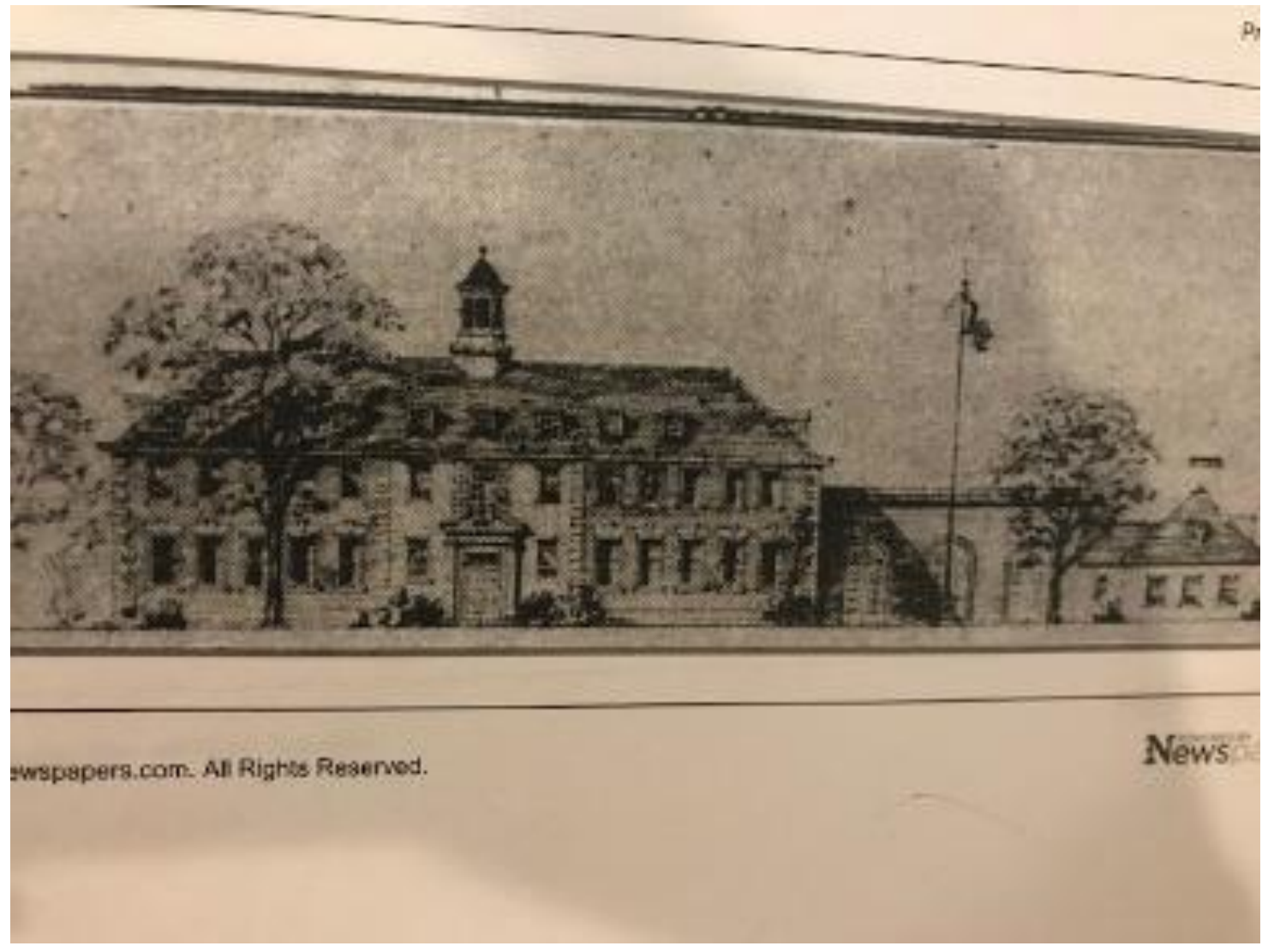

Figure 13. Louisville Collegiate School Rendering. No photo credit given. www.newspapers.com/images/107813114/?terms=nevin\%2Band\%2Bmorgan. 


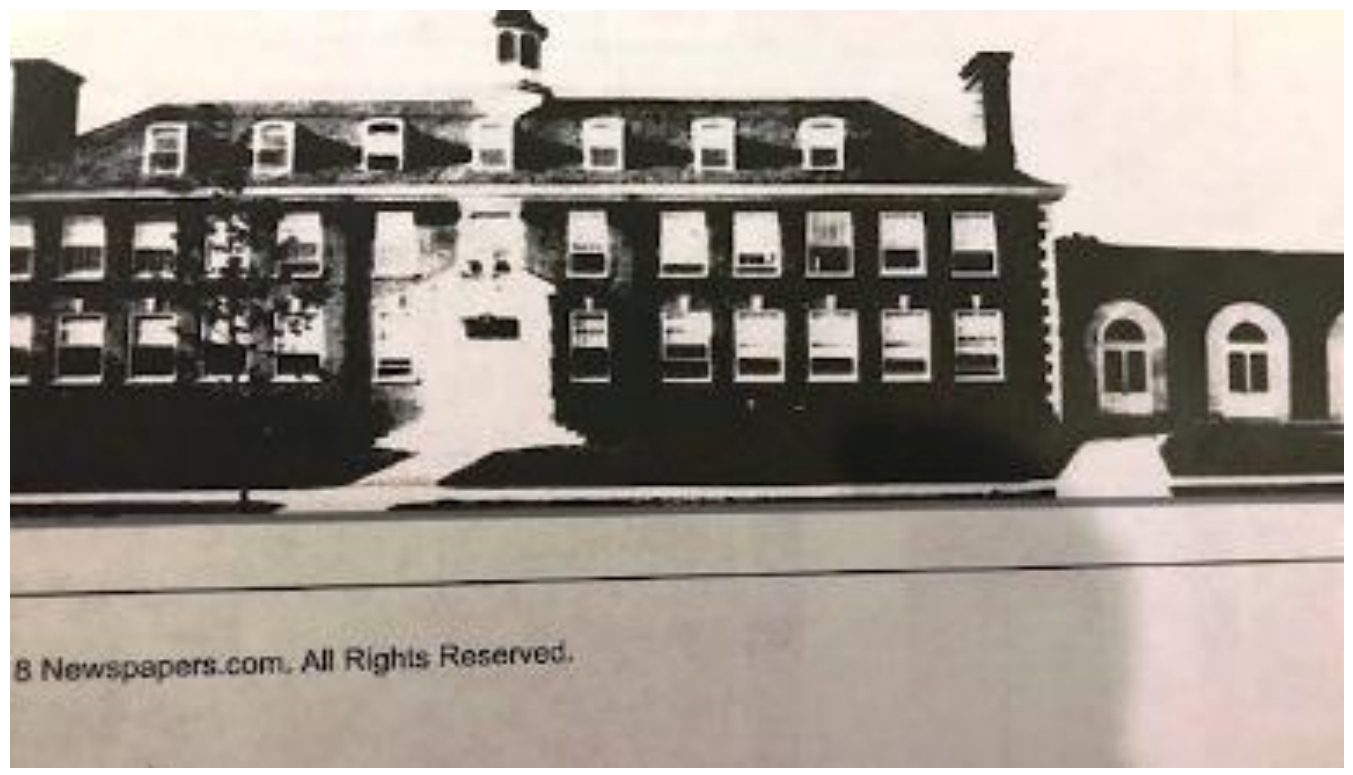

Figure 14. Louisville Collegiate School. No photo credit given. www.newspapers.com/image/107116493/?terms=nevin\%2Band\%2Bmorgan. 


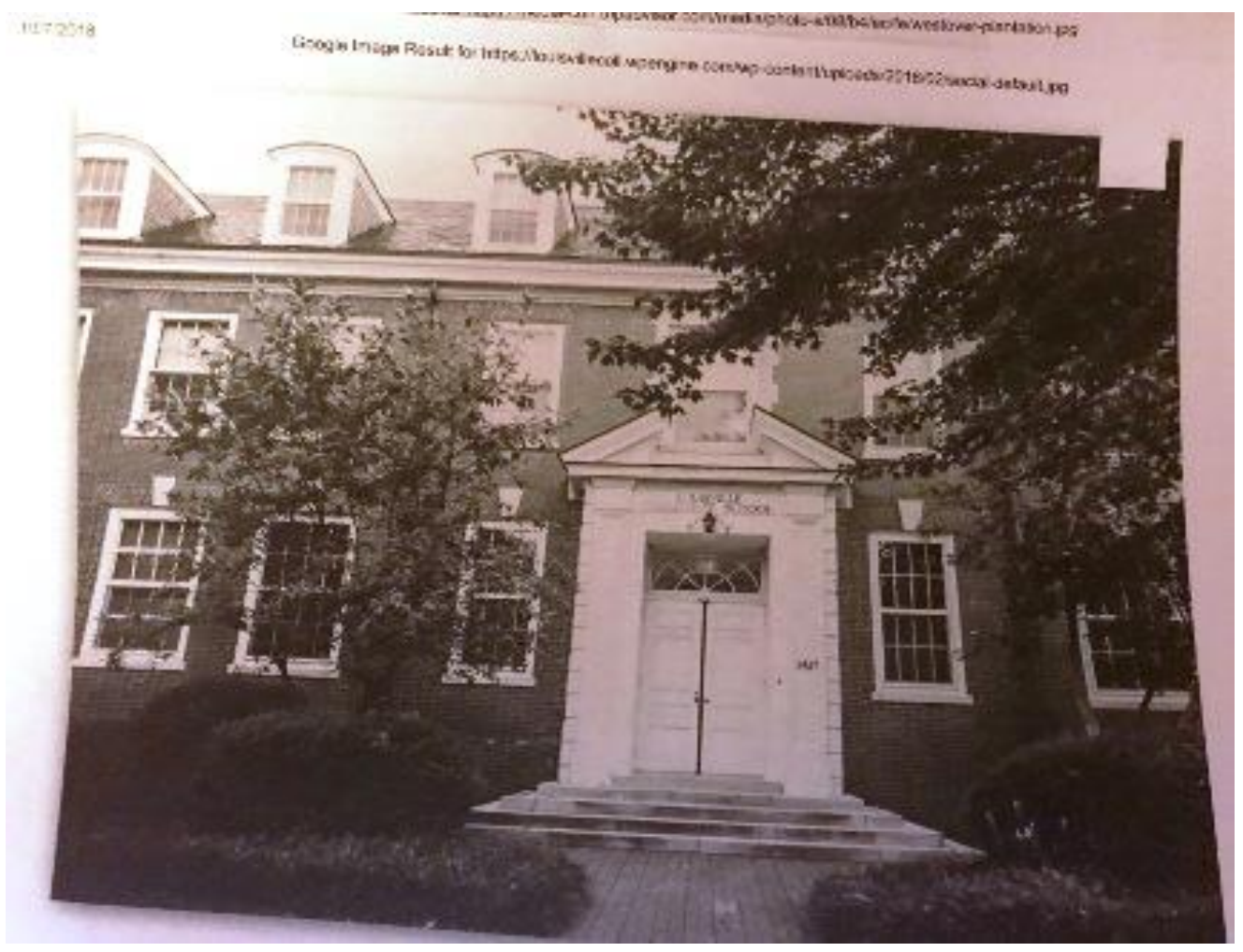

Figure 15. Louisville Collegiate School Main Entrance. No photo credit given. www.niche.com/k12/louisville-collegiate-school-louisville-ky/. 

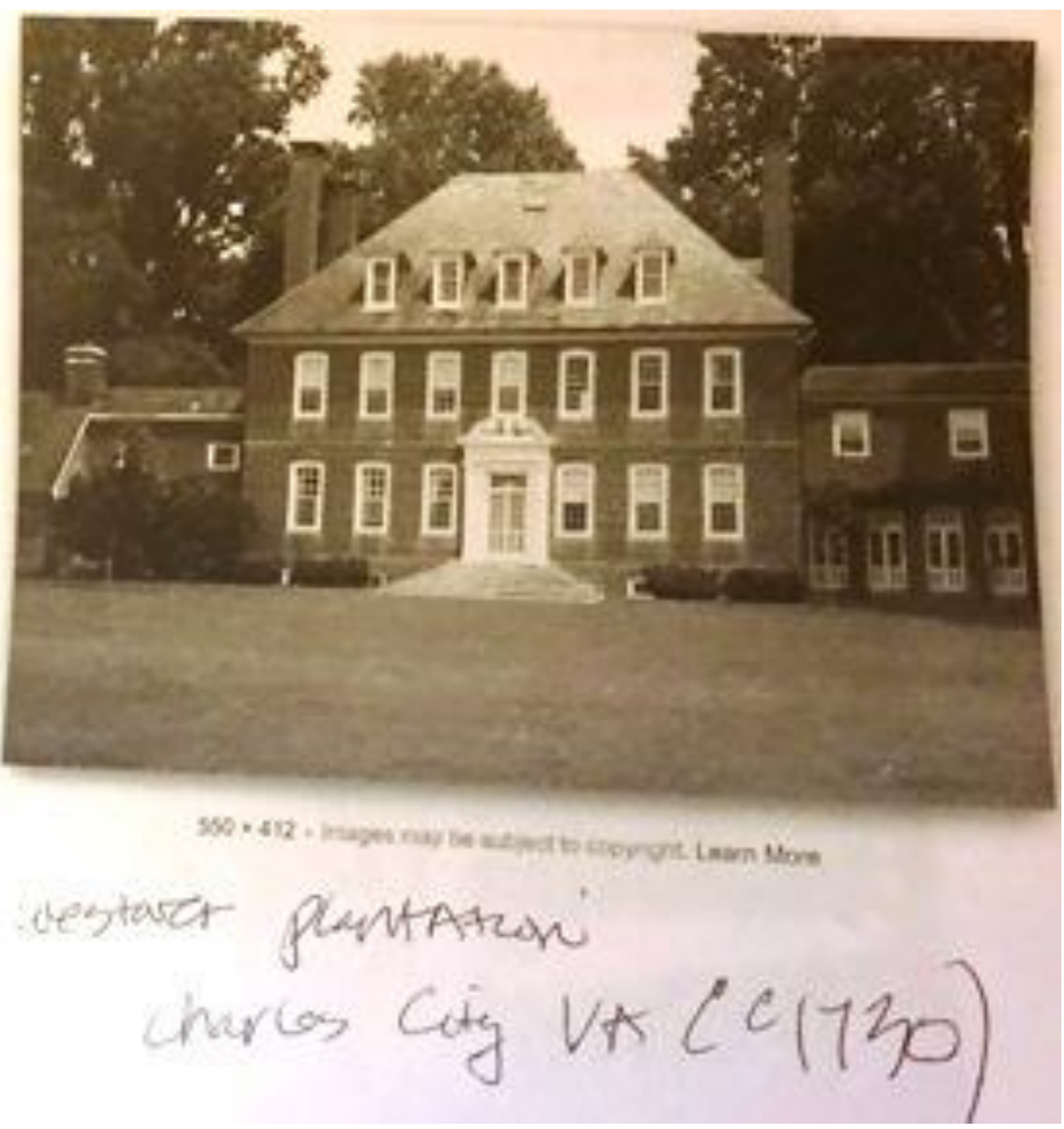

Figure 16. Westover Plantation. No photo credit given.

www.tripadvisor.com/LocationPhotoDirectLink-g57590-d564109-i146074878-

Westover_Plantation-Charles_City_Virginia.html. 


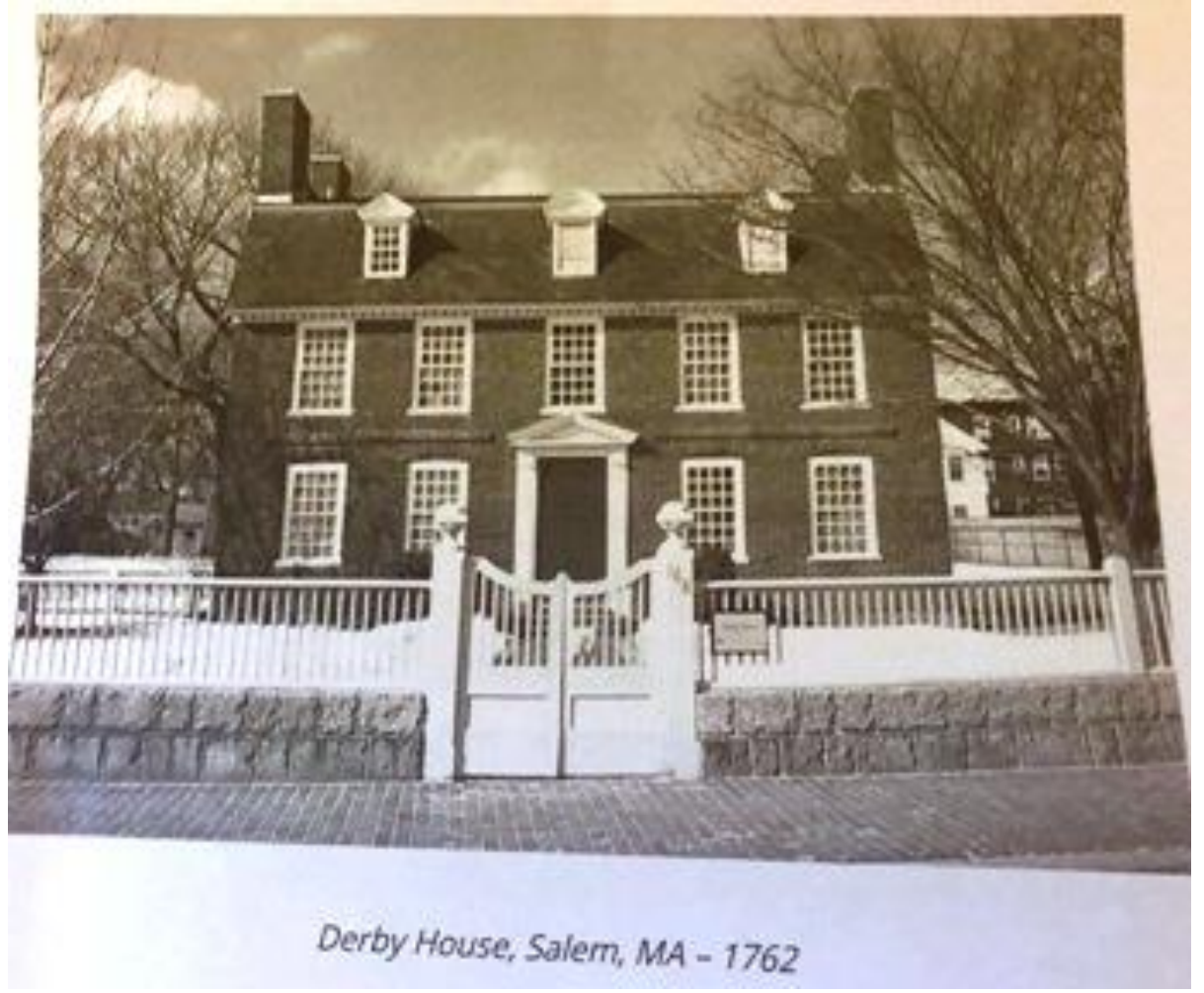

Figure 17. Derby House, Salem, MA. Meredith Both Interior design. mlbinteriordesign.com. 


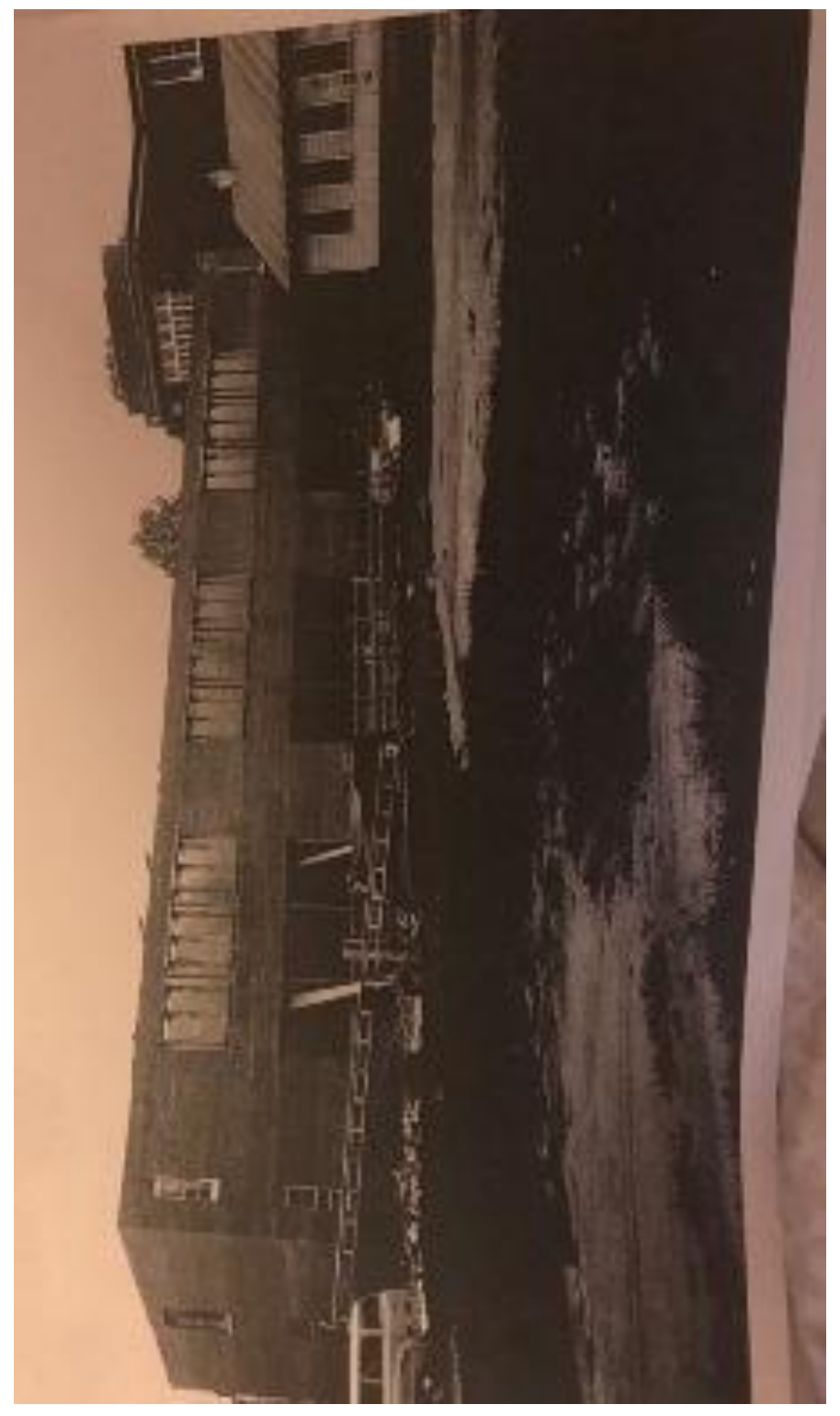

Figure 18. J. B. McFerran School addition. No photo credit given. Jefferson County Public School Archives and Records. 


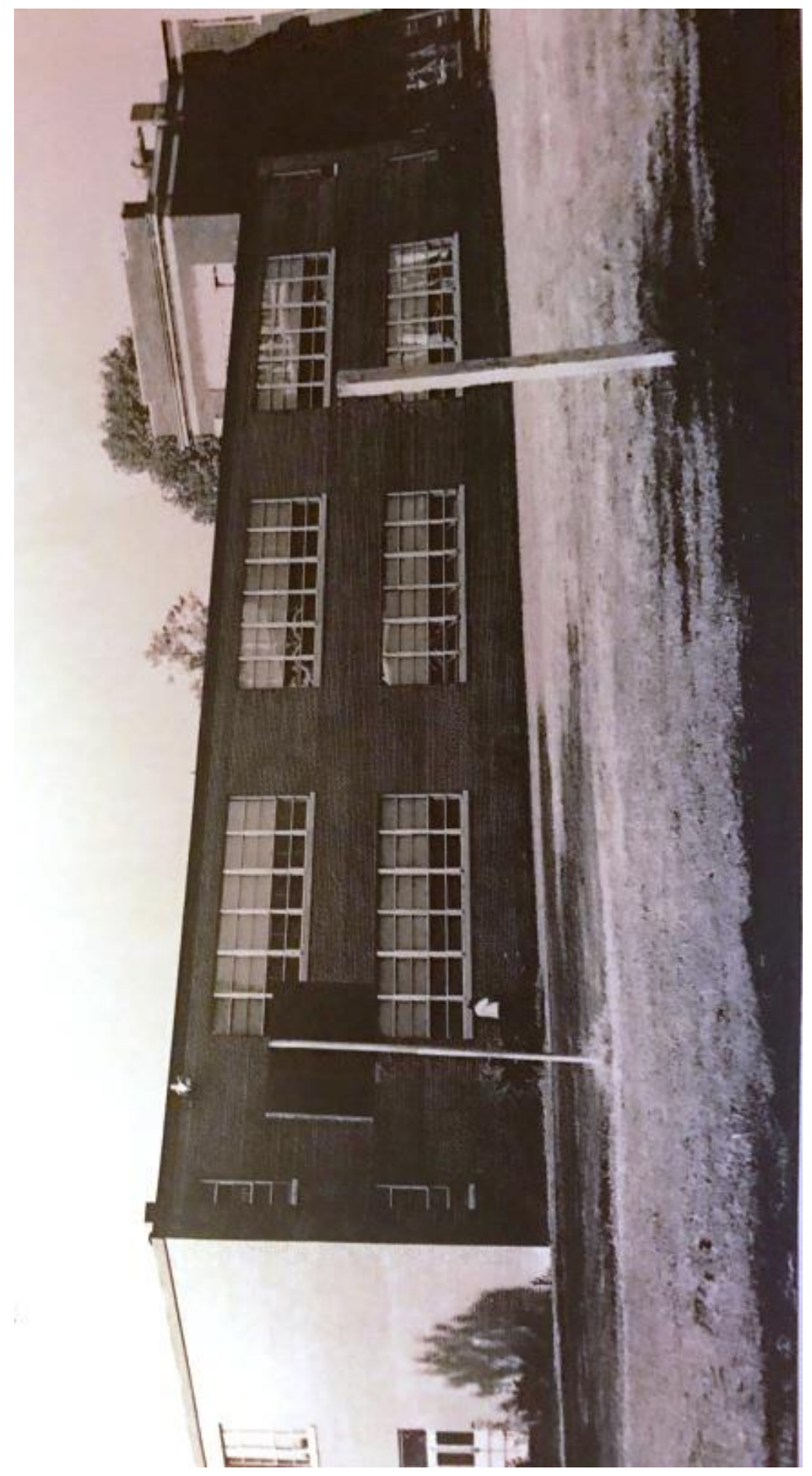

Figure 19. J. B. McFerran School. No photo credit given. Jefferson County Public School Archives and Records. 


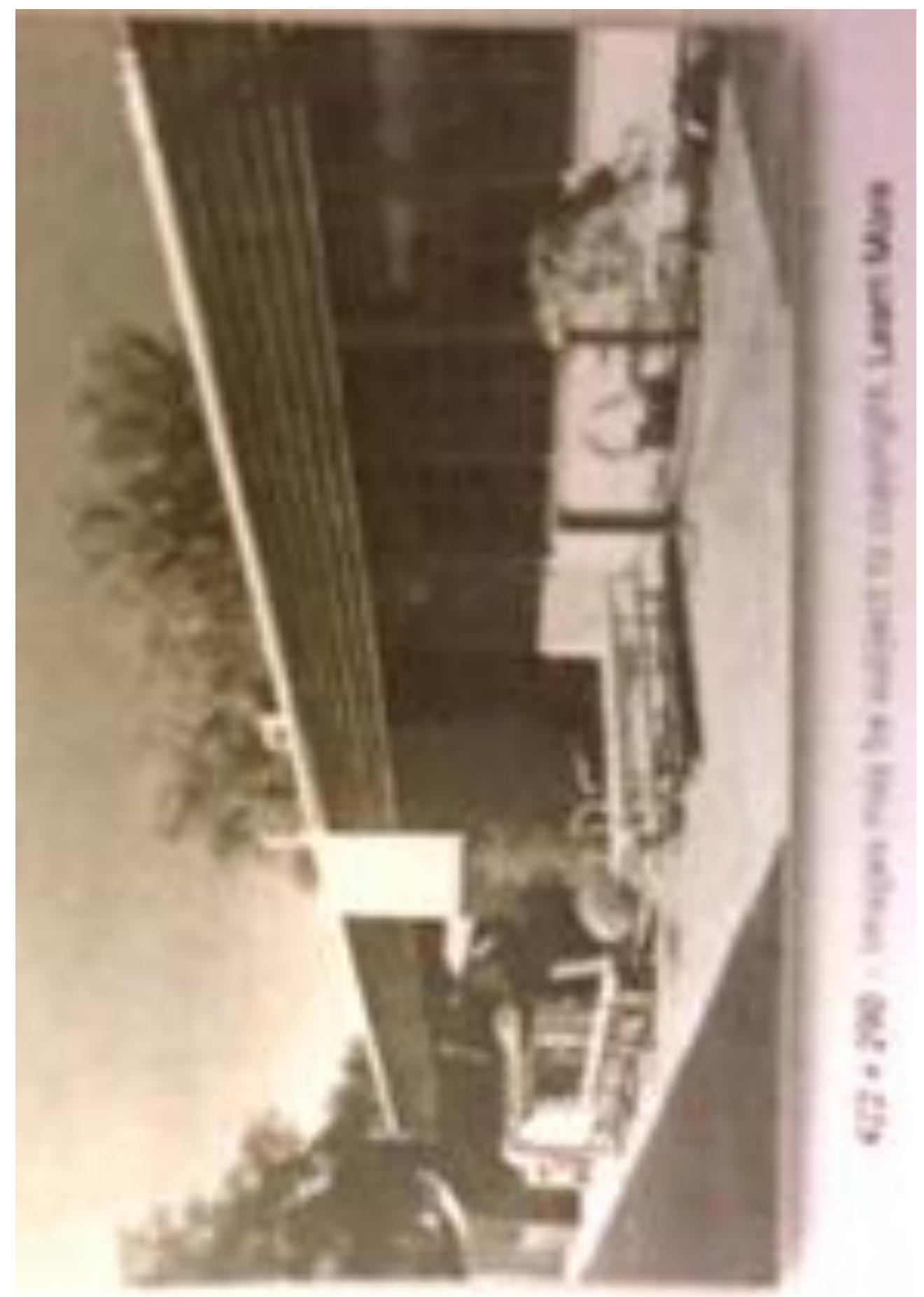

Figure 20. Kester Street Elementary School. No photo credit given. www.whalerjack.com. 


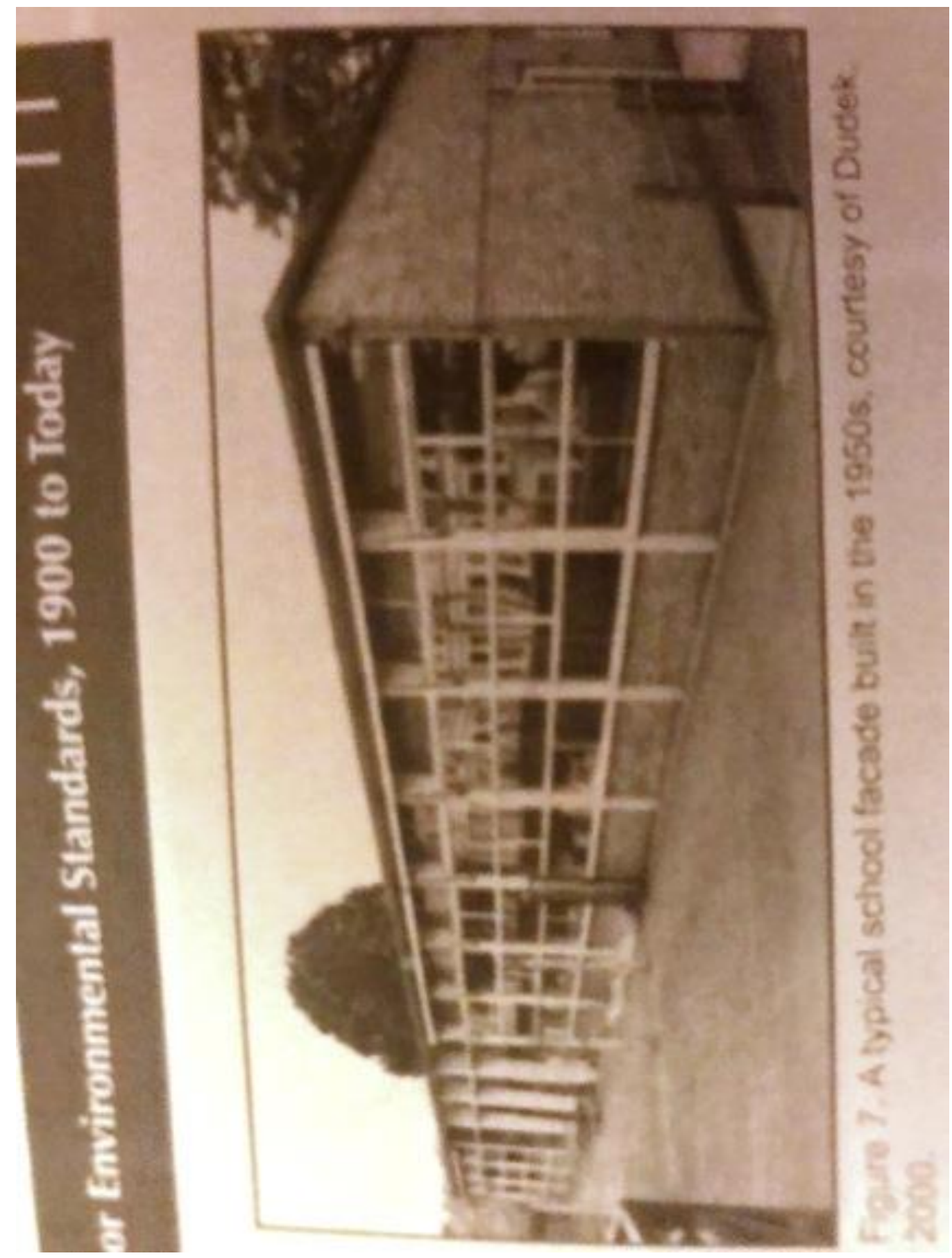

Figure 21. Typical 1950s School. Dudek, 2000. www.ncef.org. 


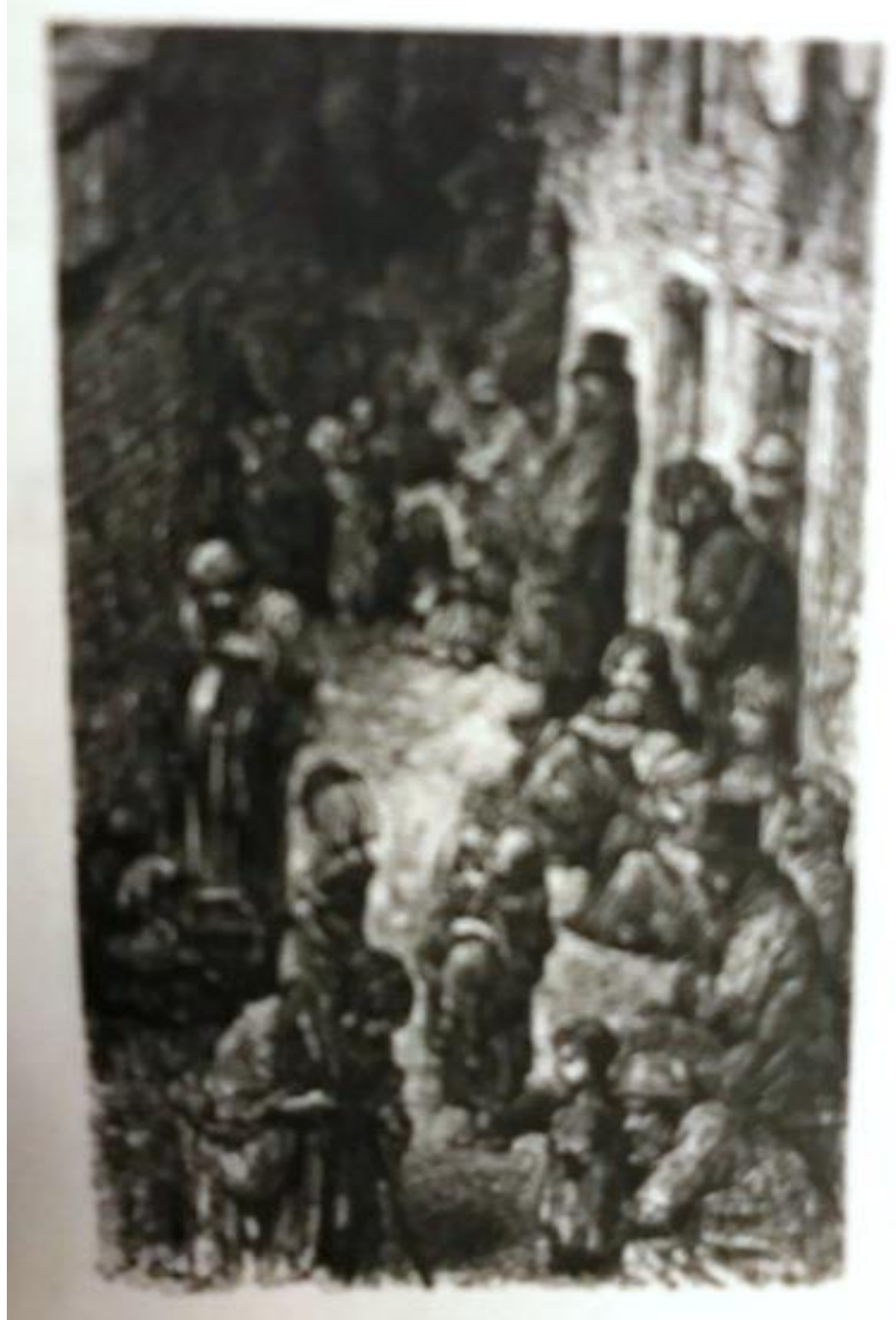

Figure 22. Industrial Revolution Housing. No photo credit given.

webs.bcp.org/sites/vcleary/modernworldhistorytextbook/ industrialrevolution/ireffects.html3livingconditions. 


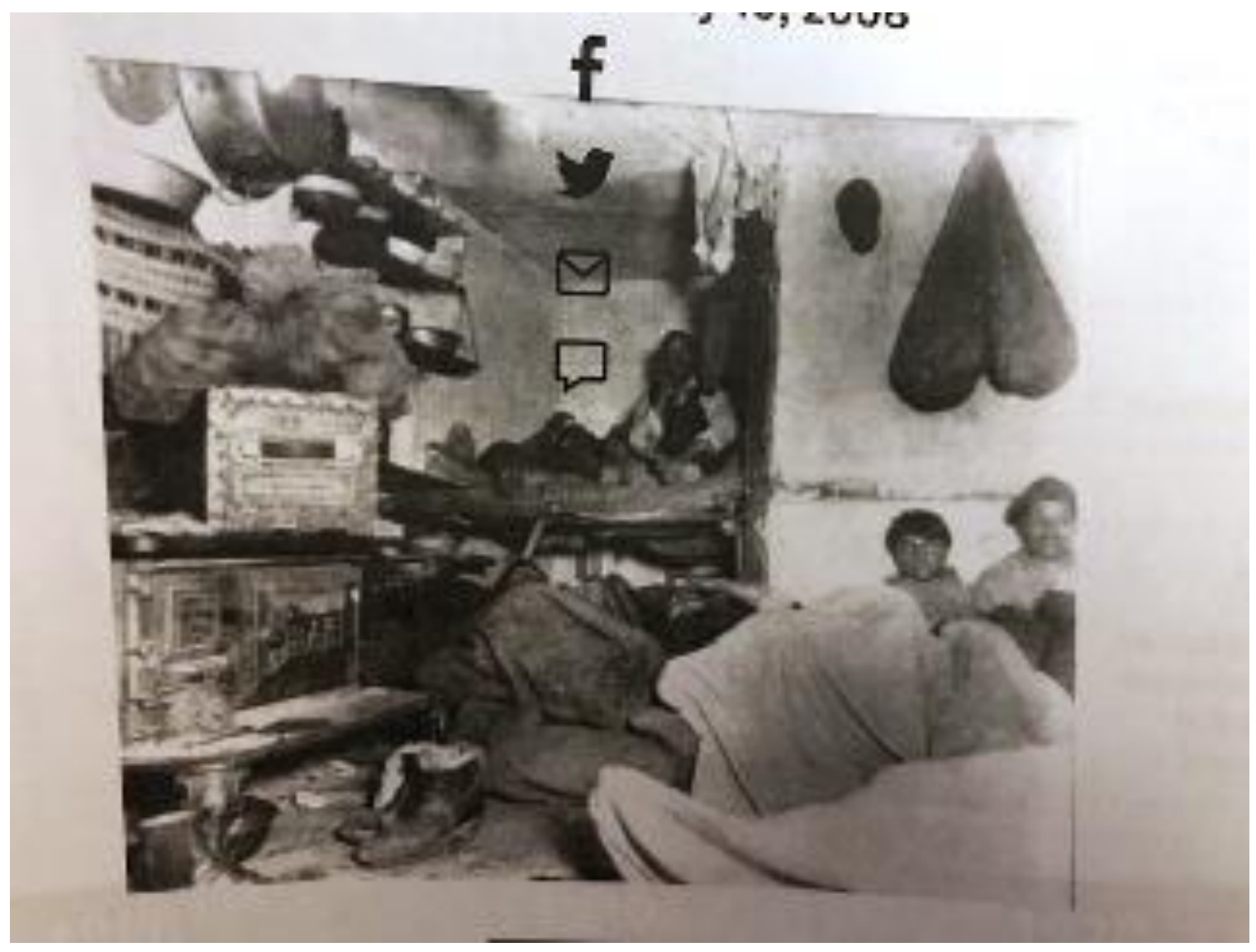

Figure 23. New York Boarding House in 1889. Jacob Riis. Published in Rediscovering Jacob Riis: Exposure Journalism and Photography in Turn-of-the-Century New York. New York: New Press, 2007. 


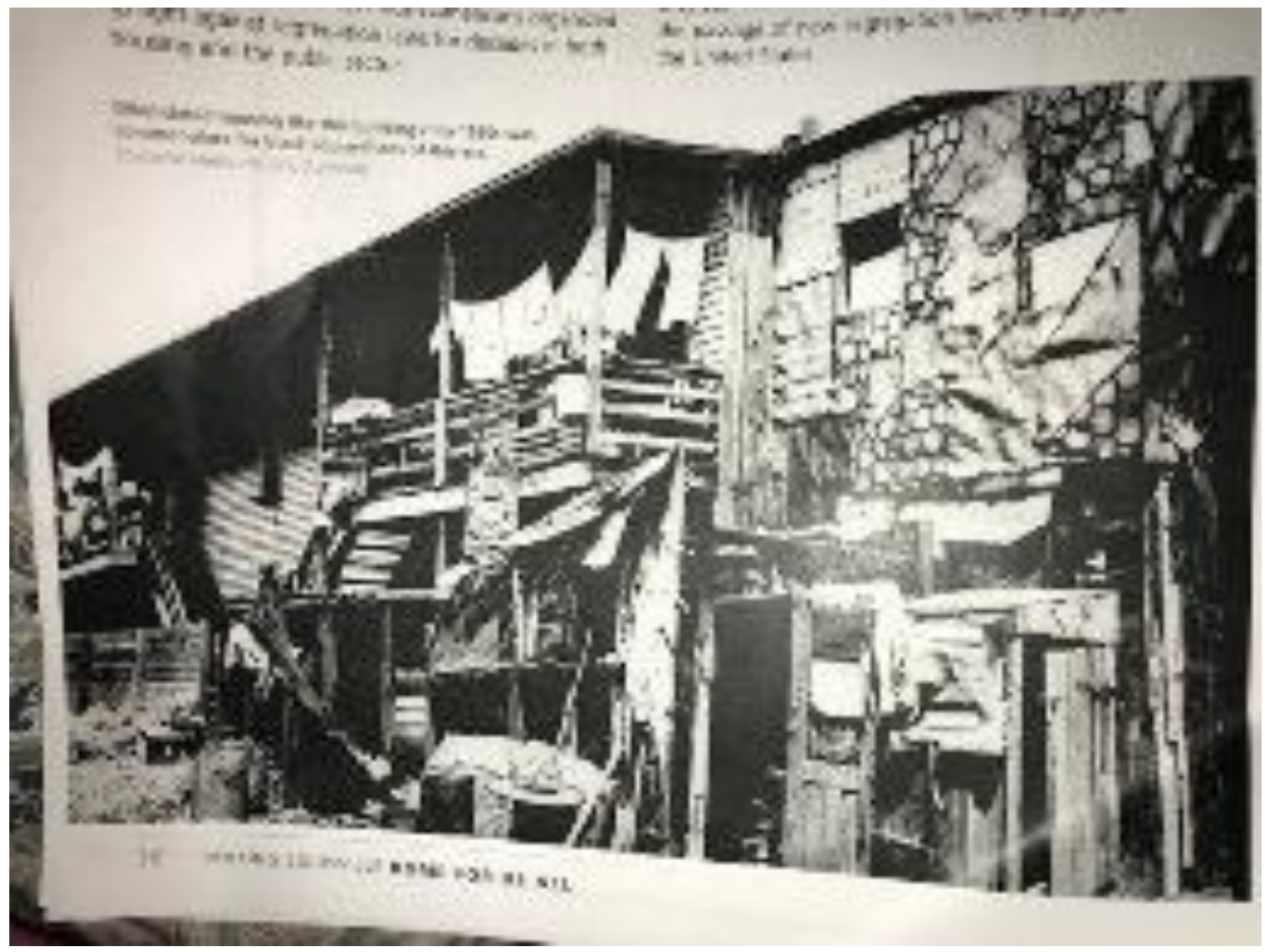

Figure 24. Housing at 731 Marshall Street. Louisville Metro Housing Authority. Published in Making Louisville Home for Us All, 2013. 


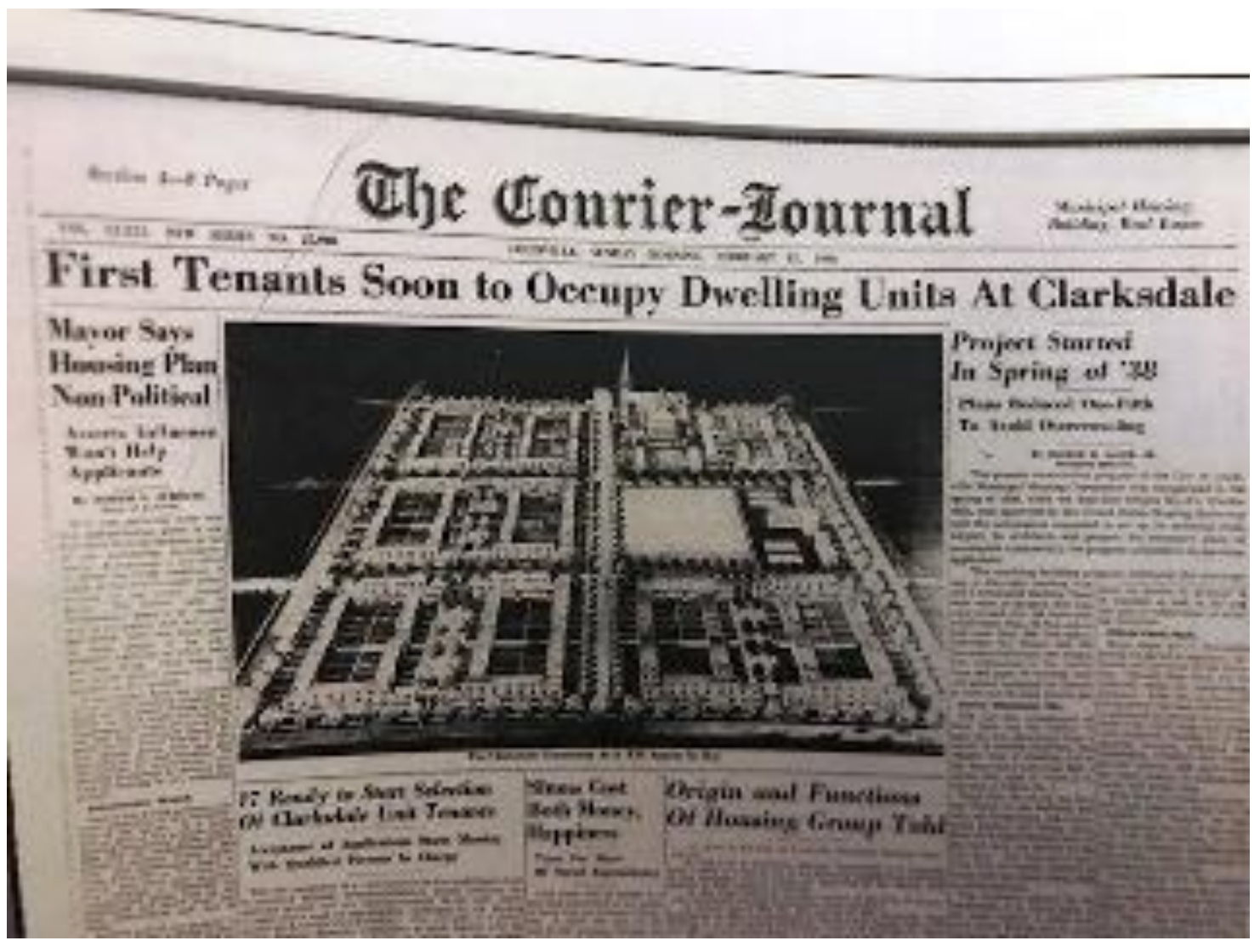

Figure 25. Clarksdale Housing birds-eye view. No photo credit given. The Courier-

Journal. Sunday, February 25, 1940. www.newspapers.com. 


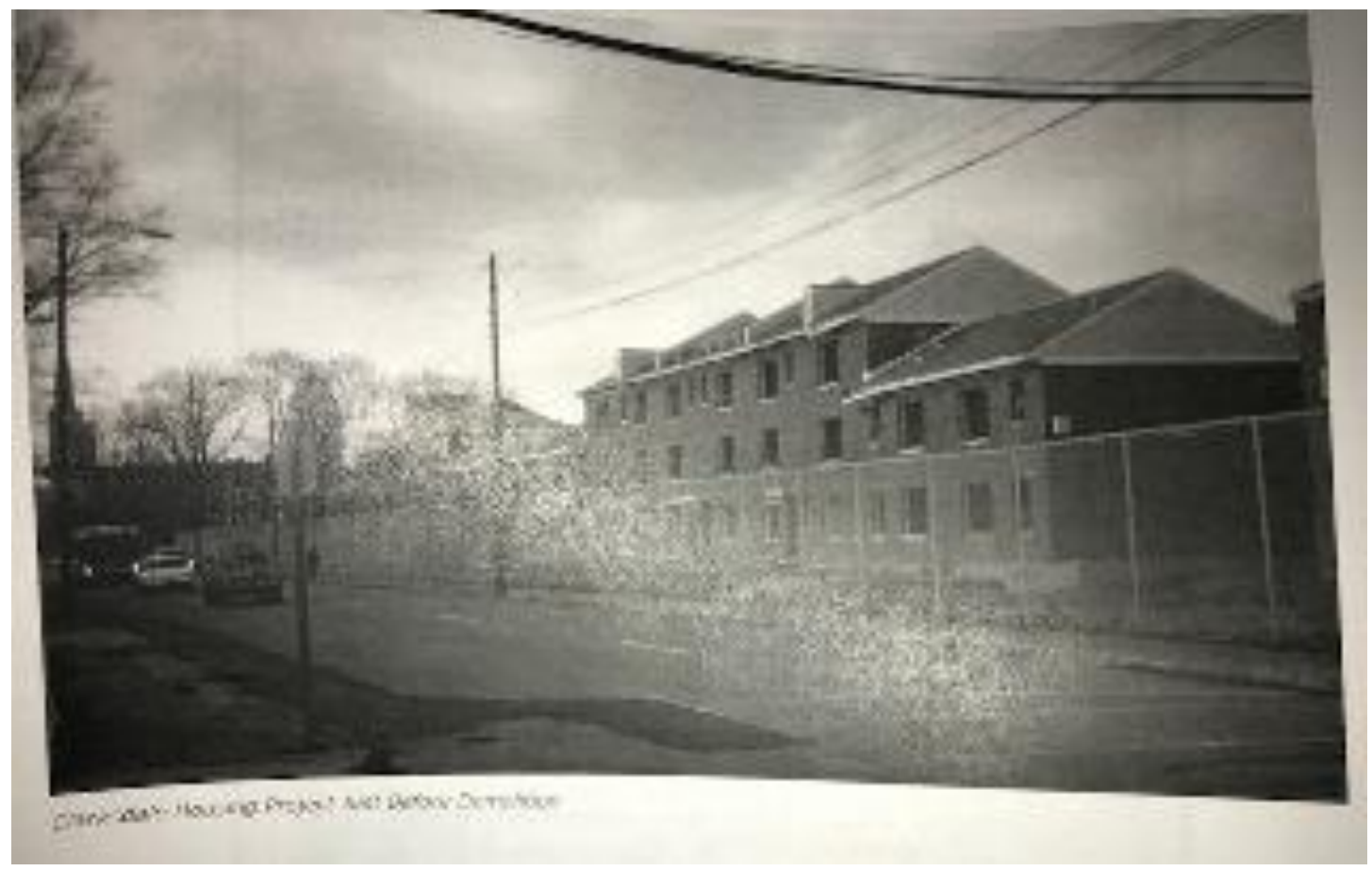

Figure 26. Clarksdale Housing project. No photo credit given.

brokensidewalk.com/2009/what-is-a-housing-project/ 


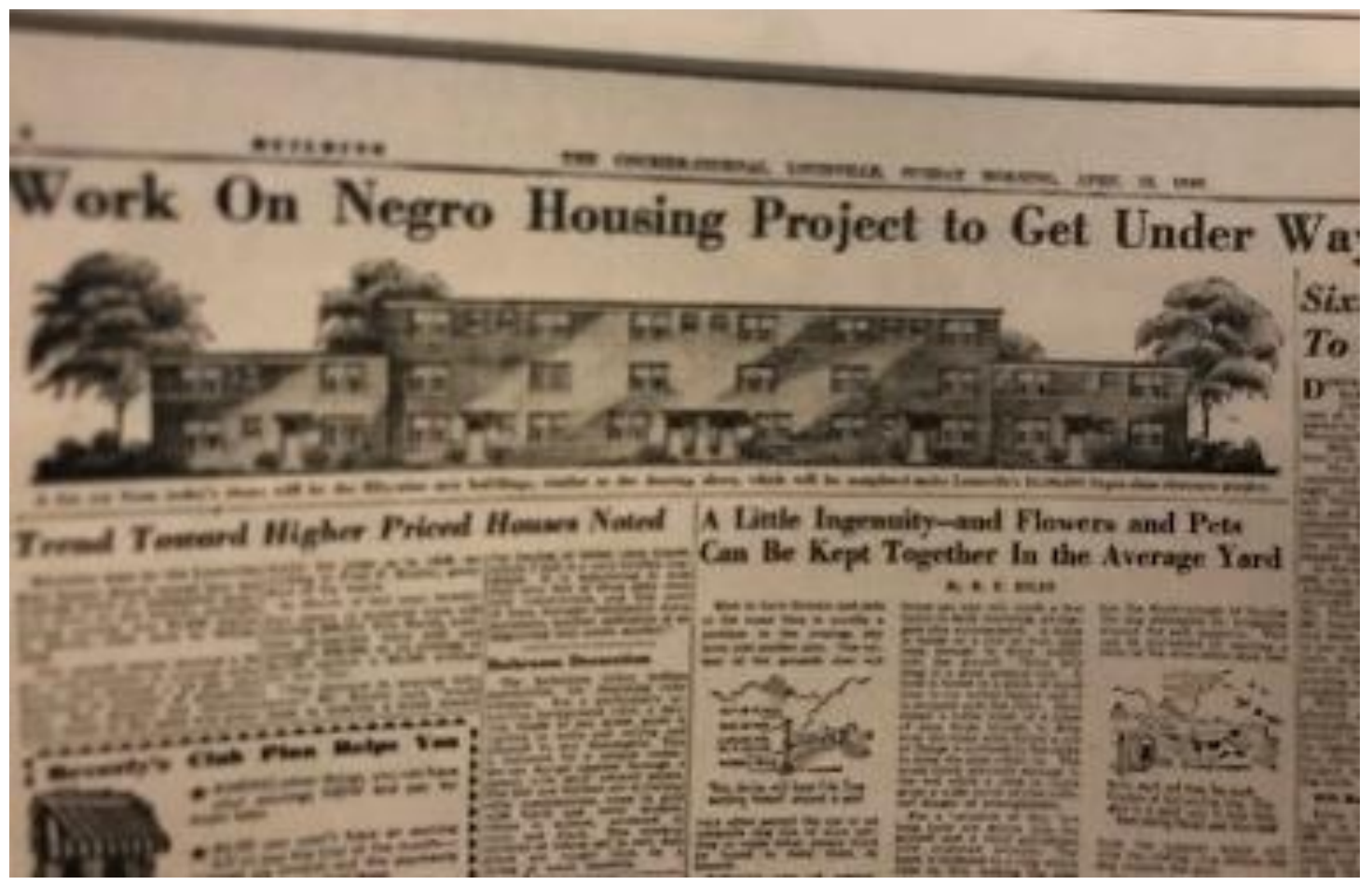

Figure 27. Beecher Terrace Housing Project rendering. No photo credit given. The Courier-Journal, Sunday, April 16, 1939. www.newpapers.com. 


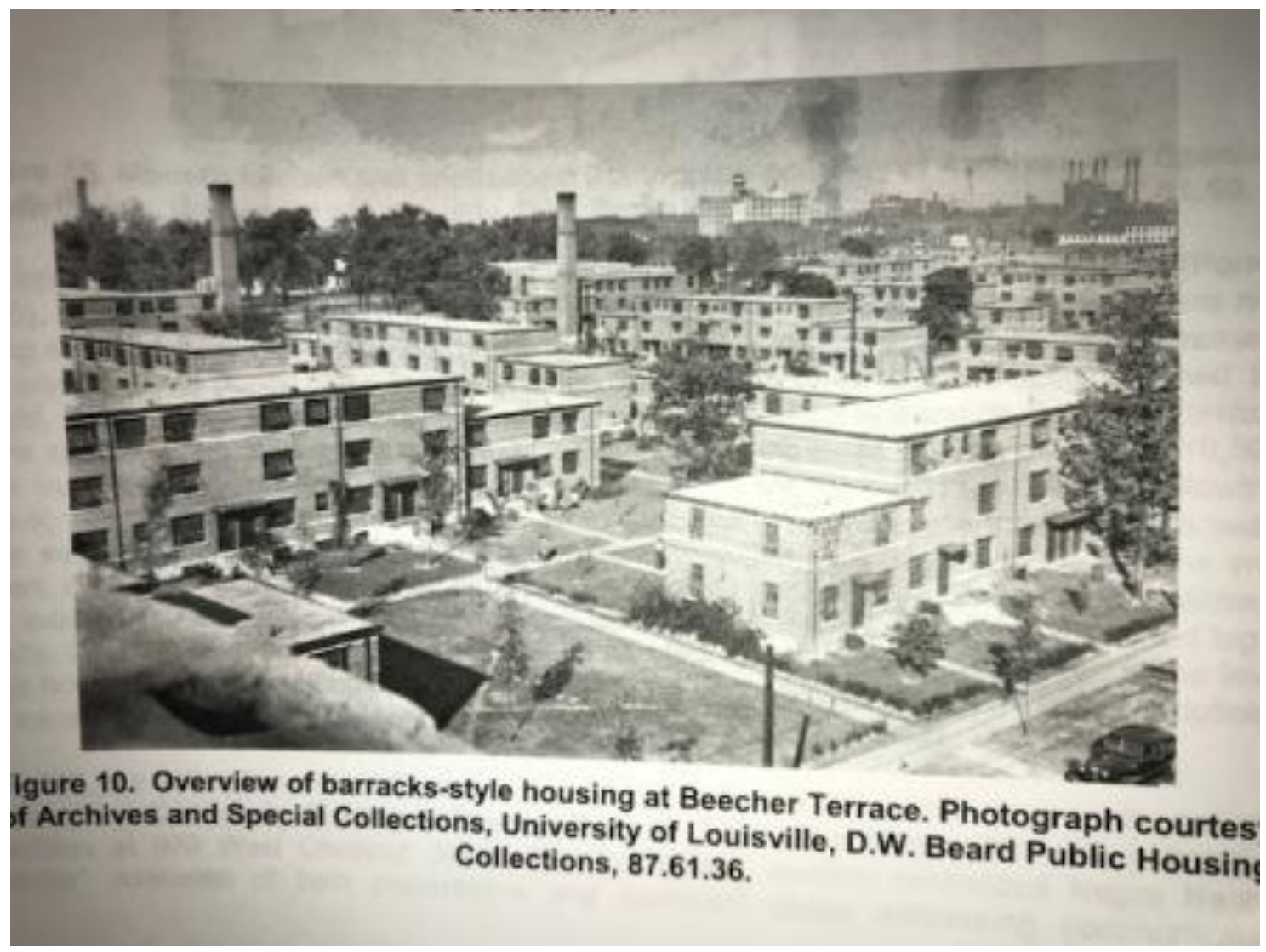

Figure 28. Beecher Terrace Overview. Archives and Special Collections, University of Louisville, D. W. Beard Public Housing Collections, 87.61.36. 


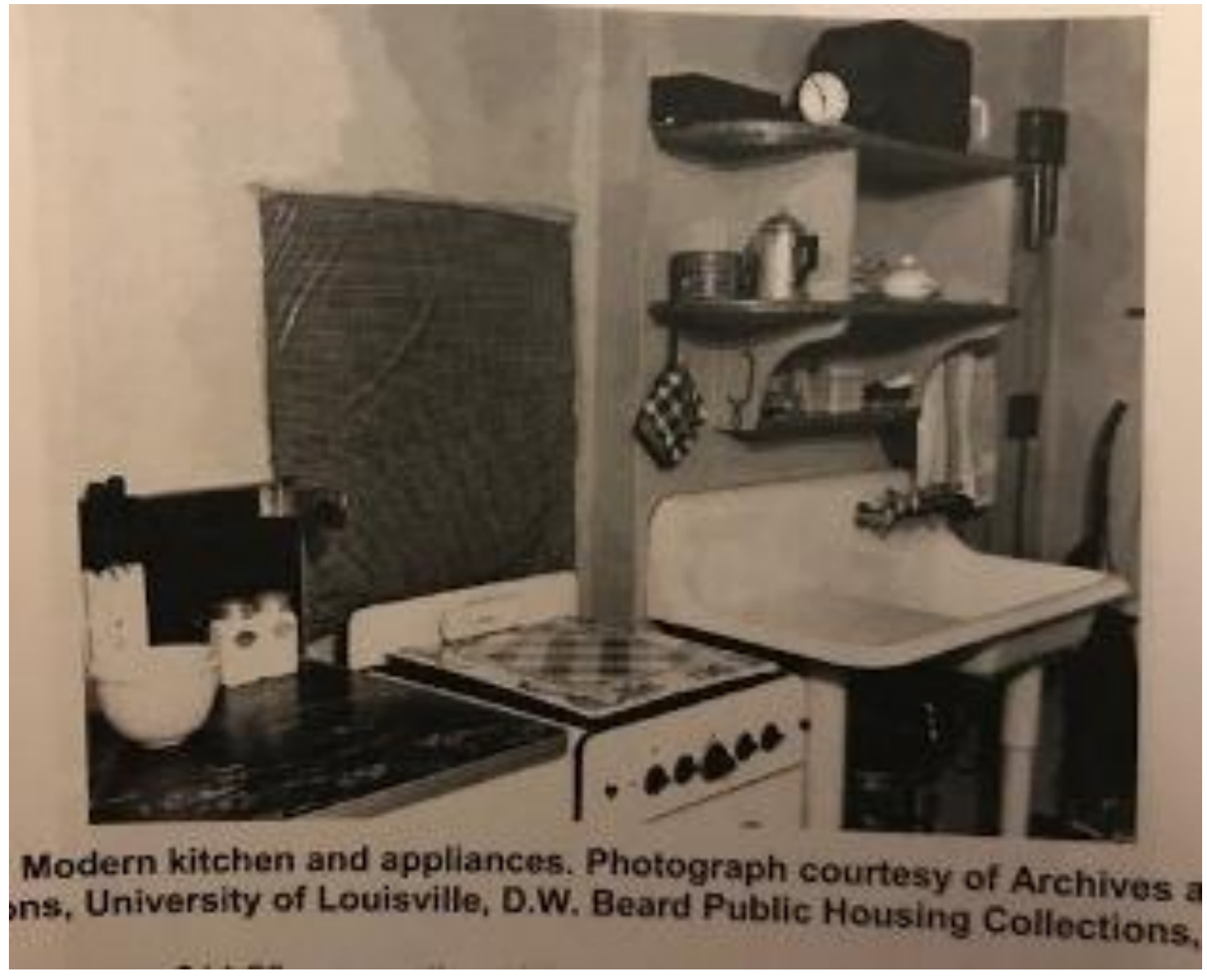

Figure 29. Housing Project Interior Photo. Archives and Special Collections, University of Louisville, D. W. Beard Public Housing Collections, 87.61.50. 


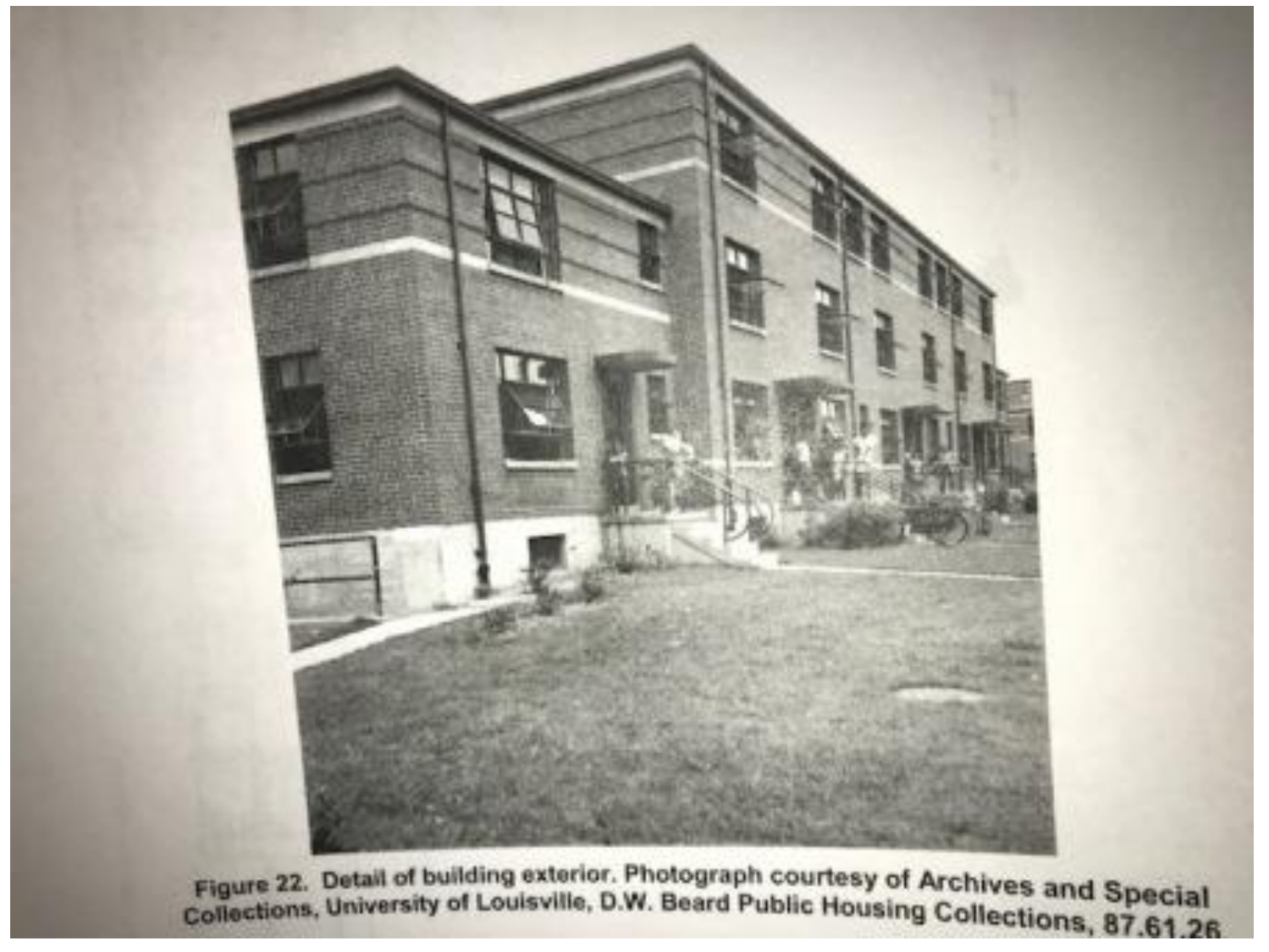

Figure 30. Beecher Terrace Exterior. Archives and Special Collections, University of Louisville, D. W. Beard Public Housing Collections, 87.61.26. 


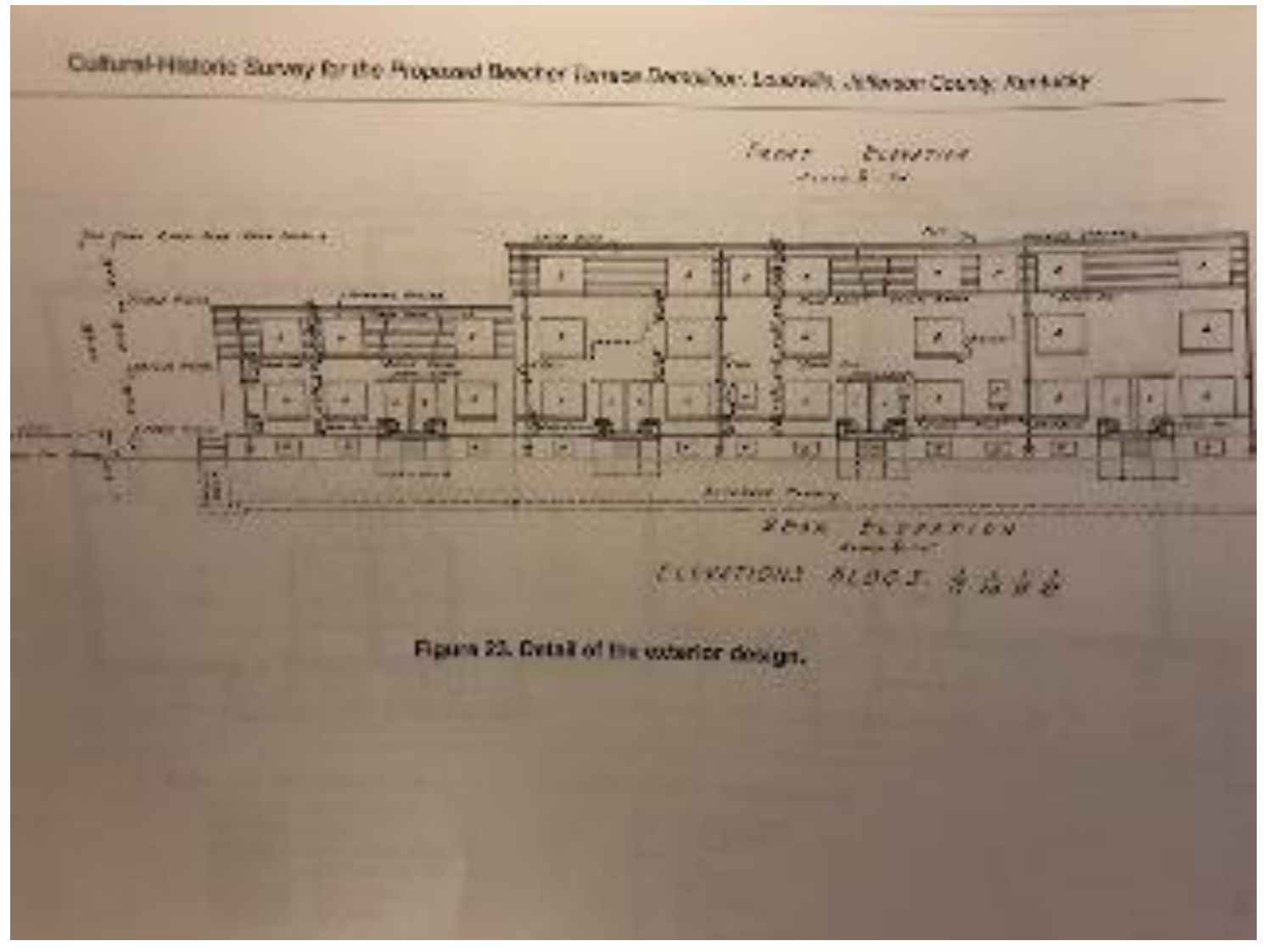

Figure 31. Beecher Terrace Elevation. No photo credit given. Published in CulturalHistoric Survey for the Proposed Beecher Terrace Demolition, Louisville, Kentucky, Jefferson County, Kentucky, p. 31. 


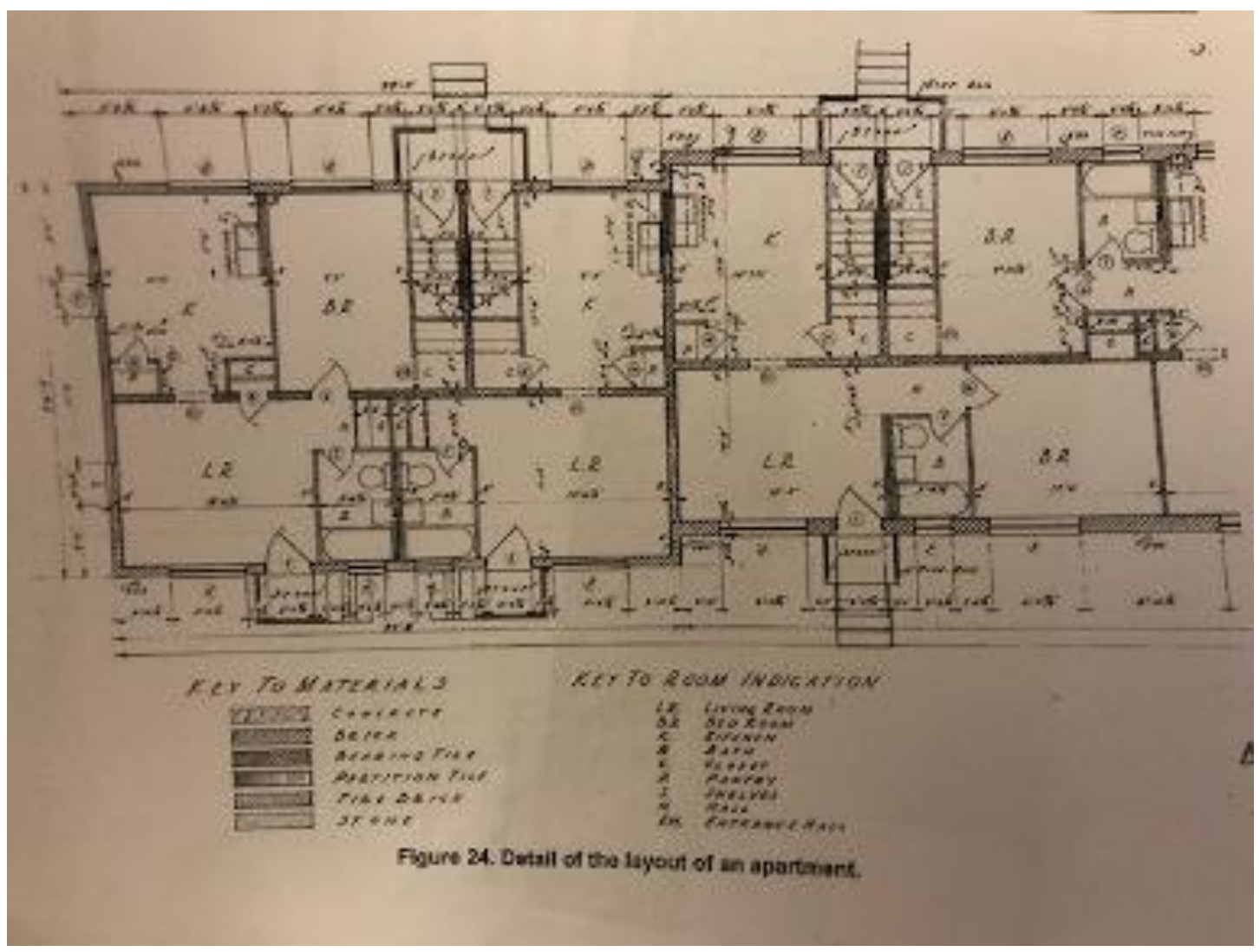

Figure 32. Beecher Terrace Floorplan. No photo credit given. Published in CulturalHistoric Survey for the Proposed Beecher Terrace Demolition, Louisville, Kentucky, Jefferson County, Kentucky, p. 32. 


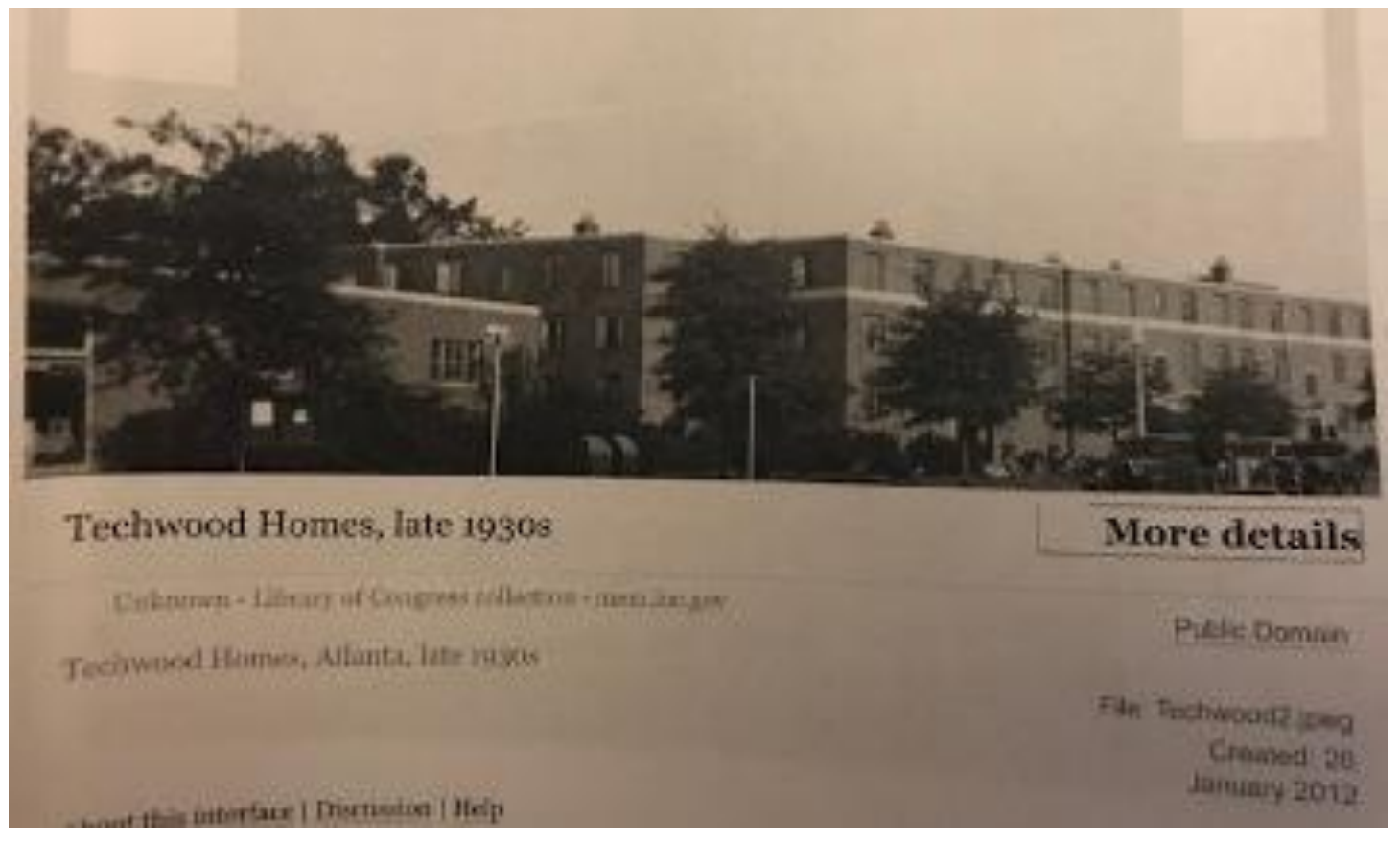

Figure 33. Techwood Homes. Unknown. Library of Congress Collection. www.mem.loc.gov. 


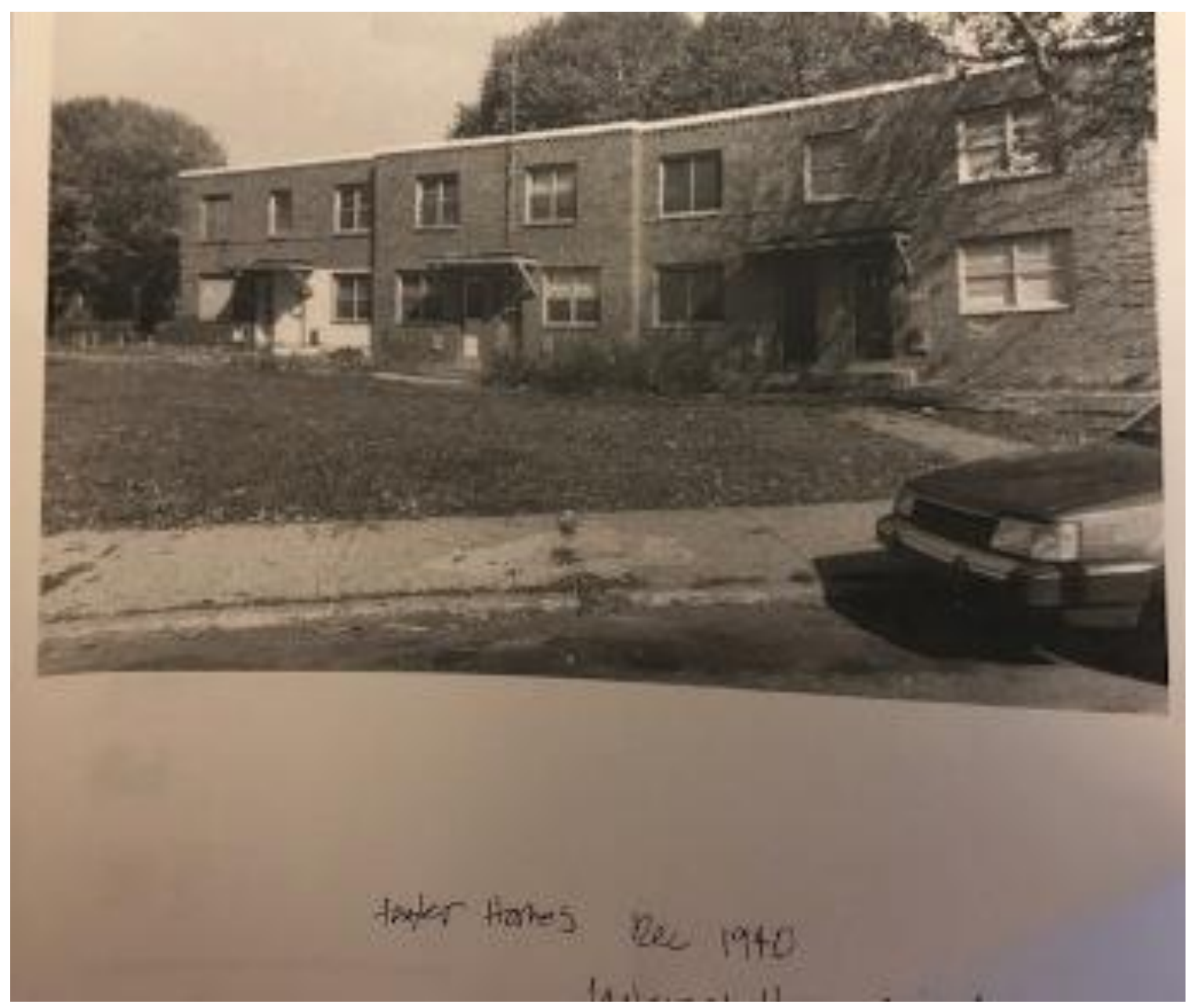

Figure 34. Tasker Homes. No photo credit given. Published in cityrooftop.files.wordpress.com/2012/07/tasker-homes.jpg. 


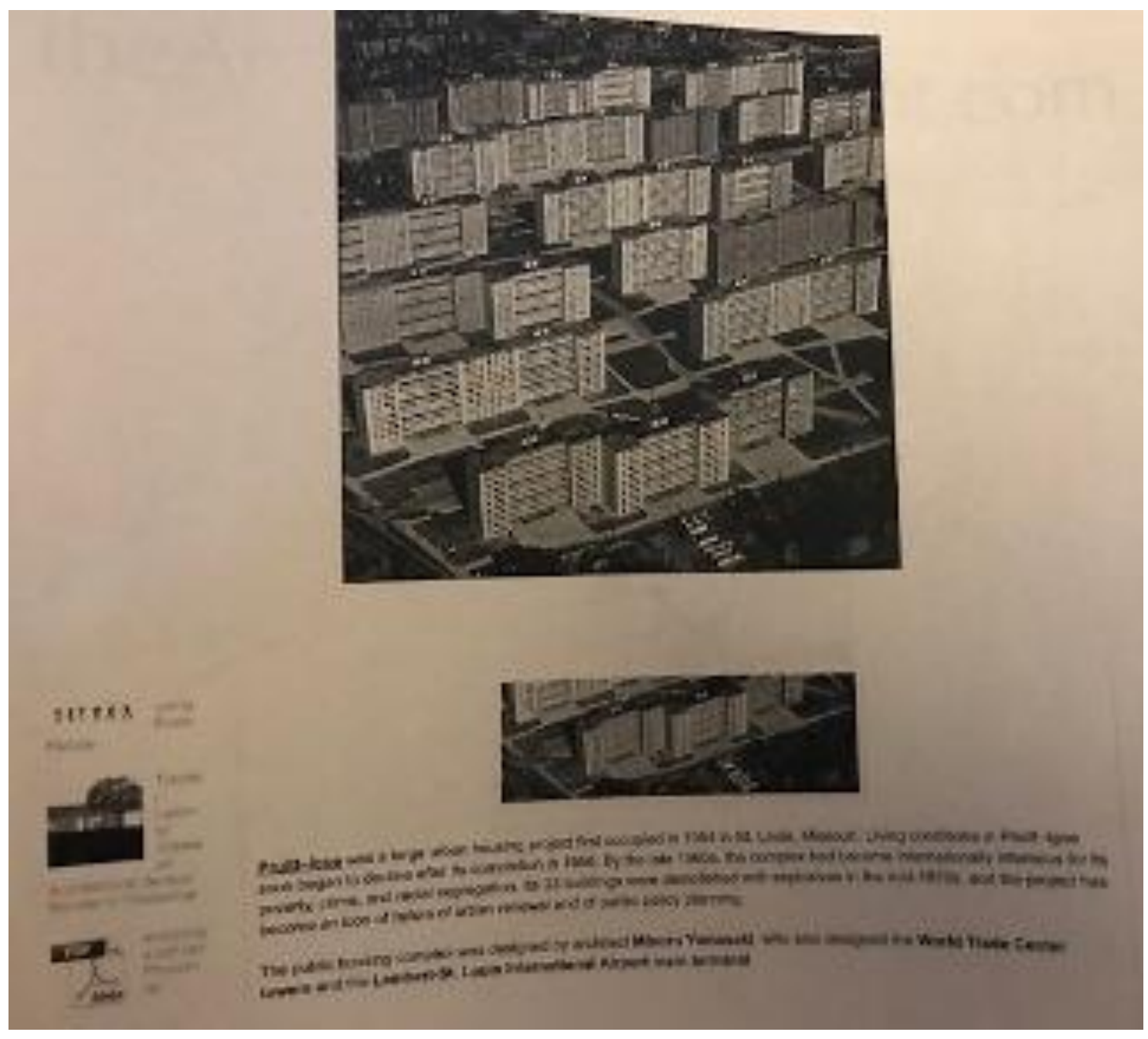

Figure 35. Pruitt-Igoe Housing Project. No photo credit given. Published in www.thearchitecturalstudent.com/2016/11/pruitt-igoe.html. 


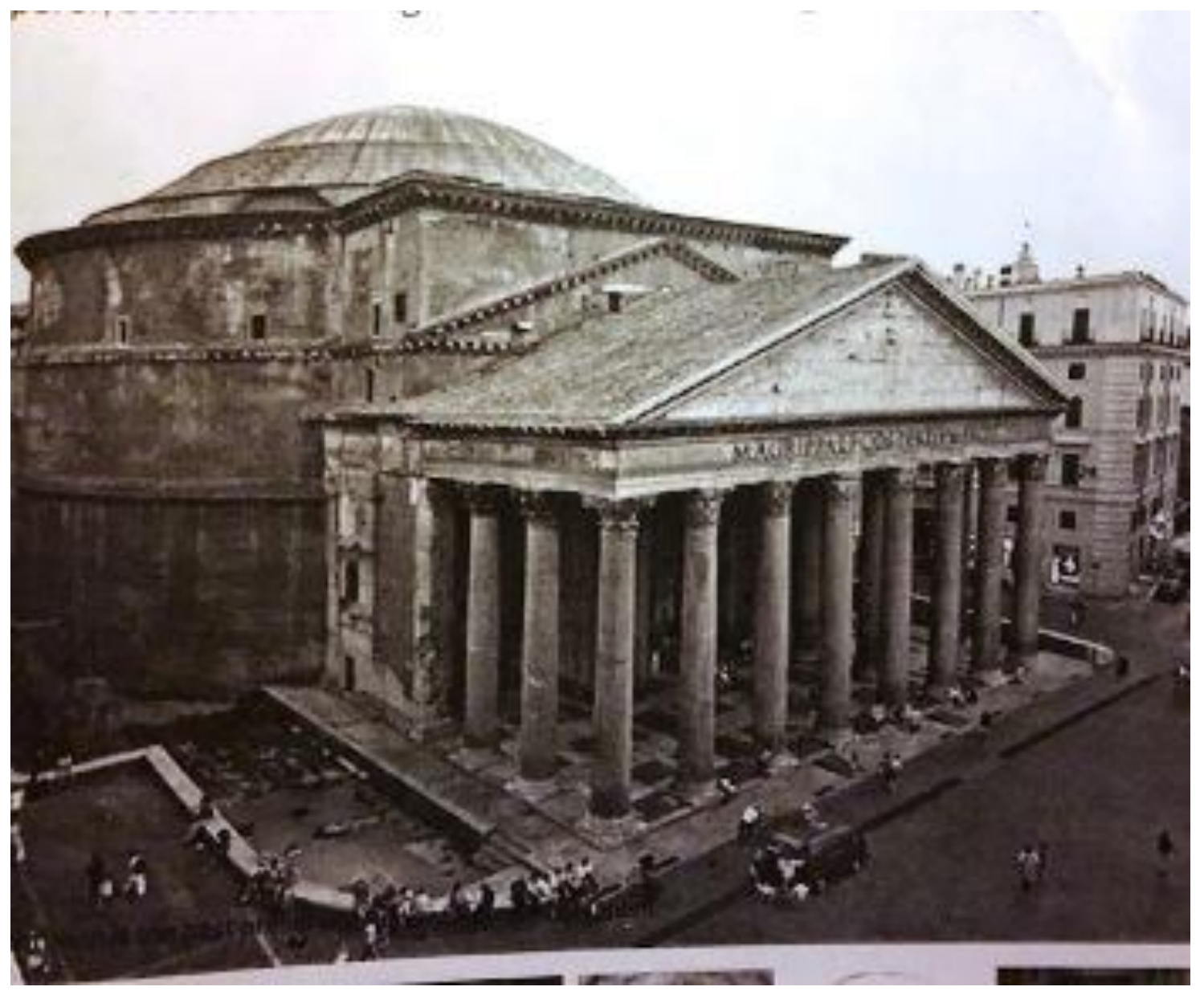

Figure 36. Pantheon. No photo credit given. Published in www.romansegway.com. 


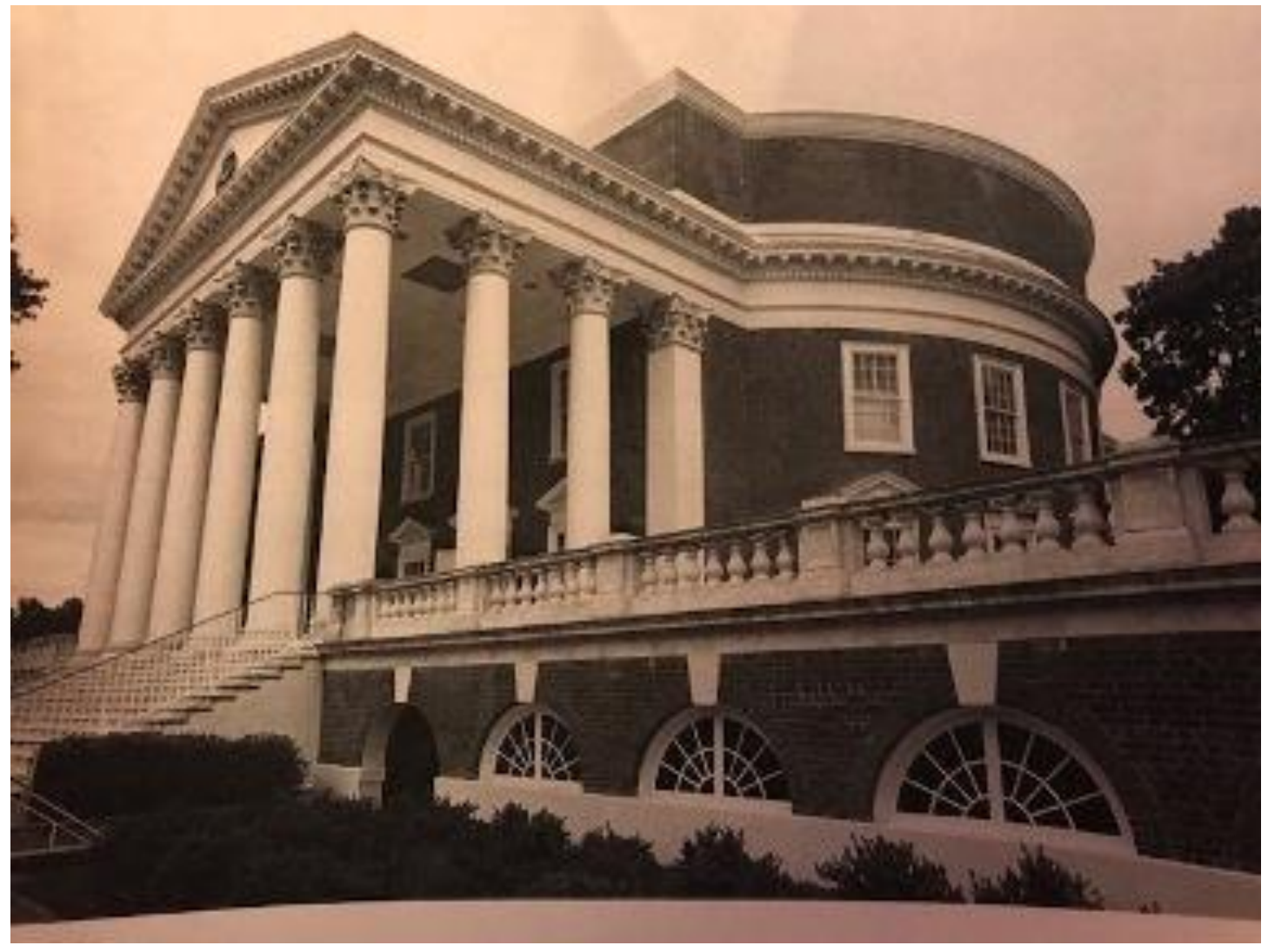

Figure 37. Rotunda, University of Virginia. No photo credit given. Published in cdn.archpaper.com/wp-content/uploads/2013/01/uva_rotunda_01.jpg. 


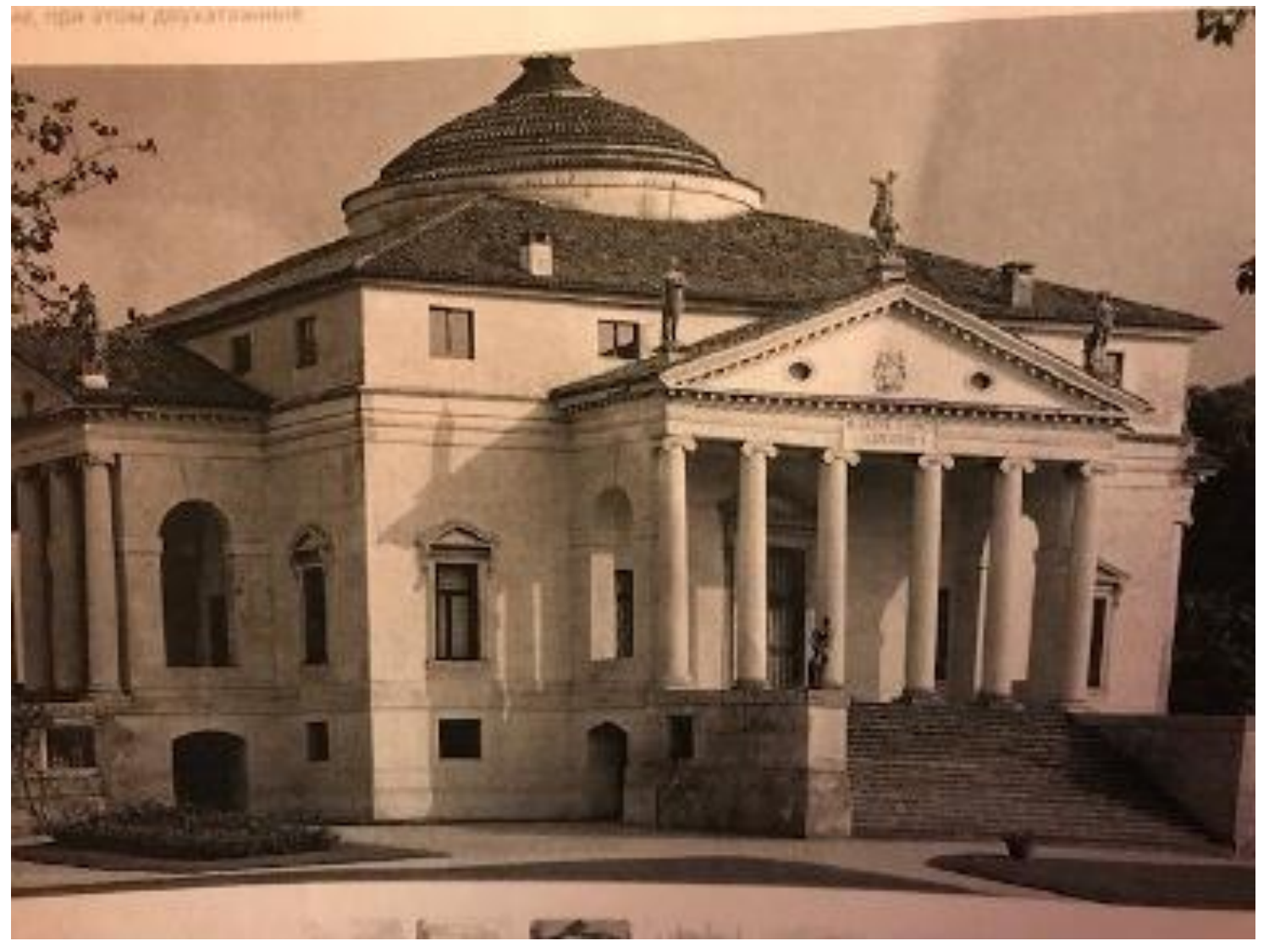

Figure 38. Villa Rotunda (Villa Capra). No photo credit given. Published in designcapital.ru/facades/img.3491. 


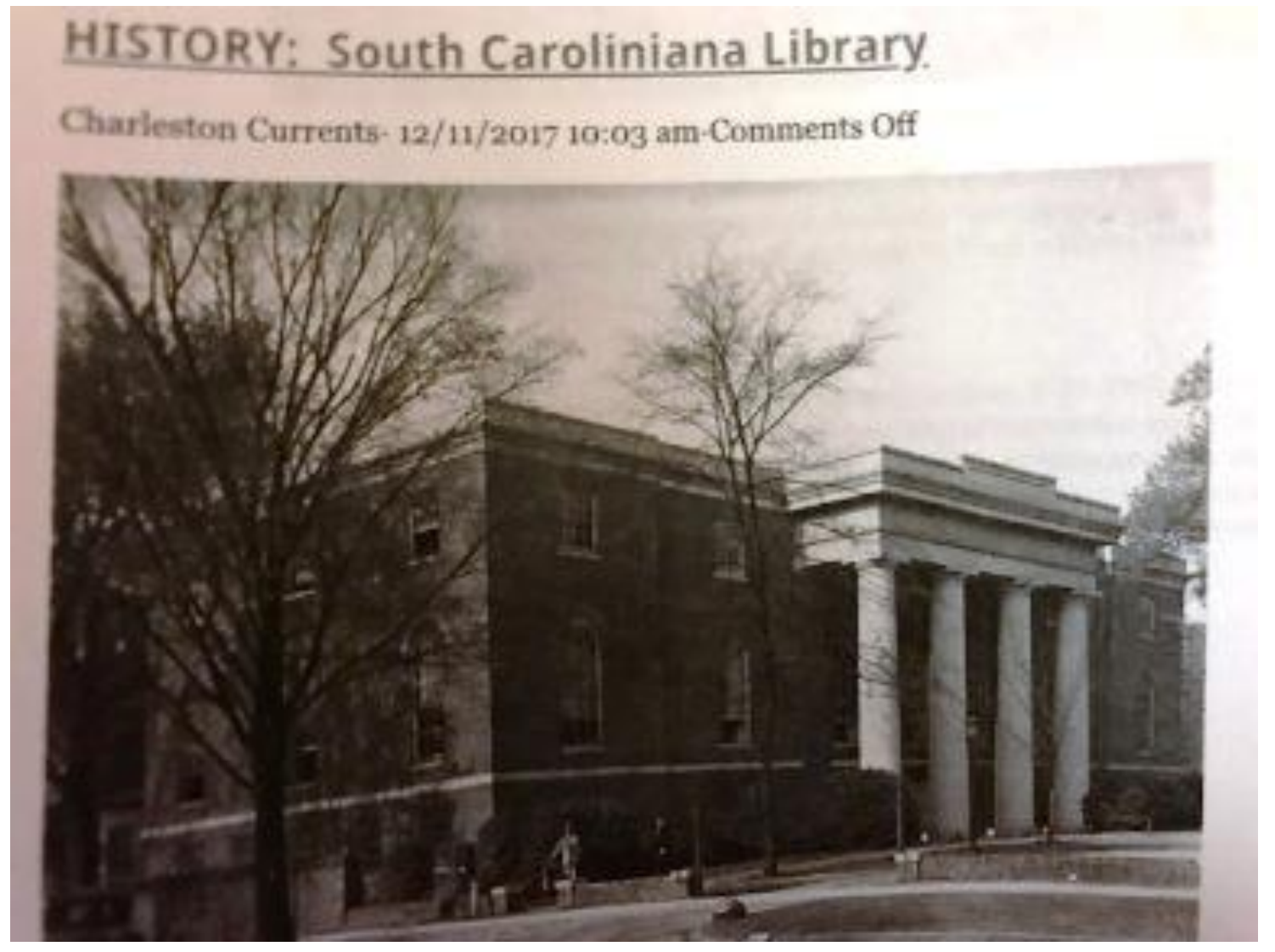

Figure 39. South Caroliniana Library. No photo credit given. Published in charlestowncurrents.com/2017/12/history-south-caroliniana-library-2/. 


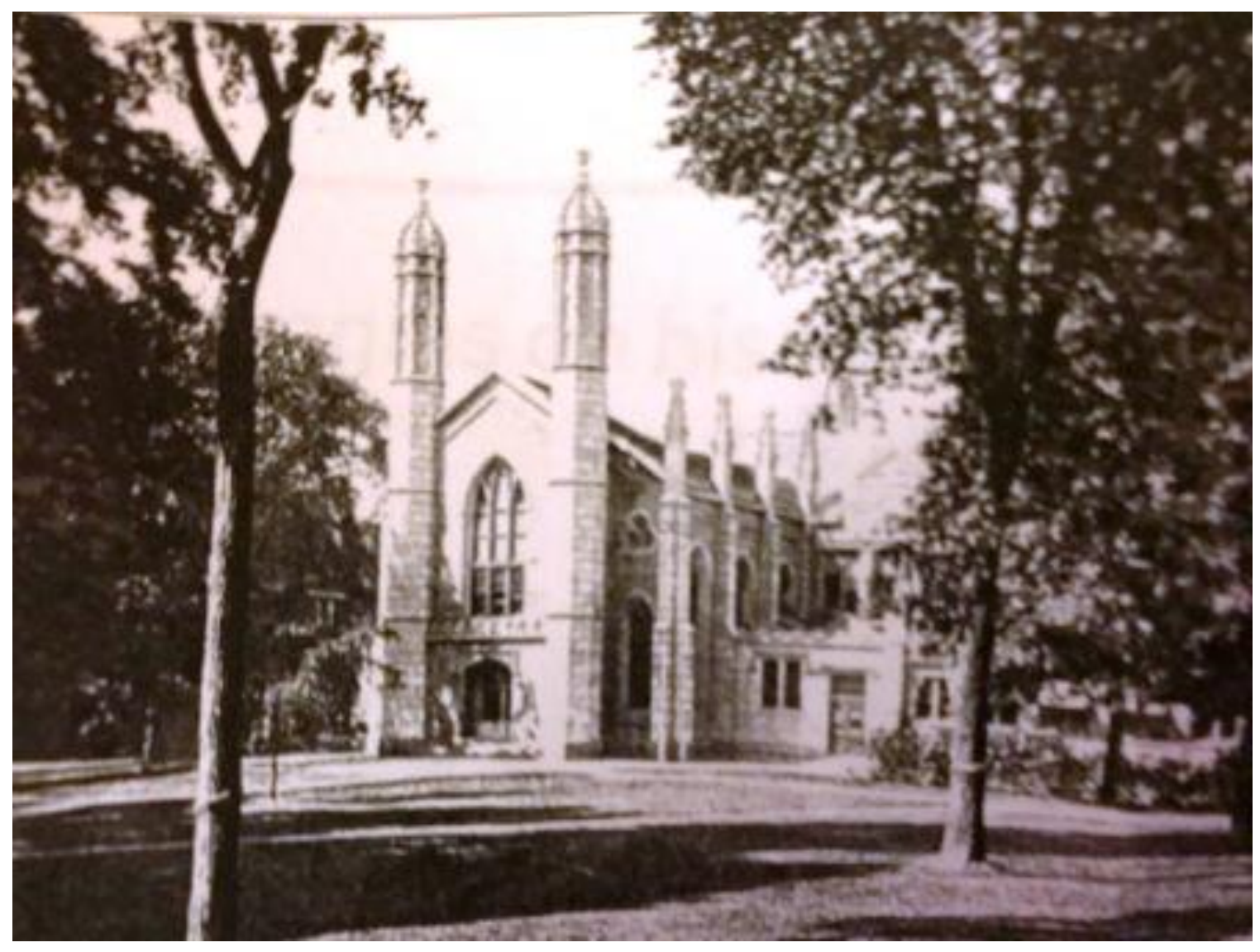

Figure 40. Gore Hall, Harvard University, early postcard view. No photo credit given. Published in roadtoparnassus.blogspot.com/2015/01/gore-hall-1838-1913a-lostharvard.html. 


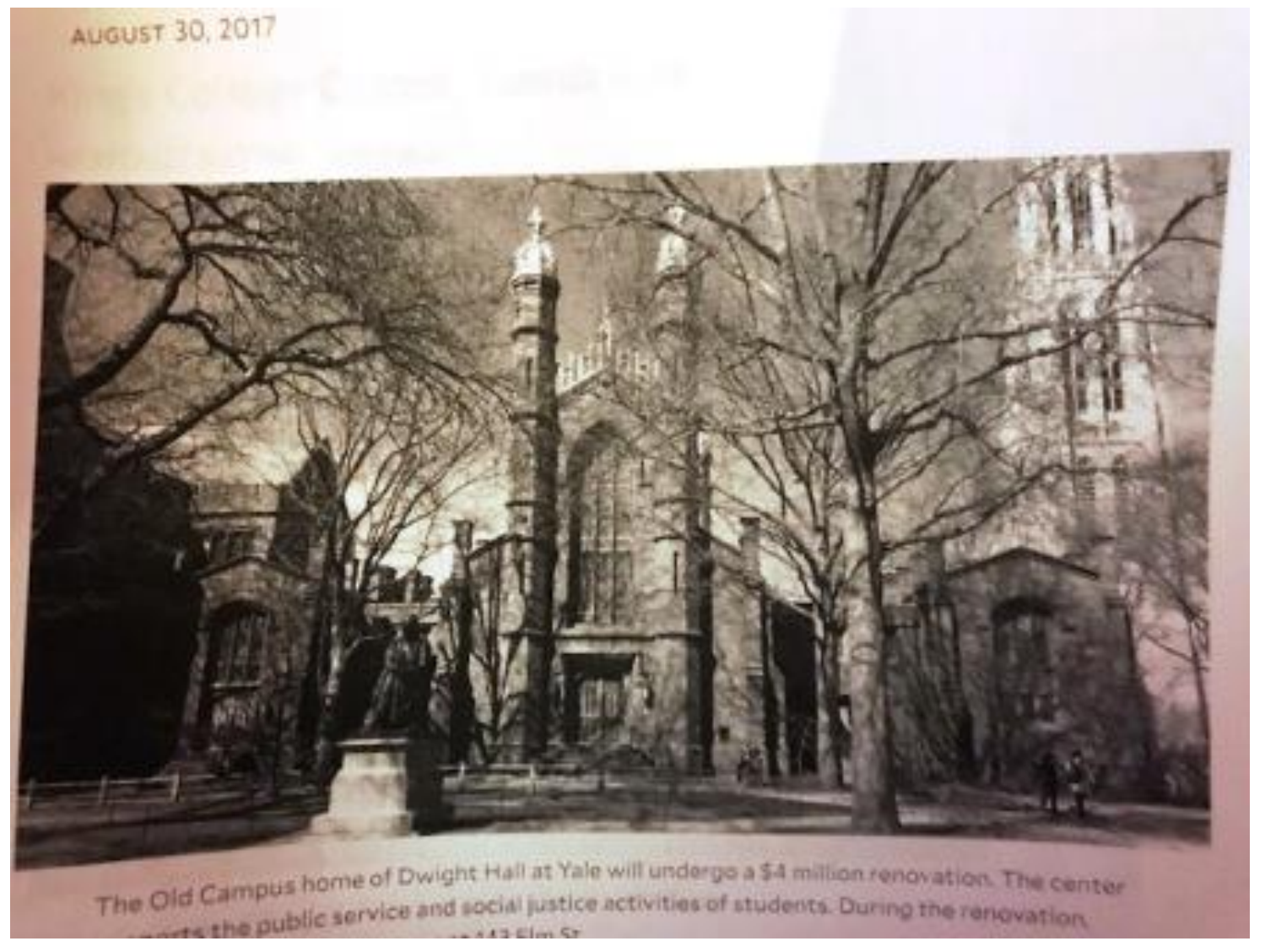

Figure 41. Dwight Hall, Yale University. No photo credit given. Published in news.yale.edu/2017/08/30/renovation-begins-historic-dwight-hall. 


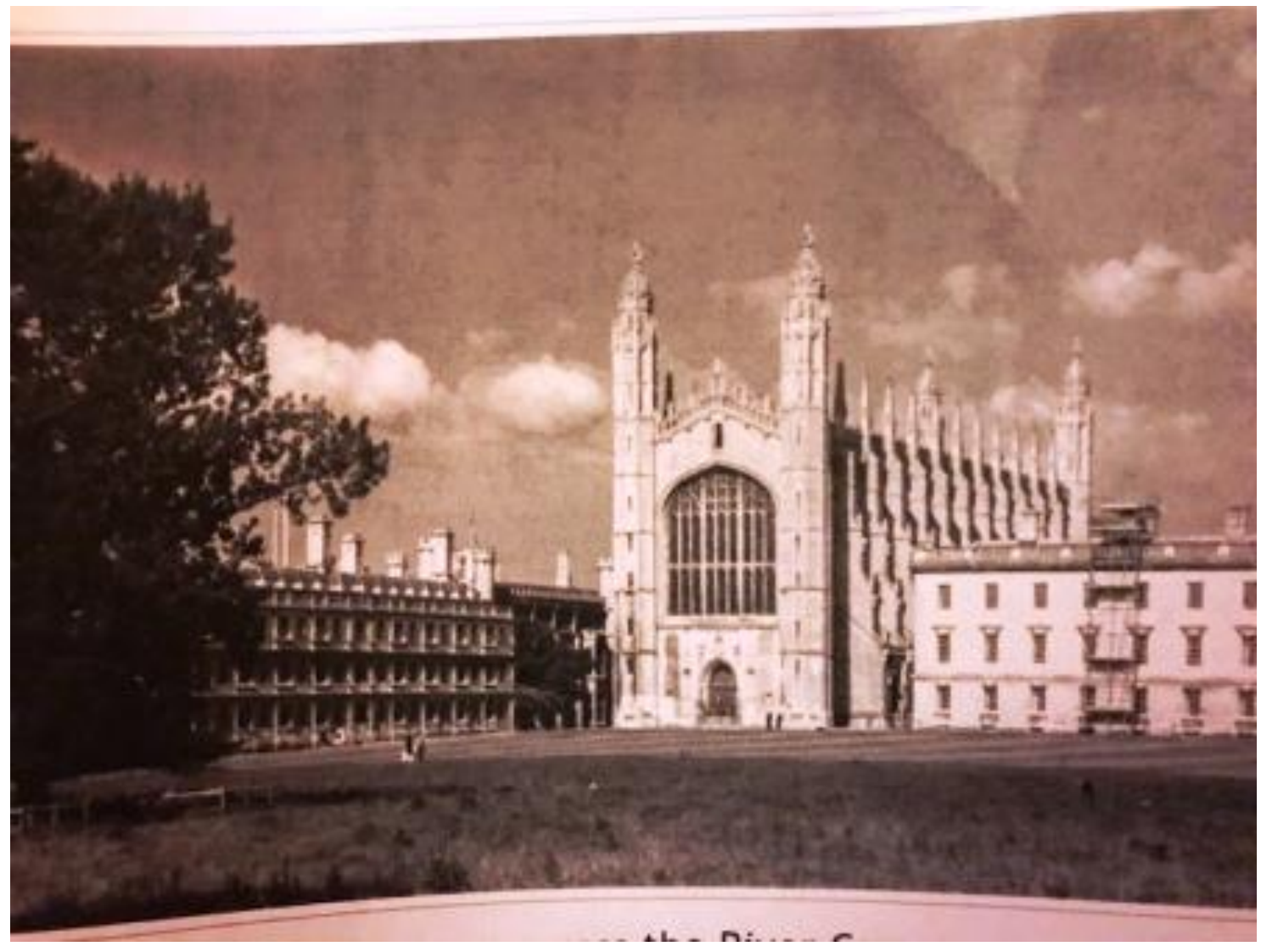

Figure 42. King's College Chapel, Cambridge University. No photo credit given.

Published in www.britainexpress.com/counties/cambridgeshire/kings-college-chapel.htm. 


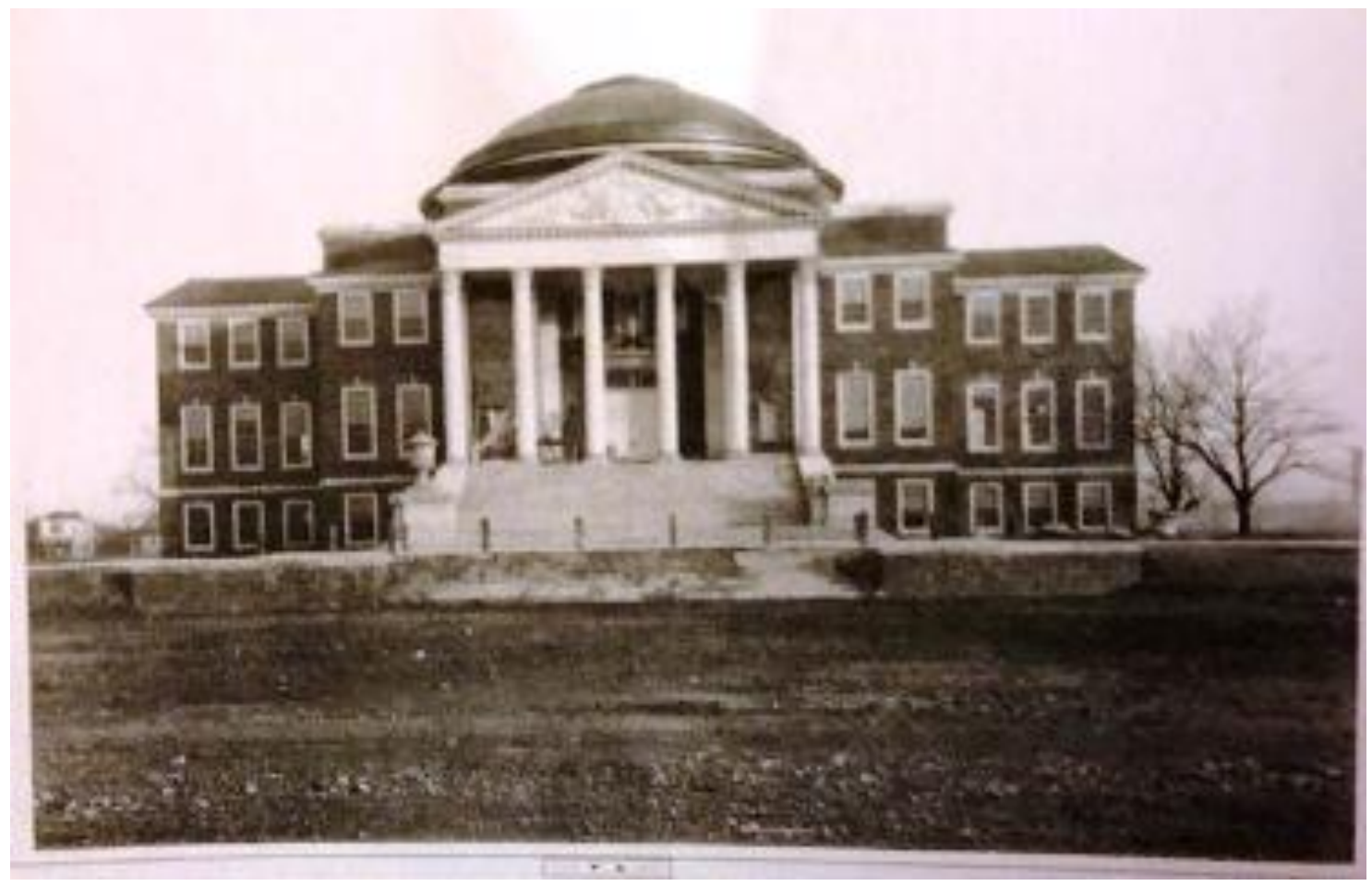

Figure 43. Administration Building, University of Louisville. Caufield \& Shook.

Published in digital.library.louisville.edu/cdm/singleitem/collections/cs/id/2199/rec/ 1351. 


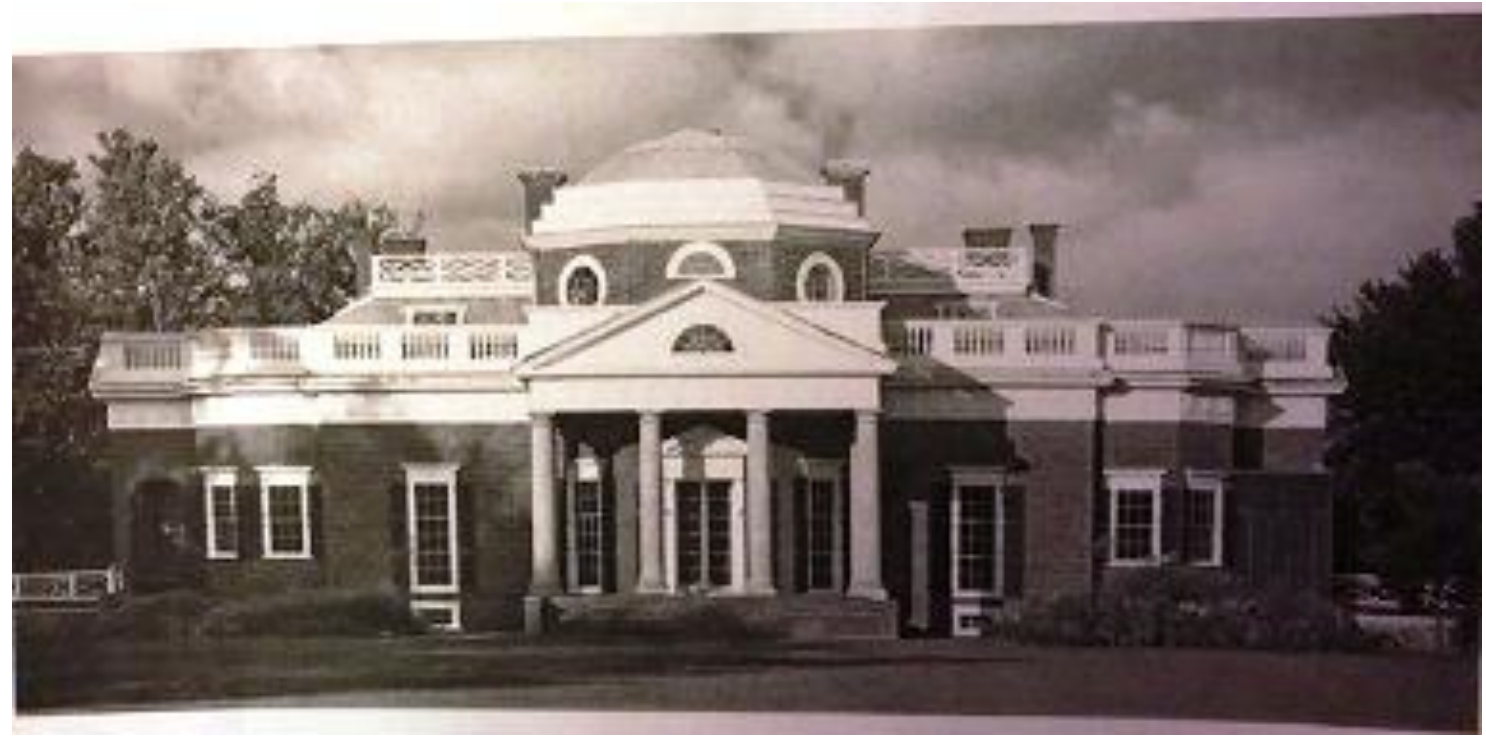

Figure 44. Monticello. No photo credit given. Published in www.monticello.org/site/press/press. 


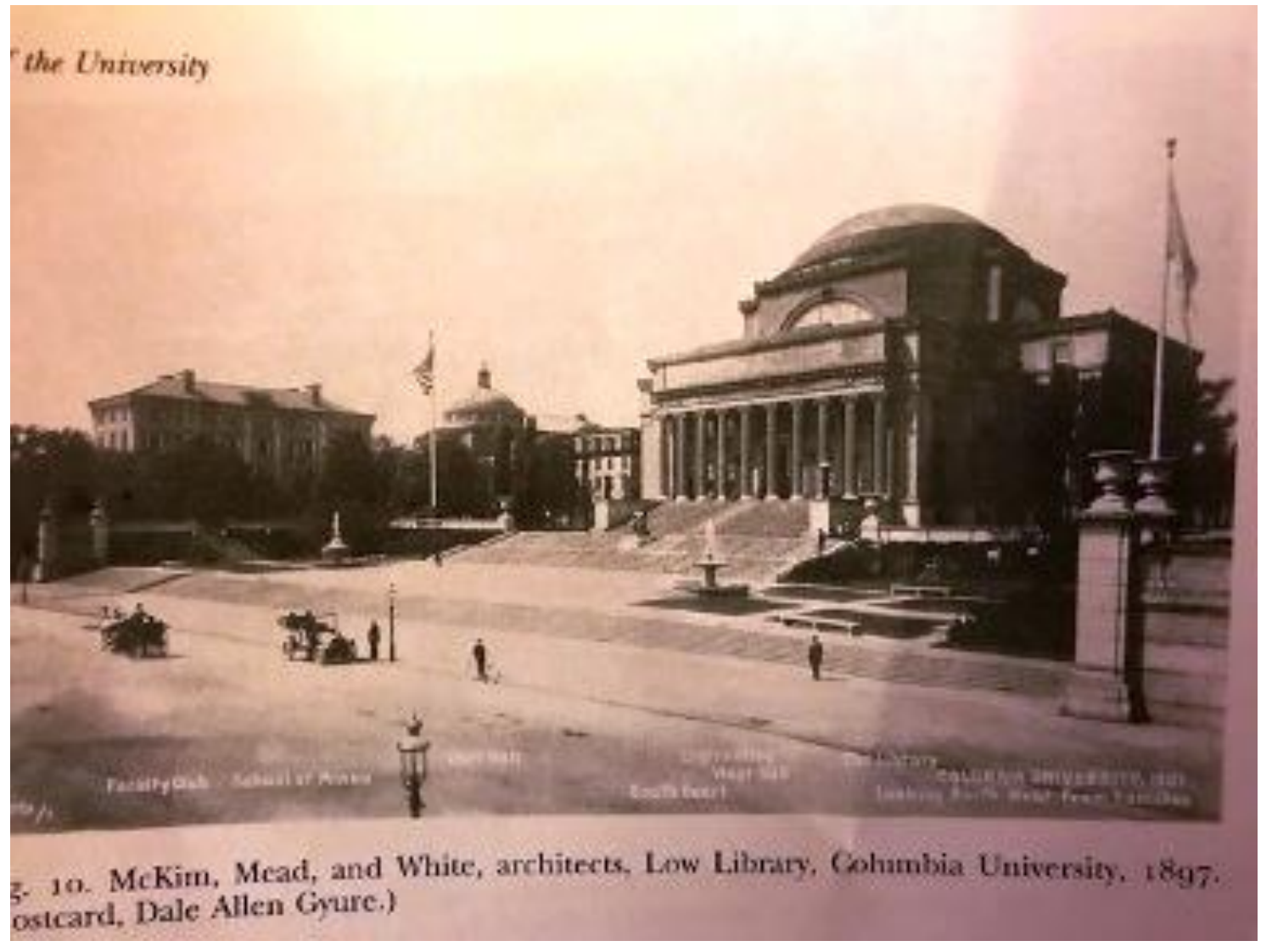

Figure 45. Law Library, Columbia University postcard, 1907. Dale Allen Gyuyre. Published in "The Heart of the University," Winterthur, vol. 4, no.2/3, 2008. 


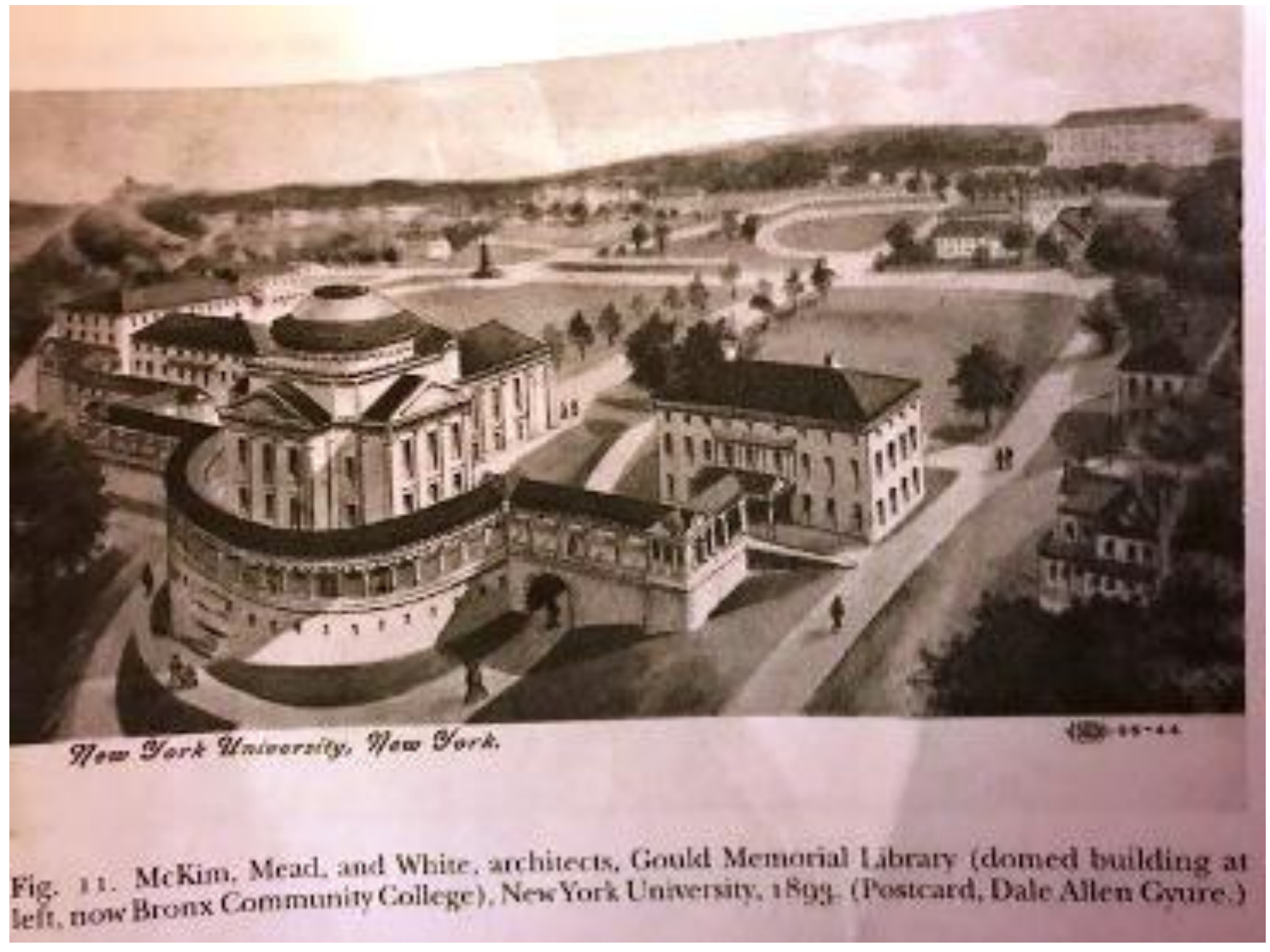

Figure 46. Gould Memorial Library postcard, 1944. Dale Allen Gyuyre. Published in

"The Heart of the University," Winterthur, vol. 4, no. 2/3, 2008. 


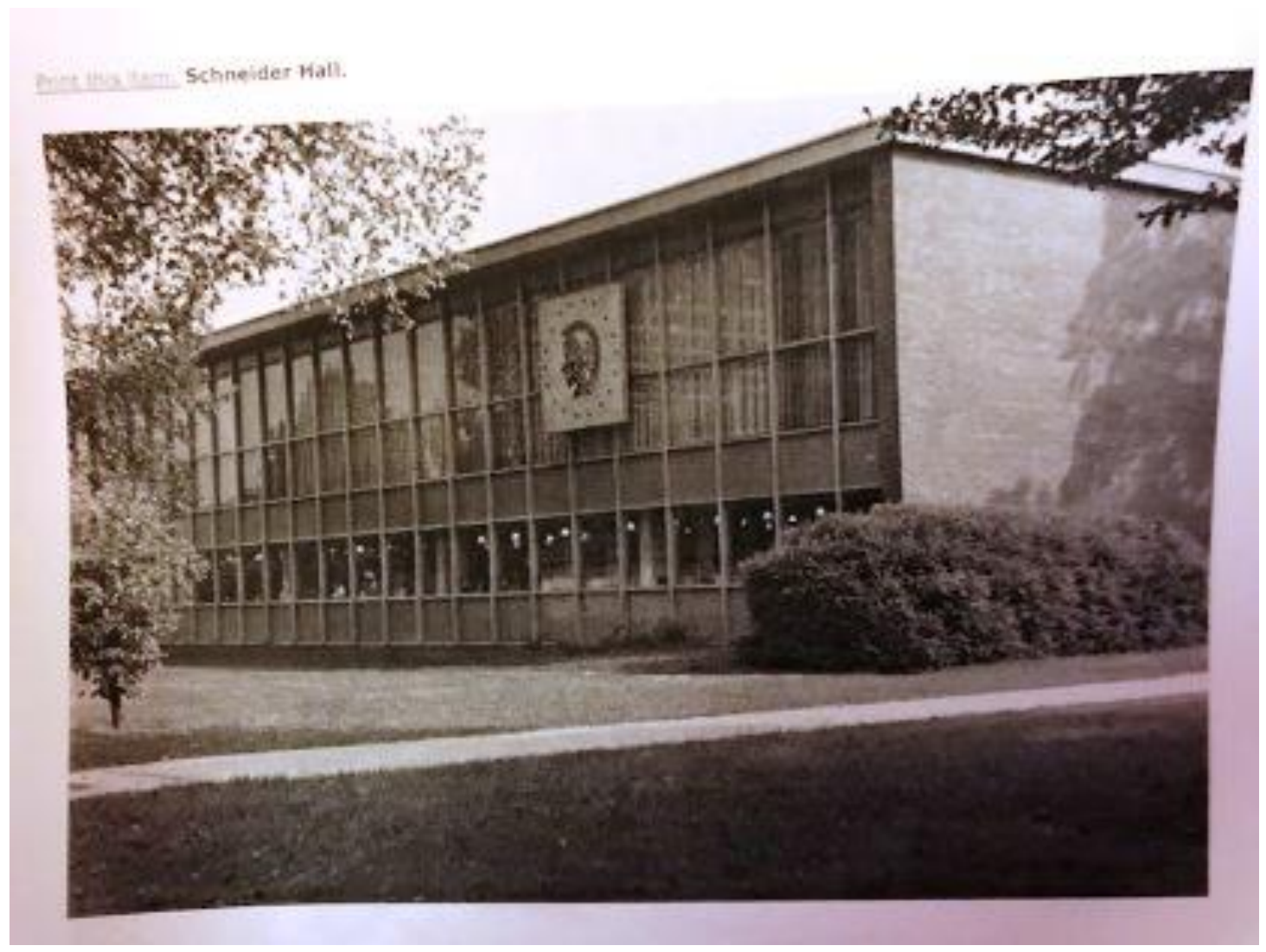

Figure 47. Schneider Hall. University of Louisville Digital Library. digital.library.louisville.edu/cdm/printview/collection/uofl/id/189/type/ singleitem. 


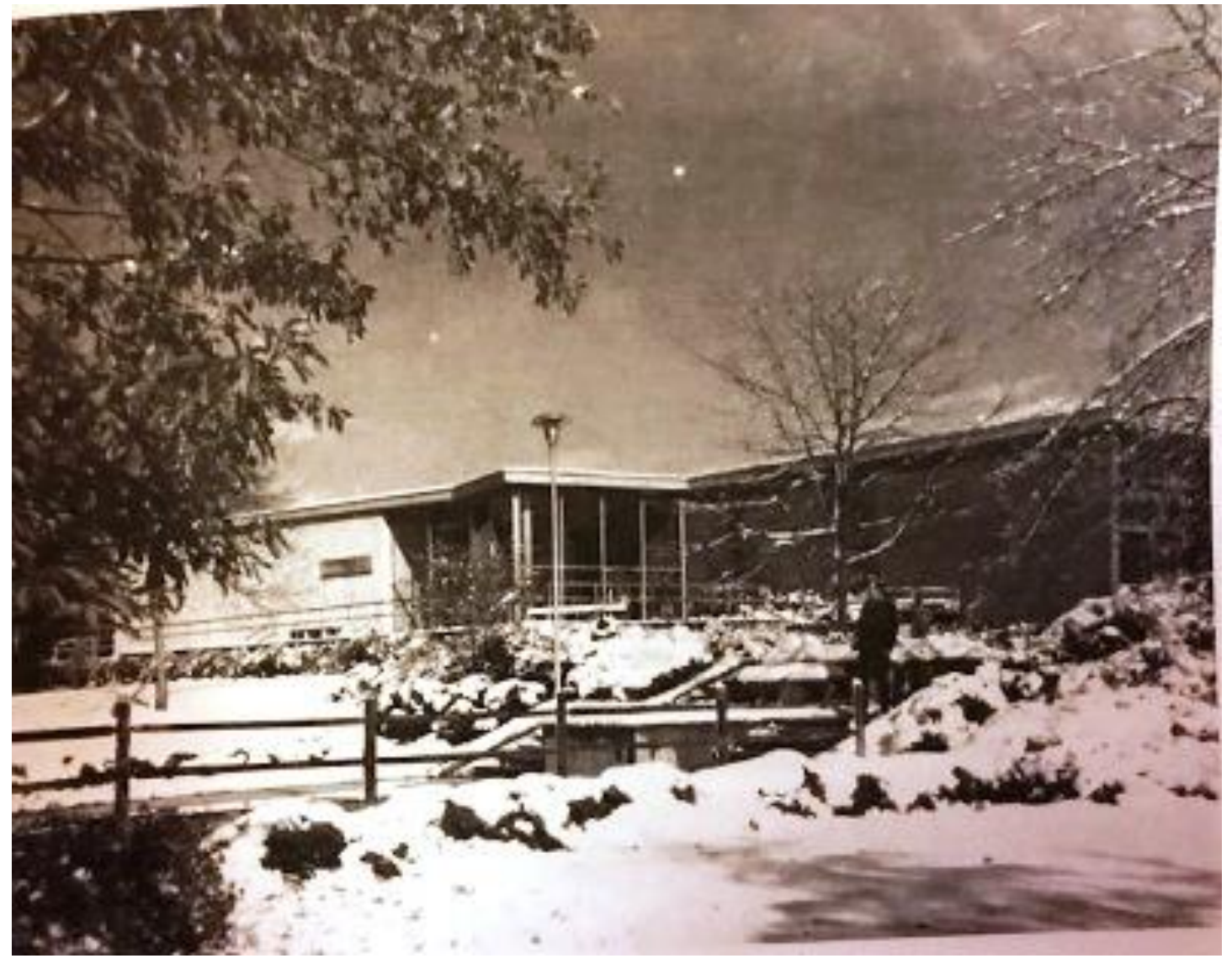

Figure 48. Schneider Hall. University of Louisville Digital Library. digital.library.louisville.edu/cdm/printview/collection/uofl/id/186/type/ singleitem. 


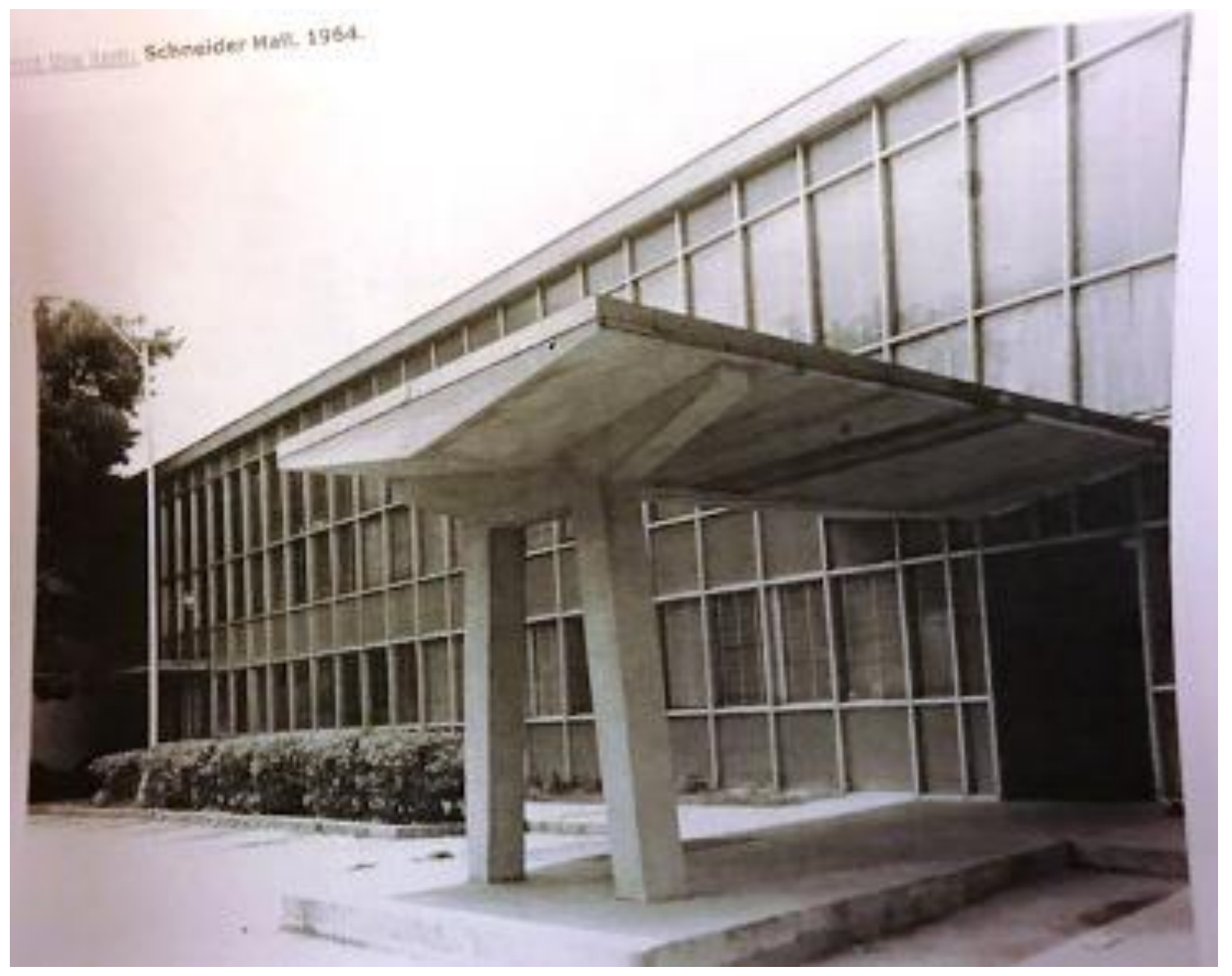

Figure 49. Schneider Hall. University of Louisville Digital Library. digital.library.louisville.edu/cdm/printview/collection/uofl/id/183/type/ singleitem. 


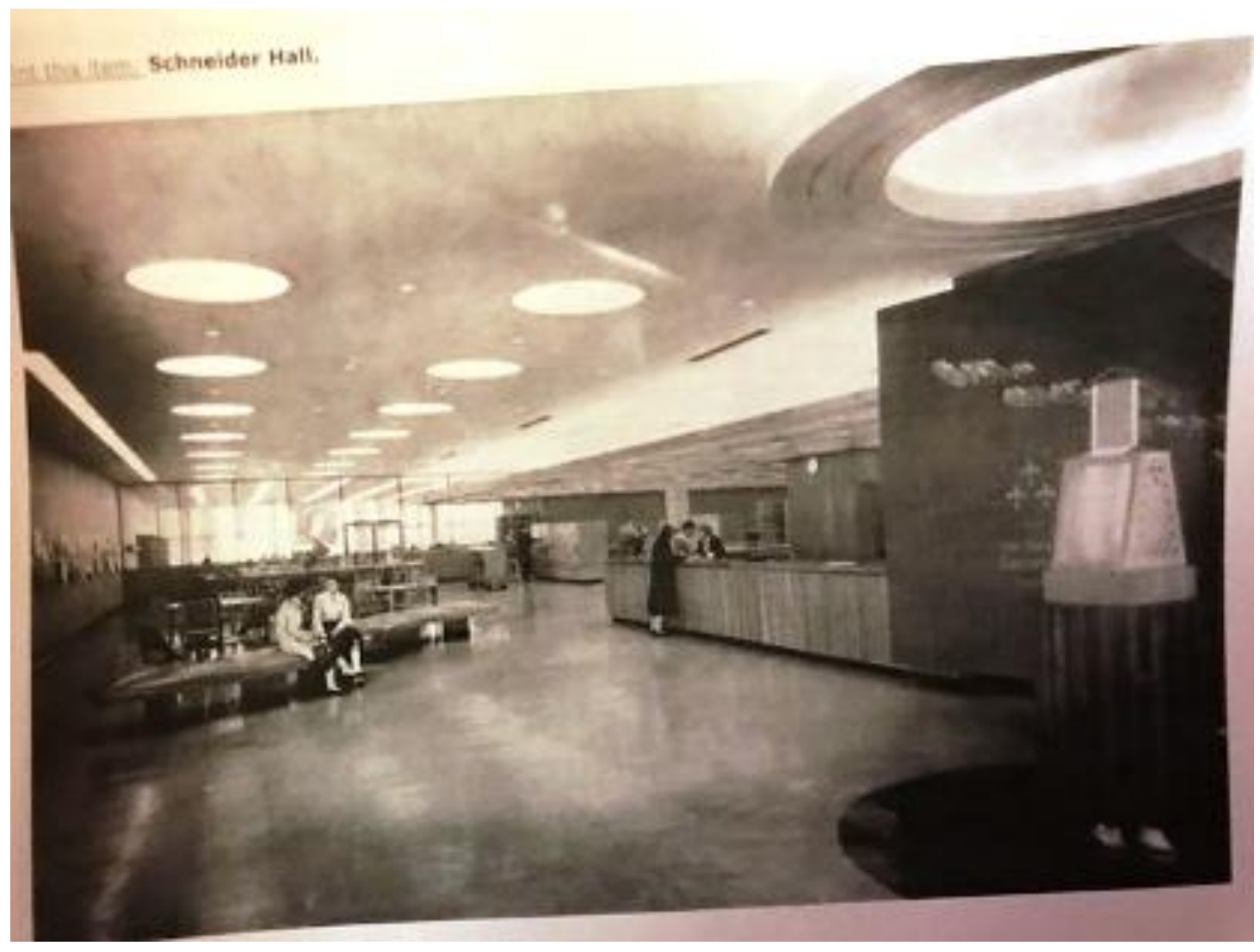

Figure 50. Schneider Hall. University of Louisville Digital Library. digiital.library.louisville.edu/cdm/printview/collection/uofl/id/185/type/ singleitem. 


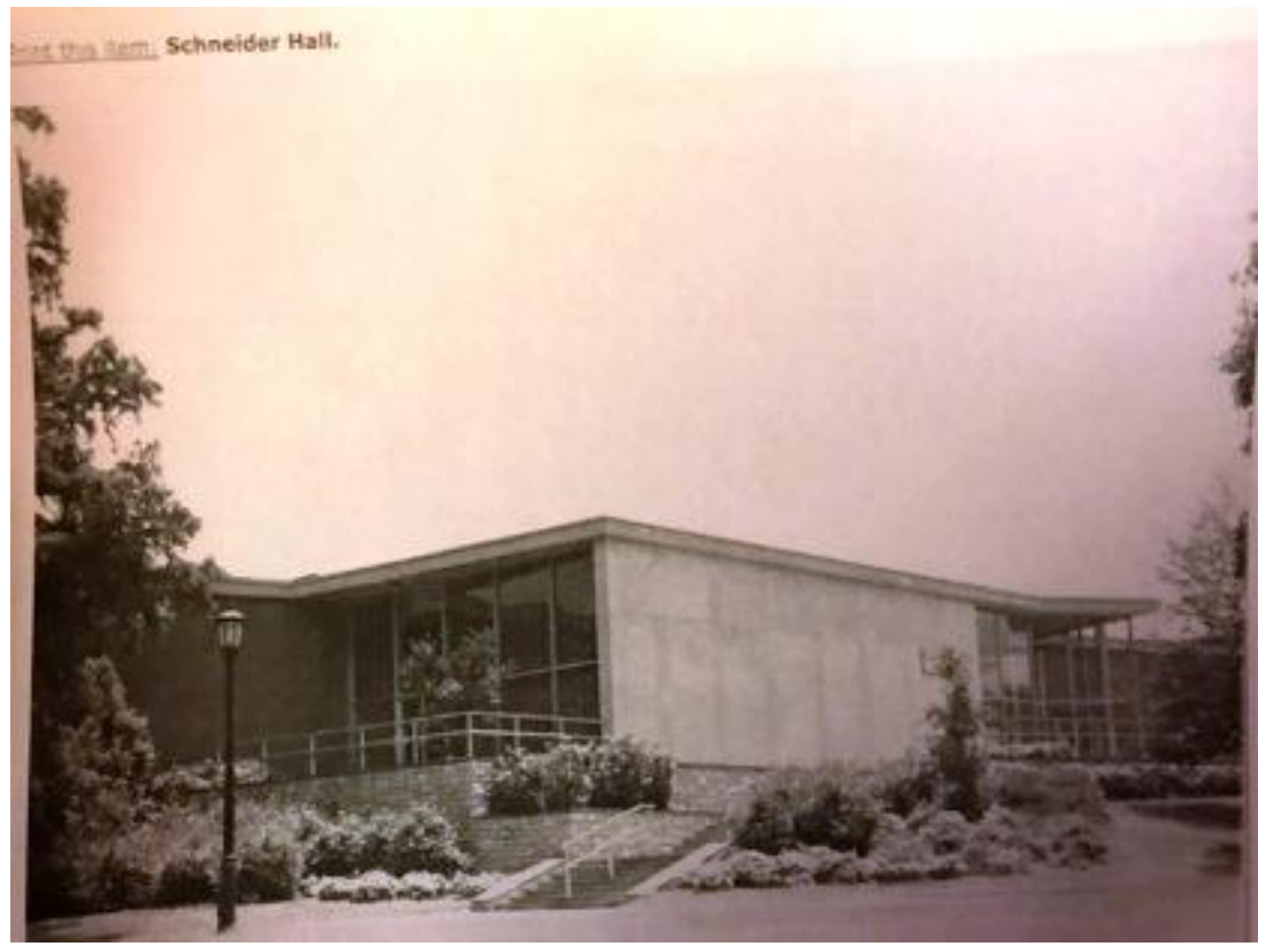

Figure 51. Schneider Hall. University of Louisville Digital Library. digital.library.louisville.edu/cdm/printview/collection/uofl/id/188/type/ singleitem. 


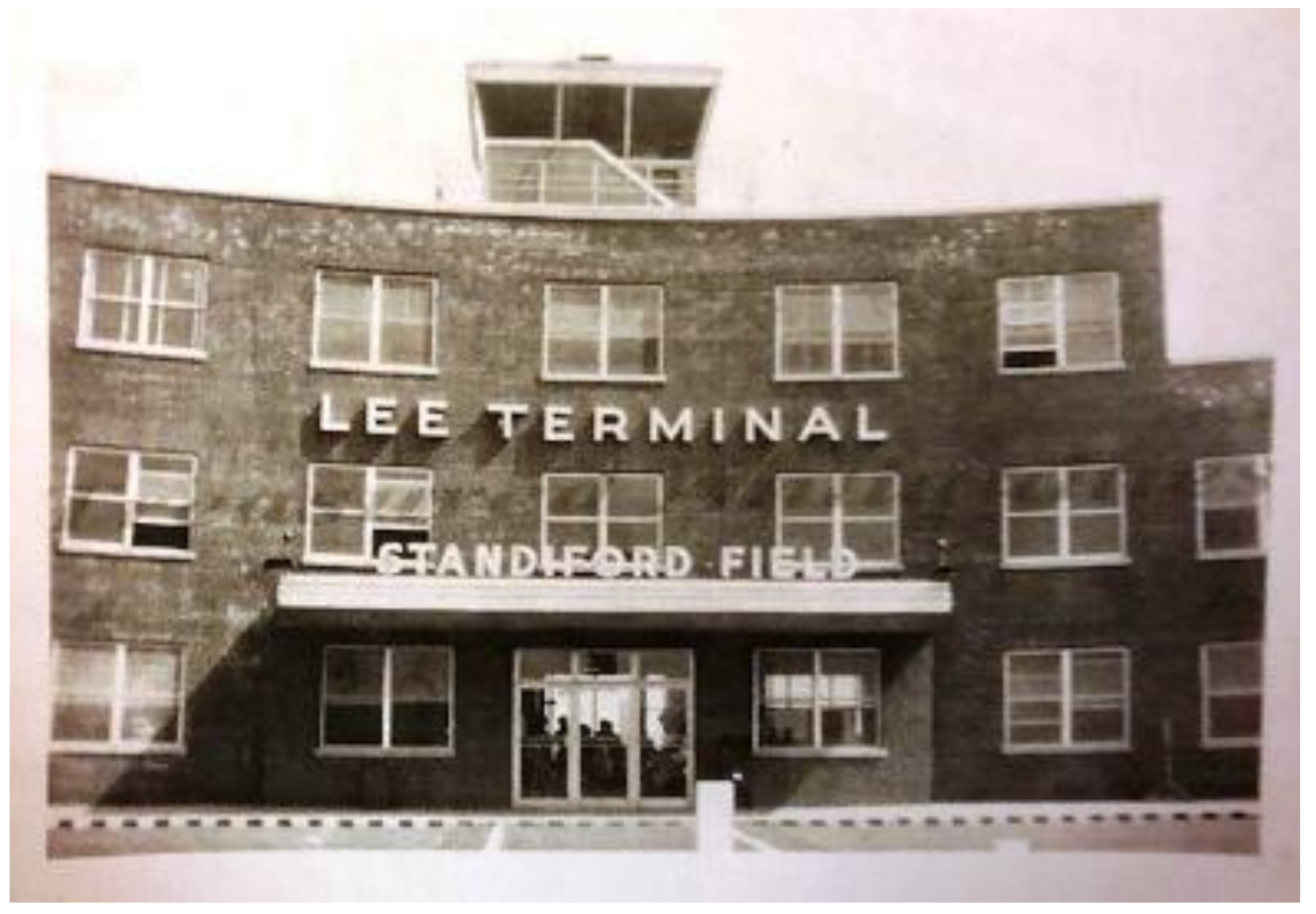

Figure 52. Lee Terminal, Standiford Field. No photo credit given. www.ebay.com/1950-Louisville-Kentucky-Airport-Standiford-Field-LeeTerminal-Tower-Photo-/311727164679. 


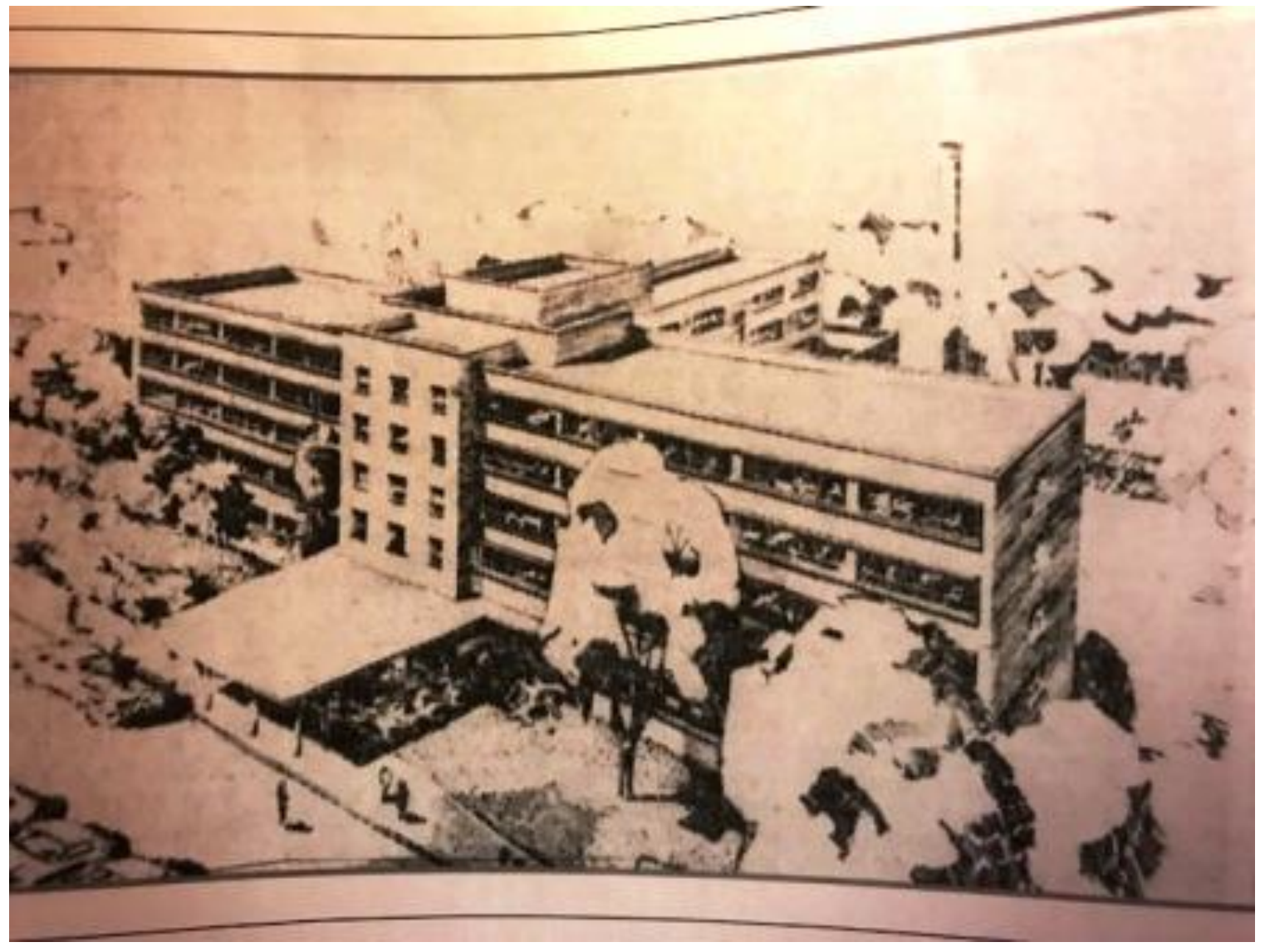

Figure 53. Methodist Episcopal Hospital. No photo credit given. The Courier-Journal, Thursday, September 6, 1956. www.newspapers.com. 


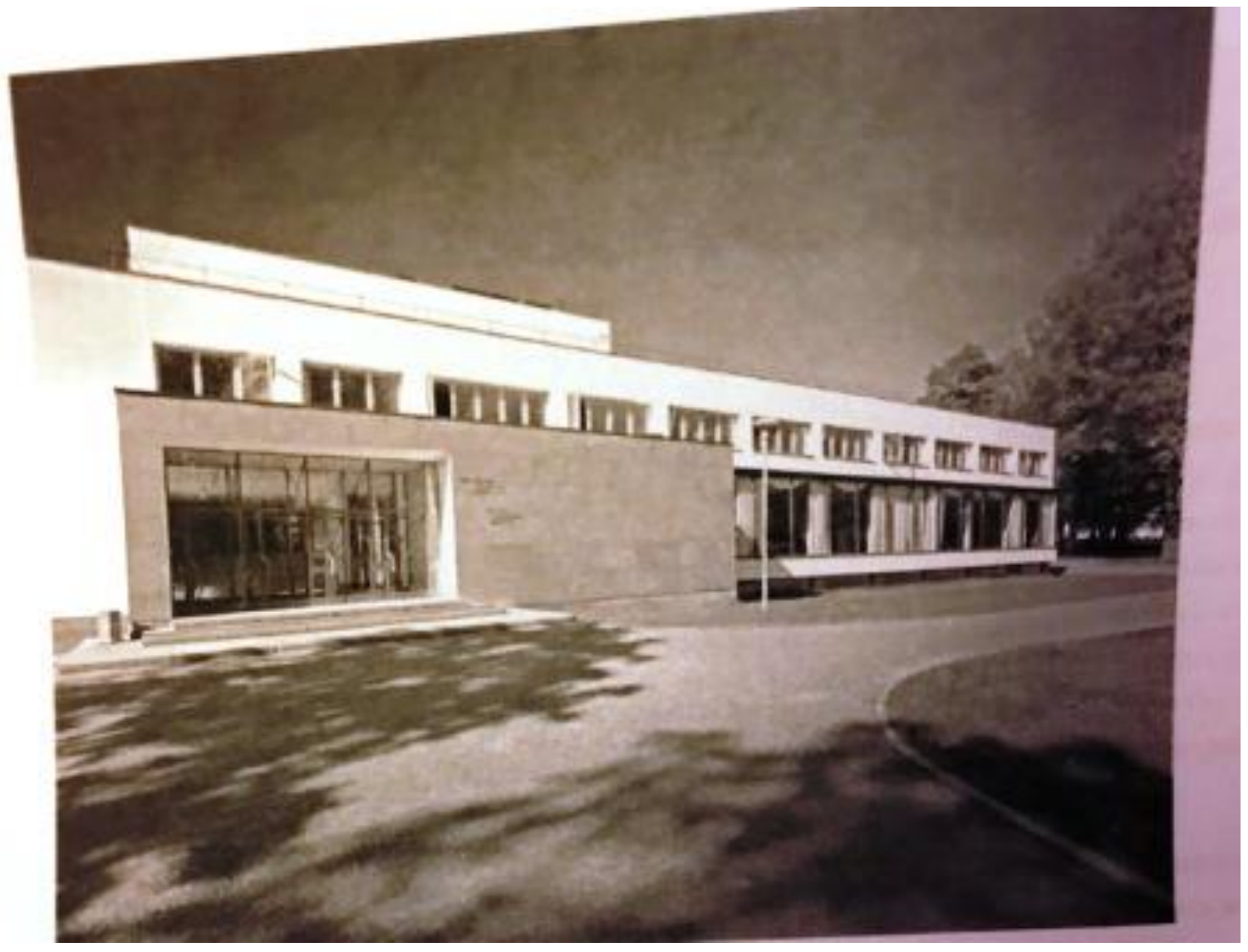

Figure 54. Viipuri Library. No photo credit given. www.wmf.org/project/viipurilibrary. 


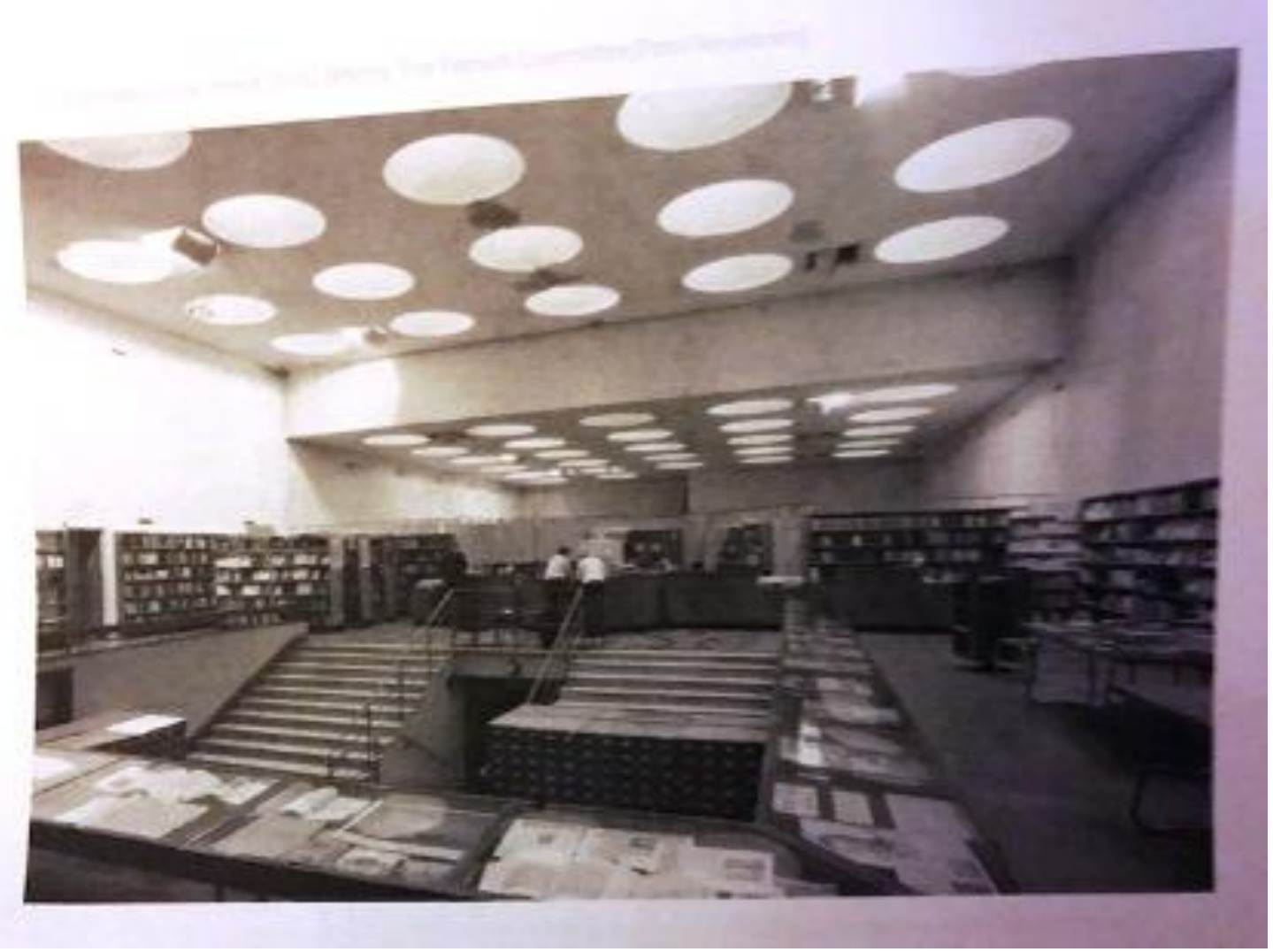

Figure 55. Viipuri Library. No photo credit given. www.wmf.org/project/viipurilibrary. 


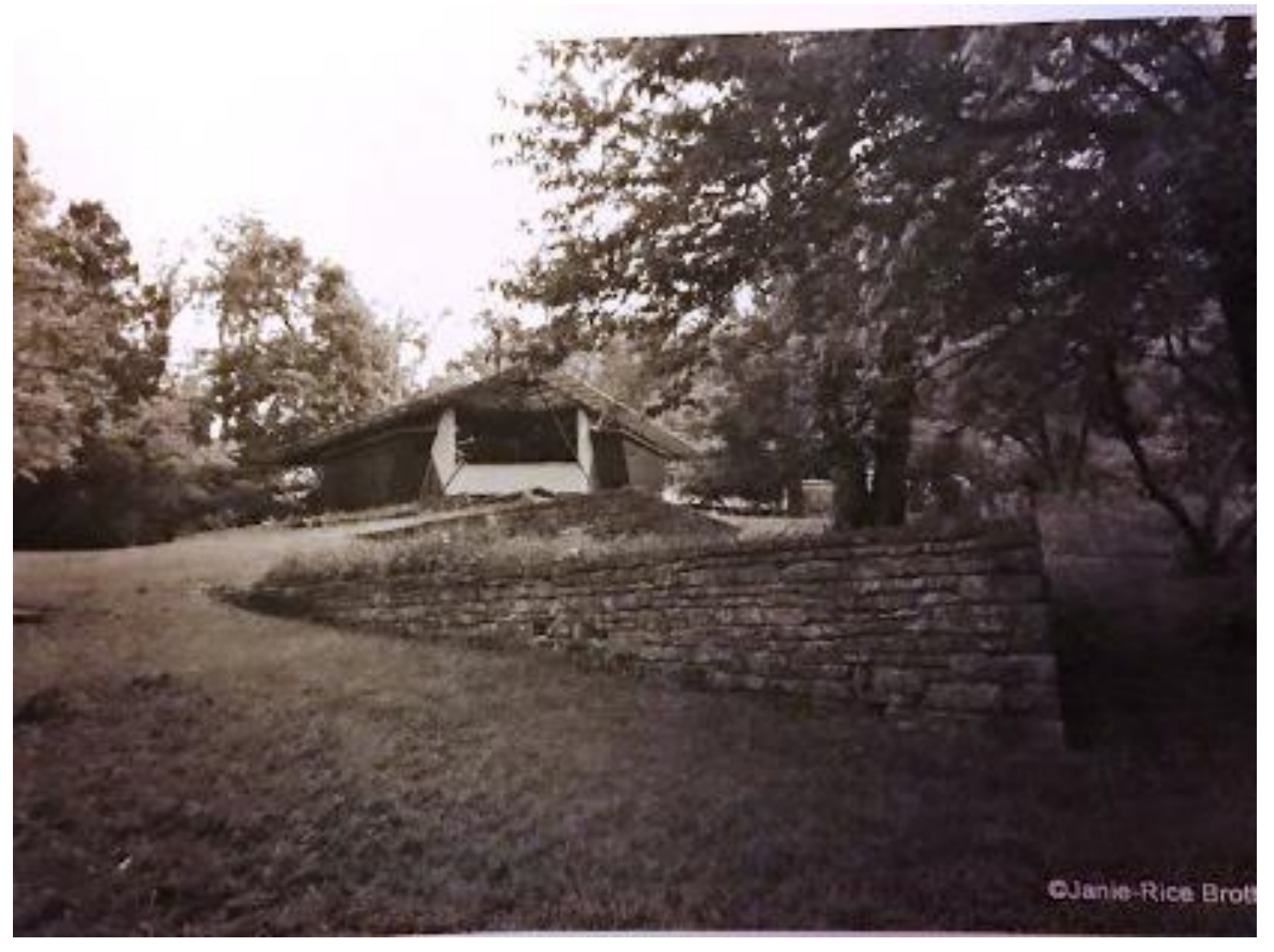

Figure 56. Modern House (Triaero House). Janie-Rice Brother.

i2.wp.com/www.gardenstogables.com/wp-content/uploads/2015/05/DSC_0437.jpg. 


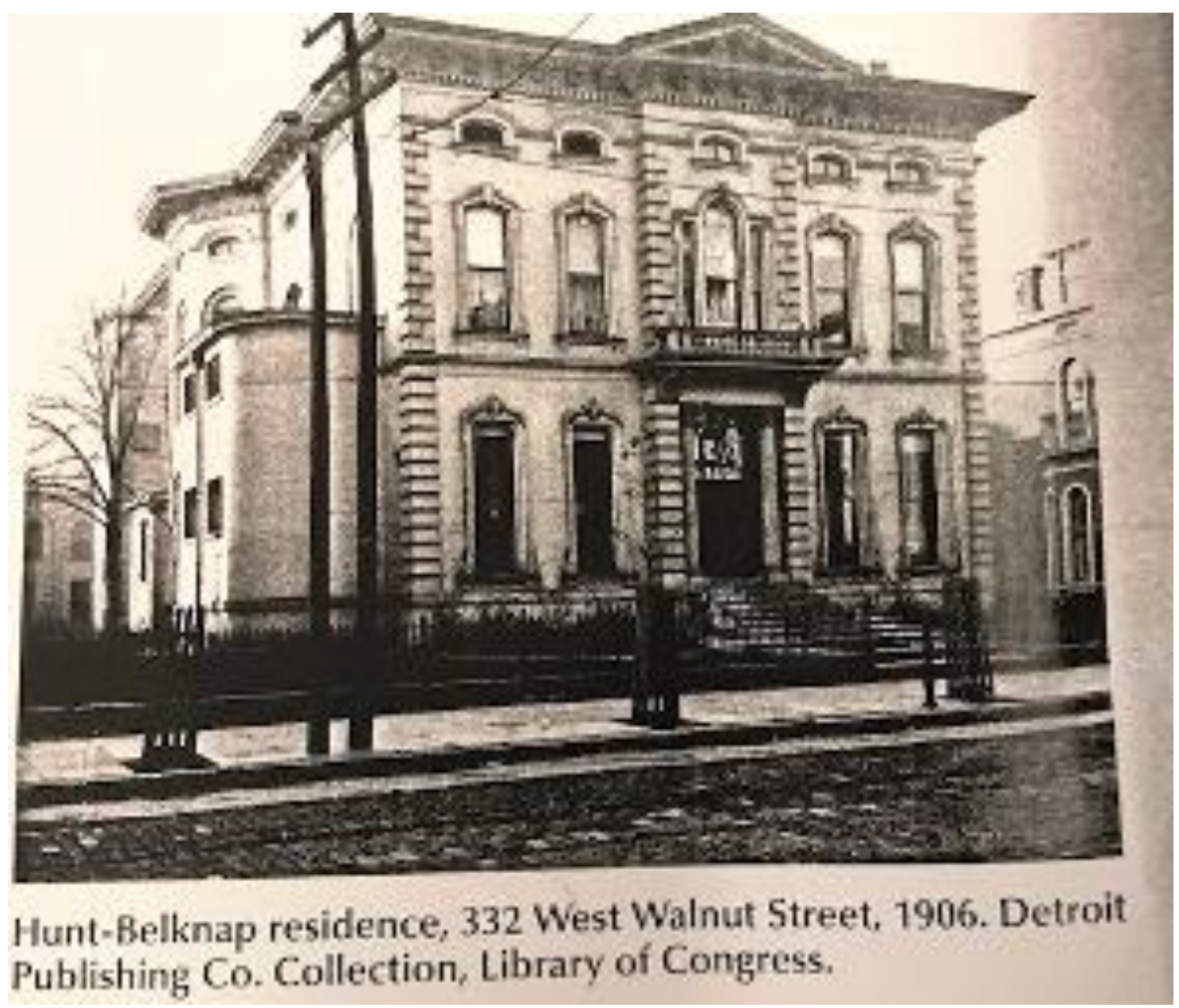

Figure 57. Hunt-Belknap Residence. Detroit Publishing Co. Collection, Library of Congress. The Architecture of Louisville 1778-1900. Louisville, George Rogers Clark Press, 2009. 


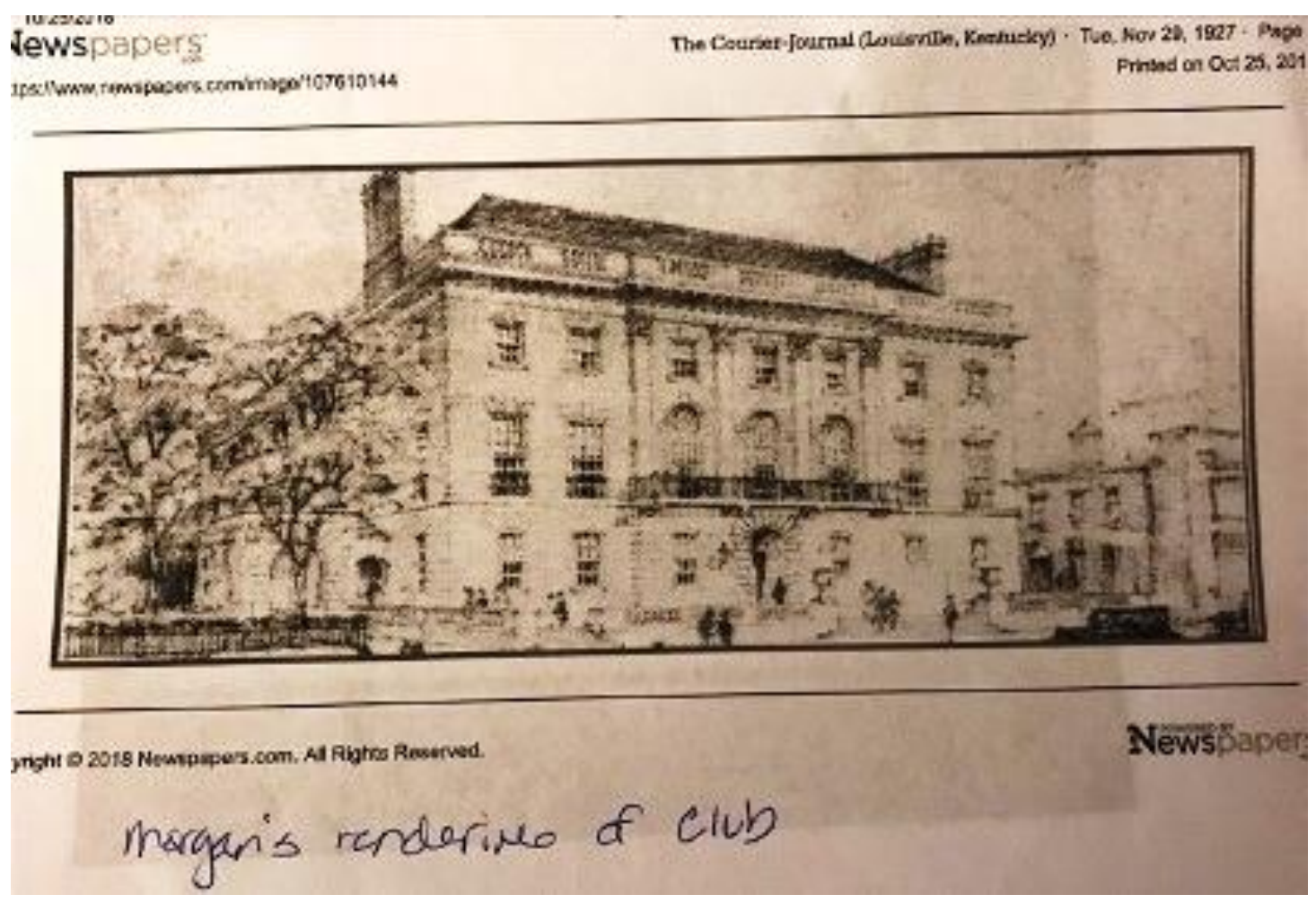

Figure 58. Pendennis Club rendering. No photo credit given. The Courier-Journal, Tuesday, November 29, 1927. www.newspapers.com. 


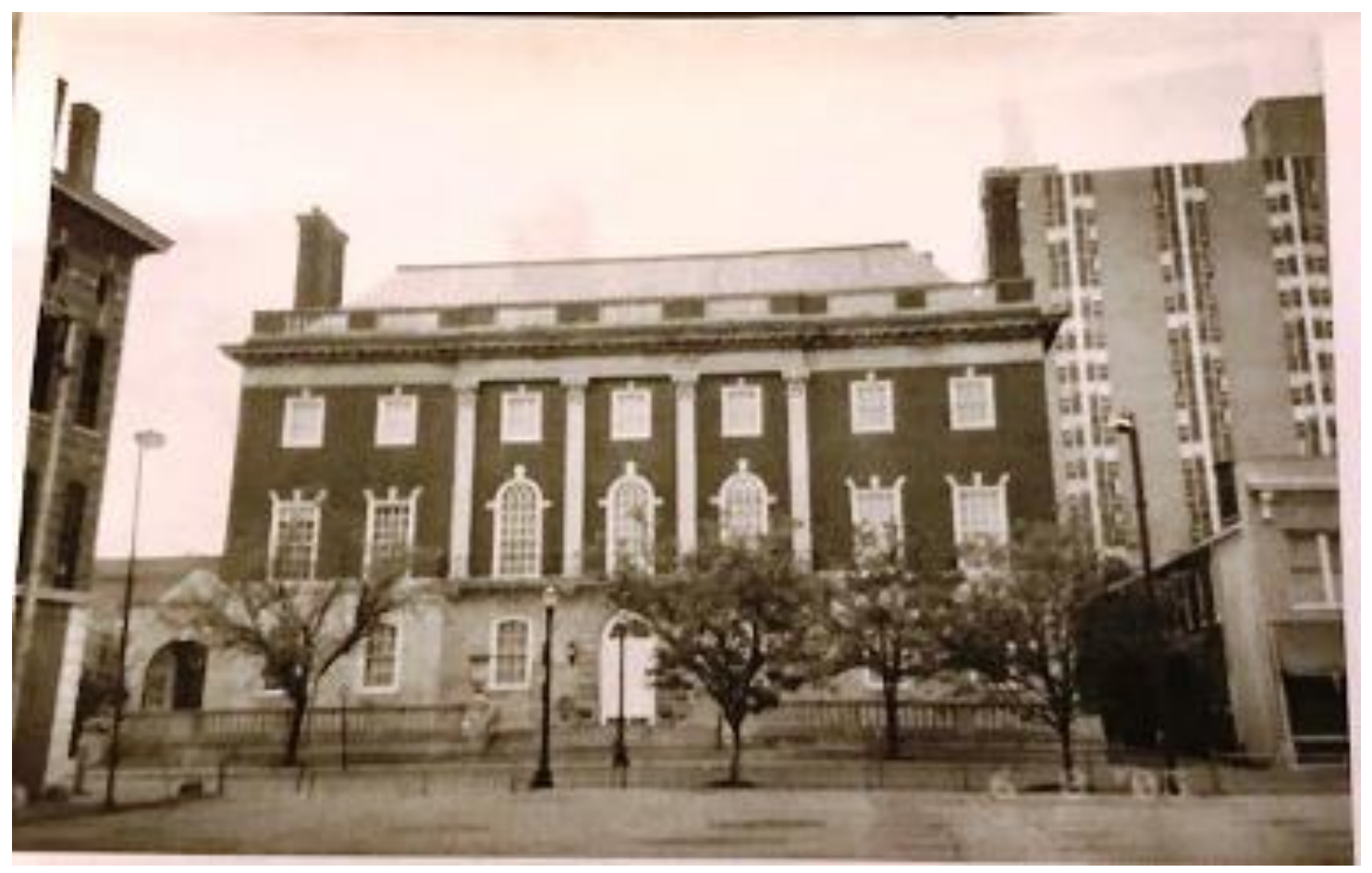

Figure 59. Pendennis Club. No photo credit given. National Register of Historic Places Nomination Form. 


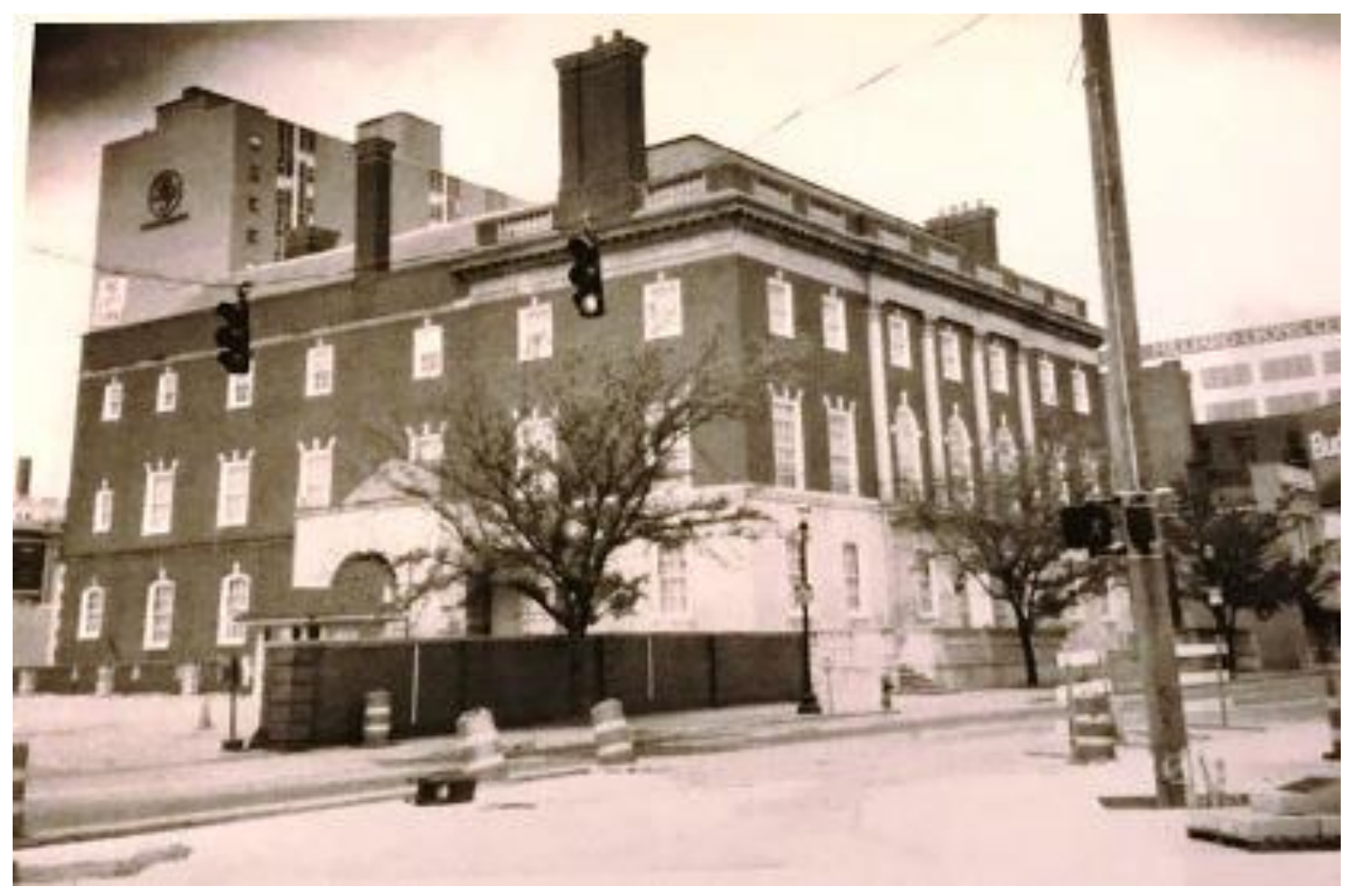

Figure 60. Pendennis Club. No photo credit given. National Register of Historic Places Nomination Form. 


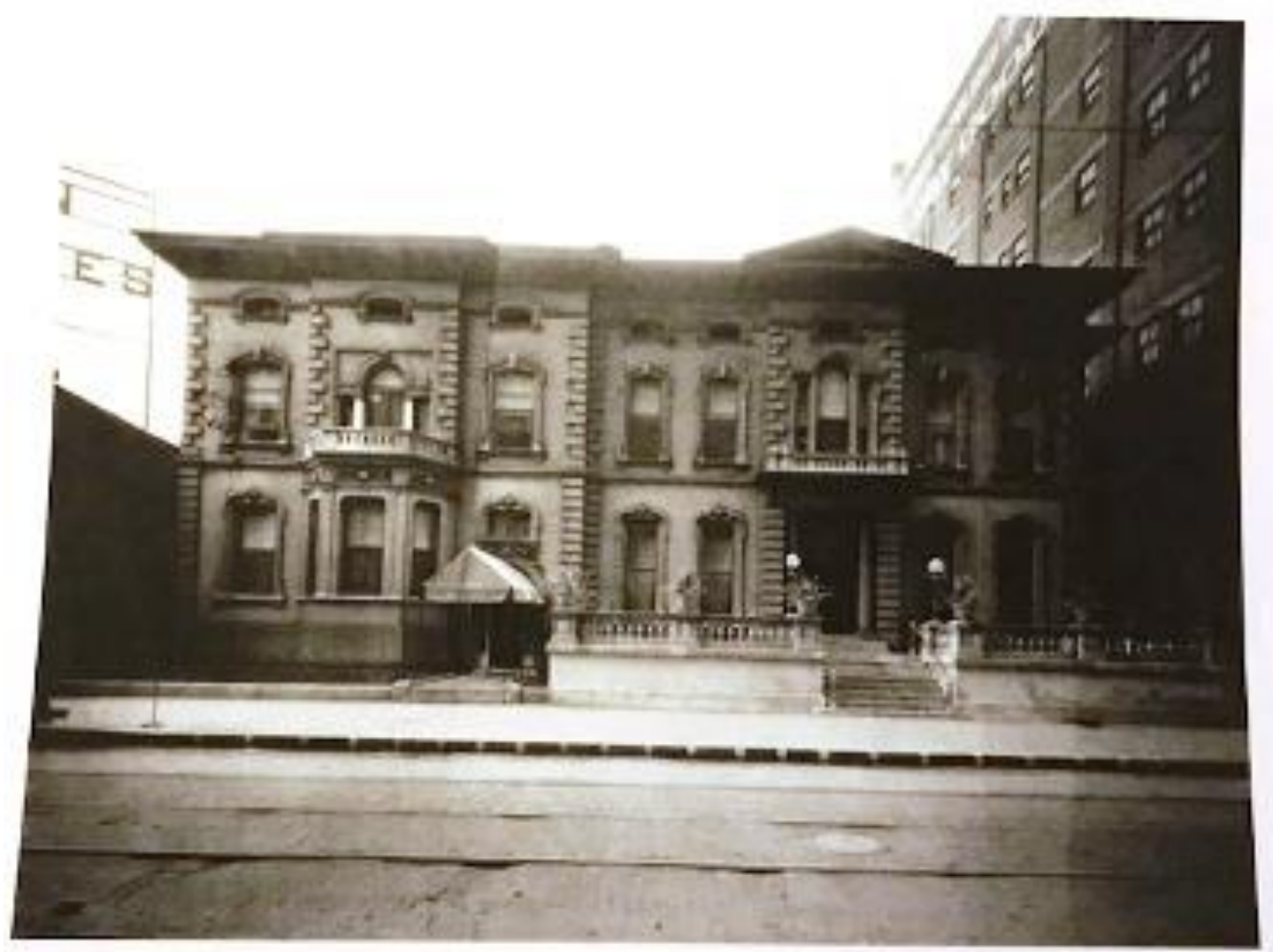

Figure 61. Pendennis Club. Caufield and Shook Collection.

digital.library.louisville.edu/cdm/printview/collection/cs/id/1416/type/

singleitem. 


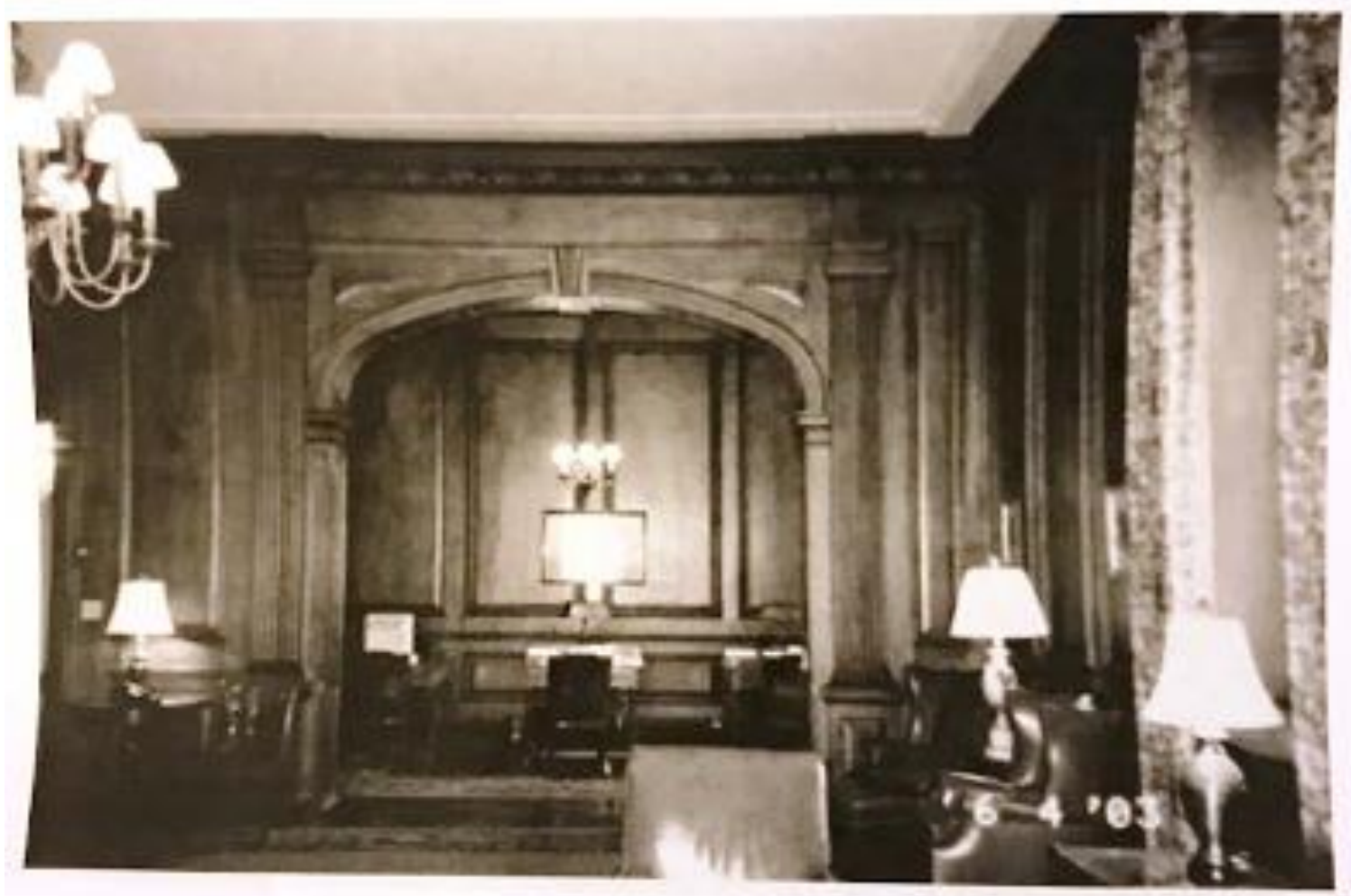

Figure 62. Pendennis Club. No photo credit given. National Register of Historic Places Nomination Form. 


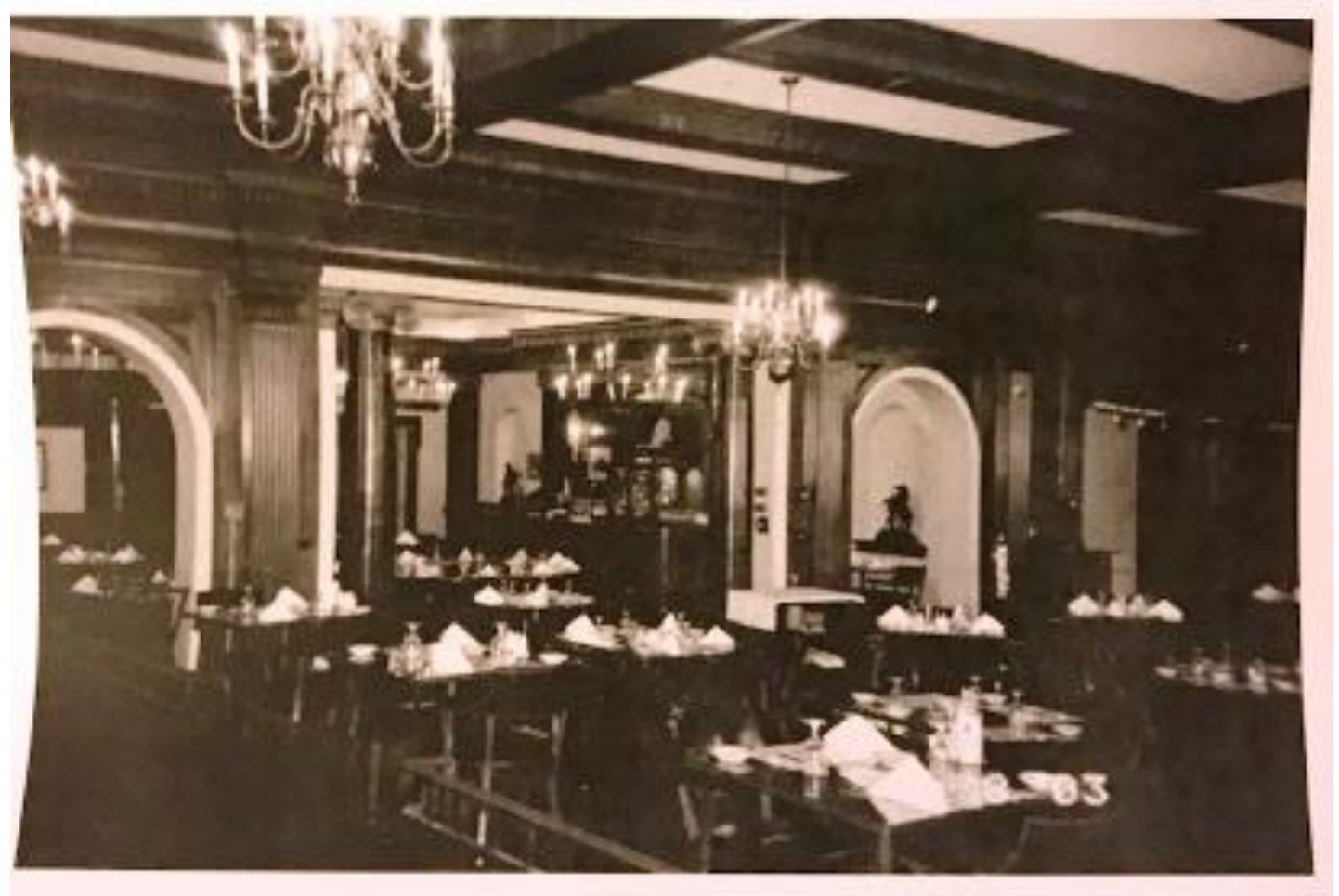

Figure 63. Pendennis Club. No photo credit given. National Register of Historic Places Nomination Form. 


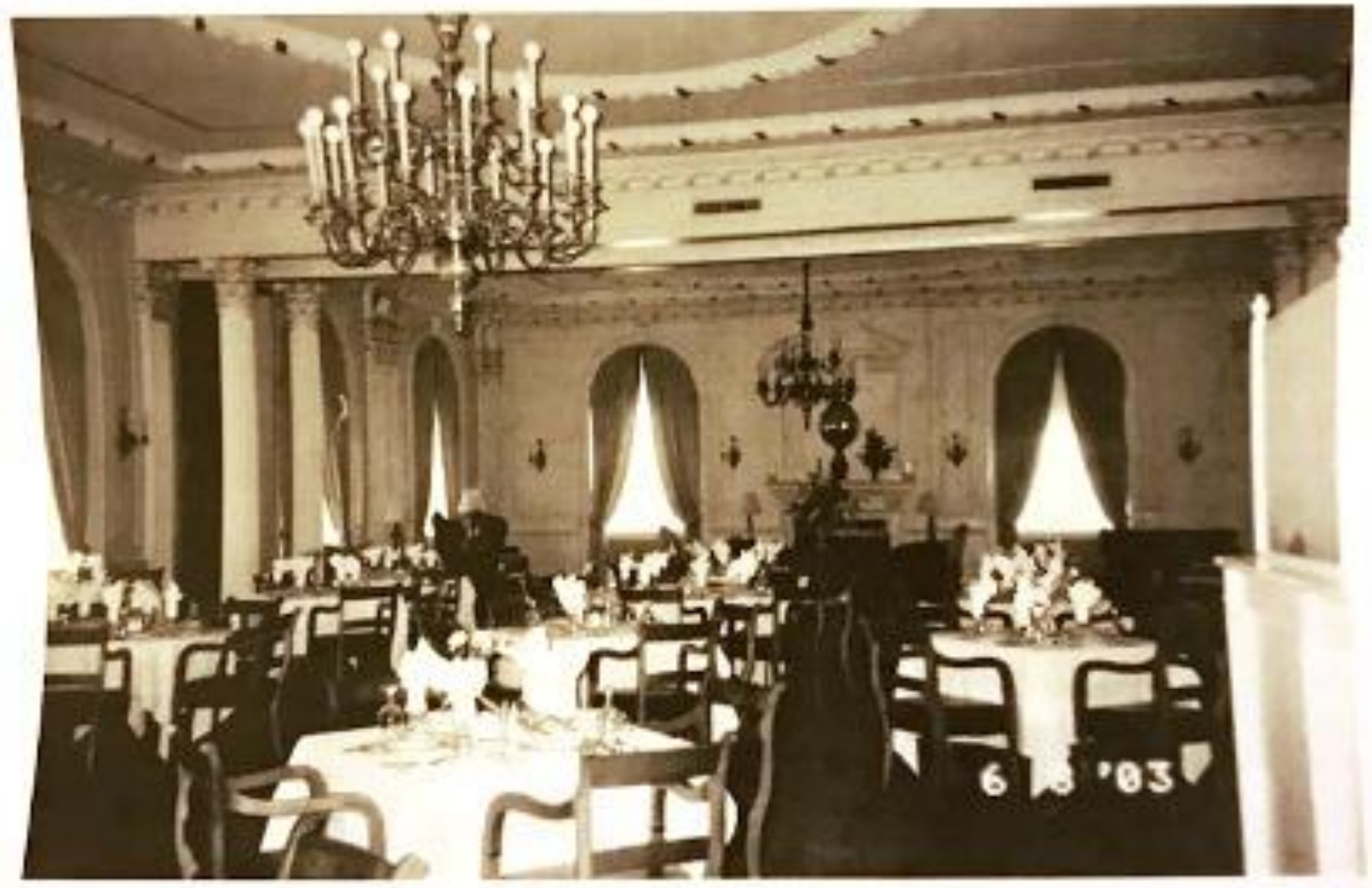

Figure 64. Pendennis Club. No photo credit given. National Register of Historic Places Nomination Form. 


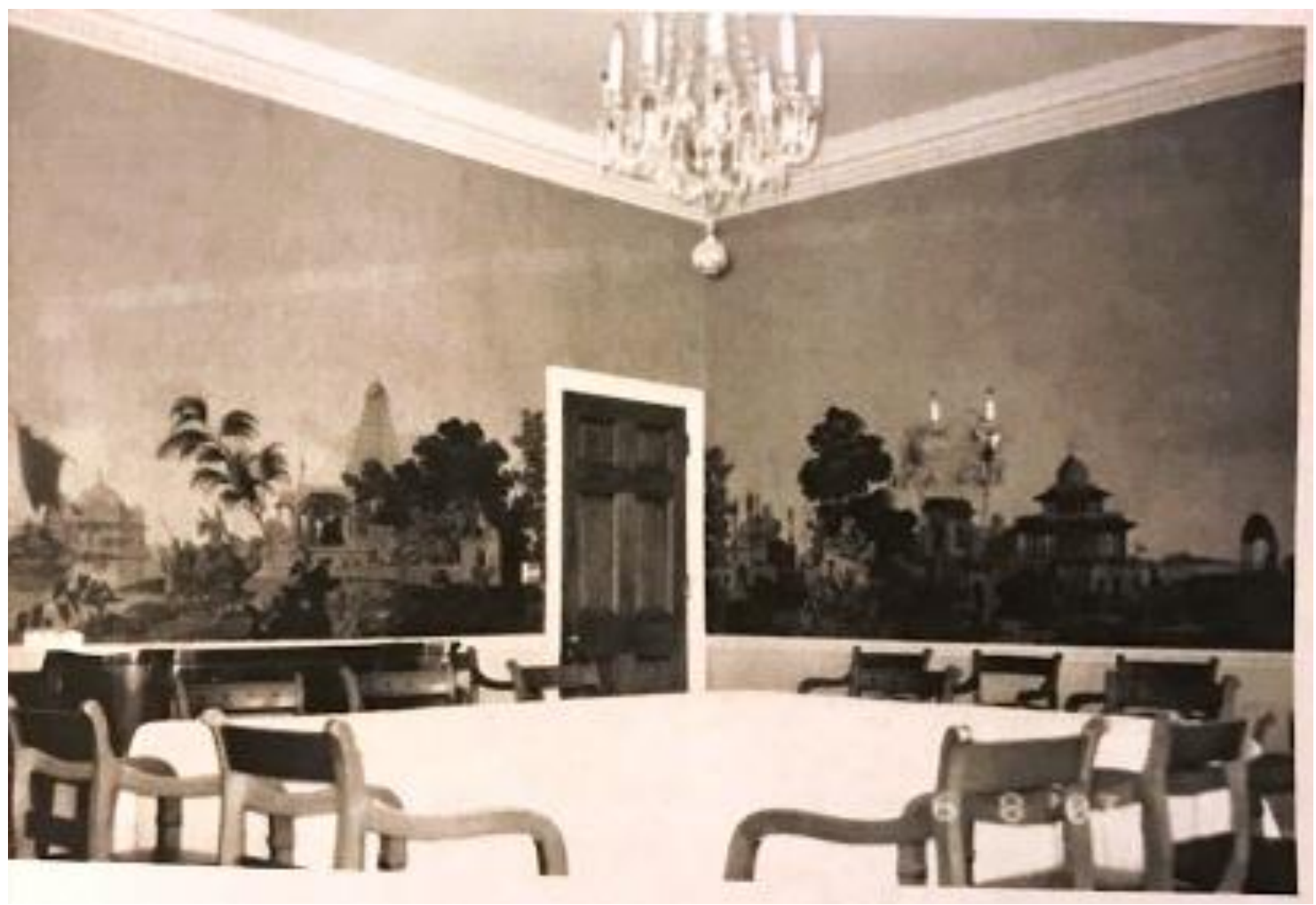

Figure 65. Pendennis Club. No photo credit given. National Register of Historic Places Nomination Form. 


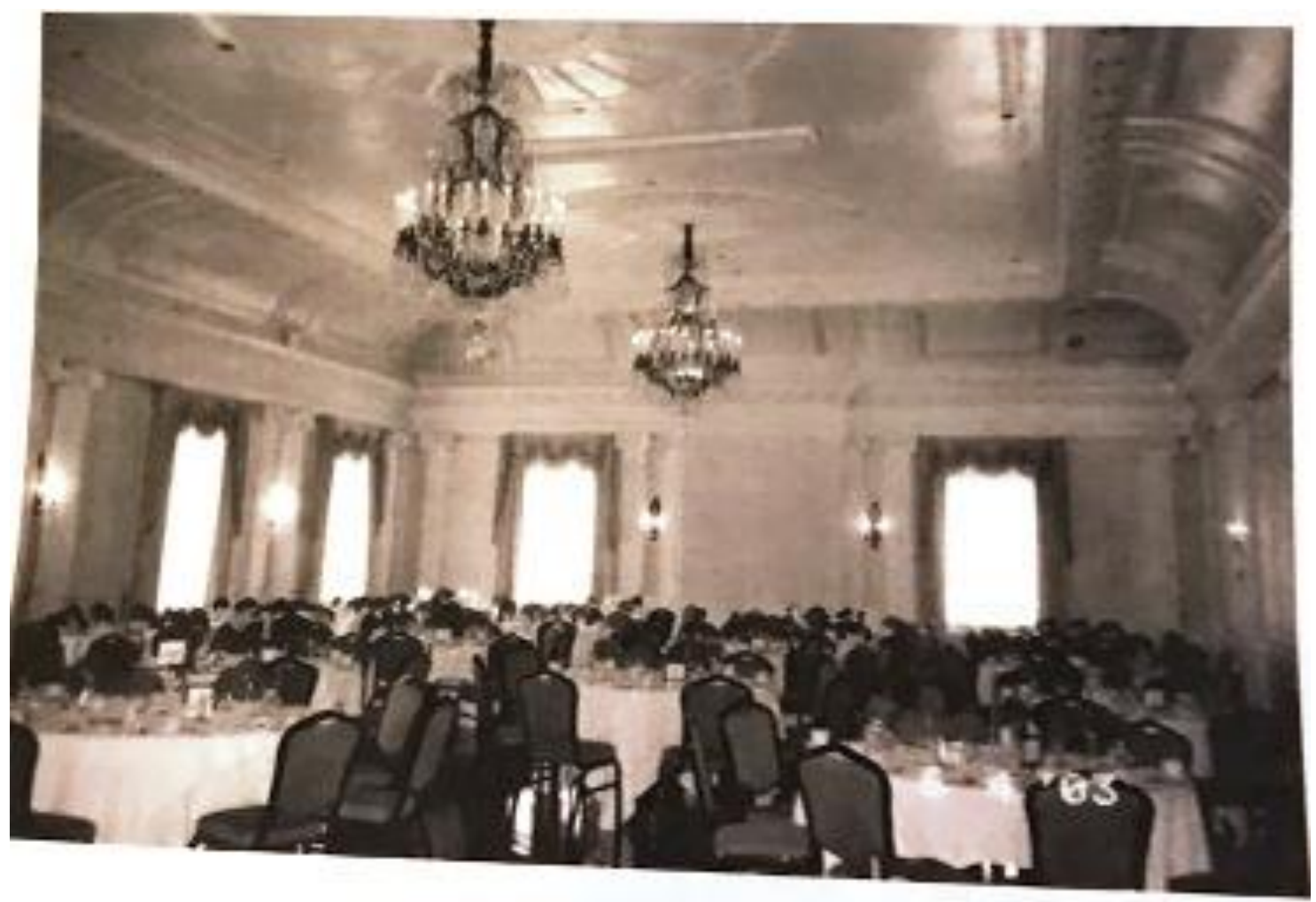

Figure 66. Pendennis Club. No photo credit given. National Register of Historic Places Nomination Form. 


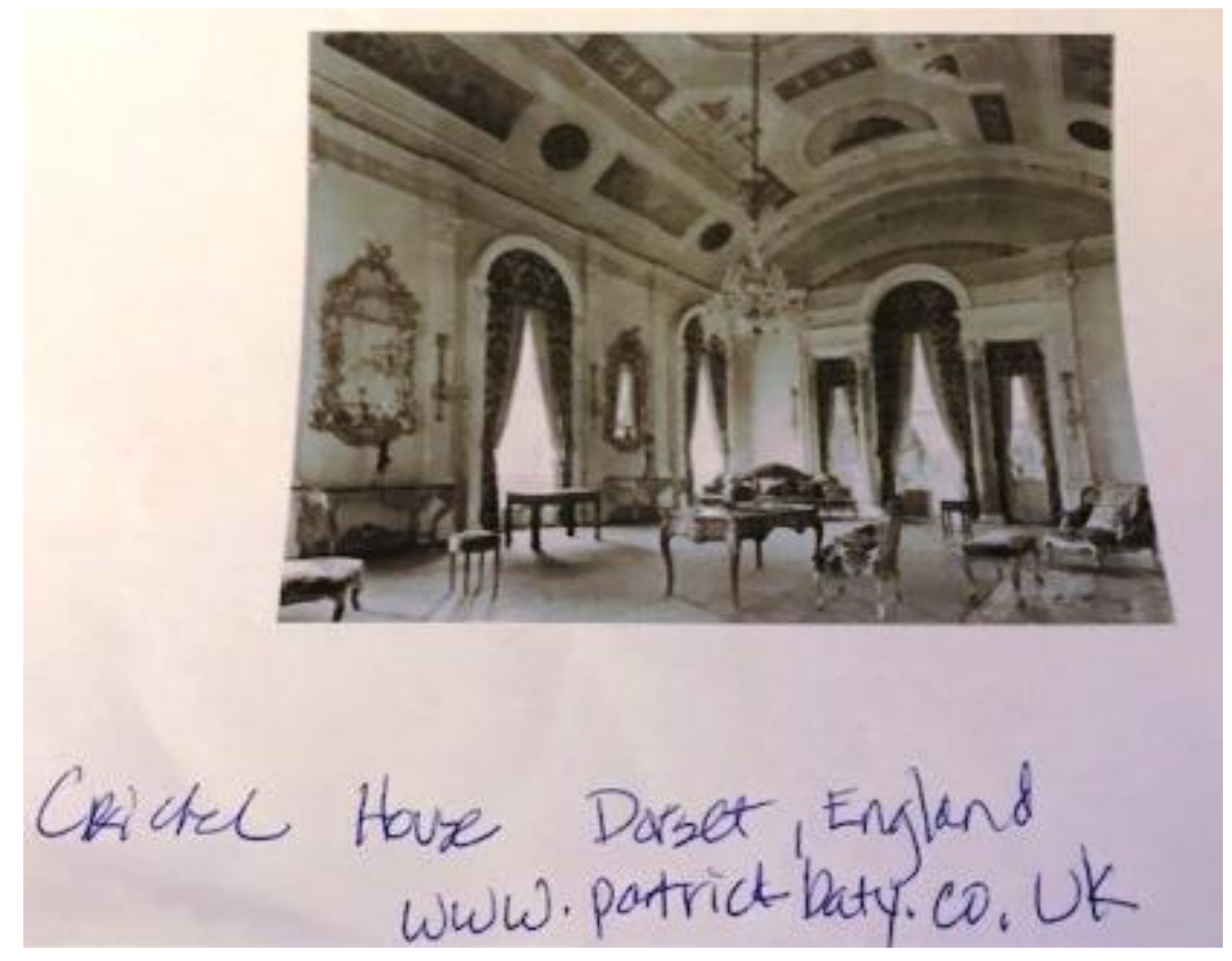

Figure 67. Crichel House. Patrick Baty. www.patrickbatyco.UK. 


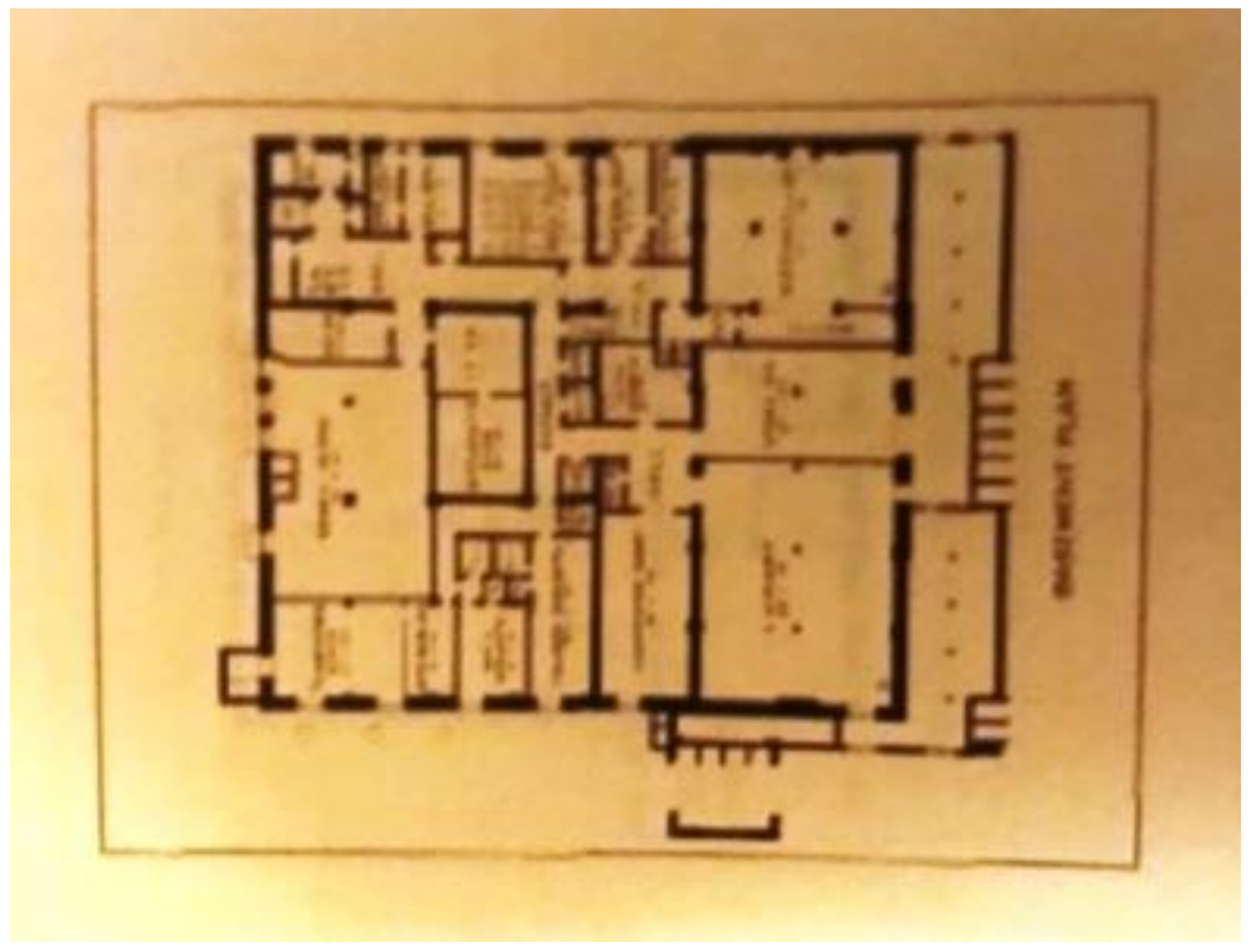

Figure 68. Pendennis Club Floorplan. Kentucky Historical Society. 


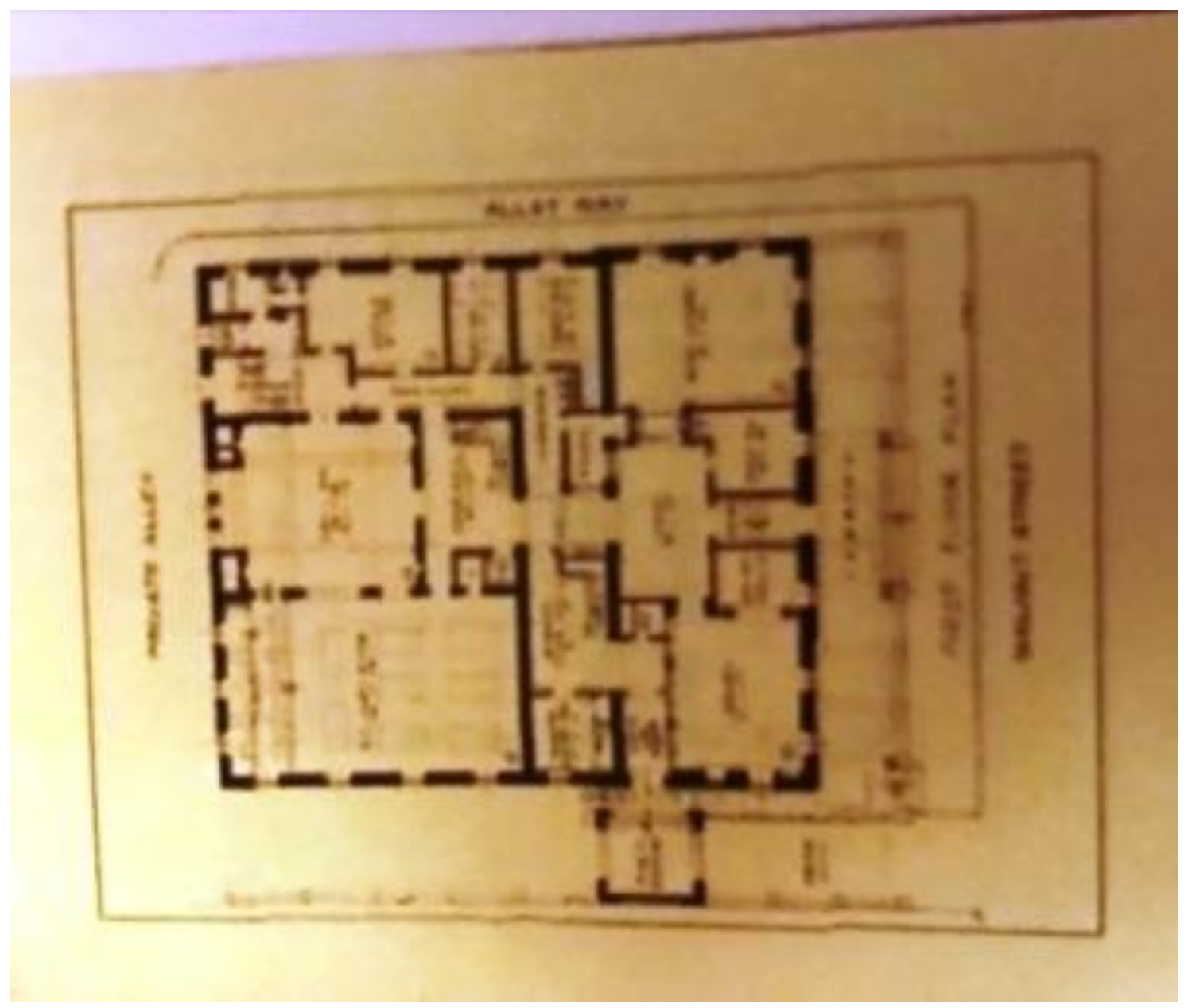

Figure 69. Pendennis Club Floorplan. Kentucky Historical Society. 


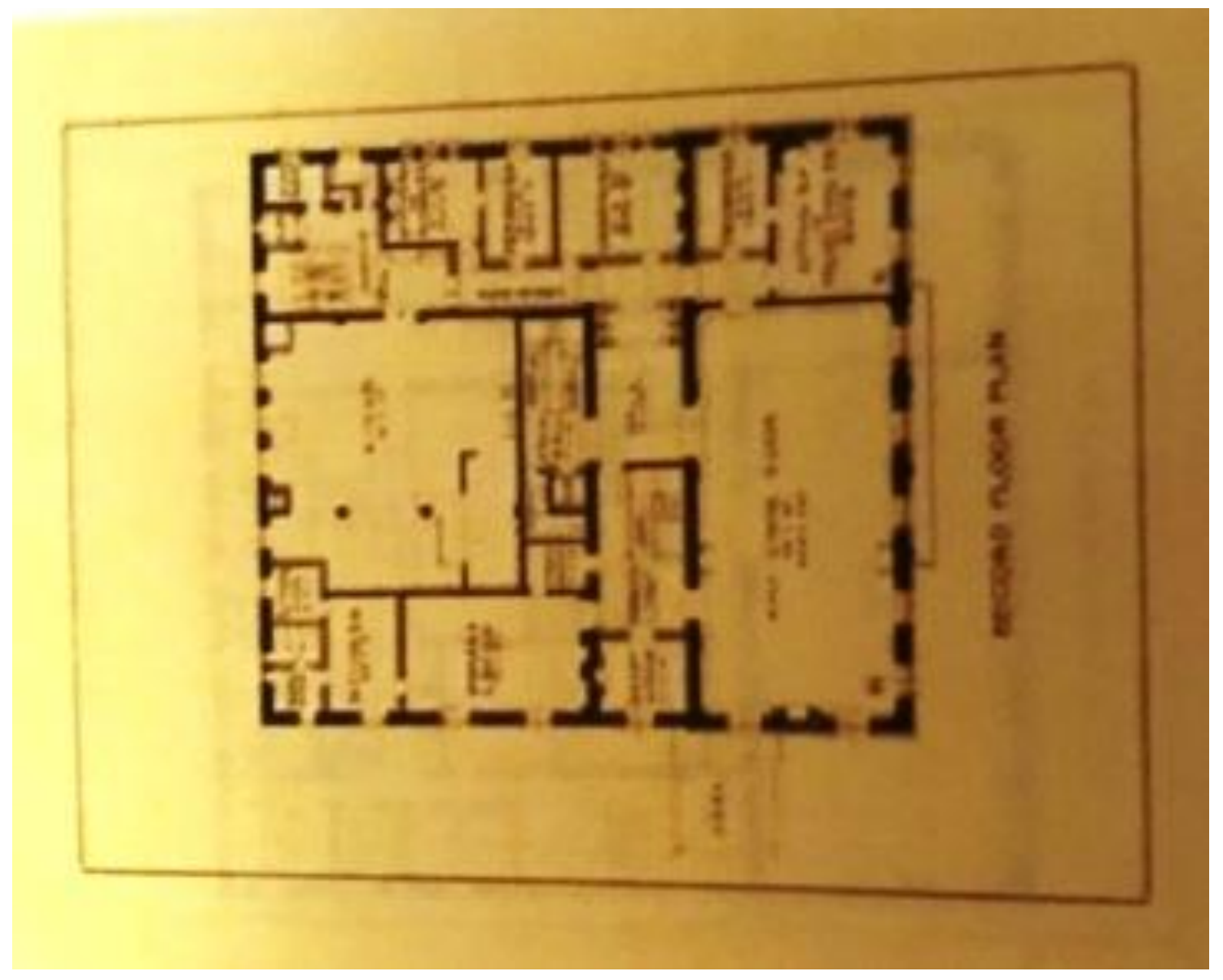

Figure 70. Pendennis Club Floorplan. Kentucky Historical Society. 


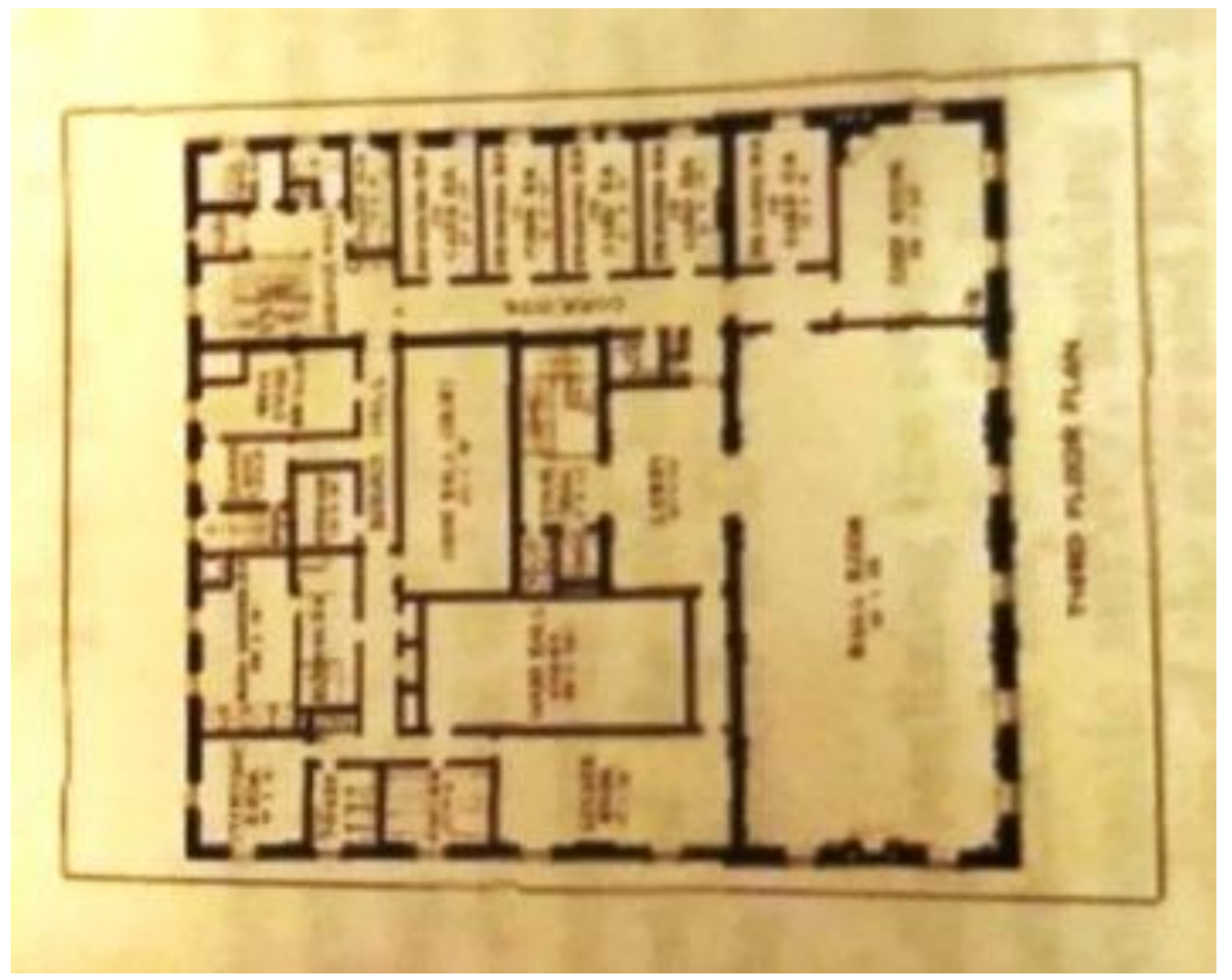

Figure 71. Pendennis Club Floorplan. Kentucky Historical Society. 


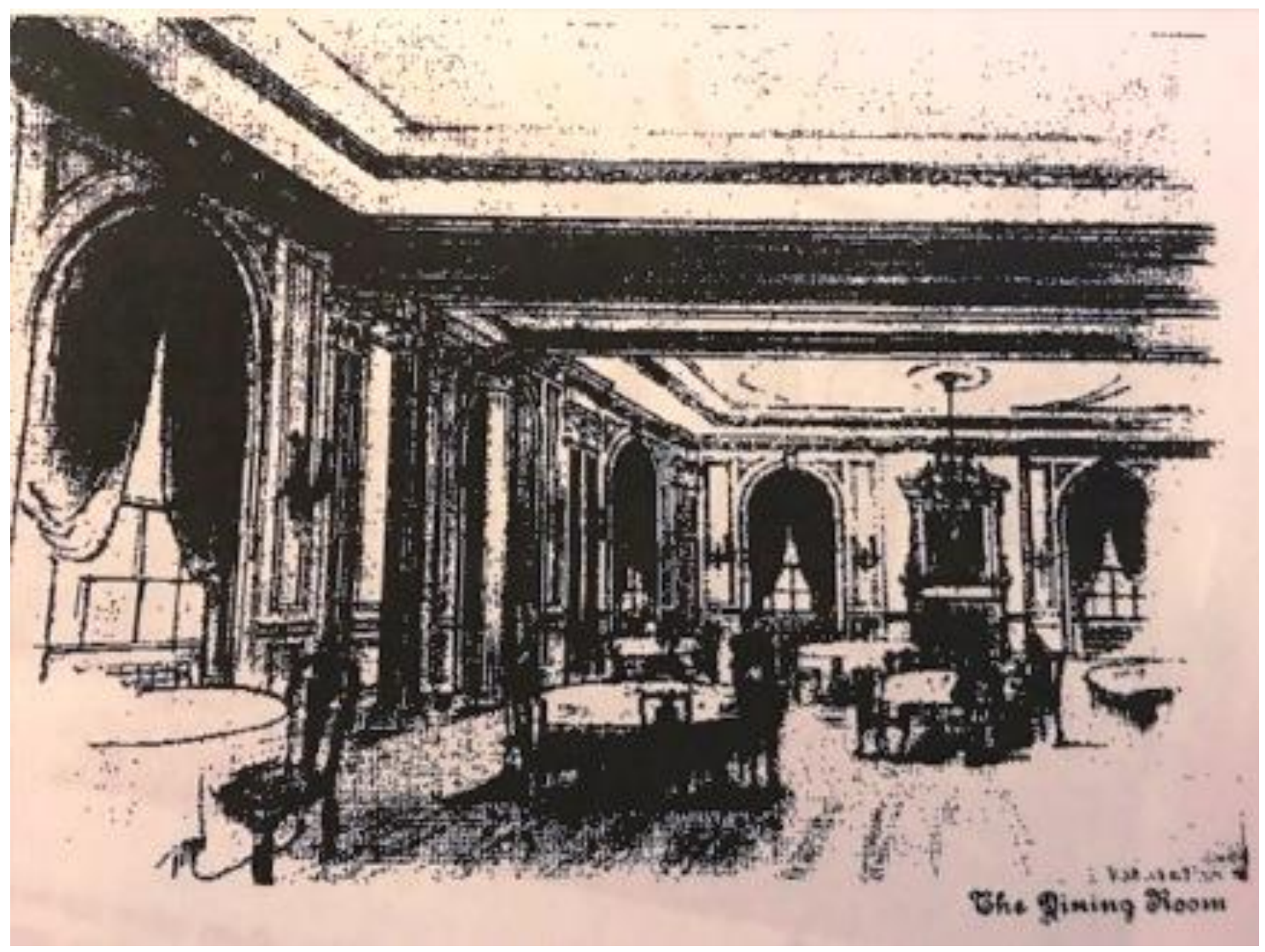

Figure 72. Pendennis Club Rendering. Kentucky Historical Society. 


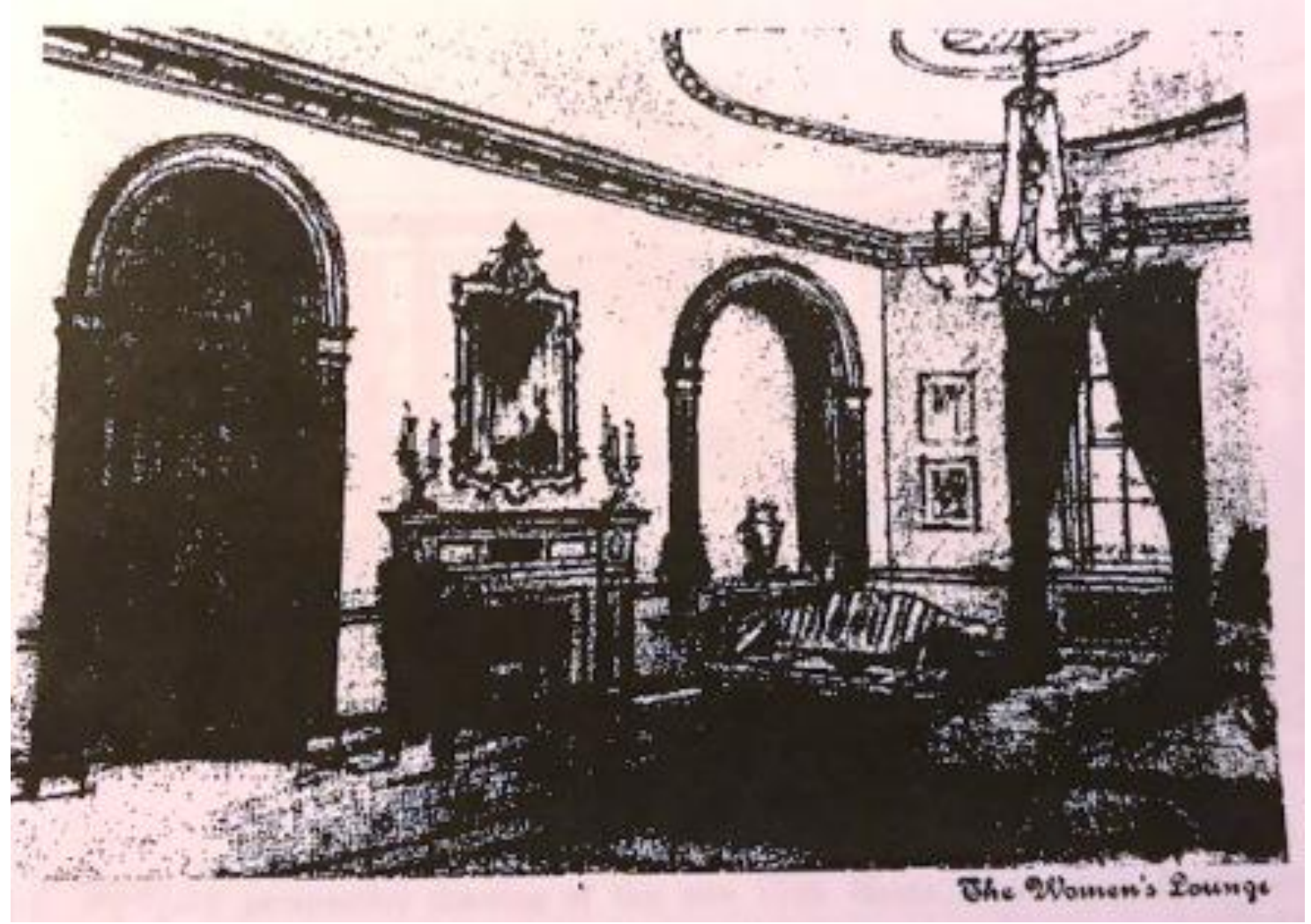

Figure 73. Pendennis Club Rendering. Kentucky Historical Society. 


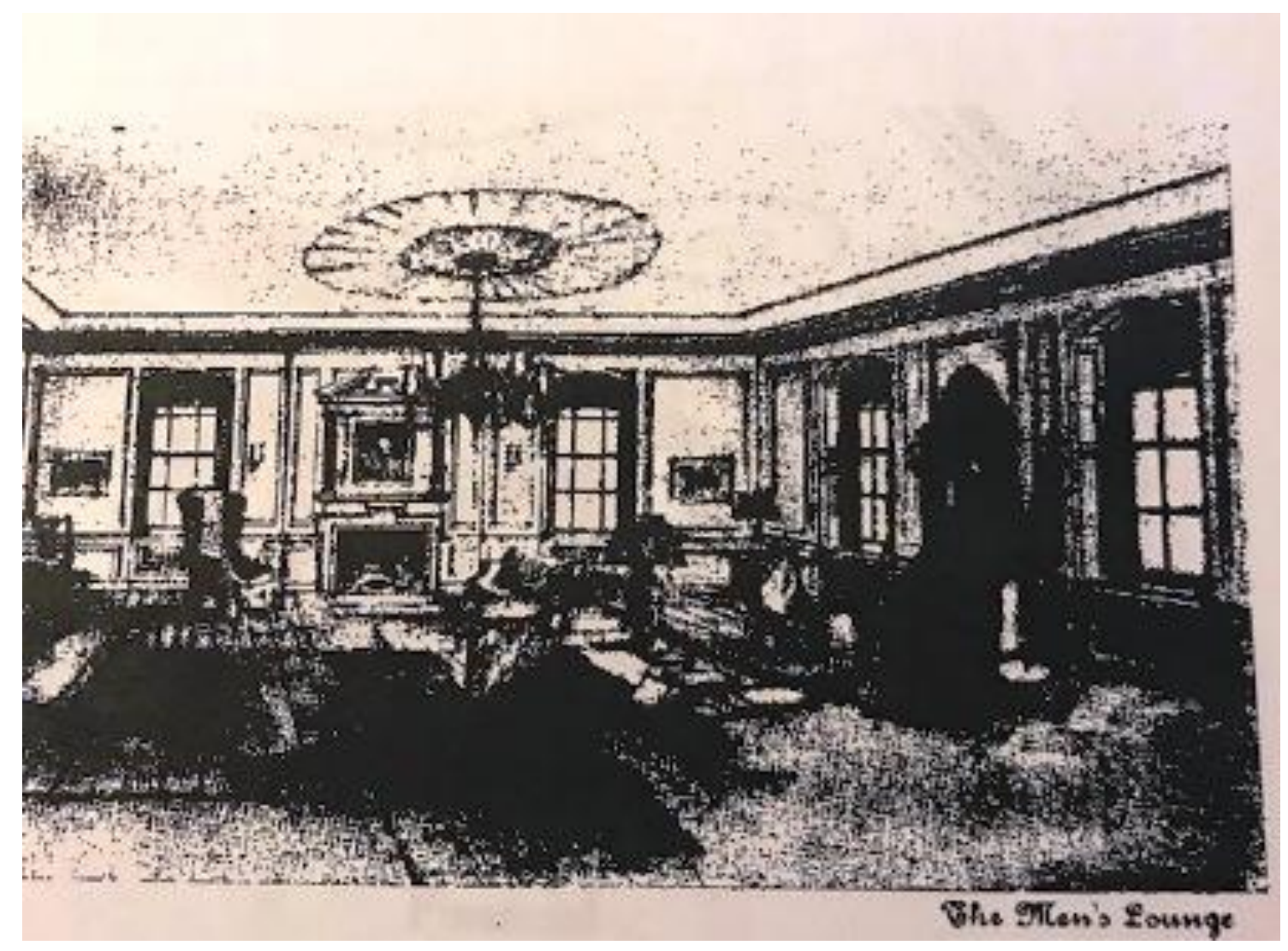

Figure 74. Pendennis Club Rendering. Kentucky Historical Society. 


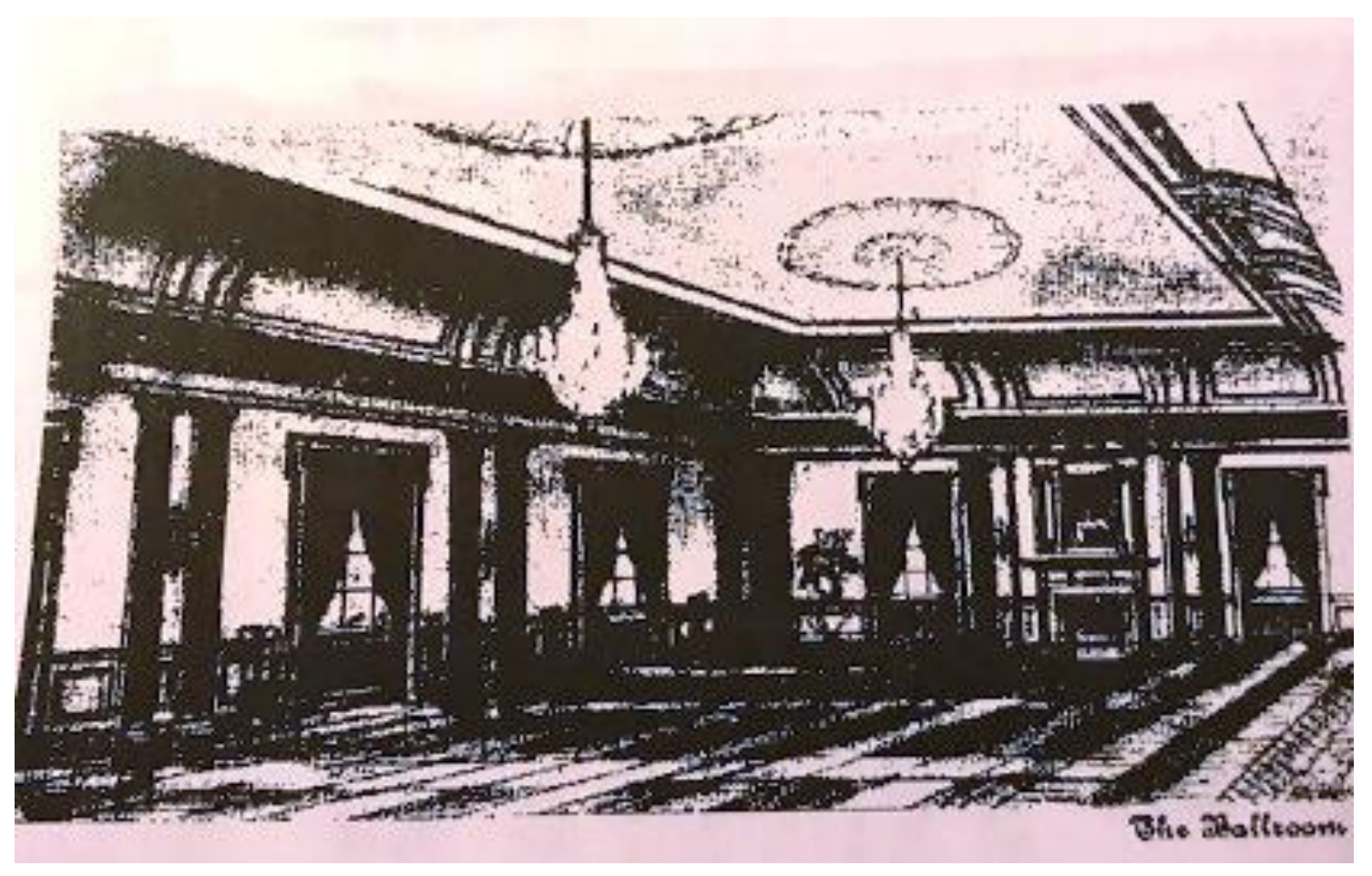

Figure 75. Pendennis Club Rendering. Kentucky Historical Society. 


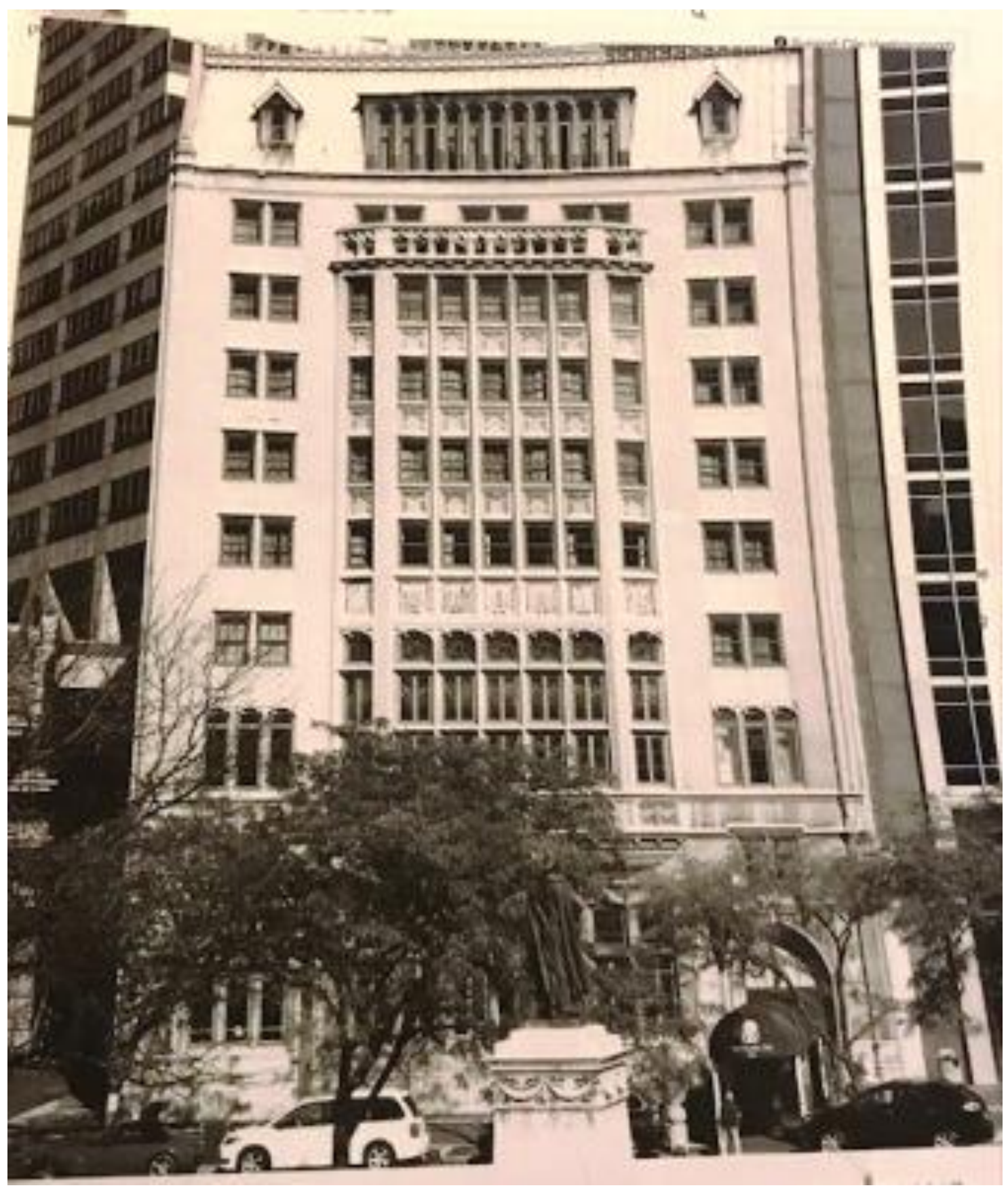

Figure 76. Columbia Club. Steve Tinker. www.theclio.com/web/entry?id=11119. 


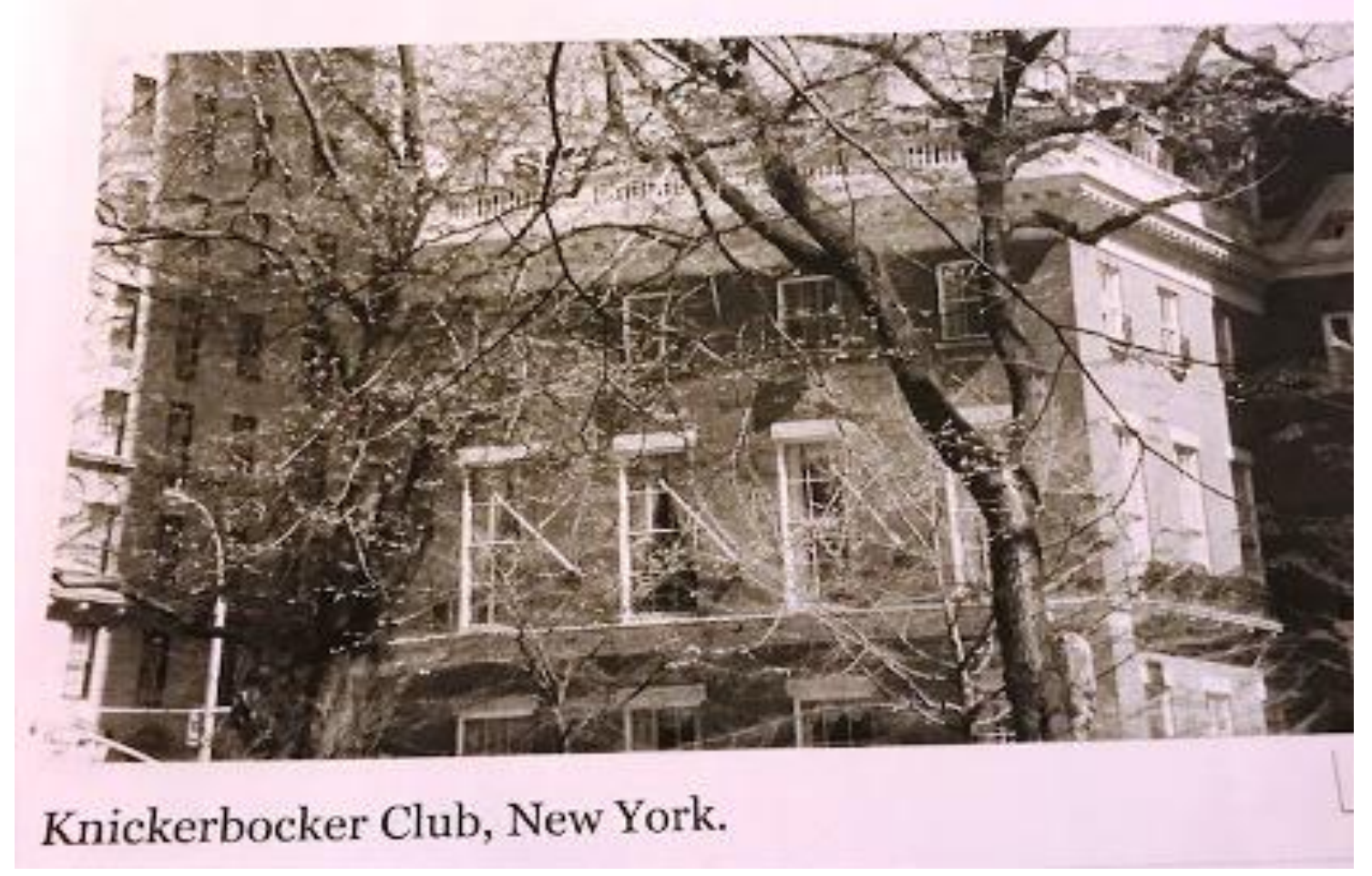

Figure 77. Knickerbocker Club. Philippe Cendron.

en.wikipedia.org.wiki/

Knickerbocker_Club\#/media/File: Knickerbocker_Club.JPG. 


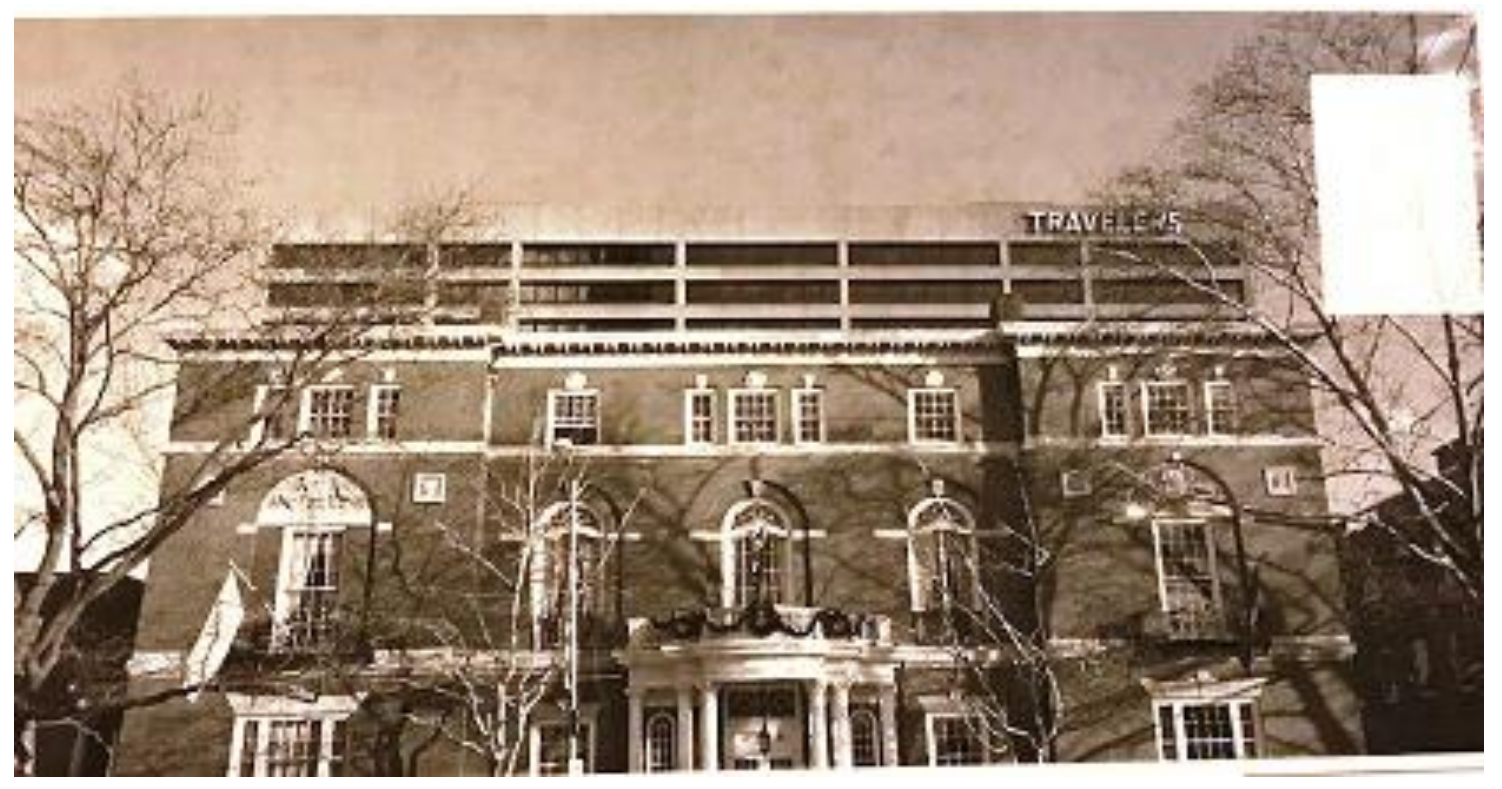

Figure 78. Hartford Club. John Phelan.

en.wikipedia.org.wiki/Hartford_Club

\1"/media/File:Hartford_Club,_Hartford_CT.jpg" 


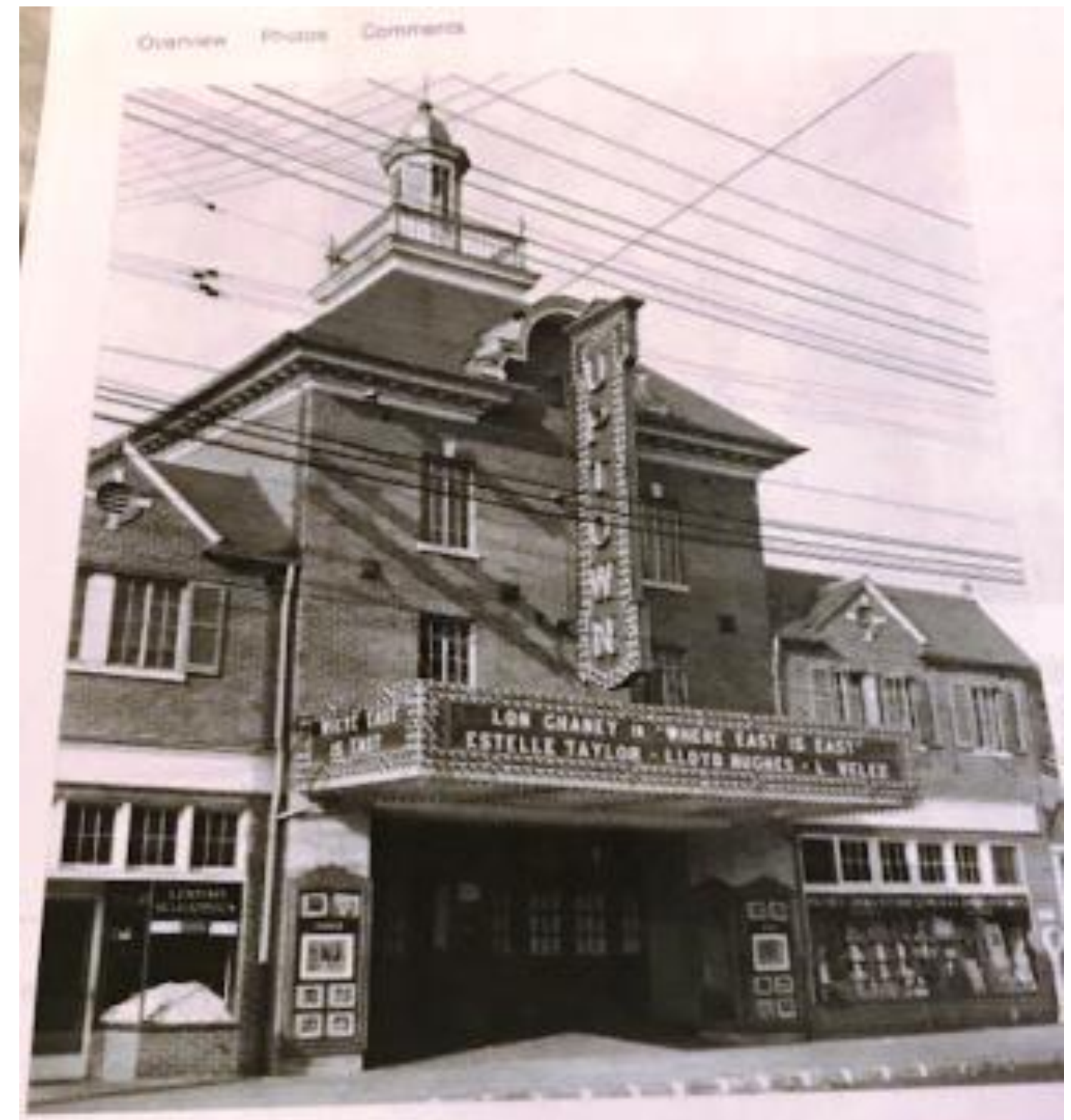

Located in the Schuster Building at the intersection of Eastern Parkwa leighborhood, the Uptown Theatre opened on April 8, 1928.

The Uptown Theatre was Louisville, Kentucky's first theatre to open e oth silent and sound films.

Figure 79. Schuster Building. No photo credit given. cinematreasures.org/theaters/19378. 


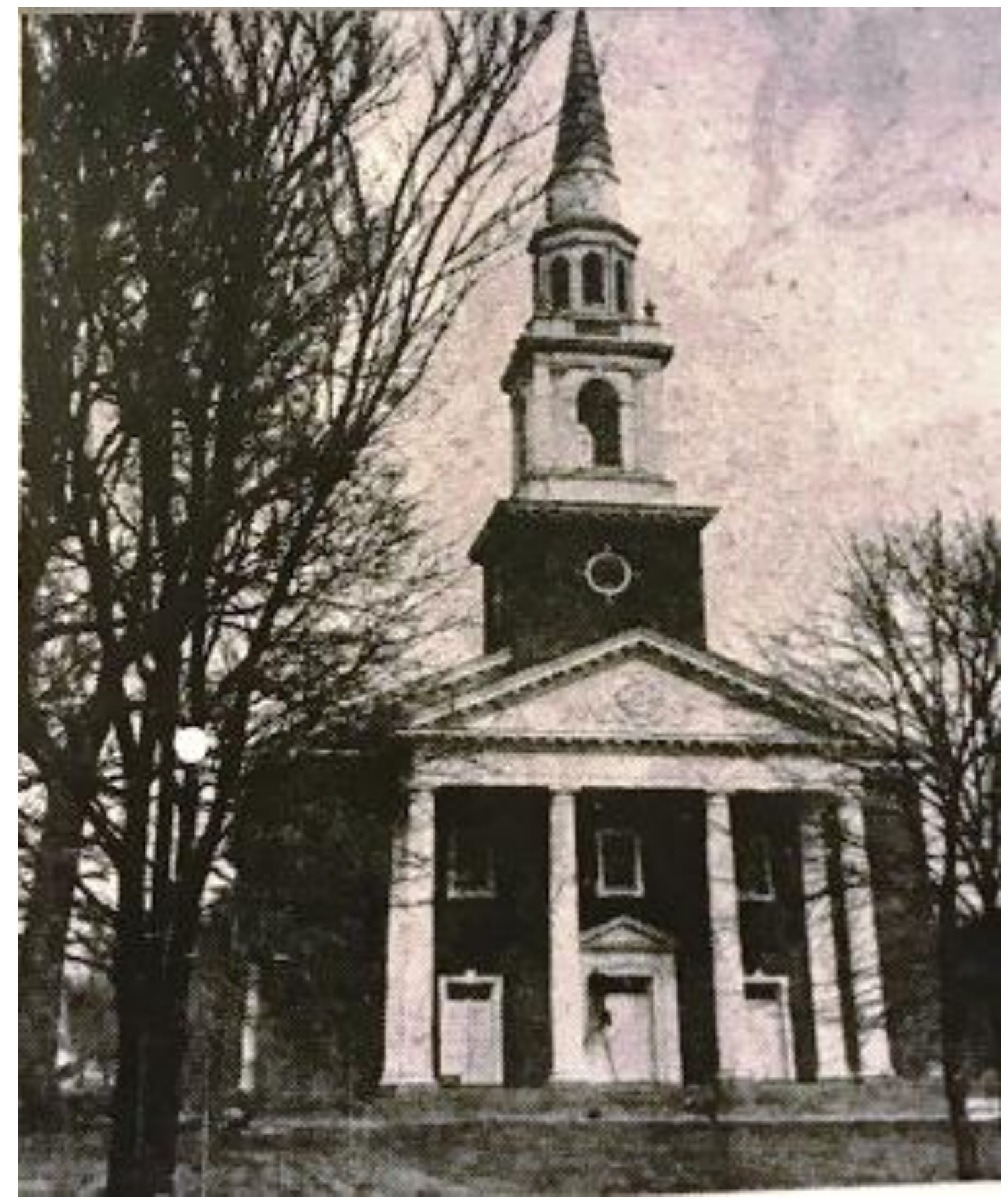

Figure 80. New Alumni Chapel. No photo credit given. The Courier-Journal. Sunday, March 19, 1950. www.newspapers.com. 


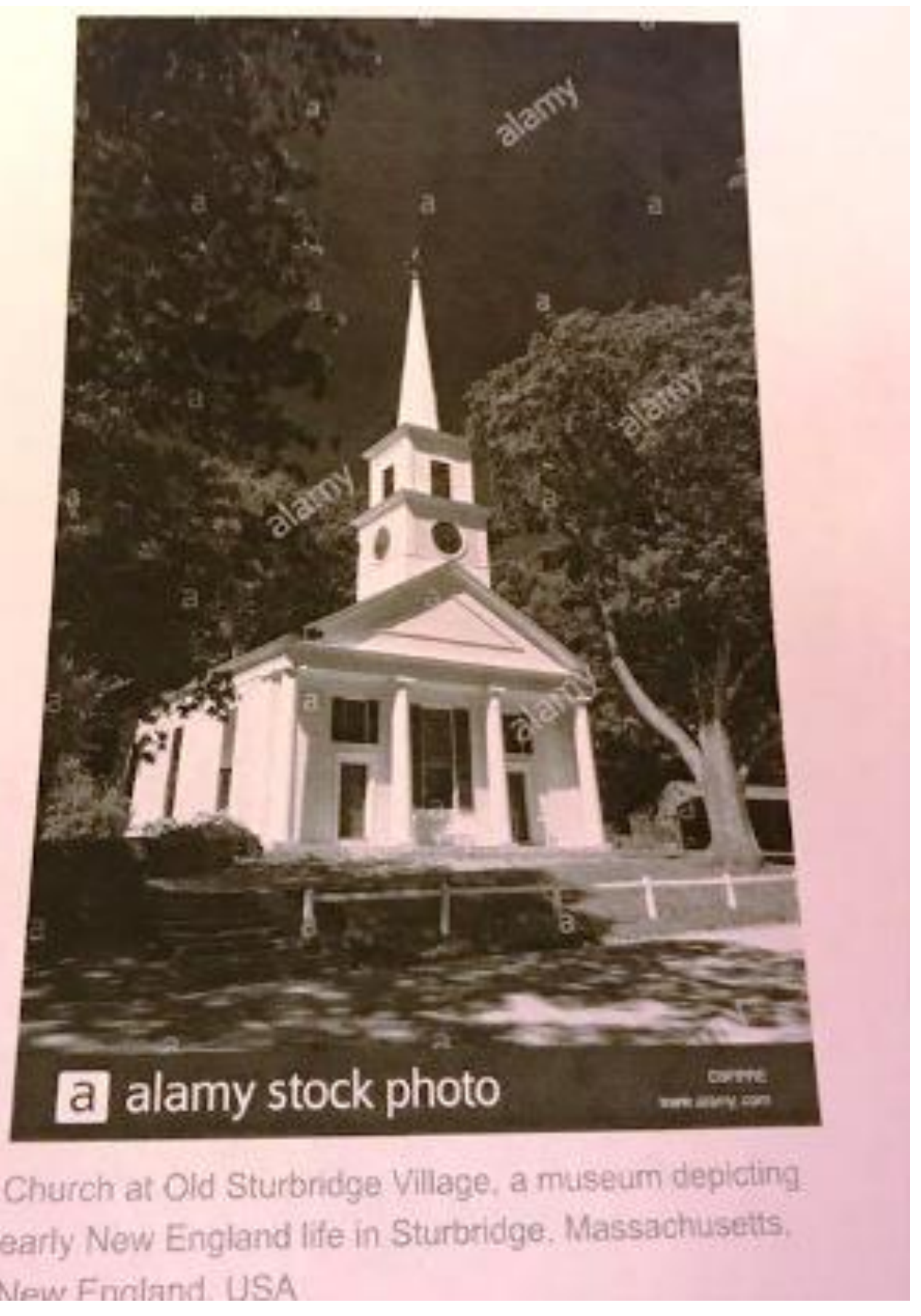

Figure 81. Church at Old Sturbridge Village. Robert Harding/Alamy Stock Photo. www.alamy.com. 


\section{CURRICULUM VITA}

NAME: $\quad$ Lisa Grace Carpenter

ADDRESS: 11929 Creel Lodge Drive

Louisville, KY 40223

EDUCATION

\& TRAINING: $\quad$ Ph.D., Doctor of Philosophy in Art History

University of Louisville

2018

M.A.T., Art P-12

University of the Cumberlands

2013

M.A., Art History

University of Louisville

1996

B.A., Housing and Interior Design

University of Kentucky

1992

AWARDS: Frederic Morgan Award, University of Louisville, Louisville, KY 2016-2018

Kappa Delta Phi honorary fraternity, University of the Cumberlands, Williamsburg, KY

2013

Don Payton Award, Allen R. Hite Art Institute, University of Louisville, Louisville, KY

1997

Dean's Citation for Outstanding Graduate Student, College of Arts and Sciences, University of Louisville, Louisville, KY 1997 
Phi Kappa Phi honorary fraternity, University of Louisville, Louisville, KY

1997

Who's Who in Interior Designers, nominated 1995

Phi Upsilon Omicron honorary fraternity, University of Kentucky, Lexington, $\mathrm{KY}$ 1990

PROFESSIONAL SOCIETIES:

American Society of Interior Designers

Louisville Historic League

Alpha Delta Pi Alumnae

Louisville Visual Art Association

PUBLICATION: Carpenter, Lisa. "James J. Gaffney." Kleber, J. (2000). Encyclopedia of Louisville. Lexington, KY: UP of Kentucky 